\title{
LAS TRANSFORMACIONES DE LA EDUCACIÓN
}

De la tradición a la modernidad hasta la incertidumbre actual

José F. Durán VÁzQuez

Eduardo Duque

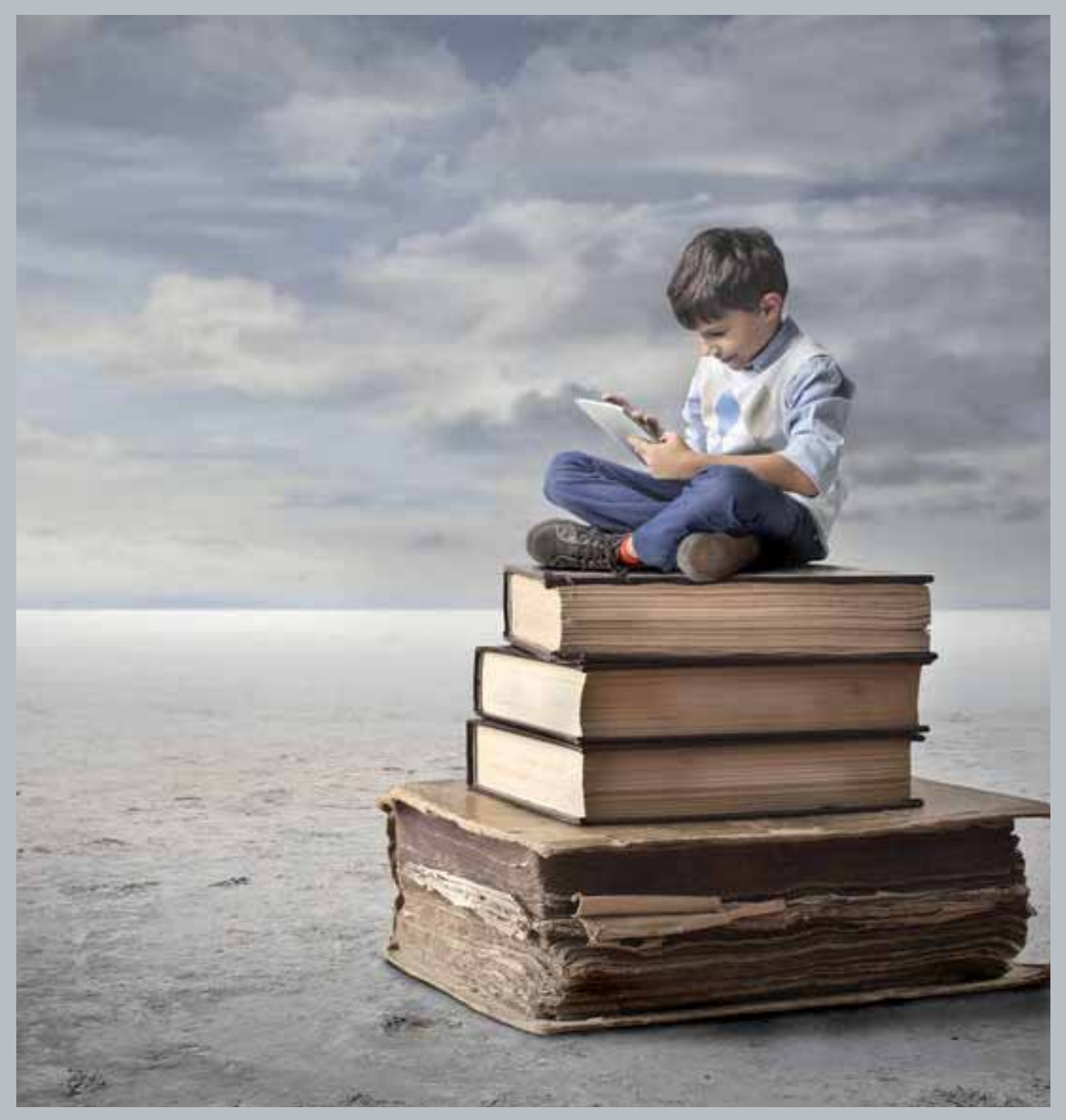





\section{LAS TRANSFORMACIONES DE LA EDUCACIÓN}

De la tradición a la modernidad hasta la incertidumbre actual 



\title{
LAS TRANSFORMACIONES DE LA EDUCACIÓN
}

\author{
De la tradición a la modernidad
}

hasta la incertidumbre actual

José F. DURÁn VÁzQUEZ

Eduardo Duque 
No está permitida la reproducción total o parcial de este libro, ni su incorporación a un sistema informático, ni su transmisión en cualquier forma o por cualquier medio, sea este electrónico, mecánico, por fotocopia, por grabación u otros métodos, sin el permiso previo y por escrito del editor. La infracción de los derechos mencionados puede ser constitutiva de delito contra la propiedad intelectual (art. $270 \mathrm{y}$ siguientes del Código Penal).

Diríjase a Cedro (Centro Español de Derechos Reprográficos) si necesita fotocopiar o escanear algún fragmento de esta obra. Puede contactar con Cedro a través de la web www.conlicencia.com o por teléfono en el 917021970/932720407

Este libro ha sido sometido a evaluación por parte de nuestro Consejo Editorial Para mayor información, véase $w w w . d y k i n s o n . c o m / q u i e n e s \_s o m o s$

(C) Copyright by

José Francisco Durán Vázquez y Eduardo Duque

Madrid, 2019

Editorial DYKINSON, S.L. Meléndez Valdés, 61 - 28015 Madrid

Teléfono (+34) 915442846 - (+34) 915442869

e-mail:info@dykinson.com

http://www.dykinson.es

http://www.dykinson.com

ISBN: 978-84-1324-285-9

Preimpresión por:

Besing Servicios Gráficos S.L.

e-mail: besingsg@gmail.com 


\section{ÍNDICE}

INTRODUCCIÓN

\section{PARTE I. \\ LA EDUCACIÓN EN EL MUNDO PREMODERNO}

CAPÍTULO I. EL MUNDO CLÁSICO: GRECIA Y ROMA ………………………..... 17

1.1. LOS CONTENIDOS Y LOS FINES DE LA EDUCACIÓN …………………...... 17

1.2. LOS MODELOS EDUCATIVOS Y LOS MODOS DE TRANSMISIÓN ......... 19

1.3. LA CONDICIÓN DE LA ENSEÑANZA ESCOLAR ............................................. 22

CAPÍTULO II. LA EDUCACIÓN EN EL MEDIEVO_................................................ 25

2.1. ENTRE LA TRADICIÓN CLÁSICA Y LA CRISTIANA ………………………... 25

2.2. LAS CONCEPCIONES DE LA INFANCIA Y DE LA JUVENTUD.................. 26

2.3. LA EDAD ADULTA COMO MODELO Y COMO META …………………...... 30

2.4. LAS PERSONAS, LOS MODOS Y LOS CONTENIDOS DE LA EDUCACIÓN.................................................................................................. 32

2.5. LA DEBILIDAD DE LA ENSEÑANZA ESCOLAR ............................................ 35

CONCLUSIÓN ……………………………………………………………..... 37

CAPÍTULO III. LA EDUCACIÓN EN LA SOCIEDAD

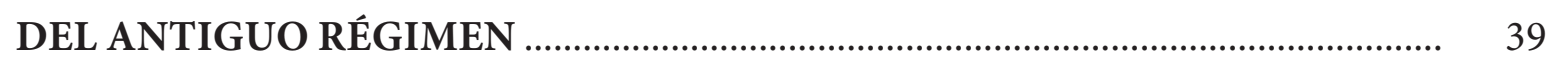

3.1. CORTESÍA Y CIVILIDAD: LA ENSEÑANZA DE LAS BUENAS COSTUMBRES Y DE LAS BUENAS LETRAS .................................................... 39

3.2. INFANCIA, JUVENTUD Y EDAD ADULTA ……………………………...... 42

3.3. LA INFANCIA Y LA JUVENTUD ESCOLARIZADAS ..................................... 46

CONCLUSIÓN ............................................................................................... 51 
CONCLUSIÓN PARTE I. LA EDUCACIÓN EN LA SOCIEDAD

PREINDUSTRIAL. TRADICIÓN, CONVIVENCIA, TRANSMISIÓN.

PARTE II.

GÉNESIS, TRANSFORMACIÓN Y CRÍTICA DEL

PENSAMIENTO EDUCATIVO MODERNO

CAPÍTULO I. LA EDUCACIÓN DEL SUJETO MODERNO.

GENEALOGÍA DE UN DISCURSO

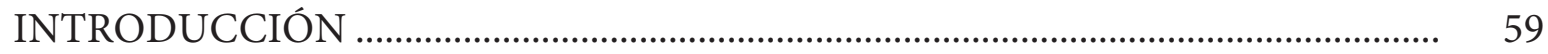

1.1. EL CONTEXTO DE LA NUEVA IDEOLOGÍA................................................... 60

1.2. LA EDUCACIÓN DEL SUJETO MODERNO ....................................................... 64

1.2.1. La civilidad humanista .............................................................................. 64

1.2.2. $\quad$ La pedagogía de la Reforma .................................................................... 67

1.2.3. El pensamiento educativo de John Locke. Entre tradición y modernidad ...................................................................................... 71

1.2.4. Rousseau: la educación por la naturaleza............................................ 76

1.2.5. Socialismo, marxismo y anarquismo. La educación a través

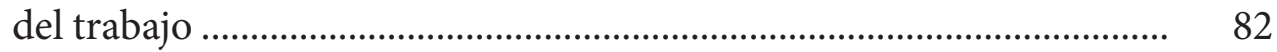

1.2.6. La educación en la sociedad democrática e industrial: el programa educativo de Emile Durkheim y John Dewey ....................................... $\quad 89$

CONCLUSIÓN

CAPÍTULO II. LA MODERNIDAD CONTRA SÍ MISMA:

LA CRÍTICA DEL PROGRAMA EDUCATIVO MODERNO............................... 103

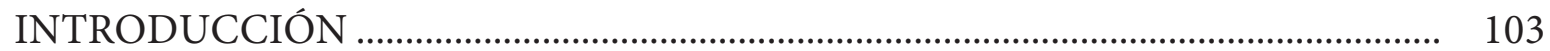

2.1. SUMMERHILL: LA EDUCACIÓN CENTRADA EN LA INFANCIA ............. 104

2.2. IVAN ILLICH: EDUCACIÓN SIN ESCOLARIZACIÓN .................................. 109

2.3. FOUCAULT: PODER, NORMALIZACIÓN, SUJETO...................................... 112

2.4. BOURDIEU: EDUCACIÓN Y REPRODUCCIÓN .......................................... 116

CONCLUSIÓN. LOS DISCURSOS CRÍTICOS DE LA EDUCACIÓN Y EL NUEVO ESPÍRITU DE LA EDUCACIÓN 


\section{PARTE III. \\ PROCESOS Y DINÁMICAS SOCIALES}

\section{CAPÍTULO I. DESARROLLO Y RECONFIGURACIÓN}

DE LA ESFERA EDUCATIVA

INTRODUCCIÓN

1.1. ILUSTRACIÓN Y LIBERALISMO: CIUDADANÍA, SUJETO, PROGRESO

1.2. LA EDUCACIÓN PARA EL PUEBLO: LA CREACIÓN DEL SISTEMA DE EDUCACIÓN DE MASAS.

1.3. LA EROSIÓN DEL PROYECTO EDUCATIVO REPUBLICANO...

1.4. LA RECOMPOSICIÓN DEL PROGRAMA EDUCATIVO MODERNO

1.4.1. Los contenidos y los fines del saber académico

1.4.2. El alumnado como protagonista del aprendizaje

1.4.3. Los nuevos roles docentes

CAPÍTULO II. LAS MUTACIONES DEL UNIVERSO FAMILIAR

INTRODUCCIÓN .

2.1. LA FAMILIA TRADICIONAL: TRANSMISIÓN Y REPRODUCCIÓN SOCIAL

2.2. LA FAMILIA MODERNA: ENTRE EL LAZO INSTITUCIONAL Y EL SENTIMENTAL.

2.3. DE LA FAMILIA REPRODUCTIVA A LA CONVIVENCIAL, DEMOCRÁTICA E INDIVIDUALISTA

2.4. ACTITUDES Y VALORES DE PADRES E HIJOS. ANÁLISIS DE 3 GENERACIONES.

2.4.1. Juventud y familia en los años 60. Entre la reproducción y la aspiración.....

2.4.2. La transición a la familia postmoderna (1975-85). Distancia ideológica y normativa, proximidad afectiva .

2.4.3. De la familia transmisora a la convivencial 
CAPÍTULO III. FORMAS DE VER Y DE CONSTRUIR LA JUVENTUD.

3.1. LA EDUCACIÓN EN LA SOCIEDAD INDUSTRIAL_...................................... 173

3.2. DEL CAPITALISMO DE PRODUCCIÓN AL DE CONSUMO ....................... 175

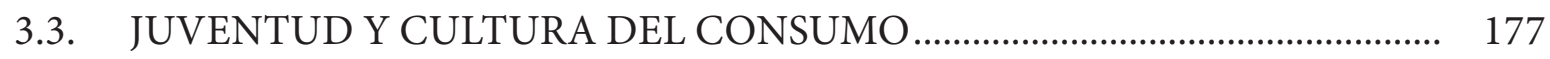

3.4. TRAYECTORIAS GENERACIONALES. ACTITUDES, VALORES Y TEMPORALIDADES DE 3 GENERACIONES DE JÓVENES ESPAÑOLES Y PORTUGUESES EN RELACIÓN CON EL MUNDO DE LA EDUCACIÓN, EL TRABAJO Y EL CONSUMO

3.4.1. Introducción: planteamiento y conceptos

3.4.2. Modos de percibir y de orientar la juventud. Actitudes y valores ante el trabajo, la educación y el consumo de 3 generaciones de jóvenes españoles y portugueses.

\section{CAPÍTULO IV. LA EROSIÓN DE LA AUTORIDAD}

4.1. LA AUTORIDAD Y LA TRADICIÓN EN EL MUNDO PREMODERNO .... 209

4.2. EL DECLIVE DE LA AUTORIDAD Y DE LA TRADICIÓN EN EL PENSAMIENTO EDUCATIVO MODERNO

4.3. LA AUTORIDAD COMO DOMINACIÓN: LA SOCIOLOGÍA CRÍTICA Y LA PEDAGOGÍA LIBERTARIA.

4.4. LOS UNIVERSOS SOCIALES DEL DECLIVE DE LA AUTORIDAD ............ 220

4.4.1. La crisis del sistema de autoridad meritocrático .................................. 221

4.4.2. La ética y la cultura del trabajo postfordistas ....................................... 223

4.4.3. El mundo del consumo. Persuasión y realización personal entre iguales.

4.4.4. De la familia jerárquica a la democrática.

4.5. DE LA AUTORIDAD AL CONTROL. LIDERAR Y ORIENTAR

PARA ENSEÑAR A APRENDER. 


\section{INTRODUCCIÓN}

En pocas ocasiones se ha hablado y escrito tanto de educación, y con un espíritu tan crítico, como en el momento presente. Y pocas veces habían surgido tantas voces reclamando reformas educativas e innovaciones de todo tipo, después de proclamar que todo lo anterior está ya superado y caduco.

En este escenario de proclamas innovadoras y críticas confluyen la mayoría de los sectores que intervienen en el ámbito educativo. Así, proliferan por doquier los informes de distintos organismos que publican rankings y recomiendan reformas. Reformas a las que se apuntan con facilidad los diferentes gobiernos. Los centros educativos anuncian públicamente que su oferta pedagógica es diferente y nueva. Los padres observan con actitud crítica a las instituciones académicas, y con la misma actitud buscan información, procurando elegir aquellas que sean más innovadoras y abiertas. Y los profesores se dividen entre los más veteranos, que toleran mal este espíritu inconformista e innovador, y los más jóvenes, que lo aceptan mejor, o incluso se suman a él con entusiasmo innovador.

En este contexto aparecen, asimismo, nuevos gurús que critican firmemente lo que consideran que son rémoras del pasado, para anunciar con denodado entusiasmo, como si fueran auténticos profetas, la nueva era.

En medio de todo ello el alumnado manifiesta actitudes pasivas o conflictivas, ante instituciones que ya apenas les obligan. Lo cual es fuente de más discusiones, críticas y propuestas de todo tipo.

Tengo la impresión -dijo uno de los más destacados intelectuales de nuestra época- de que nunca hemos dispuesto de tanta tecnología, de que nunca se han escrito tantos libros de pedagogía, de que nunca han proliferado tantas teorías pedagógicas y didácticas, y de que nunca las cosas han estado más confusas (Steiner, 2005: 113-114).

Están confusas porque la perspectiva desde la que se contempla casi todo es la de la propia situación presente, a pesar de que sus categorías, tal como veremos a lo largo de este libro, proceden de un pensamiento mucho más alejado en el tiempo.

En esta obra nos proponemos salir de tal confusión tomando distancia con respecto a la situación que la genera. Para ello, se ha partido de una perspectiva de 
la educación que va mucho más allá de la escuela, entendiendo que las distintas circunstancias por las que atraviesa la institución escolar están relacionadas con aquellos otros ámbitos de socialización y de educación que traspasan el ámbito escolar.

Desde esa perspectiva, la obra se articula a partir de dos grandes vertientes. La primera de ellas se vincula con un punto de vista histórico y genealógico. El análisis histórico tiene por finalidad contemplar la realidad educativa actual desde la tradición occidental premoderna, con el fin de comprenderla, contrastándola con aquellas otras categorías extrañas a ella. El punto de vista genealógico tiene por objetivo reconstruir el proceso de génesis, desarrollo y crítica de una manera de pensar la educación de la que es heredera en buena medida la mentalidad educativa actual.

La segunda vertiente que articula la presente obra está relacionada con los distintos procesos sociales que influyen y configuran la esfera educativa. En este contexto se analizan los cambios experimentados por los sistemas educativos, por la familia y por los jóvenes. Asimismo, se presta también atención al declive de las relaciones de autoridad en los diferentes escenarios sociales, y su sustitución por otros sistemas de control, que tienen un particular reflejo en las actuales instituciones educativas.

De este modo, la obra se estructura en tres partes. La primera se compone de tres capítulos dedicados a describir el mundo de la educación premoderno, partiendo de la antigüedad clásica, a la que estará dedicado el primer capítulo. Continuando con el universo educativo medieval, que se analiza en el segundo capítulo. Y finalizando, en el tercer capítulo, con los modos de educación en la sociedad del Antiguo Régimen.

La segunda parte de la obra tiene por objetivo describir y analizar la génesis, el desarrollo y la crítica del pensamiento educativo moderno, que tanto ha influido en nuestro modo de pensar la educación. Consta de dos capítulos. El primero está consagrado a describir el proceso de conformación y consolidación del pensamiento educativo moderno. El segundo, a analizar aquellos autores que fueron especialmente críticos con este pensamiento, que sin embargo formaba parte también de su propia herencia.

Por último, en la tercera parte se describen y analizan los procesos sociales que han configurado el presente escenario educativo. Nos referimos a los vinculados con los sistemas educativos, al que estará dedicado el primer capítulo. A los relacionados con el mundo de la familia, que se analizarán en el capítulo segundo, tomando como ejemplo el caso español y el portugués. Los que tienen que ver con los cambios en las actitudes y en los valores de la juventud en relación con el mun- 
do de la educación, el trabajo y el consumo, que se mostrarán a través del análisis de tres generaciones diferentes de jóvenes españoles y portugueses. A todo ello estará consagrado el capítulo tercero. Y por último, los procesos relacionados con la erosión de la autoridad en los diferentes ámbitos sociales, y su sustitución por otras formas de control, como las que imperan en el ámbito educativo, que se analizarán en el capítulo final de esta tercera parte.

El libro se cierra con una reflexión, a modo de epílogo, sobre el escenario educativo actual, tomando como base el recorrido realizado a lo largo de las páginas que lo componen ${ }^{1}$.

Algunos de los capítulos que forman parte de esta obra han sido publicados previamente en alguna revista, si bien para su inclusión en dicha obra han sido revisados, introduciendo algunas modificaciones. Es el caso del capítulo 2 de la segunda parte (Durán Vázquez, 2015), y de los capítulos 1 y 3 de la tercera (Durán Vázquez, 2012; Durán y Duque, 2018). 

PARTE I

LA EDUCACIÓN EN EL MUNDO PREMODERNO 



\section{CAPÍTULO I \\ EL MUNDO CLÁSICO: GRECIA Y ROMA}

Es preciso que se busquen para los hijos maestros que sean irreprochables por su género de vida, irreprensibles en sus costumbres y los mejores por su experiencia, pues la fuente y la raíz de una conducta intachable es casualmente una buena educación (Plutarco, 1992 I: 54-55).

\subsection{LOS CONTENIDOS Y LOS FINES DE LA EDUCACIÓN}

La educación antigua tenía como principal meta alcanzar y perfeccionarse en un determinado ideal de vida, ideal que encarnaban los hombres libres, es decir, aquellos que, por disponer de suficientes propiedades, no tenían que trabajar para atender a sus necesidades materiales ${ }^{2}$. Tanto para Platón como para Aristóteles, la libertad estaba asociada a la vida liberada de los esfuerzos necesarios para procurar la subsistencia. "La ciudad mejor- escribe el Estagirita- no hará ciudadano al obrero (...) la virtud propia del ciudadano no se atribuirá a cualquiera, ni al libre solamente, sino a aquellos que estén exentos de los trabajos necesarios" (Aristóteles, 2004: 214). Cicerón consideraba, por su parte, que "todo oficio mecánico era bajo, no siendo posible- decía- que en un taller se halle cosa digna de una generosa educación" (Cicerón, 1959, Libro I, Cap. XLII: 79-80).

La vida buena era, por el contrario, tanto para los antiguos griegos como para los romanos, una vida entregada por completo a ocupaciones no productivas, en las que regía la palabra y la acción, consideradas cualidades supremas de todo ser humano (Arendt, 1998). Así lo enunciaba Fénix, el educador de Aquiles, uno de los arquetipos del héroe griego, cuando recuerda a su discípulo que Peleo le había encargado su educación para que le enseñase "a ser decidor de palabras y autor de hazañas" (Homero, 2006, verso 443, Canto IX: 177).

La educación griega, al igual que la romana, estaba encaminada, pues, a fortalecer a un tiempo el cuerpo y el espíritu, para lograr entre ambos una perfecta armonía (Jaeger, 1996: 24 y 71). Éste era precisamente el ideal platónico:

2 Sobre la valoración del trabajo en el mundo antiguo, con especial referencia a Grecia, pero con validez también para el mundo romano, se puede consultar: Arendt, 1998; Vernant, 1985. 
Si hay alguien en quien coincidan- escribe- una hermosa disposición espiritual y cualidades físicas del mismo tipo que respondan y armonicen con ella, ¿no será éste el más hermoso espectáculo para quien pueda contemplarlo? (Platón, 2003: 201).

Esta moral fue en un principio, en la Grecia de la época arcaica, la de la nobleza guerrera. Más tarde, en la época clásica, se identificará con la Polis, como comunidad de ciudadanos libres que ponían dicha moral al servicio de la ciudad ${ }^{3}$. La Polís se convertirá así en un espacio casi sagrado, al que todos los ciudadanos libres consagrarán sus propias vidas, porque sólo en este ámbito era posible superar las limitaciones que toda vida individual tiene (Arendt, 1998: 220 y ss). Para ser un buen ciudadano, para aspirar al máximo honor y a la gloria, para que, en fin, el recuerdo de los héroes perdurase en la memoria de los vivos, era necesario entregarse a la acción y a la palabra en este espacio así configurado. A cumplir este ideal se consagrará, por tanto, toda la educación griega.

También para los romanos la educación perseguía una finalidad de orden moral que se identificaba con un particular ethos aristocrático, el de los que dedicaban su vida por entero a las armas y a la política, a la palabra y a la acción. No obstante, este estilo de vida estaba representado, no ya por los héroes del pasado o de la mitología, como entre los griegos, sino por los antepasados, cuya memoria era siempre recordada y ensalzada en el seno de la familia (Becchi, 1998a I: 55). Se educa, en palabras de Plinio El joven, para que el hijo "sea algún día la imagen de su abuelo", puesto que "tiene la fortuna de tener por abuelo a un hombre rodeado de veneración y de honor, y también a un padre y a un tío de mucho renombre. A todos ellos se parecerá algún día..." (Citado en Neraudau, 1984: 117).

Ambos pueblos, el griego y el romano, educaban de este modo para dar continuidad a la tradición de la que formaban parte, de la manera más honrosa y honorable posible. "Sólo tiene la medida quien posee la tradición", afirmó el poeta griego Teognis (Jaeger, 1996: 191). Tradición que era la fuente de todos los valores, la que daba sentido a la vida, y a la que, por tanto, era imprescindible vincularse para ser reconocido. "Deviene lo que eres", dirá Píndaro en una de sus elegías (Jaeger, 1996: 207).

Los grandes temas de la educación antigua estaban en relación con este estilo de vida, confiriendo las habilidades y los conocimientos necesarios a quienes quisiesen ser apreciados por sus iguales, por los que tenían en común una misma tradición, unos mismos valores y también unas aspiraciones semejantes (Marrou, 1985: 293). Esta educación, que no perseguía objetivos de orden técnico, sino que

De hecho, lo que Platón pretende en La República es trasladar el ethos de la antigua aristocracia homérica al conjunto de la ciudad (Platón, 2003: 322 y ss). 
estaba orientada a proporcionar un determinado ideal ético, un particular ethos, era la del hombre libre (Marrou, 1985: 67).

Esta era, precisamente, la finalidad que tenían asignadas la gimnasia, la música y la poesía. La poesía porque, según Platón, contiene "muchas historias, y alabanzas, y encomios de las figuras célebres de la antigüedad, que el niño ha de aprender de memoria con el fin de que susciten en él el deseo de imitarlos o emularlos y de llegar a ser como ellos" (Citado en Bowen, I, 1976: 127). La música, en la medida en que "contribuye a la formación del carácter y del alma" (Aristóteles, 2004: 431). "No podremos llegar a ser músicos- escribe Platón-(...) mientras no reconozcamos...las formas esenciales de la templanza, valentía, generosidad, magnanimidad y demás virtudes hermanas de éstas, e igualmente las de las cualidades contrarias..." (Platón, 2003: 201).

La gimnasia, por su parte, ya que quienes la practican lo hacen "con el fin de que su cuerpo sirva mejor al espíritu virtuoso, y para que la flaqueza física no les obligue nunca a mostrarse cobardes en la guerra ni en ninguna otra ocasión" (Platón, 2003: 203 y ss).

Todas estas enseñanzas tenían, como se ve, la misma finalidad moral; estaban destinadas a labrar el carácter, a modelar el comportamiento de los que sin duda llevaban el mismo género de vida, de los que compartían unos mismos valores y unas mismas metas. No era distinto el propósito de aquellas otras enseñanzas que, como la retórica, pudiesen parecer más formales, pero que, sin embargo, tenían la misma pretensión, servir a la vida más elevada de la polis griega o de la res pública romana, proporcionando a los hombres que en ellas se formaban los instrumentos necesarios para persuadir con la palabra, para luchar por alcanzar la mayor preeminencia entre los iguales.

\subsection{LOS MODELOS EDUCATIVOS Y LOS MODOS DE TRANSMISIÓN}

Las ventajas de este estilo de vida, de esta tradición, sólo eran apreciables por quienes con él se identificaban, para los que estaban en condiciones de comprender el sentido que tenía y las ventajas que aportaba luchar por alcanzar determinadas metas en la vida. La educación antigua tuvo así siempre un marcado carácter aristocrático, al estar vinculada con el conjunto de valores que componían esta moral, valores que sólo podían ser adquiridos y apreciados viviendo entre iguales (Jaeger, 1996: 45-47). De ahí la importancia concedida al ejemplo, fuese éste el de los héroes griegos o el de los antepasados romanos; ejemplo que siempre se proponía como modelo de conducta para alcanzar la gloria, la fama y la virtud, y ser así reconocido y ensalzado entre los semejantes. 
Griegos y romanos confiaron de este modo siempre en el valor de la observación y de la imitación, de la adquisición de hábitos que permitiesen apreciar y comprender el valor de lo enseñado. "Se debe educar antes con los hábitos que con el razonamiento”, había señalado Aristóteles (Aristóteles, 2004: 426).

Sólo viviendo, es decir, actuando y hablando en el mismo espacio que habitaban los adultos, podían adquirir los jóvenes el sentido de estos hábitos. Por eso Platón, al referirse en la República a la educación de los guardianes, recomendaba:

Que empiecen desde niños a practicar con modelos dignos de ellos, imitando caracteres valerosos, sensatos, piadosos, magnánimos y otros semejantes (...) ¿No has observado- proseguía- que, cuando se practica durante mucho tiempo y desde la niñez, la imitación se infiltra en el cuerpo, en la voz, en el modo de ser, y transforma el carácter alterando su naturaleza? (Platón, 2003: 187).

El modelo a imitar por el niño era siempre el de los adultos, ejemplo vivo de una tradición que había que asumir para llegar a ser un auténtico ciudadano capaz de intervenir en la vida pública al lado de los iguales. La infancia como tal carecía por ello de importancia, si no era con vistas a la adquisición de este legado cultural representado por el mundo de los adultos ${ }^{4}$ (Neraudeau, 1984: 398-99). En efecto, en tanto el niño no se incorporase al conjunto de normas y de valores que constituían esta tradición, era considerado un ser incompleto, mera potencialidad que debía actualizarse al lado de los adultos para devenir algún día uno de ellos. "Ya que el niño es un ser imperfecto- escribió Aristóteles- es evidente que su virtud no está en relación con un ser actual, sino que está en dependencia de su madurez y de su guía" (Aristóteles, 2004: 148).

Mientras se mantuviese como tal, el niño tenía disminuida incluso su propia humanidad. Su situación era equiparada por ello con la del loco $0^{5}$, pues al igual que éste no era capaz de articular palabras provistas de sentido ${ }^{6}$, al no estar todavía integrado en el mundo común que compartían sus mayores. La capacidad de hablar, de comunicarse con los demás, conllevaba, por tanto, la humanización. "Un ser

$4 \quad$ Buena prueba de que la meta final de la educación era la edad adulta, es que en diversas manifestaciones artísticas, tales como las del arte griego arcaico, los niños aparecen representados como adultos en miniatura (Schnapp, 1996: 4).

5 Tanto Aristóteles en el mundo griego (Aristóteles, 2004: 374), como Isidoro de Sevilla en el romano (Neraudeau, 1998: 77), hicieron uso de este símil entre el niño y el loco. La opinión de que el niño era un ser irracional era corriente en el mundo antiguo (Neraudeau, 1984: 92). En Roma, por ejemplo, la Ley Cornelia consideraba atenuante ser niño o loco, y así preveía que "si un niño o un loco asesinaban a un hombre, no se les arrestara", ya que "uno es protegido por la ausencia de voluntad de causar daño, el otro por la desgracia de su suerte. (Citado en: Neraudeau, 1984: 92-93).

6 Ya el término latino Infans, que literalmente significaba no hablante, evocaba esta singular condición del niño. 
humano habla- escribió Varron- la primera vez que emite una palabra provista de sentido" (Citado en Neraudeau, 1984: 54-55). Pero como el sentido de las palabras sólo comienza a ser pleno cuando se abandona la infancia para entrar en la edad adulta, el niño era considerado todavía un ser irracional, y como tal tenía recortadas sus facultades deliberativas. Desde este punto de vista, su situación era parecida, según Aristóteles, a la del esclavo, a la de la mujer o a la del mismo animal, todos ellos privados de elegir libremente en su vida (Aristóteles, 2004: 147).

En virtud de la situación de debilidad e irracionalidad en la que se encontraba el niño, su educación requería un espacio privado de orden prepolítico, alejado de toda influencia perversa. Así lo entendía Plinio el Joven en una carta dirigida a una amiga, en la que le aconsejaba sobre la educación de su hijo. "Hasta ahoraescribe-, siendo sólo un niño, se le ha mantenido en tu propia casa, y ha tenido preceptores en el hogar, en el que hay muy pocas, o ninguna, por decirlo de algún modo, ocasiones de errar" (Citado en Bonner, 1984: 149). Parecida opinión tenía Aristóteles, que recomendaba que se educase al niño en casa hasta los siete años (Aristóteles, 419: 2004). En un hogar rodeado de adultos, encabezados por el padre, quienes, con su ejemplo y autoridad moral, se encargarían de educarlo (Becchi, 1998a I: 61).

Ante todo- escribió Plutarco- es necesario que los padres, con su conducta intachable y haciendo todo lo que deben, se ofrezcan a sí mismos como ejemplo claro para sus hijos, para que, mirándose en la vida de éstos como en un espejo, se aparten de las obras y palabras vergonzosas (1992: 80).

Todo ello situaba al niño, e incluso al joven, en una posición de subordinación con respecto a los adultos, y en especial a los más ancianos. "La propia naturalezaescribió Aristóteles- ha trazado la frontera al distinguir dentro de las gentes de una misma raza, entre la clase de los jóvenes y la de los ancianos, los unos destinados a obedecer y los otros a mandar" (Citado en Schnapp, 1996: 39).

De este modo, los niños aprendían desde bien pequeños en la propia familia a respetar a los padres, a aceptar su autoridad, como parte de una tradición sacralizada que había que prolongar de la forma más honorable y honrosa posible. Todos los actos sociales en los que participaban desde edad bien temprana, reforzaban el valor y la importancia de este legado cultural (Becchi, 1998a I: 50-51; Schnapp, 1996: 55; Neraudeau, 1984: 149 y ss) 7 .

Ambos, jóvenes y adultos, estaban mezclados en numerosas escenas de la vida privada y de la pública. En el teatro, en actos religiosos y deportivos, en ceremonias familiares, por todos lados se encontraban los niños en compañía de los adultos (Becchi, 1998: 50-51; Schnapp, 1996: 55; Neraudeau, 1984: 149 y ss). 
Desde esta perspectiva, no existía oposición entre la educación familiar y la social. Por el contrario, ambas formaban parte de un mismo orden, que contribuían a reforzar y a perpetuar. Así lo expresaba el escritor latino del siglo II d.C, Aulio Gelio, a través de una discusión en la que se dirimía si había que obedecer siempre al padre: "Algunos responden: sí, siempre. ¿Y si tu padre te ordenara traicionar a la patria? Otros responden con sutileza que en realidad no se le obedece nunca, puesto que a quien se obedece es a la moral, cuyas órdenes el padre expresa" (Citado en Veyne, 1989: 42).

Desde el momento en que el niño comenzaba a asumir aquella tradición proveniente de sus mayores, se convertía en un ser juicioso, reflexivo, provisto de razón. Su educación proseguía entonces fuera de la familia, en presencia de personas adultas de la confianza del padre; personas que, mediante su consejo y ejemplo, continuaban la formación del joven en los dos campos en los que discurría la vida de todo hombre libre, el militar y el político.

\subsection{LA CONDICIÓN DE LA ENSEÑANZA ESCOLAR}

Frente a este tipo de aprendizaje de orden moral, que descansaban en la imitación y en el ejemplo, la enseñanza escolar era totalmente secundaria (Marrou, 1985: 196 y 303), ya que se consideraba que apenas contribuía a la conformación del estilo de vida del hombre libre. Por eso, tanto griegos como romanos desdeñaron este tipo de enseñanza, en favor de la que tenía lugar dentro del hogar ${ }^{8}$, bajo la vigilancia de la familia (Plutarco, 1992: 68).

Así, los conocimientos técnicos e instrumentales, que tenían una finalidad fundamentalmente utilitaria', tales como saber leer, escribir y contar, gozaban de escaso prestigio entre griegos y romanos, al estar fuera del campo de los intereses vitales del hombre de condición elevada. Si hemos de hacer caso a la opinión de Quintiliano, los romanos pertenecientes a los estratos sociales superiores apenas otorgaban importancia a saber escribir bien (Bowen, 1976 I: 272). Para ellos, sólo

8 Griegos y romanos concedieron un papel preponderante a la educación privada frente a la pública. De hecho, el Estado nunca se preocupó por financiar directamente la enseñanza pública, que casi siempre estuvo apoyada por particulares (Becchi, 1998: 53 y 56; Neraudeau, 1998: 313; Marrou, 1985: 345).

$9 \quad$ Esta clase de conocimientos eran más propios de los asalariados, de aquellos que, por estar sometidos al imperio de la necesidad, se veían obligados a tener que trabajar para vivir. Los griegos y los romanos nunca tuvieron en alta consideración los saberes pertenecientes al campo de las techné. En efecto, el técnico simplemente domina un conjunto de habilidades con un fin utilitario relacionado con la vida material, fin que está completamente alejado de las que se consideran formas superiores de vida, a saber, del pensamiento reflexivo, de la contemplación, de la acción en medio de los iguales, para lo cual lo que cuenta es ante todo la palabra (Vernant, 1985: 280 y ss). 
era importante la sabiduría basada en la tradición, vinculada a un particular estilo de vida, que sólo era posible adquirir viviendo entre gentes de condición semejante. Para apropiarse de este saber, era necesario contar con disposiciones de orden moral que ningún conocimiento técnico podía otorgar ${ }^{10}$. Por este motivo, griegos y romanos jamás concedieron prestigio alguno al oficio de maestro ${ }^{11}$. De él se valoraban sobre todo los aspectos de orden moral, sin que se mencionase apenas su vertiente técnica (Marrou, 1985: 196). Aunque otros oficios relacionados con la educación gozaban sin embargo de más alta estima, como los de los profesores de retórica, ello se debía a que sus enseñanzas no eran ya de orden técnico, sino a que estaban orientadas a dominar el arte de la palabra, imprescindible para todos aquellos que, por su género de vida, tenían que tratar con sus iguales para persuadirlos y convencerlos (Vernant, 1985: 301). Esta era la meta de la educación, hacer personas virtuosas, capaces de usar la palabra entre hombres nobles y libres. Por eso el emperador romano Vespasiano tenía en alta estima a gramáticos y a retóricos, porque "educan a la juventud para la nobleza y la virtud cívica" (citado en Bowen, 1976 I: 273-274). Para lo cual, como se dijo, era más importante la sabiduría moral que el conocimiento técnico. De ahí que el escritor griego Plutarco aconsejase que se "busquen para los hijos maestros que sean irreprochables por su género de vida, irreprensibles en sus costumbres y los mejores por su experiencia" (Plutarco, 1992: 54-55).

El éxito de la educación antigua, griega y romana, quizás haya residido en la seguridad que demostró en la transmisión de este ideal de vida (Neraudeau, 1984: 334). Una seguridad que nacía de la confianza en un mundo común, en una misma tradición, que otorgaba a los adultos la autoridad necesaria para integrar en ella a niños y a jóvenes.

Esta confianza no desapareció en el mundo medieval. Y con ella se mantuvo también la firme voluntad de proporcionar a los más jóvenes un saber que les permitiese entrar en un mundo que más tarde sería el suyo. La forma en que esto ocurrió será el tema del próximo capítulo.

10 Desde el punto de vista moral era más importante el papel del pedagogo, que, a pesar de su baja condición, por estar integrado en la casa podía acompañar al niño en numerosas ocasiones y corregirle así su comportamiento (Marrou, 1985: 196 y 289: 346-347).

11 El maestro integraba el mundo de las ocupaciones asalariadas desempeñadas por hombres que no eran libres, porque tenían que someter su voluntad a la de otro (Aristóteles, 2004: 423-24). Ver también (Marrou, 1985: 347; Bowen, 1976 I: 256-57 y 272; Bonner, 1984: 195 y 197 y ss). 



\section{CAPÍTULO II LA EDUCACIÓN EN EL MEDIEVO}

En la Edad Media era la sociedad como un todo la encargada de modelar a los individuos (...) Lo más significativo es que la regulación y la represión a la que se sometía la vida impulsiva de los adultos eran notablemente menos estrictas que en la fase siguiente de la civilización y, a consecuencia de ello, también era menor la diferencia entre el comportamiento de los adultos y el de los niños (Elias, 1993: 182).

\subsection{ENTRE LA TRADICIÓN CLÁSICA Y LA CRISTIANA}

El mundo medieval dio continuidad en muchos aspectos a las concepciones educativas clásicas, aunque en algunos otros inauguró una nueva forma de entender la educación propiamente cristiana.

En efecto, desde el momento en que el cristianismo atribuía a la vida un carácter sagrado, el recién nacido llegaba al mundo con la condición de persona humana (Riché.; Alexander-Bidón, 1994: 44). Desde este punto de vista, la diferencia era radical con respecto a la civilización greco-romana, que ignoraba por completo al neonato, mientras éste no fuese aceptado por la familia, y se ingresase así en el mundo.

Diferente era también la condición del padre para la mentalidad cristiana, puesto que carecía del poder casi absoluto que le había atribuido la civilización romana antigua. En efecto, el hecho de que el cristianismo situase la figura de DiosPadre por encima de la del padre, contribuyó a limitar el poder de éste sobre la prole. Como se puede leer en el Evangelio según San Mateo: "Quien ama a su padre o a su madre más que a Mí, no es digno de Mí; y quien ama a su hijo o a su hija más que a Mí, no es digno de Mî” (Mt 10,37).

Por lo demás, como luego se verá, las concepciones educativas medievales no se apartaron demasiado de las greco-romanas.

$\mathrm{Al}$ igual que estas últimas civilizaciones, la sociedad medieval confirió a la educación un fin de carácter moral antes que técnico. Esta moralidad, profunda- 
mente cristiana, daba sentido a todas las vertientes de la vida, y por tanto también a la tarea de educar. Era frecuente que en los libros para niños se propusiese como ejemplo moral la infancia de Cristo, y que las hijas de la nobleza leyesen libros de piedad (Riché; Alexander-Bidon, 1994: 111 y 143). Esta misma finalidad moral estaba también presente cuando se trataba de educar al futuro campesino, al artesano o al que sería más tarde caballero. Y también cuando las madres se proponían educar a sus hijas.

Las concepciones educativas medievales integraron de este modo la mentalidad greco-romana y la cristiana para componer una determinada visión de la educación, de la infancia y de la juventud.

\subsection{LAS CONCEPCIONES DE LA INFANCIA Y DE LA JUVENTUD}

Debido a que todavía estaba más fuera que dentro del mundo, sobre todo antes de ser bautizado, el niño era percibido en sus primeros años de vida por la mentalidad medieval de una forma ambigua, a medio camino entre el bien y el mal, por lo que podía adquirir fácilmente tanto las malas como las buenas costumbres (Alexander-Bidon.; Lett, 1997: 73; Lett, 1997: 66). Este carácter extramundano, que se atribuía a quien llevaba aún poco tiempo entre los hombres, estaba ya presente en el mundo clásico antiguo. Así, Plutarco comentaba, a propósito del entierro de su hija de dos años, que la ceremonia había sido breve, pues la difunta aún no formaba parte del mundo, por lo que era mucho más fácil su regreso al cielo (Lett, 1997: 66).

Debido a esta condición liminal, el niño carecía en sus primeros años de vida de las capacidades que lo habrían de convertir más tarde en un hombre completo (Lett, 1997: 59). Su figura estaba por ello muy poco presente en los relatos de milagros, y también en la mayoría de los textos literarios medievales, en los que aparecía el recién nacido, el puer o el adolescente, pero casi nunca el infans. Asimismo, tanto médicos como pedagogos restaban importancia a esta etapa de la vida, marcada por la debilidad y la irracionalidad ${ }^{12}$ (Lett, 1997: 29 y 31 ).

12 Para los primeros, la extrema humedad y calor que tiene el niño en esta etapa de su vida explicaría su carácter frágil, débil e intemperado. En opinión de Gilles de Roma "los niños carecen frecuentemente de entendimiento, porque su alma sigue habitualmente la complexión del cuerpo, y cuando el cuerpo está mal o débilmente constituido, no puede conocer ni entender perfectamente la verdad". Frente a él, las personas viejas, por su falta de calor, serían excesivamente moderadas, mientras que las maduras, aquellas que han alcanzado la "edad perfecta", tendrían la dosis adecuada de calor y también de equilibrio (Lett, 1997: 96-97 y 98). En suma, el niño, por su exceso de calor, sería extremadamente inquieto e irracional. 
En razón de esta condición fronteriza entre lo mundano y lo extramundano, convivieron en la Edad Media dos concepciones antagónicas acerca de la primera infancia- etapa de la vida que se extendía aproximadamente hasta los 3 años- herederas del mundo clásico (Becchi, 1998b: 110-111).

Por un lado, la llamada infantia ${ }^{13}$, era considerada una edad peligrosa llena de debilidades e incertidumbres, ya que en ese periodo el niño estaba aún, tal como se ha dicho, más fuera que dentro del mundo. Por el otro, precisamente por este hecho, y siguiendo la tradición romana y también la del Nuevo Testamento, la infancia era concebida como pura, inocente y sagrada, al no estar todavía contaminada por los males del mundo (Becchi, 1998b I: 109 y ss; Alexander-Bidon.; Lett, 1997: 41; Riché, 1995: 367). Así se puede leer en el Evangelio según San Marcos:

Le trajeron unos niños para que los tocase, más los discípulos ponían trabas. Jesús viendo esto, se molestó y les dijo: “Dejad a los niños venir a Mí y no les impidáis, porque de tales como éstos es el reino de Dios. En verdad, os digo, quien no recibe el reino de Dios como un niño, no entrará en él" (Mar$\cos , 10,15)$.

Esta imagen de inocencia y de pureza será difundida a lo largo de la Edad Media, sobre todo por los escritos monásticos, y en especial por los de la Regla de San Benito (Becchi, 1998b I: 111). Por este motivo, algunos santuarios estaban consagrados a los niños, y ante ellos rogaban los fieles para hacer diversas peticiones (Riché.; Alexander-Bidón, 1994: 23 y 198-199). Se consideraba, asimismo, que los niños eran irresponsables de sus actos ante Dios, siendo objeto de una especial protección, por ser una especie de mediadores entre Dios y los hombres (Lett, 1997: 64-65). Así, los que tenían menos de cinco años eran protagonistas de numerosos actos religiosos en los que actuaban como intermediarios entre Dios y los hombres, pues como seres inocentes que eran se creía que siempre decían la verdad (Riché.; Alexander-Bidón, 1994: 23 y ss) ${ }^{14}$.

Junto a esta imagen positiva de la primera infancia, existía otra negativa, que continuaba la tradición greco-latina, y también la del Antiguo Testamento, y que respondía a varias razones.

En primer lugar, se entendía que el niño, en este primer periodo de su vida, nacía tocado con la impureza del pecado original, y como tal era un ser propenso a la maldad (Becchi, 1998b I: 111-112). Su imposibilidad para hablar, para articular

13 Antes de que el niño cumpliese los dos años existía otro término para denominarlo, infantulus, si es niño, o puella, si se trata de una niña; en ambos casos el sufijo ulus alude a lo afectivo del concepto (Lett, 1997: 44).

14 Así, era frecuente que los niños acompañasen al féretro en los cortejos fúnebres para espantar el diablo (Lett, 1997: 66). 
un discurso coherente, eran signos de aquel pecado original con el que todo ser humano nacía; pecado que, sin embargo, tendría que ser purgado entre los hombres (Lett, 1997: 90). "Quien me va a recordar el pecado de mi niñez- escribe en las Confesiones San Agustín- ya que nadie está puro ante Dios, ni incluso el niño que no ha vivido más que un día sobre la tierra..." (Citado en: Riché.; Alexander-Bidón, 1994: 22). Crecer era, pues, en este caso ir apartándose del diablo y de sus tentaciones (Pastor, 1986: 93).

La primera infancia era considerada también una edad inclinada a la desmesura, y por ello alejada de la virtud, que residía en la temperancia. Este pensamiento, de raíz aristotélica, que equiparaba la primera infancia con el exceso descontrolado, será prolongado más tarde por Tomás de Aquino, y se asentará al final de la Edad Media, en los siglos XII y XIII (Lett, 1997: 97). La ausencia de capacidad de razonamiento y de comprensión en la primera infancia será por tanto un tema recurrente en los autores medievales, profundamente influidos por el pensamiento Agustiniano, que en realidad era una continuación del aristotélico, que más tarde prolongará, como se ha visto, Tomás de Aquino (Riché.; Alexander-Bidón, 1994: 22). Uno de estos autores, cuya opinión tendrá también gran influencia durante toda la Edad Media (Goodich, 1998: 152), fue Isidoro de Sevilla, para quien el infans era el que todavía no sabía expresarse (Lett, 1997: 28).

Esta falta de razonamiento y de reflexión, que conducía a la infancia a una actitud inmoderada y excesiva, explica que el niño fuese equiparado en esta primera etapa de su vida, siguiendo el pensamiento clásico, al loco. En efecto, al igual que éste, no diferenciaba el bien del mal; como él tampoco pronunciaba palabras razonables, con sentido común. Por este motivo, su lenguaje era considerado peligroso, al ser incontrolado, desordenado, espontáneo e irreflexivo. De ahí, que la mayoría de los tratados pedagógicos medievales se preocupasen de cómo enseñar a los niños a hablar bien; no tanto a vocalizar correctamente las palabras, sino a enunciar un discurso de forma ordenada y con sentido. Por ello se aconsejaba que los juegos fuesen reflexivos y moderados (Becchi, 1998b I: 116; Lett, 1997: 96-97 y 103 y ss).

Esta concepción de la infancia difundida por el Tomismo, que continuaba, tal como se ha visto, la tradición clásica, aparecerá también reflejada en la cultura popular. En efecto, numerosos proverbios medievales aludían a la incapacidad que tenía el niño para distinguir el bien del mal: "Debemos protegernos del loco y del niño", decía uno de ellos; "avergüénzate de las maneras del loco y del niño", se decía en otro. Estas mismas ideas se repetían en los documentos médicos, teológicos y jurídicos (Lett, 1997: 101). Algunas fiestas medievales reflejaban, asimismo, esta condición de la infancia. Era el caso de la de los Santos Inocentes, conocida también como la fiesta de los locos, en la que los niños tenían un especial protagonis- 
mo, sobre todo desde el siglo XI. En ella jugaban, como si de un carnaval se tratase, a invertir los papeles sociales, liberando así sus pulsiones (Becchi, 1998b I: 123; Riché.; Alexander-Bidón, 1994: 198).

A partir de los 3, y hasta los 7 años, se consideraba que el niño entraba en una segunda etapa de su vida, en la que perdía su condición de ser inocente y sagrado, sin haber adquirido todavía la capacidad para refrenar sus impulsos. Seguía sin despertar, por ello, demasiado interés en médicos, pedagogos y clérigos, sino era para advertir de su peligrosidad potencial, e insistir en que debía ser corregido y reconducido (Lett, 1997: 91 y 299).

No obstante, al entender que su naturaleza era flexible y maleable, y que por tanto podía imprimirse en ella todo lo que se desease (Lett, 1997: 56 y ss), se creía que podía ser educado en la mejor dirección posible, siguiendo el ejemplo de los adultos.

Este proceso comenzaba alrededor de los 7 años, cuando el puerulus de la etapa anterior devenía ya puer. Era el momento en el que el niño era capaz ya de razonar, diferenciando entre el bien y el mal, pudiendo expresarse y ser comprendido (Becchi, 1998b I: 113). Era entonces cuando podía confesarse, y, por tanto, reflexionar sobre sus pecados y arrepentirse de ellos (Pastor, 1986: 93). A partir de entonces, se convertía en un sujeto moral (Lett, 1997: 29).

La infancia entraba así en la denominada "edad de la razón”, empezando a ser objeto de atención por parte de pedagogos y de eclesiásticos, preocupados por su educación humana y cristiana (Becchi, 1998b I: 114; Lett, 1997: 299-300). Una educación destinada a borrar las imperfecciones infantiles, para introducir en su lugar todas las características propias del ser humano adulto.

Con este propósito había primero que reprimir y eliminar todos aquellos aspectos que hacían de la infancia una edad tendente al exceso y a la irracionalidad. Para después introducir en ella la inclinación contraria, la moderación ${ }^{15}$. Este temperamento más pausado, temperado y reflexivo sólo podía ser adquirido cuando el niño era capaz de razonar, es decir, cuando podía comprender el significado de las enseñanzas que le proponían los adultos, impregnadas de un fuerte contenido religioso y moral. Era entonces cuando comenzaba el aprendizaje de sus primeras plegarias, y podía ser ya confirmado (Lett, 1997: 108 y ss).

A los 12 años, aproximadamente, terminaba la infancia y comenzaba la adolescencia, edad a la que se consideraba aceptable el matrimonio en el caso de las

15 La moderación será uno de los principales temas de reflexión para muchos autores medievales, que verán en ella una dimensión fundamental de la virtud, de la que carecía, por el contrario, la infancia. Tomás de Aquino titulaba de este modo un artículo de su Summa Teológica “Es la intemperancia un pecado pueril?” (Citado en: Lett, 1997: 97). 
mujeres; una edad que en el caso de los hombres se prolongaba hasta los 14 años. Esta etapa estaba rodeada aún de numerosas ambigüedades e incertidumbres. En efecto, aunque se había adquirido ya el sentido común, la capacidad para dialogar con quienes estaban ya en pleno uso de la razón, integrándose por tanto con ellos en el mundo, todavía era en una edad llena de incertidumbres, en la que el cuerpo y la mente estaban convulsos. El monje benedictino del siglo XII, Julien de Vézelay, lo expresaba del siguiente modo:

A la infancia- escribía- le sucede la adolescencia, edad sensual e indisciplinada, ávida de placer, que cree que la virtud es pesada y difícil (...) No podemos comprender la trayectoria del hombre en el curso de su adolescencia, porque es realmente inestable, no se deja guiar ni por la razón ni por los consejos de otro; sometida a tentaciones varias, móvil y vagabunda, se deja arrastrar por esto y por aquello. Un día quiere, al día siguiente ya no quiere. Hoy ama, mañana odia (Citado en Riché.; Alexander-Bidón, 1994: 202).

La adolescencia se extendía hasta bien entrada la veintena. Y así se seguirá considerando hasta mucho más tarde, tal como lo ponen de manifiesto a comienzos del siglo XVI los Coloquios de Erasmo (Erasmo, 2005: 47). Finalizada la adolescencia comenzaba la juventud, que duraba, más o menos, hasta los 35 años (Pastoureau, 1996: 282). Tanto la adolescencia como la juventud eran percibidas por los moralistas medievales como la edad de las pulsiones, inestable y extremadamente cambiante (Crouzet-Pavan, 1996: 217 y 235; Pastoureau, 1996: 291). Se creía que tanto los adolescentes como los jóvenes rehuían el esfuerzo y se entregaban con frecuencia a los placeres, por lo que estaban sometidos permanentemente a diversas tentaciones y transgresiones, sin respetar las razones ni los consejos ajenos. De ahí, que se considerasen también edades poco juiciosas y razonables, y asimismo especialmente peligrosas y sacrílegas (Alexander-Bidon., Lett, 1997: 45; Lett, 1997: 120 y ss; Pastoreau, 1996: 296-297). Y de hecho, en la sociedad medieval, como en otras, los jóvenes se comportaban de forma transgresora, despertando aún más los temores de los adultos, que expresaban una y otra vez la voluntad de reconducirlos (Pastoreau, 1996: 297).

\subsection{LA EDAD ADULTA COMO MODELO Y COMO META}

Para refrenar todos los excesos y las irracionalidades propias de la infancia, de la adolescencia y de la juventud, ofreciendo las enseñanzas más adecuadas a la futura condición de la persona adulta, la mentalidad medieval confiaba en las instituciones, y en las palabras y los ejemplos proporcionados por los adultos. Y confiaba también en las posibilidades que ofrecía la naturaleza infantil para ser 
moldeada en la dirección que aquellos considerasen ${ }^{16}$. Sin condicionamientos previos, pues se entendía que el alma infantil era como una tabula rasa en la que el educador podía gravar todo lo que se propusiese (Lett, 1997: 62).

Para ello, como antes se ha dicho, había que introducir gradualmente al niño en el mundo de la mano de los adultos. La civilización medieval consideraba, como antes lo había hecho la greco-romana, que el hombre era la medida del mundo. Y que esta medida estaba representada por el ser humano adulto; la llamada "edad perfecta" (Pastor, 1986: 88), que se situaba para la mayoría de los autores medievales alrededor de los treinta años, momento en el que Cristo comenzó a realizar sus primeros milagros. Con respecto a esa edad, las demás edades no eran sino etapas transitorias, llenas de peligros e imperfecciones, que había por tanto que superar lo más rápidamente posible (Becchi, 1998b I: 115; Lett, 1997: 29-30; 93 y ss). Así lo entendía el religioso Gillaume Durand, haciéndose eco de la mentalidad de la época (Riché.; Alexander-Bidón, 1994: 22 y 194). Y así se mostraba también en las imágenes de la juventud, la antesala de la edad adulta.

En dichas imágenes los jóvenes aparecían representados en relación al grupo en el que se encuadraban, mostrando así que carecían de una particular identidad, sino era con respecto a la secuencia de las demás edades. Para señalar este hecho visualmente, las distintas edades aparecían dispuestas en una gradación de estatura acorde con su importancia social. Siendo así que el niño era el más bajo, a continuación aparecía el joven, después venía el hombre maduro, y por último el viejo, el de estatura más elevada. No obstante, a esta pirámide de edades se superponía, cuando era el caso, la correspondiente a la de los diferentes órdenes sociales, de tal manera que las gentes pertenecientes a un estamento superior tenían mayor estatura que las de otro inferior, con independencia de la edad que tuviesen (Pastoureau, 1996: 290) ${ }^{17}$.

El estatus que confería la edad se indicaba, asimismo, habitualmente por el lugar que ocupaba cada persona en el espacio de la escena representada. En este contexto, los niños y los jóvenes aparecían en los extremos del cuadro, mientras

16 Desde esta perspectiva, se entendía que el cuerpo del bebé era como un trozo de cera al que se podía dar la forma más adecuada. "Al igual que la cera que cuando es blanda adquiere la forma que uno quiere darle- escribe el médico del siglo XIII Aldebrandin de Siena-, el niño adquiere la forma que la nodriza le da" (citado en Lett, 1997: 56).

$17 \quad$ No obstante, a veces se resaltaba la edad más que la condición social, cuando se trataba de destacar, por alguna razón, este hecho en la figura representada. De este modo, dicha figura aparece con una menor estatura, aun siendo su condición social o simbólica superior a la de las personas que comparten su mismo espacio. Era el caso de la iconografía de Jesús niño, tal como se muestra en el evangelio de San Lucas, en el que éste se dirige a los doctores con tan sólo 12 años, mostrando una sabiduría impropia de una persona de su edad. Para destacar el acontecimiento la poca estatura de Jesús contrasta con su elocuencia (Pastoureau, 1996: 290). 
que las personas de más edad ocupaban el centro. Circunstancia que también se señalaba cuando las figuras se ofrecían en distintos planos, de menor a mayor estatura (en una pintura como la medieval que desconocía la perspectiva), ocupando el plano menos profundo los más jóvenes, y el de más profundidad los que más edad tenían (Pastoureau, 1996: 288 y ss).

Todas estas imágenes reflejaban una vez más que la meta de la vida era siempre alcanzar la edad madura, con respecto a la cual todas las demás edades eran imperfectas, y por tanto etapas de transición que había que superar para llegar a dicha meta. Por eso, los tratados pedagógicos medievales tenían como destinatarios a los adultos, y no a la infancia o a la juventud, pues eran ellos los responsables de educar a sus descendientes para introducirlos progresivamente en su propio mundo (Becchi, 1998b I: 116-117). Entre los adultos se educaban así jóvenes y niños por medio de la observación y el ejemplo que aquellos les ofrecían.

\subsection{LAS PERSONAS, LOS MODOS Y LOS CONTENIDOS DE LA EDUCACIÓN}

Esta educación comenzaba primeramente en la familia, en la que el padre detentaba la autoridad ${ }^{18}$ (Riché.; Alexander-Bidón, 1994: 90). En el medio familiar se transmitía la moral, la cultura y también los conocimientos necesarios para la vida material. En este proceso desempeñaba un papel destacado la madre, sobre todo en los primeros años de vida de los hijos. Hasta aproximadamente los 7 años ella era la encargada de transmitirles afecto, de iniciarles en la fe cristiana y de enseñarles a leer y a contar (Becchi, 1998b I: 117-118). Esta función era más importante, si cabe, en el caso de las hijas, a las que la madre iniciaba en todo lo relativo a la vida afectiva y doméstica (Alexander-Bidon., Lett, 1997: 79-110 y ss; Riché.; Lett, 1997: 155; Alexander-Bidón, 1994: 94 y 99).

El padre intervenía más tarde, entre los ocho y los doce años (Becchi, 1998b I: 117-118), implicándose directamente en la educación de sus hijos varones, valiéndose de la palabra y del ejemplo como medios de enseñanza. Para ello, los niños acompañan en todo momento a sus progenitores, tanto en sus tareas cotidianas como en sus esparcimientos (Alexander-Bidon., Lett, 1997: 115; Riché.; Alexander-Bidón, 1994: 100).

Todos los moralistas medievales aconsejaban a los padres cómo educar a su prole, haciendo especial hincapié en la enseñanza moral y en la disciplina. Tal como se puede leer en un escrito de un predicador francés del siglo XIII:

\footnotetext{
18 Aun así, como se ha dicho, la autoridad del padre no era tan absoluta como en la familia romana, y estaba normalmente atemperada por la comunidad (Riché.; Alexander-Bidón, 1994: 92).
} 
Si primero se enseña la virtud y la disciplina- decía-, los niños siempre conservarán algo de ella, si se les enseña la glotonería, la bribonería, serán golfos y crápulas. Las pobres gentes no tienen preceptores como los grandes de este mundo, tienen que educar ellos solos a sus niños, deberán responder de sus niños el día del juicio final, como un prior, un abad y todo superior de convento deberá responder de su comunidad (Citado en Riché.; AlexanderBidón, 1994: 97).

A partir de los 12 años, disminuía progresivamente la presencia del padre en la educación de sus hijos en favor de otras personas. Momento en el que éstos comenzaban a ganar autonomía. Una autonomía que se reforzaba al final de la infancia, cuando aumentaban las tensiones con el padre. La madre seguía, sin embargo, manteniendo hasta más tarde una relación más estrecha con sus hijas (Lett, 1997: 172 y ss).

Ahora bien, más allá de estas pautas comunes, los medios y las formas de enseñanza variaban en función de los diferentes grupos sociales.

En la nobleza, por ejemplo, el padre educaba a sus hijos desde bien temprano, alrededor de los 4 años, en el oficio de las armas, mediante la enseñanza de la equitación, la caza y el manejo de las armas (Alexander-Bidon., Lett, 1997: 79-80.; Riché-Alexander-Bidón, 1994: 160-161). Este aprendizaje, en el que se mezclaban las artes de la guerra y del deporte, las letras y las buenas maneras, proseguía más tarde, a partir de los 7 años, cuando los jóvenes nobles entraban al servicio de otro caballero, normalmente un preceptor ${ }^{19}$, familiar o amigo del padre (Bowen, 1985 II: 56; Pastor, 1986: 91; Becchi, 1998b I: 118-119; Alexander-Bidon., Lett, 1997: 194.; Riché-Alexander-Bidón, 1994: 116 y ss). Este preceptor, llamado Ayo, debe continuar la educación del padre, tal como se muestra en las Partidas de Alfonso X “El Sabio":

...después que lleguen a mozos- se dice- conviene que les den ayos que los guarden y que los refinen en su comer y en su beber y en su hablar y en su continente, de manera que lo hagan bien y apuestamente según les conviene. Ayo quiere decir en lenguaje de España, hombre a quien se le da a (nodrir) educar mozo, ha de tener gran entendimiento para mostrarles cómo se hace bien... porque dijeron los sabios que son los mozos quienes aprenden las cosas mientras son pequeños como la cera blanda cuando le ponen el sello... Y por ende los ayos deben educar a los mozos mientras que son pequeños que aprenden entonces las cosas que convienen... Mas si se las quisieren mostrar cuando fueren mayores, y comenzasen ya a entrar en la mancebía no se podrá hacer tan ligero... (Citado en Pastor, 1986: 91-92).

19 En ausencia de un preceptor, la nobleza confiaba sus hijos a algún monasterio para que fuesen educados durante un periodo de tiempo previamente acordado (Riché-Alexander-Bidón, 1994: 118 y ss). 
Con esta finalidad educativa, los clérigos de la época carolingia escribirán tratados de buenas costumbres destinados a los miembros más jóvenes de la alta nobleza. La ciencia y la caballería, tal como se dice en los que comienzan a proliferar en los siglos XII y XIII, se convertirán en fundamentales para la formación del joven noble (Alexander-Bidon., Lett, 1997: 217; Riché-Alexander Bidón, 1994: 159). Aunque de la ciencia basten aquellos conocimientos necesarios para la formación social y moral del caballero. Así lo expresaba el teólogo y filósofo italiano Gilles de Rome (1247-1316), a propósito de la educación de los futuros príncipes:

De algunas ciencias -escribía- deben saber lo que puede servir a su desarrollo moral; de la gramática, lo suficiente para conocer el idioma en el cuál son enseñadas las verdades de la moral y de la religión; de la retórica y de la dialéctica... la forma de expresarse más fácilmente y con más contundencia; de la música, lo que pueda conducirles a las buenas costumbres. De las demás ciencias, basta con que tengan una noción ligera (citado en Alexander-Bidon., Lett, 1997: 218).

En cuanto a las enseñanzas caballerescas, que incluían la formación en las artes de la guerra y del deporte, seguirán recomendándose por los pedagogos, incluso al final de la Edad Media, cuando la cultura cortesana sustituya progresivamente a la guerrera (Alexander-Bidon., Lett, 1997: 197-198).

Alrededor de los 16 o 17 años los hijos de la nobleza así educados se convertían en escuderos. Al final de la Edad Media, muy pocos de estos jóvenes llegarán a ser caballeros. Es el momento en el que el mundo de la corte, con sus formas y sus comportamientos, sustituirá poco a poco al de la guerra (Alexander-Bidon., Lett, 1997: 195-196; Pastor, 1986: 96-97).

Por lo que se refiere a las hijas de la nobleza, normalmente eran confiadas a preceptoras, que siempre las acompañaban, transmitiéndoles los usos y las costumbres apropiadas a su género y estamento. Estas virtudes requerían también el aprendizaje de la equitación y de la caza, que se completaba con una educación intelectual que sobrepasaba la que recibían sus hermanos varones. No obstante, tenían peor consideración que éstos, puesto que no prolongaban el linaje, y además había que dotarlas para buscar alianzas con otras familias nobles (AlexanderBidon., Lett, 1997: 83 y 210).

La educación de los hijos e hijas de los demás estratos sociales de condición no nobiliar obedecía también a fines morales y sociales. Tenía lugar, asimismo, bajo la atenta mirada de los adultos, quienes la dirigían con la palabra y el ejemplo (Goodich, 1998: 151). Tenía que responder, sin embargo, a otros cometidos, más acordes con el grupo social al que estaba destinada.

En el campo, por ejemplo, la infancia trabajaba desde muy temprano en las faenas domésticas (Alexander-Bidon., Lett, 1997: 126; Le Roy Ladurie, 1975: 318). 
En ocasiones, por iniciativa del cura parroquial, podían acudir a la escuela en invierno a aprender una instrucción elemental, cuando las faenas agrícolas no los reclamaban (Riché.; Alexander-Bidón, 1994: 166-67).

En el mundo urbano el aprendizaje de un oficio comenzaba también muy pronto, desde que el niño comenzaba a hablar con sentido, alrededor de los 5 años, y bajo la tutela del padre. Esto es lo que aconsejaban precisamente muchos moralistas, como Ramón LLul o Philippe de Novare (Alexander-Bidon., Lett, 1997: 126135.; Riché.; Alexander-Bidón, 1994: 162).

Estas enseñanzas, que tenían lugar normalmente en el propio lugar de trabajo, iban acompañadas de distintos consejos. En todo caso, se trataba de un aprendizaje que iba mucho más allá de la adquisición de unas determinadas destrezas técnicas, ya que comportaba ante todo la integración en un determinado universo sociomoral, presidido por el respeto que la infancia y la juventud debía profesar a sus padres, preceptores y pedagogos (Alexander-Bidon., Lett, 1997: 134-135 y 216).

A partir de los 12 años era común que el niño abandonase su casa para ir a aprender, durante unos 2 años, un oficio al taller de un maestro. En el caso de las niñas era frecuente que entrasen al servicio de una señora para realizar distintas tareas domésticas (Alexander-Bidon., Lett, 1997: 152 y ss).

Al margen de todas estas enseñanzas que tenían lugar en el ámbito familiar, doméstico y profesional, la infancia se socializaba desde bien temprano en la calle o en el campo, participando de los acontecimientos de la vida adulta (Becchi, 1998b I: 126). Así, era frecuente ver a niñas y a niños en entierros y otros actos de carácter religioso, manifestando la inexistencia de una clara separación entre el mundo infantil y el adulto (Alexander-Bidon., Lett, 1997: 173 y ss). Separación que tampoco se daba, tal como se ha visto, en otras esferas de la vida. En efecto, tanto en el medio familiar y doméstico, como en el profesional, así como en la vida pública, la juventud y la infancia aparecían constantemente mezcladas con los adultos, participando y observando un mundo, que más tarde sería el suyo (Becchi, 1998b I: 119; Ariès, 1987: 10).

En comparación con los procesos de socialización y de enseñanza hasta aquí descritos, la formación escolar apenas tuvo importancia en la Edad Media, como a continuación se verá.

\subsection{LA DEBILIDAD DE LA ENSEÑANZA ESCOLAR}

En la edad Media sólo una minoría de la población se educaba en las escuelas $y$ en los monasterios, en un mundo poco preocupado por el saber académico, y en 
el que la mayoría de las gentes eran analfabetas (Alexander-Bidon., Lett, 1997: 74 y ss; Bowen, 1985 II: 55). Durante la Alta Edad Media este tipo de educación servía únicamente para la preparación de clérigos y de otros religiosos, ya que las demás personas se instruían en sus propias familias (Becchi, 1998b I: 123). A partir de este momento, sobre todo después del siglo XI, la escuela procurará también una formación corta y elemental a los hijos de campesinos y de artesanos, basada en la lectura, la escritura ${ }^{20}$ y el cálculo, (Klaspich-Zuber, 1998: 238).

En estas escuelas se mezclaban niños y jóvenes de todas las edades, en correspondencia con un mundo, como el medieval, poco sensible a estas diferencias, que sólo adquirían significado, tal como se ha visto anteriormente, con respecto a la edad adulta (Ariès, 1987: 196; 208 y ss).

Las escuelas rurales fueron muy raras, al menos hasta el siglo XIII (Alexander-Bidon., Lett, 1997: 220). Habitualmente era el sacerdote quien abría una sala en el presbiterio para este cometido. Normalmente, los niños iban a la escuela en invierno, cuando no estaban ocupados en las tareas del campo (Riché.; AlexanderBidón, 1994: 130).

En los medios más humildes los padres dejaban a sus hijos a los monasterios para que fuesen alimentados y vestidos, al no poder ellos criarlos. En otros casos, como en el de los hijos de las familias nobles que no querían dividir excesivamente su patrimonio, o en el de las hijas destinadas a un convento, esta entrega se hacía en forma de donación (Pastor, 1986: 90). La vida monástica de esta infancia transcurría, bajo la vigilancia de un monje, integrada en el orden disciplinario conventual, estructurado en tiempos para el estudio, la práctica religiosa y las tareas domésticas, dejando también espacio para el juego. En cualquier caso, sus jornadas se desenvolvían entre los adultos que los observaban (Becchi, 1998b I: 121 y ss; Riché.; Alexander-Bidón, 1994: 119-120).

A partir del siglo X surgirán las denominadas escuelas catedralicias, en las que estudiaban los jóvenes que pretendían convertirse en clérigos (Bowen, 1985 II: 74 y ss). En el siglo XII aparecen las escuelas parroquiales destinadas a los hijos de los mercaderes y artesanos que aprendían allí a leer, a escribir y a calcular (AlexanderBidon., Lett, 1997: 84-85 y 220).

Por esta misma época emergen también las escuelas monásticas, en las que, junto con los que serán futuros clérigos, aprenden los demás niños conocimientos básicos de tipo técnico, tales como saber leer, escribir y contar, y también enseñanzas religiosas con un fuerte contenido moral (Becchi, 1998b I: 124; Riché.; Alexander-Bidón, 1994: 108 y 140 y ss).

$20 \quad$ No obstante, la enseñanza de la escritura estaba normalmente reservada a aquellos que iban a desempeñar funciones de escribanos (Becchi, 1998b I: 124). 
Por lo que respecta a los hijos de la nobleza, normalmente adquirían los conocimientos del alfabeto y del silabario a la edad de 5 o 6 años a través de un preceptor (Becchi, 1998b I: 123; Alexander-Bidon., Lett, 1997: 84-85 y 206 y ss). Al margen de esta instrucción escolar, su educación y su socialización dependían fundamentalmente, como antes se ha dicho, del medio familiar, así como de los preceptores, que completaban aquella educación preparando al joven para su incorporación definitiva a la vida adulta.

Toda esta realidad irá cambiando entre finales de la Edad Media y comienzos de la Moderna, alrededor del siglo XV, cuando los Colegios, vinculados a las instituciones religiosas, se convertirán en centros de enseñanza para los hijos de la nobleza (Ariès, 1987: 239 y 275).

En suma, la formación escolar, por lo general breve y rudimentaria, estuvo durante la Edad Media más vinculada a la instrucción que a la educación; por ello, como ya se ha señalado, tuvo un carácter secundario con respecto a aquella otra educación más densa, basada en la convivencia y en el ejemplo, que ofrecían las redes familiares y comunitarias, vinculadas a los diferentes órdenes sociales.

\section{ConcLusión}

La mentalidad educativa medieval integró, tal como se ha señalado anteriormente, la tradición greco-latina y la cristiana. De este modo, aunque en muchos aspectos supuso una continuidad con respecto a aquella tradición, en otros se apartó de ella. Tal es el caso de la menor potestad otorgada a los padres con respecto a sus hijos, que en el mundo romano era casi absoluta; o de una mejor consideración de la naturaleza infantil, que convivía con aquella otra procedente de la tradición clásica que sospechaba de ella. El recién nacido tenía así, en virtud de su débil integración en el mundo, la doble condición, de ángel y de demonio. Ángel, porque aún no había sido contaminado por los males del mundo; demonio, ya que, precisamente por este hecho, y por llevar grabado el sello del pecado original, era un ser potencialmente peligroso, por su carácter impetuoso e irracional.

Este carácter ambiguo era, para la mentalidad medieval, inherente a la infancia y a la juventud, y aunque después de la entrada en la edad de la razón se mitigaba, persistían aquellos impulsos irracionales siempre latentes para quienes no habían alcanzado todavía la etapa adulta, verdadero modelo y meta de la vida. Entre los adultos se educaban, pues, niños y jóvenes, integrados en un mundo que no les reservaba ningún espacio propio, sino era en medio de sus mayores. En compañía de ellos iban adquiriendo, mediante la palabra y el ejemplo, aquellos saberes y aquellas prácticas consideradas apropiadas para integrarse en el mundo. En el 
de la nobleza o en el de los campesinos, o en el del gremio en el que se comenzaba el aprendizaje de un oficio. Pero este aprendizaje iba mucho más allá de la adquisición de determinadas capacidades y habilidades técnicas. Suponía ante todo la socialización y la integración en un universo socio-moral bajo la égida de los adultos, quienes lo transmitían. Una trasmisión que se realizaba fundamentalmente a través de la observación, la palabra y el ejemplo en los distintos escenarios sociales en los que niños y jóvenes estaban permanentemente mezclados con los adultos. De ahí que la enseñanza escolar tuviese una escasa importancia, excepto para los que querían dedicarse al sacerdocio. En una sociedad en donde casi todo el mundo era analfabeto, los conocimientos necesarios para integrarse en el mundo se adquirían, en efecto, fuera de la escuela.

Esta forma de entender la educación permaneció básicamente inalterada más allá de la Edad Media, lo que no impidió el desarrollo gradual de un nuevo pensamiento educativo protagonizado por teólogos y filósofos. El Medievo legó a este pensamiento una concepción del alma infantil vinculada a la idea cristiana de pureza. Con arreglo a esta idea, se consideraba que la naturaleza infantil era buena y estaba llena de posibilidades. En un principio esta mentalidad convivirá con aquella otra que afirmaba justo lo contrario, su potencial maldad, y la consiguiente necesidad de integrarla en el mundo. Más tarde se abadonará progresivamente esta consideración permaneciendo la primera, conforme a la cual se establecerá la necesidad de mantener a la infancia alejada de un mundo social al que se percibía como la fuente primera de todas las corrupciones.

Ahora bien, esta nueva concepción de la naturaleza humana no penetrará la sensibilidad de los distintos grupos sociales hasta comienzos del siglo XVIII, cuando la burguesía se verá influenciada por muchos de sus principios (Robertson, 1994; Cook, 2004; Stone, 1990). Hasta ese momento, como luego se verá, la educación continuó por los cauces trazados anteriormente, al margen de aquellos pocos intelectuales, y de aquella escasa parte de la población integrada en el mundo académico, que comenzaba a entrar en contacto con las nuevas ideas educativas que se irán difundiendo, sobre todo a partir del siglo XV. 


\section{CAPÍTULO III \\ LA EDUCACIÓN EN LA SOCIEDAD DEL ANTIGUO RÉGIMEN}

Todos ellos querrían "introducir a los muchachos en la vida", como lo expresa Erasmo. Pero lo que aquí se entendía por vida de un modo inmediato, era precisamente la vida de los adultos. En las épocas posteriores se desarrolló cada vez más la tendencia a decir y a mostrar a los niños cómo debían y cómo no debían hacerlo. En la época de Erasmo, en cambio, con el fin de introducir a los niños en la vida, se les mostraba cómo debían comportarse los adultos y cómo no debían hacerlo (Elias, 1993: 214).

\subsection{CORTESÍA Y CIVILIDAD: LA ENSEÑANZA DE LAS BUENAS COSTUMBRES Y DE LAS BUENAS LETRAS}

A partir sobre todo del siglo XV se va imponiendo en el ámbito de la nobleza, que poco a poco dejará de ser guerrera para convertirse en cortesana, la necesidad de adquirir otros conocimientos, otras actitudes y otras prácticas mucho más acordes con su nueva condición (Julia, 1998: 351). Todas estas actitudes y prácticas integrarán un nuevo concepto de virtud que se apartaba radicalmente de aquel otro que había imperado durante la Edad Media, y que se identificaba con la nobleza caballeresca. La importancia de esta nueva forma de virtud frente a la anterior aparece muy claramente reflejada en uno de los más importantes libros de cortesía del primer tercio del siglo XVI, el Galateo de Giovanni Della Casa:

Deseamos ser corteses, agradables y educados en nuestra conversación y en nuestro trato con los demás. Si esto no es virtud, no está muy alejado de ella. Pues, aunque la generosidad, la lealtad y la valentía moral son sin duda cualidades más nobles y más dignas de elogio que el encanto y la cortesía, los hábitos corteses y una forma correcta de hablar y comportarse pueden beneficiar a quienes los poseen en no menor medida en que un espíritu noble y un corazón valiente benefician a otros (citado en Amelang, 1986: 111).

Esta nueva idea de virtud, que se difundió primeramente en las ciudades-Estado italianas del Renacimiento (Burckhardt, 2004; Amelang, 1986: 110-111), se asociaba, 
como se ve, con una serie de actitudes, comportamientos, gustos y saberes que podían ser adquiridos a través de la educación humanista y en artes liberales. Aunque este nuevo ideal no se oponía al linaje, se vinculará cada vez más al tipo de educación que debían poseer quienes fuesen dignos de considerarse civilizados. "Y tengo yo en más ser bien educada que bien nacida; mucho más precio nobleza de costumbres que de linaje", dice uno de los personajes de los Coloquios de Erasmo (Erasmo, 2005: 212). Si bien la nobleza de estirpe continuará siendo uno de los principales signos de la identidad aristocrática, la buena crianza, que descansaba en el aprendizaje de las letras y las artes liberales, en la medida en que era parte fundamental de aquella identidad, se convertirá asimismo en un medio principal para aquellos que ambicionaban progresar en la sociedad (Amelang, 1986: 162 y ss).

En un principio, entre la segunda mitad del siglo XV y la primera del XVI, la nobleza se definirá aún a partir de la mezcla entre las formas caballerescas y las que proponía el humanismo cortesano (Burckhardt, 2004: 329). Así, podemos leer en el Gargatúa y Pantagruel de François Rabelais (1530) que los habitantes de la abadía de Thélème "estaban instruidos de un modo tan superior, que no había entre ellos nadie que no supiera leer, cantar, tocar instrumentos musicales, hablar cinco o seis lenguas y componer en éstas, tanto en verso como en prosa”. Pero, al lado de estos conocimientos, poseían también aquellos thélemitas otros saberes y otras actitudes dignas de todo caballero. "Jamás se han visto- prosigue Rabelais- caballeros tan gentiles, tan diestros a caballo y a pie, tan lozanos, tan bulliciosos, que manejarán mejor todas las armas como los que allí había" (Rabelais, 1971: 204).

A medida que trascurra el tiempo se irán imponiendo, sin embargo, cada vez más los comportamientos, las actitudes y los conocimientos vinculados al humanismo cortesano, que se ajustaban mucho más a la identidad de una nobleza que iba dejando las armas para abrazar las letras (Taylor, 2006: 50). Pero incluso aquella parte de la nobleza que se incline por las armas al servicio de la realeza, tendrá que poseer también los comportamientos y los ademanes corteses y civilizados. Así se ponía de manifiesto en los consejos que en 1647 recibían dos jóvenes nobles germanos, uno de los cuales se había decidido por la milicia. A ellos se recomienda que "traten con todos civilizada y modestamente, absteniéndose del juego y de cualquier otra cosa en la que pueda haber sombra de vicio, empleándose (...) en sus estudios militares, matemáticos y caballerescos” (citado en Ago, 1996: 382).

El nuevo ideal de civilidad se había impuesto, como se ve, como principal seña de identidad de la nobleza. Ideal que por ello debían adquirir e interiorizar tanto adultos, como niños y jóvenes de noble linaje. "Y así los que quieran bien criar a los niños- se dice en uno de los más famosos libros de cortesía del siglo XVI- no solamente les muestran letras, más aún les avezan a que sepan tener buena manera y honesta en el comer y beber y hablar y andar con buen aire y con ademán con- 
forme a lo mejor" (Castiglione, 1994: 461). Cómo caminar, qué postura corporal adoptar, cómo gesticular; cuándo y cómo hablar con los demás; qué libros leer y qué obras de arte admirar; y también como escribir, porque la escritura, y particularmente la epistolar, desempeñará un papel fundamental para consolidar y alimentar las relaciones sociales (Julia, 1998: 357-358). Todo esto, en efecto, ha de ser aprendido por el cortesano, que para su nueva función necesita ser agradable, sociable y persuasivo con aquellos que detentan su misma condición social (Taylor, 2006: 50-51; Burckhardt, 2004: 313 y ss).

No hay aquí, como se ve, ninguna diferencia relevante entre gente instruida y bien educada; entre quienes son hombres de letras y asimismo corteses y civilizados. Todo este acervo se integrará en un mismo programa, el que los humanistas, y después las órdenes religiosas de la Contrarreforma, pondrán al servicio de la nueva nobleza. En efecto, la instrucción en las buenas letras, si no está vinculada a la sociabilidad cortesana que la justifica, apenas tendrá sentido.

Para desarrollar apropiadamente todas estas capacidades y habilidades, el habitus apropiado a la nueva condición social, se requería, pues, de un nuevo tipo de educación. De esta necesidad era plenamente consciente el arquitecto y humanista italiano del siglo XV, Leon Battista Alberti, que en su tratado sobre la familia mostraba claramente cuáles habían de ser los modos y las actitudes apropiados a la infancia cortesana. "Un niño- escribe- que está presto a responder, deseoso de mezclarse con los demás, sin rudezas, sin miedo, sin torpezas, demuestra que está listo para afrontar la batalla de la vida" (citado en Julia, 1998: 248). Esa batalla en la que se integrará en su etapa adulta, y para la cual ya no valían las armas que emplearon sus antepasados, sino estas otras que señala Alberti. La corriente humanista atenderá a este nuevo propósito, ofreciendo un tipo de literatura que servía de modelo para las nuevas formas de sociabilidad que se estaban imponiendo entre la nobleza cortesana (Elias, 1993a: 211 y 486; Garin, 1987: 132). Entre esta literatura cabe destacar, por la gran difusión que tuvieron, los tratados de buenas maneras, tales como El Cortesano de Baltasar de Castiglione (1994), publicado en 1528; o el Galateo de Giovanni della Casa, aparecido en 1558 (2003). Ambas obras alcanzaron una gran popularidad, porque entroncaban con lo que demandaba la nobleza para construir su nueva identidad ${ }^{21}$ (Garin, 1987: 136-137).

Todo este proceso de aprendizaje y de socialización produjo una nobleza orgullosa de sus propios códigos de comportamiento, considerados primero corteses

${ }_{21}$ Tanto uno como otro libro gozaron de una amplia popularidad. El Cortesano de Castiglione se difundió por toda Europa, y de él se hicieron numerosas imitaciones (Amelang, 1986: 111). En cuanto al Galateo de Della Casa llegó a ser uno de los textos obligatorios en los colegios europeos, como los de los Jesuitas. Por ello, tuvo varios imitadores en otras lenguas, como el Galateo español, cuyas primeras ediciones son de 1593, y del cual se hicieron 24 ediciones más entre esta última fecha y 1796 (prólogo a Della Casa, 2003: 34 y 95; Ariès, 1987: 499). 
y después civilizados (Elias, 1993a). Dichos códigos se convertirán en sus principales signos de distinción, por medio de los cuales actuaba y se sentía parte de una categoría superior. Frente a estos códigos, las actitudes y los comportamientos del pueblo llano serán calificados de burdos y ordinarios (Amelang, 1986: 164). "Pero no por eso quiero que te pongas a hablar tan trivialmente como la escoria del populacho y como la lavandera o la verdulera, sino como los gentilhombres", se dice en el Galateo (Della Casa, 2003: 203). En el mismo tono se pronuncia un personaje de los Coloquios de Erasmo: “¿Para qué me alegas con el vulgo- dice- cuyo testimonio para ninguna cosa buena vale nada, cuyas costumbres por la mayor parte son maestras de toda maldad" (Erasmo, 2005: 173). Y en El Cortesano se puede leer: “...no sería cosa convenible que un caballero fuese a honrar con su persona una fiesta o boda de aldeanos, adonde los que mirasen y los que con él viniesen fuesen hombres baxos" (Castiglione, 1994: 221). Este rechazo de las formas de hablar, de los comportamientos y de las actitudes del vulgo por parte de esta nueva aristocracia, irá seguido más tarde de su retirada progresiva de los escenarios en donde el pueblo llano celebraba y se divertía (Taylor, 2006: 61 y ss; Amelang, 1986: 187 y ss).

En suma, frente a las personas rudas de baja condición, que se dejan dominar por su naturaleza pasional, los humanistas elevarán al hombre educado, culto y civilizado, como la más alta expresión del ser humano; el espejo en el que habían de mirarse todas las demás gentes (Zweig, 2005: 106).

Este nuevo ideal de la civilidad, que se podía aprender en los libros de cortesía, y que se interiorizaba en el mundo de la sociabilidad cortesana, exigía también una nueva formación académica, destinada a reprimir todo lo que de más impulsivo se consideraba que había en la naturaleza humana. Esta formación es la que proporcionarán las instituciones escolares nacidas en el contexto de la Contrarreforma, y en especial los colegios de los Jesuitas (Varela, 1991: 64). En ellos se adquiría la erudición humanista apropiada a esta nueva condición social. De este modo el humanismo, y las instituciones religiosas que en él se inspiraron, contribuyeron a crear una pedagogía a la medida de las distintas edades que inaugurará una nueva manera de entender la educación. No obstante, al margen de estas instituciones, o, dicho con más precisión, de algunas de ellas, continuó todavía durante mucho tiempo la costumbre de que la infancia y la juventud convivese y se socializase al lado de los adultos en los mismos escenarios sociales.

\subsection{INFANCIA, JUVENTUD Y EDAD ADULTA}

Como anteriormente se ha señalado, el mundo cortesano exigía una nueva educación que debía de ser adquirida desde la infancia. Se fue así creando, gradualmente, un espacio educativo apropiado a esta edad, a la que había que inculcar 
convenientemente todos los conocimientos, los comportamientos y las actitudes vinculados a la nueva sociabilidad. Para ello, era preciso emprender una intensa labor, dirigida primero a que los niños supiesen dominar sus impulsos, y después a que interiorizasen los códigos sociales y morales apropiados a su condición. Todo lo cual producirá un nuevo interés por la infancia, interés que hará crecer la distancia entre ella y el mundo adulto. En efecto, a medida que los adultos interioricen las formas y las normas de la vida consideradas civilizadas, más se reprimirá en los niños aquellos comportamientos que las infringen (Elias, 1993a: 207-208).

Esta nueva atención, que poco a poco va mereciendo la infancia, comenzaba ya a advertirse a finales de la Edad Media, entre los siglos XIV y XV. De acuerdo con esta mentalidad, era posible observar en algunas imágenes funerarias a la infancia representada en sus justas proporciones, y separada de los adultos; mientras que en la etapa anterior se representaba rodeada de su familia, como si tratase de adultos en miniatura (Becchi, 1998c: 172-174; Ariès, 1987).

No obstante, por el momento, todo esto no conducirá a la creación de un mundo infantil estructurado según su propia lógica, porque el modelo a imitar continuaba siendo el de la denominada edad madura. Esa edad considerada, siguiendo la tradición clásica, la más templada, "porque- se afirma en el Cortesanoya dejó las malas condiciones de la mocedad y no ha llegado aún a las de la vejez" (Castiglione, 1994: 229).

No había, por ello, todavía una clara voluntad de separar las distintas edades. Más bien, todas ellas aparecían mezcladas en los diferentes escenarios en los que trascurría la vida social, y particularmente en la calle (Becchi, 1998c: 190; Ariès, 1979; 1987: 434 y ss). Además, los límites entre las distintas etapas de la vida eran poco claros, porque dependían del momento en el que uno ingresaba en aquellos universos sociales que marcaban el final de una etapa y la entrada en otra (Schindler, 1996: 311).

Tampoco se tenía aún la conciencia de que el mundo exterior estaba lleno de peligros para la infancia, y en consecuencia tampoco se percibía la necesidad de recluirla en su propio ámbito (Becchi, 1998c: 180). Tal ámbito todavía no existía, ya que la meta de la vida era la futura integración en el mundo adulto.

Por este motivo, en los libros que comenzaron a proliferar a partir del siglo $\mathrm{XV}$, algunos de los cuales tuvieron una gran notoriedad en el XVI, se ponían como ejemplo diferentes escenas de la vida adulta, a pesar de que estaban dirigidos a la educación de la juventud. Entre ellos cabe destacar, por la popularidad que alcanzaron, dos obras de Erasmo: Civilitate morum puerilium, publicada originalmente en $1530^{22}$ (Erasmo, 1985), y los Coloquios (Erasmo, 2005), redactados, según pare-

22 De esta obra se acabaron imprimiendo en 1530, primer año de su publicación, 12 ediciones (Garin, 1998: 293). 
ce, en una fecha anterior a 1500 (Huizinga, 1987 II: 276), pero cuya primera edición data de 1518 $8^{23}$ (Augustijn, 1990: 179). En dichas obras se mostraban distintas escenas de la vida adulta, algunas moralmente apropiadas y otras contrarias a la moralidad. Sin embargo, tanto en uno como en otro libro apenas estaba presente la infancia (Augustijn, 1990: 180). Los ejemplos que se proponían provenían en su mayoría, por el contrario, del mundo adulto. Así se puede apreciar en diversos pasajes de los Coloquios de Erasmo, como les que se muestran a continuación. "Siempre he oído decir que la castidad es muy agradable a Dios", dice uno de los personajes de esta obra. "Entiéndelo de esta manera", responde el otro, "si abstenerse fuese en sí virtud, lo contrario sería vicio". “¿Cuándo acontece eso que dices?", observa el primero. “Todas las veces que el marido pide el débito jurídico a su mujer, si lo hace con intención de propagar el género humano". En otro lugar de estos mismos Coloquios se presenta una charla entre dos novios que se conduce en los siguientes términos: "la primicia de mi virginidad te guardo para cuando enteramente te la pueda toda entregar", dice la novia. "Si no disminuye, ¿quieres que se la dé a cuantos me la demandaren?", prosigue. "En ninguna manera", contesta el novio, "antes quiero que toda la guardes para mí. Pues para ti la guardo", responde la novia (Erasmo, 2005: 214-215; 217-218).

Ejemplos como estos eran elegidos con la intención de mostrar a la infancia y a la juventud lo bueno y lo malo que había en el mundo, con la finalidad de que actuasen juiciosamente en él cuando alcanzasen la edad adulta (Elias, 1993a: 214215). El libro- escribió Erasmo en la introducción a la edición de los Coloquios de 1524- "ha contribuido a que muchos sean mejores latinistas y mejores hombres" (citado en Augustijn, 1990: 182).

Ahora bien, que el mundo de los adultos fuese la medida de todas las cosas, tanto de las buenas como de las malas, y que todas las demás edades fuesen consideradas con respecto a ésta, no significaba que se reprimiesen todos los comportamientos infantiles y juveniles que no se acomodasen a dicho modelo. Si bien la infancia y la juventud despertaban numerosas sospechas como edades aún inmaduras y tendentes a la desmesura (Ago, 1996: 382), dicha desmesura era en ocasiones tolerada como la manifestación de un ciclo vital que habían de recorrer todas las generaciones antes

23 Aunque la primera edición de los coloquios fue la de Basilea de 1518, de la que Erasmo no supo nada en su momento, y que contenía, además, diversos errores. Posteriormente, y una vez que comprobó la popularidad de la que gozaba su libro, él mismo preparó otra edición en 1521, aparecida en Lovaina, y que también se hizo muy popular. Como populares fueron también las dos ediciones publicadas bajo su dirección en 1522. Buena prueba de la fama que tuvieron los Coloquios de Erasmo es que en 1522 contaban ya con 25 ediciones, y a la muerte de Erasmo se había llegado a las 100 (Huizinga, 1987II: 276). La influencia de esta obra fue tan grande que además de introducirse en los territorios católicos, y especialmente en Baviera, España y Portugal, penetró también en las zonas luteranas de Alemania (Augustijn, 1990: 179 y ss). 
de llegar a la edad madura. Todo ello se señalaba con diversos rituales, que jalonaban los diferentes momentos de la vida, y que, aunque tendían a subvertir el orden social con actos más o menos graves, eran, sino aceptados, al menos consentidos. Si por consentimiento se entiende una cierta inhibición de los adultos, que equivalía a una especie de guiño a los más jóvenes, a los que se permitía girar ritualmente la rueda de la vida, como antes lo habían hecho sus mayores, sabiendo, unos y otros, mayores y jóvenes, que su destino no podría ser otro que su integración final en el mundo de los adultos (Schindler, 1996: 330 y ss).

Esta actitud es la que empezará a cambiar a partir de finales del siglo XVIII, cuando comience a emerger la nueva sensibilidad burguesa replegada sobre la intimidad familiar (Anderson, 1988: 46). De acuerdo con esta nueva sensibilidad se procurará mantener a la infancia y a la juventud alejadas de las influencias del mundo adulto exterior, consideradas fuente de todo tipo de perversiones (Ariès, 1987: 528). Ya no se aceptarán entonces aquellos comportamientos que las sociedades preindustriales toleraban como parte del aprendizaje de la vida. Este aprendizaje comenzará a tener como modelo, ya no el mundo de la gente adulta, sino el de la propia infancia y la juventud. Por lo que serán reprimidas todas aquellas actitudes que se consideren contrarias a la nueva moralidad establecida.

A partir del siglo XVIII este cambio comenzará a ser visible en la intervención de las autoridades públicas, y también en la actitud de una serie de filántropos, psicólogos y moralistas, que perseguian apartar a dichas edades del espacio público de la calle. Un espacio que la naciente sociedad industrial percibía como el origen de todos los males, sociales y morales (Ariès, 1979). Con esta misma actitud moral, el reverendo Clyton mostraba en el siglo XVIII la inquietud que le producía ver como las calles de Manchester estaban pobladas de "niños harapientos sin nada que hacer, que no sólo pierden el tiempo- decía-, sino que aprenden costumbres de juego" (citado en Thompson, 1979: 276). Animadas por esta preocupación, las autoridades públicas pondrán así en marcha desde finales del siglo XVIII, y durante todo el siglo XIX, distintos programas dirigidos a erradicar a la infancia "vagabunda" que pululaba por las calles. Para lo cual se crearon escuelas caritativas de pobres y de beneficencia (Ariès, 1979 y 1987: 401). El medio escolar estará destinado, en efecto, a reformar las jóvenes conciencias en la dirección moral que precisaba el orden industrial. Un orden configurado a partir de la esfera productiva, pero que necesitaba también una específica forma familiar y escolar para institucionalizarse económica, social y morlamente.

Se irá así conformando la infancia escolarizada, socializada en su propio espacio, bajo reglas y normas apropiadas a su condición (Ariés, 1979). No obstante, esta infancia será muy residual a lo largo de todo el Antiguo Régimen, puesto que la mayoría de la población continuará otorgando poca importancia a la enseñanza escolar como medio para el aprendizaje y la integración social. 


\subsection{LA INFANCIA Y LA JUVENTUD ESCOLARIZADAS}

Una nueva visión de la infancia y de la juventud, en cuanto categorías de edad singulares y diferenciadas, irá emergiendo gradualmente a medida que progrese la difusión de los establecimientos escolares, y se vaya apartando a estas edades de los escenarios del mundo adulto (Ariès, 1987). Este hecho comienza a ser visible en el siglo XV, momento en el que irán apareciendo poco a poco en muchos lugares de Europa occidental colegios y escuelas latinas humanistas (Julia, 1998: 344). Entre los colegios alcanzarán una especial importancia a partir del siglo XVI los de los Jesuitas. En un principio estaban compuestos por clérigos; pero más tarde, a partir del siglo XVII, se abrirán también a laicos, tanto nobles como burgueses, e incluso a miembros de los grupos sociales más populares. En ellos se formaban las personas consideradas cultas en la sociedad del Antiguo Régimen, prácticamente todos varones, en un orden disciplinario, jerárquico, y que estructuraba con precisión tanto los tiempos como los espacios (Ariés, 1987: 234-238 y 337; Varela, 1984: 154-155). Allí, en los colegios, y particularmente en los de la Compañía de Jesús, no sólo se enseñará piedad, sino también buenas letras, en conformidad con lo que exigían las nuevas élites sociales cortesanas, preocupadas por formarse en todos aquellos saberes y comportamientos vinculados a su nueva identidad (Ago, 1996: 383). Para todo ello se tomará como modelo el humanismo de Erasmo, y asimismo el de Vives, pero también, en ocasiones, el de Rabelais y el de Montaigne ${ }^{24}$ (Demoustier y Julia, 1997: 14; Varela, 1984: 135 y ss). Modelo que se utilizará, asimismo, para aquellas otras cuestiones relacionadas con el método de enseñanza, que buscará, como proponían los humanistas, relacionarse con los niños de una forma más cercana y suave, mostrándoles asuntos y situaciones que no perturbasen su espíritu (Huizinga, 1987 II: 198). Este programa educativo, basado en el aprendizaje del latín y del arte del bien hablar y escribir, y que utilizaba como fuentes, tanto los textos de los autores clásicos de la antigüedad como los de los humanistas, entroncaba, como se ha dicho, con la nueva sensibilidad de la nobleza cortesana, pero también con las aspiraciones de ascenso social de la naciente burguesía, deseosa de imitar a aquella nobleza más relacionada con las letras que con las armas (Varela, 1991: 67).

Aquí, en los colegios, y sobre todo en los de los Jesuitas, es donde primero comenzarán a estructurarse las clases por categorías de edad, rompiendo así gradualmente con la costumbre medieval de reunir a la infancia y a la juventud en un

${ }^{24}$ Si bien es cierto que los Jesuitas no recibieron siempre bien las obras de algunos de los principales humanistas, y en especial las de Erasmo, algunas de las cuales fueron, en ocasiones, prohibidas. No obstante, apreciaron los saberes humanistas, con el gusto por la lengua latina, la escritura y la oratoria; y también el modo de transmitir todas estas enseñanzas, de una forma tierna y suave (Varela, 1984: 135-136). 
mismo lugar. Se iniciará así un proceso que conducirá a la separación progresiva de las distintas edades. Proceso que coincide con la difusión del concepto de la buena educación vinculada a la infancia, que se había ido desarrollando en el siglo y medio anterior por los filósofos y moralistas pertenecientes a la Iglesia y al Estado (Ariés, 1987: 432 y ss).

No obstante, ni en el siglo XVI, y ni siquiera tampoco en el XVII, este proceso de separación de las edades se había, ni mucho menos, consumado; si bien, tal como se ha señalado, ya había comenzado (Varela, 1991: 74). Todavía no existía, en efecto, un sistema escolar debidamente estructurado por grados y por edades, por lo que no era extraño ver a estudiantes de distintas edades mezclados en los mismos cursos escolares, como tampoco lo era el que se incorporasen tarde al ciclo escolar. Quizás por ello los límites entre la infancia y la juventud resultasen algo difusos (Schindler, 1996: 311). A esta realidad sólo escapaban los colegios de la Compañía, tal como lo señalaba el Jesuita español Ribadeneira, en su Vida de San Ignacio, publicada por primera vez en 1573:

En otras escuelas- escribe- un mismo maestro tiene diferentes órdenes de discípulos: menores, medianos, mayores; y queriendo acudir a todos no puede cumplir con lo que cada orden ha menester. Más la Compañía tiene sus discípulos separados y apartados en sus clases, y para cada una de ellas su particular y señalado maestro (citado en Varela, 1991: 64).

Ahora bien, los progresos que en este aspecto representaron los colegios de Jesuitas no acabaron con la costumbre de mezclar las edades, que, como antes se ha indicado, permaneció vigente, al menos hasta el siglo XVIII (Ariès, 1987).

En efecto, la mayoría de las instituciones escolares no tenían inconveniente en reunir a distintos tipos de alumnado, tanto desde el punto de vista de sus edades como del medio social al que pertenecían. Con relación a esta última cuestión, las Escuelas de Beneficencia, por ejemplo, en un principio destinadas a niños pobres, acabaron, a partir de finales del siglo XVII, acogiendo también a los que tenían más recursos, tales como algunos hijos de artesanos, comerciantes y burgueses (Becchi, 1998c: 183; Ariés, 1987: 410 y ss; Bowen, 1985 III: 197). El que fuesen de beneficencia no generaba, en efecto, ningún rechazo en estos grupos sociales, en unas sociedades como las estamentales en las que las posiciones estaban bien definidas y afirmadas por la tradición, por lo que las gentes más acomodadas no veían su estatus comprometido por esta razón. Lo mismo se puede decir de las Escuelas Menores, que se desarrollaron también en el siglo XVII, destinadas fundamentalmente a la infancia, de entre cinco y siete años, perteneciente a los sectores populares, pero en las que no se excluía tampoco a otras edades y a otras categorías sociales. Y esto, que era verdad para la primera etapa de la enseñanza, lo era también para los colegios, destinados en un principio a los hijos de la nobleza 
y de la burguesía, pero que no rechazaban tampoco a los grupos sociales más populares que buscaban de este modo un cierto ascenso social. Ascenso que se podía lograr accediendo a los cargos administrativos que ofrecía un Estado monárquico en expansión, para lo cual era imprescindible disponer del tipo de formación que ofrecían los colegios, y en especial los de los Jesuitas (Varela 1984: 164 y ss). Aun así, lo más frecuente era que muchos de estos alumnos abandonasen el colegio una vez realizados los primeros cursos, para integrarse en el mundo militar o en algún oficio manual.

La razón de esta actitud tan permisiva con respecto a la mezcla de las edades y de los grupos sociales, obedecía a que los sectores más privilegiados, seguros como estaban de su posición social, no se sentían por este motivo amenazados. Aunque esta mezcla también se explicaba por la pretensión de las élites políticas y eclesiásticas de moralizar y de proporcionar un oficio a los hijos de los sectores populares (Ariés, 1987: 410 y ss).

No obstante, a partir del siglo XVIII, esta mentalidad irá cambiando, de tal forma que la separación por grupos de edad y por clases sociales será un hecho cada vez más generalizado. Surgirá así una enseñanza a la medida de los sectores populares, como instrumento para el desempeño posterior de los distintos oficios; y otra, la secundaria, destinada a las élites aristocráticas y burguesas (Ariés, 1987: 413-414) “¿Por qué los niños- escribía el cardenal Bernis en sus memorias-, no siendo todos de la misma condición social, ni destinados a los mismos empleos, están sometidos a la misma educación? ¿No sería mejor- decía- enseñarle aritmética al hijo del comerciante, por ejemplo, en lugar de enseñarle a componer versos griegos y latinos?" (Citado en Ariés, 1987: 410). Dicha mentalidad, contraria a la progresión escolar de los grupos populares, respondía, asimismo, al temor que tenían las élites políticas y sociales a que la instrucción del pueblo pudiese despertar en él algún tipo de ansias revolucionarias (Ariés, 1987: 407 y ss).

Hasta el siglo XVI lo más frecuente era que la mayoría de los jóvenes no completasen el ciclo escolar. Es más, una gran cantidad de ellos eran analfabetos, en una sociedad en las que los concomimientos prácticos necesarios para el desempeño de determinados oficios se aprendían por lo general en el mismo lugar de trabajo, bajo la dirección de los adultos (Becchi, 1998c: 190). Con respecto a los demás jóvenes que terminaban el periodo escolar, lo más habitual era que ingresasen como aprendices en una casa noble, o en una actividad comercial o artesanal (Ariés, 1987: 275).

Entre las familias nobles se extendió también la costumbre, particularmente durante el primer tercio del siglo XVII, de enviar a sus hijos, una vez terminada la etapa escolar, a las denominadas Academias, en donde recibían formación escolar y militar (Ago, 1996: 383). Por lo demás, siguió perviviendo entre estas mismas 
familias la tradición de mandar a sus hijos a casa de otro noble amigo, que actuaba como preceptor. Es más, en algunos lugares, como España, este tipo de enseñanza a cargo de un preceptor continuó siendo la predominante entre la aristocracia, al menos hasta mediados del siglo XVII (Amelang, 1986: 157). A partir del siglo XVI, lo más frecuente era que estas casas estuviesen situadas en el extranjero (Ariés, 1987: 275).

Frente a este tipo de educación, que descansaba en una intensa socialización basada en la experiencia y en la observación, los medios escolares se esforzaron en señalar la importancia de sus enseñanzas, alejadas de la vida social, y por tanto también de toda mala influencia. De todos modos, la nobleza siguió con su antigua costumbre de educar a sus hijos por medio de preceptores, completando, eso sí, esta educación con aquella otra proporcionada por los colegios, que se había hecho cada vez más imprescindible para adquirir los conocimientos y los comportamientos apropiados a su nueva identidad cortesana (Ago, 1996: 383 y ss). Aun así, todavía se escuchaba decir a mediados del siglo XVII al mariscal de Caillière que "no es suficiente ser docto en la ciencia del colegio; hay otra ciencia- afirmaba- que no utiliza ni el griego ni el latin, que nos enseña cómo hay que ser y que nos indica el uso de ambas lenguas. Esta ciencia tiene por guía la prudencia y por doctrina la conversación y la experiencia" (citado en Ariès, 1987: 502).

Sólo una reducida minoría perteneciente a las élites sociales llegaba a la universidad, después de haber terminado sus estudios en los Colegios. En el caso de la nobleza, esta minoría estaba compuesta habitualmente por los segundones, aquellos que, por no gozar de derechos de primogenitura, tenían que mantener su posición a través de las posibilidades que le otorgaban los títulos universitarios, por lo general en teología o en derecho, para comenzar así una carrera en el ámbito eclesiástico o en el de la administración del Estado (Ago, 1996: 384; Varela, 1991: 63; 1984: 104 y ss).

El mundo universitario no era precisamente un remanso de paz, sino el escenario de numerosas algaradas y violencias de distinto tipo, que desembocaban, no tan raramente, en auténticos motines protagonizados por estudiantes, que normalmente portaban armas. "El estudiante de artes- afirma el canciller Prevostin en un pasaje citado por Durkheim- pasa la noche completamente armado en las calles, rompe las puertas de las casas, llena los tribunales con los ruidos de sus escándalos" (Durkheim, 1992: 157-158). Esto, que ocurría en Francia, se repetía también en Inglaterra y en España, en donde este tipo de escenas fueron relativamente frecuentes. En este último país los desórdenes se fueron reduciendo a partir de mediados del siglo XVI, a medida que iban surgiendo los Colegios Universitarios que reglamentaban la vida estudiantil (Varela, 1984: 105 y ss). En Francia, hubo que esperar a la segunda mitad del siglo XVII para que esto ocurriese (Ariès, 
1987: 415 y ss); aunque ya mucho antes, a mediados del siglo XV, las autoridades universitarias establecieron, con el ánimo de reducir los motines y las algaradas estudiantiles, que los estudiantes estuviesen internados en los Colegios o en las casas de sus padres, bajo pena de no otorgar certificados de estudios (Durkheim, 1992: 158). En Inglaterra esta situación no cambió, según parece, hasta el siglo XVIII, momento a partir del cual se redujo la conflictividad estudiantil (Ariès, 1987: 415 yss).

No es de extrañar, pues, que en estas circunstancias la juventud universitaria fuese percibida por las gentes de la época con bastante desdén, y situada al lado de aquellas otras personas a las que se atribuía una vida poco honrada y disoluta. No obstante, este comportamiento no era exclusivo del mundo estudiantil, ya que la sociedad en general resolvía sus diferencias a través de la violencia (Taylor, 2006: 54; Ariès, 1987: 415 y ss).

Aunque la nobleza fue perdiendo sus impulsos guerreros bajo la presión de las monarquías absolutas, que acabaron sometiéndola y poniéndola a su servicio, se trató de un proceso gradual que no estuvo exento de resistencias. En efecto, a lo largo del siglo XV, y durante la primera mitad del XVI, la nobleza de armas no había cedido todavía ante la de letras; y tampoco sus descendientes más jóvenes, que aún participaba de la identidad caballaresca, aunando los valores de las armas y los de las letras. Por eso, los poderes monárquicos, ya plenamente asentados en el siglo XVI al frente de los nuevos Estados, detentando por ello el monopolio de la violencia, tendrán el máximo interés en desarmar a todos aquellos nobles que osasen perturbar la paz interna sin su consentimiento (Taylor, 2006: 53; Varela, 1984: 111 y ss). No había, pues, otro camino que ponerse al servicio de estos nuevos poderes, bien al mando de sus ejércitos, o desempeñando los más altos cargos de un aparato administrativo que no dejaba de expandirse. La nobleza estudiantil no tendrá así más remedio que apartar las armas y abrir su camino sólo a las letras. Cosa que será cada vez más evidente a partir de la segunda mitad del siglo XVII ${ }^{25}$.

En resumen, la enseñanza escolar, aunque fue adquiriendo un mayor peso a lo largo del periodo del Antiguo Régimen, era, tal como se ha mostrado, corta y poco importante para la mayoría de la población. Sólo aquella minoría perteneciente a las élites sociales, prolongaba su educación en los colegios, siendo muy pocos los que iban a la universidad a estudiar, fundamentalmente teología o leyes. Frente a esta enseñanza, más formal y estructurada, que tendía a separar a la infancia y a la juventud de la esfera del mundo adulto, la mayor parte de los conocimientos se adquirían a través de la inmersión en el propio universo social en el que desenvol-

25 De todos modos, todavía en 1644 se produjeron en Salamanca graves conflictos callejeros protagonizados por estudiantes de la universidad, en los que hubo varios muertos (Varela, 1984: 106). No obstante, toda esta situación será cada vez más un recuerdo del pasado. 
vían su vida los adultos, siguiendo su práctica y su ejemplo (Schindler, 1996: 311). En este contexto, la instrucción y la educación estaban íntimamente unidas, pues ambas formaban parte del mismo proceso de socialización, por medio del cual se interiorizaban saberes y prácticas; sentimientos y actitudes.

\section{Conclusión}

Hasta aquí se ha mostrado cuáles fueron las formas, los contenidos y el significado de la educación en las sociedades del Antiguo Régimen, que en muchos aspectos supusieron una continuación con respecto a las medievales, pero que en otros se apartaron abiertamente de aquellas.

Se apartaron en la medida en que se vincularon a los modos de socialización de un nuevo grupo social, la nobleza cortesana, que precisaba de la palabra, principalmente oral, pero también escrita, así como de una serie de actitudes y de formas de comportamiento para construir su nueva identidad. Todo lo cual requería un nuevo tipo de educación relacionada con las categorías de lo cortés y de lo civilizado, que se habían construido en el ámbito de los nuevos estados renacentistas, y que serán teorizadas y difundidas por los principales pensadores humanistas.

Estas categorías acabarán por producir diferencias cada vez más marcadas entre gentes corteses y civilizadas; entre las que dominan el lenguaje y las formas en el trato apropiadas a su condición social, y aquellas otras cuyos comportamientos y actitudes se consideraban vulgares, groseros y rudos. Diferencias que separarán, asimismo, cada vez más a la infancia y a la juventud de la edad adulta. Estas edades se verán así obligadas a reprimir las formas que sus mayores consideraban inapropiadas, por incivilizadas, y a interiorizar, por el contrario, las que se entiendía que eran civilizadas. Se creará así todo un programa educativo, inspirado en el humanismo, enfocado a la formación de la infancia y la juventud de noble linaje. Un programa que se encargarán de poner en práctica las instituciones educativas de la Contrarreforma. Emergerá de este modo una nueva concepción de la infancia, objeto de una creciente preocupación, a la que se procurará alejar cada vez más de aquellas influencias del mundo adulto, consideradas perversas. A este alejamiento contribuirá sustancialmente el medio escolar, por su tendencia a distanciar a estas edades de los espacios de interacción de sus mayores y por su creciente inclinación a estructurar los cursos escolares a partir de las diferencias de edad.

No obstante, por el momento todos estos cambios, que anunciaban la sociedad venidera, no se extenderán a la mayoría de los grupos sociales que conformaban la sociedad del Antiguo Régimen. Sólo una minoría privilegiada, perteneciente a la nobleza y a la emergente burguesía, pudo verse afectada por ellos; $\mathrm{Y}$ aun así 
continuaron teniendo vigencia muchos de los usos y de las costumbres aceptados tradicionalmente. Usos y costumbres que irán perdiendo vigor a medida que la burguesía vaya imponiendo los suyos, más en consonancia con la naciente sociedad industrial.

Pero hasta que esto suceda continuará imperando la mentalidad, arraigada en el pasado, que consideraba a la edad madura, aquella que se alcanzaba una vez finalizada la juventud, como el modelo que servía como ejemplo a los anteriores periodos de la vida. La vida social se desenvolvía así en un escenario en el que se mezclaban las distintas edades, participando infantes y jóvenes de un mundo que más tarde sería el suyo. Esta profusión de las edades tampoco era extraña al medio escolar, en el que las reformas en la dirección contraria fueron lentas, si exceptuamos las que emprendieron las instituciones de la Contrarreforma, y en particular los colegios de los Jesuitas. De todos modos, la enseñanza escolar, aunque fue ganado un mayor protagonismo a lo largo del Antiguo Régimen, a medida que era cada vez más necesaria para la nobleza palaciega y para los demás grupos sociales en ascenso, tuvo una importancia secundaria, salvo para los miembros de las élites que aspiraban a altas dignidades administrativas o eclesiásticas.

Desde este punto de vista, los modelos de educación y de socialización de las sociedades del Antiguo Régimen no fueron muy distintos a los de las que le precedieron. No obstante, en medio de este panorama continuista, se apreciaban cambios que anunciaban las futuras sociedades modernas. A estos cambios nos referiremos en el capítulo siguiente. Antes de referirnos a ellos recapitulemos todo lo dicho acerca de las formas de educación en las sociedades preindustriales.

\section{Conclusión Parte I. La EduCación EN La SOCIEDAd PREINdUSTRIal. TRADICIÓN, CONVIVENCIA, TRANSMISIÓN}

A lo largo de la primera parte de esta obra hemos descrito las formas educativas características de las sociedades occidentales preindustriales, con una doble finalidad. Por una parte, la de contrastarlas con aquellas otras que gradualmente se irán imponiendo en las sociedades modernas. Por la otra, con el propósito de entender el proceso que ha conducido a nuestro modo de entender la educación, aquél que irá emergiendo poco a poco a lo largo de la época moderna, tal como veremos en la segunda parte de este libro.

¿Cuáles eran las señas de identidad de esta manera de concebir la educación que fue la propia de las sociedades tradicionales occidentales? Hemos querido responder a esta cuestión recorriendo tres de las grandes etapas que han marcado la historia de occidente, también desde el punto de vista educativo. 
La primera de estas etapas corresponde al mundo clásico, tantas veces señalado como la cuna de la cultura occidental, y como el origen de una determinada mentalidad educativa que estará presente, aunque atravesada por numerosos cambios, hasta la llegada de la sociedad industrial. Una mentalidad caracterizada por entender la educación en relación con un estilo de vida de carácter aristocrático que priorizaba los ideales guerreros, políticos y culturales, despreciando, por el contrario, todo lo relacionado con la vida laboral y productiva. Ideales que se expresaban por medio de la palabra y de la acción, consideradas las cualidades supremas de todo ser humano, y por ello superiores a labor, e incluso a la fabricación, mucho más deshumanizantes (Arendt, 1998).

Esta forma de entender la educación se vinculaba también, tanto para los griegos como para los romanos de la antigüedad, con una tradición que confería un especial sentido a su particular género de vida, y en la que se reconocían todos aquellos que querían ser respetados y reconocidos. Con independencia de que quienes encarnasen dicha tradición fuesen los héroes del pasado o los mitológicos, en el caso de los griegos, o los propios antepasados, venerados especialmente por los romanos, lo que importaba en ambos casos era prolongarla. No tanto para fundirse con ella, sino para recrearla a partir del legado recibido, mostrando a las nuevas generaciones por qué valía la pena perseguir ese ideal de vida, y ser así reconocido, respetado y recordado, incluso después de muerto.

Para educar a los más jóvenes en esta tradición, tanto griegos como romanos confiaron en el ejemplo proporcionado por sus mayores, quienes mejor la conocían; ejemplo que se interiorizaba observando y actuando entre ellos, adquiriendo así los hábitos más apropiados a ese estilo de vida.

Esta manaera de entender la educación tenía dos importantes implicaciones. Por un lado, la absoluta preeminencia de la edad adulta, considerada la edad perfecta en la jerarquía de las edades, y con respecto a la cual tanto la infancia como la juventud eran consideradas etapas incompletas e imperfectas. Por el otro, la escasa importancia de la formación escolar que, por su carácter técnico y utilitario, se entendía que apenas contribuía a educar en aquel género de vida superior de tipo aristocrático al que se consagraban todos los que estaban liberados de que tener que trabajar para vivir. Un género de vida que sólo se podía adquirir viviendo entre iguales.

El mundo medieval incorporó en buena medida la mentalidad educativa greco-romana, si bien interpretándola en conformidad con la cultura cristiana. Desde este punto de vista, siguió dando prioridad a aquel tipo de educación alejada del mundo productivo, cuya máxima expresión era el estilo de vida aristocrático-caballeresco orientado al oficio de las armas y a todo lo que ello representaba. En este contexto, la educación continuó teniendo un fin socio-moral antes que técnico o 
utilitario, pues el desempeño de los diferentes oficios, fuesen estos bajos o nobles, conllevaba la integración en un universo socio-cultural que otorgaba un particular significado a aquel desempeño (Durán, 2011).

La religión cristiana impregnaba en el medievo todos los órdenes de la vida, confiriéndoles un determinado sentido. A ella se remitía también la tradición a la que todos los estamentos sociales se vinculaban.

Los guardianes de dicha tradición eran las personas adultas que, tal como ocurría en el mundo greco-latino, representaban el modelo en el que tenían que mirarse todas las demás edades, concebidas por ello como imperfectas, por lo que sólo superaban dicha condición una vez alcanzaban el periodo adulto. Desde esta perspectiva, la mentalidad medieval, como antes lo hiciera la greco-romana, desconfió de la infancia, de la adolescencia y de la juventud, consideradas etapas impetuosas y todavía poco racionales. De todos modos, se entendía que esta irracionalidad se refrenaba con la edad, con la entrada progresiva en el mundo de los adultos. Por esta razón, la infancia en sus primeros años de vida levantaba una gran desconfianza, en virtud de su débil integración mundana. Aunque, paradójicamente, también por este motivo era objeto de veneración debido a su extrema pureza. Esta doble condición de la primera infancia, portadora a la vez del pecado original, y por tanto tendente a un ímpetu perverso, pero también de un alma pura aún no contaminada por el mundo, influirá en el pensamiento educativo posterior, cada vez más desprendido de este espíritu religioso. En efecto, cuando en un contexto ya plenamente secularizado, la naturaleza infantil se conciba como originalmente bondadosa, frente a un mundo que se cree que la perturba, se habrá roto definitivamente con la tradición anterior, inaugurándose un nuevo modo de entender la educación que ya es plenamente moderno.

Pero hasta ese momento será el mundo, hecho y considerado a la medida de los adultos, el que se situe en un primer plano, y a él tendrán que plegarse infantes y jóvenes. No obstante, esta sumisión no suponía una mera aceptación pasiva, pues implicaba ante todo la participación activa de la infancia y de la juventud en los escenarios de la vida adulta, observando y tomando ejemplo de todo lo que allí ocurría; un ejemplo ofrecido con hechos y con palabras.

Frente a este tipo de educación, apenas contaba la proporcionada por las instituciones escolares. Éstas fueron casi inexistentes en la alta Edad Media, y, aunque adquirieron después, al final de este periodo, una mayor importancia, siguieron manteniendo un carácter residual, reservándose casi exclusivamente para los futuros clérigos. Así tenía que ser en una cultura fundamentalmente oral, que confiaba más, como medio de socialización y de transmisión, en la convivencia social que en la enseñanza formal, sólo necesaria para aquellas pocas personas que tenían que saber leer, escribir y contar. Para lo cual bastaba con asistir un poco a la escue- 
la. Más allá de este hecho, sólo prolongaban su estancia escolar aquellos que iban a dedicarse más tarde a la clerecía.

La enseñanza escolar continuará teniendo una escasa relevancia para la mayoría de los grupos sociales en las sociedades del Antiguo Régimen, aunque ya no para las élites. En efecto, al abandonar éstas gradualmente su condición guerrera y caballeresca para convertirse en cortesanas en el contexto de los nuevos Estados Monárquicos, sentirán la necesidad de educarse para conformar su nueva identidad en aquellas prácticas y en aquellos saberes que, siguiendo el modelo humanista, se habían convertido en los signos principales de la buena educación y de la alta cultura. Emergerá así un modelo educativo en base al cual se distinguirán las personas cultas y civilizadas de aquellas otras consideradas vulgares.

Este programa educativo es el que los adultos proponían como modelo para educar y socializar a la infancia. Todo lo cual conllevaba una buena dosis de represión, que no excluía sin embargo la aceptación más o menos pasiva de las conductas desviadas de los que querían así señalar ritualmente su condición juvenil, como antes lo habían hecho sus mayores. Una condición percibida como una estación de paso por la que todas las edades habían de transitar antes de arribar a la última parada, la integración final en la vida adulta. Esta integración se producía gradualmente, a través de la participación de la infancia y de la juventud en los escenarios del mundo adulto, sin que hubiese la conciencia ni la voluntad de separar a las distintas edades, todas ellas orientadas a la misma meta.

No obstante, en medio de este universo social surgieron también otras mentalidades y otras prácticas que eran la expresión de una voluntad algo diferente. El germen de esta nueva forma de pensamiento se podía ya encontrar en el propio proyecto civilizatorio humanista. En efecto, si por un lado la mentalidad humanista tenía la firme intención de reprimir los impulsos más naturales en la infancia por medio de su integración en el mundo civilizado; por el otro consideraba que en aquella naturaleza anidaba una bondad y una inocencia llena de potencialidades. Ambas perspectivas desembocaron en la misma voluntad de mantener separada a la infancia de la edad adulta, con la intención de preservarla de la mala influencia de aquellas actitudes y comportamientos considerados poco civilizados.

A esta separación de las edades contribuirán también algunas de las instituciones escolares más destacadas de la Contrarreforma, y en especial los colegios de los Jesuitas. Primero, integrando a la infancia y a la juventud en un medio clausurado, apartado del resto del mundo. Después, por su tendencia a racionalizar la vida colegial, diferenciando al alumnado por edades y por cursos. Las instituciones escolares así configuradas no dejarán de crecer a lo largo del Antiguo Régimen, porque satisfacían las necesidades de la nueva nobleza, ávida de imbuirse de la cultura humanista, pero también de adquirir los conocimientos necesarios para 
emprender la carrera eclesiástica o la administrativa. Estas necesidades se harán sentir también en aquellos miembros de la naciente burguesía que aspiraban a mejorar su posición social ocupando los puestos de la administración del Estado.

No obstante, incluso estas personas continuaron durante mucho tiempo dando prioridad al tipo de educación que se adquiría a través del trato con las gentes, siguiendo su palabra y su ejemplo. Esa clase de educación fue la que realmente imperó en las sociedades preindustriales, y la que irá perdiendo fuerza a medida que el industrialismo haga notar sus efectos.

Será entonces cuando se imponga otro tipo de educación más utilitaria y práctica, relacionada directamente con lo que requería la naciente sociedad industrial. Un requerimiento completamente alejado de aquel otro de carácter aristocrático, que descansaba en la tradición, y cuyo contenido era abiertamente antiproductivo. Este nuevo programa educativo no precisaba ya tanto como el que le precedió señalar la jerarquía de las edades, poniendo a la adulta como modelo. Si bien es cierto que, en un primer momento, el del industrialismo paternalista y patriarcal, aún persistirá dicha jerarquía, ésta carecía del anterior contenido moral, presentándose como pura forma disciplinaria.

Tampoco precisará este nuevo modelo educativo industrial de los mismos medios para imponerse. Aquellos que en la etapa preindustrial suponían la transmisión entre las distintas generaciones por medio de la convivencia, la palabra y el ejemplo, y en el que la educación y la instrucción estaban estrechamente vinculadas. Los medios que el industrialismo pondrá en práctica serán, en efecto, otros, principalmente la escuela y la fábrica, en donde se proporcionarán los rudimentos de una formación técnica, inculcando además la disciplina que requería el nuevo productivismo (Pollard, 1987; Thompson, 1979).

Este cambio de paradigma educativo tenía, sin embargo, raíces mucho más profundas. Venía gestándose desde hacía ya varias centurias, desde los inicios de la época moderna, en torno al siglo XV, en ese otro perido mucho más dilatado en el que van cristalizando las mentalidades (Vovelle, 1985), siendo abanderado por una pequeña élite de intelectuales sensible a los signos de los nuevos tiempos. Sólo más tarde dicha mentalidad acabará impregnando gradualmente a los distintos grupos sociales; primero, a la burguesía, y después al grueso de las clases productivas, en el contexto de los profundos cambios sociales que acompañaron la llegada del industrialismo. En el próximo capítulo, con el que se inaugura la segunda parte de la presente obra, se describirá el origen y el desarrollo de este nuevo modo de entender la educación que ha conformado el pensamiento educativo moderno, del cual somos los claros herederos. 
PARTE II

GÉNESIS, TRANSFORMACIÓN Y CRÍTICA DEL PENSAMIENTO EDUCATIVO MODERNO 



\section{CAPÍTULO I \\ LA EDUCACIÓN DEL SUJETO MODERNO. GENEALOGÍA DE UN DISCURSO}

Si los niños fueran movidos por un poderoso impulso que les llevara a crear un nuevo cielo y una nueva tierra, los adultos podrían beneficiarse permaneciendo a un lado y dejando campo libre al experimento. Pero no hay tal virtud creadora en los niños. Estos sólo pueden construir con el material que les ofrece la tradición. Liberados a ellos mismos, desprovistos de toda tradición o enfrentados con valores que no pueden respetar, levantarán construcciones sin contenido alguno (Mead, 1962: 140).

\section{INTRODUCCIÓN}

El primer capítulo de la segunda parte de esta obra estará dedicado a reconstruir el proceso genealógico que ha conducido a la conformación de una manera de entender la educación cuyo legado hemos recibido. Tal como se verá a lo largo de este capítulo, esta nueva mentalidad fue impulsada en un primer momento por las diferentes élites intelectuales; posteriormente se difundió entre las élites políticas y sociales; y más tarde fue incorporada por los diferentes grupos sociales, conformando un cierto sentido común de las gentes (Taylor, 2006: 37-38).

Mucho después, a partir de finales de los años 60 del siglo pasado, este pensamiento, así configurado, fue sometido a crítica por una serie de autores vinculados a la sociología crítica y a la pedagogía libertaria. Esta crítica, que por un lado era abiertamente rupturista con la tradición anterior, pero que por otro no hacía más que reconfigurarla, fue muy bien recibida por amplios sectores sociales, conformando muchos de los lugares comunes de la mentalidad educativa actual.

El pensamiento educativo moderno se estructuró a partir de dos grandes ejes. Por una parte, el individual, articulado alrededor de la idea de un sujeto autónomo, portador de una naturaleza a la vez común y singular. Y por la otra el colectivo, que remitía este sujeto a un universo social que lo constreñía, pero que también posibilitaba su desarrollo en condiciones de igualdad con sus semejantes (Dubet, 2006; Gauchet, 2002). 
A lo largo de la modernidad se ha ido modificando la relación entre estos dos grandes ejes. En un principio, la dimensión social, basada en la tradición, tendrá un mayor peso. Pero poco a poco irá ganando importancia el individuo, hasta convertirse en el verdadero protagonista del proceso educativo. No obstante, en un principio, este protagonismo estuvo mitigado por el peso de las instituciones, y en particular de las educativas, a las que los sujetos no tenian más remedio que plegarse para lograr su ansiada autonomía.

Este encuentro fructífero entre el sujeto y la colectividad a través de la relación institucional, cuya máxima expresión fue la escuela republicana, se quebrará más tarde, a partir de finales de los años 60 del pasado siglo, por la influencia de una mentalidad que veía en aquél lazo institucional la manifestación de una opresión que sólo era posible superar volviendo a un sujeto sin determinaciones, en el contexto de una comunidad igualitaria y libre.

En los dos capítulos que constituyen la segunda parte de esta obra se mostrará las principales etapas que jalonaron el proceso anteriormente descrito. En el primer capítulo, se relatará la genealogía del pensamiento educativo moderno desde los autores humanistas hasta Émile Durkheim y John Dewey, que contribuyeron a la legtimación del programa educativo que imperó en las democracias industriales occidentales hasta los años 60 de la pasada centuria. En el segundo capítulo, se describirá la crítica realizada a este modelo por una serie de destecados e influyentes intelectuales pertenecientes al ámbito de la sociología crítica y de la pedagogía libertaria.

Tanto uno como otro tipo de pensamiento acabarán influyendo sustancialmente en una manera de pensar la educación que, como se verá, es en buena medida la nuestra.

\subsection{EL CONTEXTO DE LA NUEVA IDEOLOGÍA}

El discurso educativo moderno emergió en los albores de la Época Moderna en medio de un determinado contexto social e ideológico. En este contexto intervinieron una serie de fenómenos. Entre ellos cabe destacar la Reforma Protestante y la Contrarreforma, la Ciencia Moderna y la filosofía cartesiana, el Estado Monárquico y su posterior transformación en Estado-Nación, y la industrialización. Todos estos procesos contribuyeron a forjar un nuevo modo de entender la educación que será el propio de la modernidad. Veamos brevemente de qué forma lo hicieron.

El Estado Moderno favoreció la aparición de una nobleza cortesana, cuyos comportamientos y cuyas actitudes pasarán a ser identificadas como las propias 
del sujeto civilizado (Elías, 1993: 115 y ss). La civilidad, así entendida, servirá como modelo para inculcar buenas maneras y conocimientos, y como tal se integrará, como hemos mostrado en la primera parte de esta obra, en el programa educativo Humanista, y también en el de las órdenes religiosas de la Contrarreforma. Surgirá así una nueva concepción de la educación, de vocación humanista y universalista, que estará en el origen de la pedagogía moderna, cuya finalidad principal será civilizar a la infancia, fundamentalmente a la de la nobleza y la burguesía (Taylor, 2006: 56 y ss; Varela, 1991: 66-67).

El protestantismo, no compartirá estos postulados. Creará, como se sabe, uno nuevo ethos profesional que valoraba el trabajo como medio principal de santificación (Weber, 1998: 162 y ss). Desde esta óptica la educación ya no tendrá como principal finalidad hacer que el niño penetre en la densidad del mundo que le precede, un mundo esencialmente cristiano, aristocrático e improductivo, como querían los humanistas. La escolarización de la infancia se justificará más por razones materiales- procurar el sustento a todo el pueblo-, políticas- asegurar el buen gobierno-, y por supuesto también religiosas- enseñar la palabra de Dios a todos los fieles (Sommerville, 1982: 88 y ss; Lutero, 1961a y b).

He aquí dos modos diferentes de entender la educación que estarán presentes a lo largo de la modernidad, y que sin embargo, a pesar de sus discrepancias, compartirán ciertas ideas comunes. En efecto, tanto para protestantes como para humanistas la educación era una empresa universal que, si se servía del método más adecuado, sería capaz de infundir los principales conocimientos a unas naturalezas humanas cuyas posibilidades eran casi infinitas (Garín, 1987: 186). La infancia aparecía por primera vez desde esta perspectiva como la verdadera protagonista de la acción educativa (Ramirez-Boli, 2001: 306). No obstante, para los humanistas este protagonismo estaba mucho más atenuado por la influencia de una tradición en el que necesariamente esta edad había de introducirse, mientras que para los protestantes esa misma tradición no dejaba de ser fuente de sospechas.

La filosofía cartesiana y la Ciencia Moderna influyeron también decisivamente en la conformación de esta nueva mentalidad educativa. El cartesianismo, al situar el yo racional del hombre en el primer plano de la realidad, un yo solipsista distanciado del mundo, transformó la visión que hasta entonces se había tenido del conocimiento. En efecto, al considerar la conciencia racional e introspectiva del ser humano como fundamento último de todo lo existente, "el juego de la mente humana consigo mismo" (Arendt, 1998: 310), Descartes priorizó el conocimiento lógico-deductivo, y en particular, el matemático. Como esta conciencia era, además, común a todos los hombres, todos tendrían que ser conducidos según el mismo método. Y como la expresión externa de esa racionalidad era la experimentación, la acción práctica del ser humano, lo que éste hace pasará a ser considerado 
como la prueba irrefutable del conocimiento (Arendt, 1998: 306 y ss). Se aprende, en efecto, haciendo.

Todas estas concepciones influyeron decisivamente en la pedagogía moderna. De hecho, quien habitualmente se presenta como uno de sus primeros fundadores, Comenius, no dejará de reconocer abiertamente su deuda con Descartes (Comenius, 1976: Prólogo).

Esta pedagogía se verá influida además por el nuevo espíritu que instauró la Ciencia Moderna. Los defensores de este espíritu se empeñarán, sobre todo a partir del siglo XVII, en mostrar que la esencia del conocimiento, de todo lo que hay que saber y que conocer, está en las cosas de la naturaleza, y que el método más adecuado para escrutarlas y comprenderlas era el científico. Todo ello con la finalidad, eminentemente práctica y utilitaria, de proporcionar la mayor riqueza y el mayor bienestar al ser humano sobre la tierra. "El verdadero fin y la función de la ciencia" no está- escribe Bacon- "en discursos plausibles, divertidos, memorables o llenos de efecto, o en supuestos argumentos evidentes, sino en el obrar y trabajar, y en el descubrimiento de datos hasta ahora desconocidos para un mejor equipamiento y ayuda en la vida" (Citado en Horkheimer y Adorno, 1999: 51). De acuerdo con esta actitud, se aconsejará el abandono de los saberes más humanistas, calificados por los defensores del nuevo espíritu científico de pedantescos, y su sustitución por otros más provechosos para la humanidad. "Medítese- afirma Bacon- en los verdaderos fines del conocimiento y búsquense, no por el placer mental, o para la contienda o por ser superiores a otros... sino para beneficio y uso de la vida" (Bacon, 1975: 14). En lugar de las palabras, "que hacen violencia al espíritu y lo turban todo" (Bacon, 1975: 42), las cosas (Garin, 1987: 203; Foucault, 2009: 26 y ss). Las cosas de la naturaleza y de las artes mecánicas, que son las que mayor utilidad tienen. "Vosotros- proclaman los habitantes de la "Ciudad del Sol" de Campanella- consideráis más sabio al que sabe más Gramática o Lógica (...), de ese modo no se dedica a conocer las cosas, sino solamente las palabras de los libros. Y por tal manera envilece su alma con signos muertos" (Camapanella, 1985: 156).

La educación ha de estar, pues, encaminada al aprendizaje de los distintos oficios, de las matemáticas y de las ciencias (Campanella, 1985. 154-55). Y guiada siempre por el mejor método, un método racional basado en la observación y en la experimentación (Bacon, 1975: 53), respetando además las inclinaciones naturales de cada sujeto (Campanella, 1985: 174).

Este nuevo espíritu educativo no recibió, sin embargo, su verdadero impulso hasta que el proceso de industrialización y de consolidación de los Estados Nacionales no estuvo lo suficientemente avanzado. Aunque ya con anterioridad las élites ilustradas integradas en los Estados Monárquicos del Antiguo Régimen lo habían promovido. Estados que, como afirmara uno de los más destacados Mercantilista 
del siglo XVIII, tenían "necesidad de hombres- de hombres trabajadores y aplicados-, pero nunca de sabiondos ni de pedantes" (Genovesi, 1785 I: 95). No obstante, serán los Estados Nacionales los que más claramente verán en la educación uno de los más eficaces instrumentos para dotar a la nación de los trabajadores que requería la naciente industria. El código civil Prusiano de 1794, el primer país que formalizó en 1810 un sistema de enseñanza público, así los establecía, al considerar que "las escuelas y las universidades son instituciones del Estado que tiene por fin la instrucción de la juventud en los conocimientos útiles y científicos" (Luzuriaga, 1994: 154).

Sin embargo, la importancia que los Estados Nacionales otorgaron a la educación no se agotaba en estos objetivos. Querían también formar ciudadanos imbuidos con la debida conciencia nacional. "Cuando seáis hombres- decía el método educativo del francés peigné- ocupareis un lugar en la sociedad. Vuestro primer deber será entonces amar a la patria y obedecer las leyes" (citado en Prost, 1970: 128). Si bien este deber patriótico tendrá un carácter más autoritario o más liberal en función de la condición de cada Estado. La educación se convirtió así en uno de los principales instrumentos del progreso individual y colectivo. En el medio principal para crear buenos ciudadanos y honrados trabajadores.

A lo largo del siglo XIX irán surgiendo gradualmente los distintos sistemas educativos nacionales con voluntad universalista (Bowen, 1985 III: 335 y ss; Luzuriaga, 1994: 181 y ss; Prost, 1970). No será, sin embargo, hasta después de la Segunda Guerra Mundial cuando los Estados Occidentales lleven esta voluntad a la práctica (Manacorda, 1987 II: 526; Prats-Reventós, 2005: 230), de acuerdo con un ideario que concebía laa educación como uno de los más importantes medios para impulsar el desarrollo económico, reducir las desigualdades sociales y crear una sociedad más libre y democrática.

Desde comienzos de los años 70, cuando el consenso de posguerra se estaba agotando, en un contexto menos armónico desde el punto de vista económico, social, político e ideológico, comenzaron a surgir una serie de críticas que cuestionaban que la educación hubiese cumplido realmente con el programa que la modernidad le había asignado.

Muchas de estas críticas incidieron más en el carácter represivo que en la intención liberadora e igualitaria de las instituciones educativas. Esta intención no era más, según estos críticos, que un medio de legitimar las desigualdades y las jerarquías latentes.

En este escenario la fuerza del proyecto educativo moderno fue cediendo ante el avance de nuevas propuestas que reclamaban un mayor protagonismo de los sujetos. No obstante, estas propuestas, a pesar del carácter rupturista con el que 
se enunciaban, contenían varios de los principios que habían nutrido el discurso educativo moderno. Un discurso cuya genealogía reconstruiremos en las páginas que siguen.

\subsection{LA EDUCACIÓN DEL SUJETO MODERNO}

El presente epígrafe estará dedicado a mostrar el proceso por el que se originaron y se configuraron históricamente aquel conjunto de ideas que a lo largo de la modernidad han dado lugar a una determinada manera de pensar la educación, que primero orientó la mentalidad de las élites y más tarde la del común de las gentes. Estas ideas son las que han integrado la conciencia educativa propia de la modernidad. A describir cómo se forjó esta conciencia estarán consagradas las páginas siguientes.

\subsubsection{La civilidad humanista}

El humanismo fue un movimiento intelectual e ideológico que se desarrolló en el contexto de la contrarreforma y de los emergentes Estados Monárquicos. En este contexto, su ideal era proporcionar el tipo de educación que precisaba la naciente nobleza cortesana, cuya fuerza ya no estaba en las armas, sino en los comportamientos, en las actitudes y en las palabras.

Puede ya percibirse en esta nueva concepción de la educación la creencia moderna en la perfectibilidad humana; en la capacidad racional del ser humano que, debidamente conducido por el educador, se considera que podrá alcanzar casi cualquier meta (Durkheim, 1992: 227 y ss; Garin, 1987: 78 y 145). "Yo pienso- escribe Erasmo- que apenas existe disciplina para la cual el hombre no nazca más o menos dócil, si se insiste en sus preceptos y en su práctica" (Erasmo, 1964: 936-938). Práctica que debe comenzar desde la más tierna infancia, pues es en este momento cuando la naturaleza es blanda y flexible, por lo que se puede imprimir en ella todo lo que se desee. Todo ello sin brusquedades ni violencias, de una forma cercana y suave:

Hase de engañar- afirma Erasmo- con determinados atractivos aquella edad que todavía no puede conocer cuánto fruto, cuánta dignidad, cuánto placer han de proporcionarle las letras en un porvenir cercano. Conseguirán en parte este resultado- nos dice- la suavidad y el comedimiento del preceptor, y en parte, el ingenio y la habilidad con que ameniza sus enseñanzas con varias invenciones que harán al niño las lecciones agradables y le harán olvidar la violencia del esfuerzo (citado en Varela, 1984: 36). 
La pedagogía Humanista, desplegada ampliamente por las instituciones educativas de la Contrarreforma para sus propios fines religiosos, integrando piedad y buenas letras (Varela, 1991: 58; Durkheim, 1992: 293; Garin, 1987: 188), dio lugar así a una nueva preocupación por el desarrollo de la infancia, a la que se consideraba dotada de una particular naturaleza, maleable y flexible, apta para su posterior desarrollo en la dirección que el educador se propusiese (Zweig, 2005: 95).

Y sin en mi infancia- escribe Della Casa en su Galateo-, cuando los ánimos son tiernos y moldeables, aquellos que se preocupaban por mi hubieran sabido doblegar mis costumbres, quizás algo duras y toscas por naturaleza, y ablandarlas y pulirlas, yo habría salido por ventura como ahora procuro hacerte a ti (Della Casa, 2003: 208).

Ahora bien, dicha naturaleza tenía que introducirse en una realidad que la transcendiese y la configurase, sin perturbar por ello sus potencialidades. "El hombre- escribe Erasmo- no nace formado, es el fruto de un trabajo de formación" (citado en Garin, 1998: 251). Una formación que tenía que estar vinculada a la civilidad humanista, por medio de la cual la humanidad, se pensaba desde esta perspectiva, alcanzaría la más alta perfección jamás antes lograda (Zweig, 2005: 16).

Este programa civilizatorio respondía a lo que demandaba, para conformar su nueva identidad, la nobleza cortesana, cuya principal fuente de inspiración estaba, tal como se ha mostrado, en las obras de los principales humanistas (Elias, 1993a: 211). Para apropiarse de dicha educación ya no era suficiente con disponer de lo que a cada uno la naturaleza le hubiese dado. Ya que, tal como escribe Erasmo, "la naturaleza ha menester de la razón, y el ejercicio, si la razón no lo gobierna, anda expuesto a muchos peligros y errores" (1964: 931-932). La naturaleza es, pues, condición necesaria pero no suficiente. Tendrá que ser moldeada y perfeccionada por medio de los usos y de las costumbres que conforman la razón humana, usos y costumbres que, para ser interiorizados, precisan de una práctica repetida en contacto con los seres humanos. "No es cierto, pues, que frente a la naturaleza no existe freno ni maestro, - se dice en el Galateo-, "hay dos" -se responde-, "ya que uno es la costumbre y el otro la razón". Ahora bien- se añade-, esta última "no puede hacer de un hombre maleducado uno educado sin la costumbre, que es casi parto y fruto del tiempo" (Della Casa, 2003: 210). Algo parecido podemos leer en el Cortesano: "Por eso se ve claramente- se afirma- que el uso tiene mayor fuerza que la razón para introducir en nosotros cosas nuevas y destruir las viejas" (Castiglione, 1994: 102).

Desde esta perspectiva, no se considera, pues, que haya que liberar a la naturaleza humana de una hipotética realidad social que la constriñe, sino que dicha liberación tendrá lugar, precisamente, por su inmersión en ella (Erasmo, 1964: 932). Pervive aquí, por tanto, aquella concepción dual de la primera infancia que había 
impregnado la mentalidad educativa a lo largo de toda la Edad Media. En efecto, así como hay una naturaleza humana buena, aun no contaminada por los males del mundo, así también, se entiende, de acuerdo con la tradición clásica, interpretada según la doctrina cristiana, que en dicha naturaleza hay algo perverso, procedente del pecado original, que es necesario refrenar. "Averiguaron esto con gran extrañeza suya los filósofos paganos- escribe Erasmo- y no atinaron a explicarse la razón que a nosotros nos descubrió la filosofía cristiana, que enseña que esa nuestra proclividad al mal nos provino de Adán, nuestro primer padre" (Erasmo, 1964: 940).

Habrá, pues, que reprimir en la infancia, de la forma más racional y suave posible, todos estos malos impulsos provenientes de la naturaleza, y potenciar, por el contrario, mediante la educación humanista y cortesana, basada en la piedad, la urbanidad y las buenas letras, las actitudes y los comportamientos más adecuados.

Para ello, será preciso primero proteger a la infancia de toda mala influencia, porque, aunque su naturaleza sea potencialmente racional y flexible, es todavía débil. Y porque además hay que depurar y reprimir en ella todo cuanto no sea civilizado. Para después introducirla gradualmente en el mundo, con la intención de enderezarla, civilizándola.

Para lo primero, para proteger a la infancia de lo malo que hay en el mundo, será necesario en un principio separarla, lo que se traducirá en una creciente distancia entre esta edad y la adulta (Elías, 1993: 208). Lo que a su vez favorecerá el desarrollo de una pedagogía centrada en la infancia, provista de todo un programa moral y educativo (Varela, 1991: 32-33). No obstante, por el momento, esta distancia todavía no existía. "Se atempera este mal" -el mal comportamiento, nos dice Erasmo- "si el niño se acostumbra a vivir entre los mayores" (1985: 27). La meta de la vida era todavía, en efecto, la edad adulta, y entre adultos ha de vivir quien acabará algún día siéndolo (Garin, 1998: 289). Observando y tomando de ellos su ejemplo, es como debe ser educada, pues, la infancia, adquiriendo las formas y las actitudes corteses, y también los saberes clásicos, todos ellos aprendidos con respeto y obediencia.

Este tipo de educación, primero considerada cortés y más tarde civilizada (Elias, 1993), separará a la nobleza cortesana del resto de los grupos sociales, cuyas formas, actitudes y saberes serán considerados vulgares. "En guisos caldosos sumergir los dedos es de pueblerinos", afirma Erasmo en sus consejos de urbanidad para los niños (1985: 53). De pueblerinos, y por tanto de gente ordinaria, porque carecen del refinamiento que distingue a las personas del vulgo de las cultivadas.

Se da aquí, pues, una doble tendencia. Por un lado, el programa educativo humanista anticipa la modernidad, por su inclinación a centrarse en la naturaleza del sujeto infantil, que se considera dócil y maleable, queriéndola guiar de acuerdo con 
sus intereses y sus potencialidades, suave y tiernamente. "Para educar- escribió el humanista italiano Leon Battista Alberti- es necesario darse cuenta de las aptitudes, de la propia naturaleza de cada niño: es necesario encontrar el camino para seguir y guiar su naturaleza" (Garin, 1987: 132-133). Por el otro, sin embargo, dicho programa trata de reprimir esta misma naturaleza, inculcándole normas y saberes apropiados a la tradición que le sirve como modelo, la humanista-cortesana. Esta doble intención, la de centrarse en el sujeto para transformarlo, y la de socializarlo, sometiéndolo a normas externas que despierten en él una determinada conciencia, pervivirá a lo largo de la Época Moderna. No obstante, por el momento el peso del programa socializador era tan fuerte, que la preocupación por el individuo sólo encontraba sentido en su seno. En el seno de una sociedad nobiliaria y aristocrática, en la que el saber no tenía otra utilidad que no fuese la de despertar en los sujetos el gusto y el aprecio por las cosas del mundo culto y civilizado (Garin, 1987: 191).

Por todas estas razones, dentro de este programa educativo no había apenas distinción entre instrucción y educación. En efecto, las personas instruidas en las artes liberales eran también las más educadas y las más civilizadas. Así lo ponía de manifiesto Rabelais en su famosa obra Gargantúa y Pantagruel (1530). "Por esto, hijo mío, te exhorto- dice Pantagruel a su hijo Gargantúa- a que emplees tu juventud en progresar mucho en las virtudes y en los estudios. Estás en París y tienes a tu preceptor y a Epistemón; el uno con vivas y agradables instrucciones, y el otro, con loables ejemplos, te pueden enseñar" (Rabelais, 1971: 247).

Esta finalidad del saber adquirirá otro tono en los pedagogos de la Reforma, sin que por ello desaparezca una confianza, todavía mayor, en las potencialidades de la naturaleza infantil y en el método racional-experimental, como principales medios para transformar aquella naturaleza, orientándola en la dirección que el educador se propusiese.

\subsubsection{La pedagogía de la Reforma}

El elitismo aristocrático, que había degenerado en un cierto formalismo retórico en el ámbito de las instituciones de la Contrarreforma, estará en buena medida ausente en la pedagogía de la Reforma, mucho más atenta a la educación popular y utilitaria de lo que lo había estado la Humanista. Esta última se había centrado, en efecto, en la enseñanza de las nobles artes y de las bellas letras, vinculadas al universo de una civilidad cristiana, cortesana y aristocrática, que se oponía por completo a aquel otro mundo utilitario de los distintos oficios, considerado propio de la gente burda y de baja condición.

Los representantes de la Reforma mantendrán sin embargo otra actitud, ejemplificada ya en la voluntad de Lutero de solicitar a las autoridades que exhortasen 
a los padres para que enviasen a sus hijos a la escuela. No por el afán- dice- "de cultivar la ciencia por la ciencia, sino para hacer de la instrucción un instrumento al servicio del Estado y de la Iglesia". Pues "es necesario- prosigue- que los hijos de la gente común gobiernen el mundo, tanto en el estado espiritual como en el temporal" (Lutero, 1961a: Introducción y 1961b: 187).

Posteriormente, en el siglo XVII, los pedagogos de la Reforma, y en particular Comenius (1592-1670), el más insigne de todos ellos, imbuidos de esta actitud favorable a los aspectos más útiles de la vida humana, pero también de un profundo espíritu racional y científico (Garin, 1987: 203), reaccionarán fuertemente contra la "inutilidad" de unos saberes a los que calificarán de elitistas, cargados de estilismo y de ornamentación, de retórica escolástica, de pedantería, para inclinarse por otros, accesibles a súbditos y señores, "que tienen una aplicación segurísima para esta vida y la futura" (Comenius, 1976: 83). "Educar rectamente a la juventud- escribe Comenius- no es imbuirle un fárrago de palabras, frases, sentencias y opiniones tomadas de los autores, sino abrir el entendimiento de las cosas" (1976: 85).

No puede haber pensamiento más contrario al espíritu humanista. Un espíritu convencido de que lo que se ve, lo que se dice, o se escribe; el lenguaje, en definitiva, es apto para descubrir las realidades del mundo (Huizinga, 1987II: 210). Desde esta perspectiva, lo que el ser humano está ávido por conocer no es el mundo como realidad material objetiva, que alberga secretos y utilidades para su propio bienestar, sino aquel otro del que los hombres hablaron y escribieron; ese mundo que sólo es posible conocer, comprender e interpretar a través del diálogo con los textos que los autores más ilustres, tanto los más recientes como los clásicos de la antigüedad, nos legaron (Durkheim, 1992: 348).

Muy diferente es la opinión de los pensadores protestantes, para los que las palabras ya no revelan el mundo; ese mundo que los Humanistas admiraban y que ponían como modelo de comportamiento. Ahora se piensa, por el contrario, que ocultan la realidad, impidiendo ver cuál es su esencia. Una esencia que se quiere buscar con la única ayuda de la razón y de los sentidos (Foucault, 2009: 62). Del encuentro entre una psique humana, que se percibe como racional y universal, y capaz de desentrañar todas las verdades que las cosas esconden, y esas mismas cosas de la naturaleza, brotará, pues, el conocimiento. Educar consistirá entonces en situar a la infancia en la "escuela de las cosas". Que en la escuela común se ejerciten- aconseja Comenius- "los sentidos y el entendimiento por medio de las cosas sensibles" (1976: 175). Porque la naturaleza humana, "sabia, honesta y santa" puede "conocer, nombrar y entender cuanto encierra el mundo entero" (Comenius, 1976: 18-8).

Esta confianza en las potencialidades de la naturaleza humana estaba ya presente en el Humanismo, pero los pedagogos protestantes, influidos por el 
cartesianismo, ${ }^{26}$ la llevaron casi hasta el infinito. "Tan inmensa es- creía Comenius- la capacidad de la mente humana que puede compararse a un insondable abismo" (1976: 12).

Como esta mente inconmensurable se creía, además, que era flexible y maleable, todos los seres humanos podrían ser educados desde la más tierna infancia "a donde su naturaleza les inclina" (...) "con un solo y mismo método". Aunque con el debido respeto a la "índole de la edad pueril" (Comenius, 1976: 44-81, 169). Como la naturaleza tiende, asimismo, hacia lo que tiene "un uso claro e inmediato" (Comenius, 1976: 80), nada podrá ser enseñado sino es para este fin. "Sin castigos ni rigor, leve y suavemente". Y, "si acontece lo contrario- escribe Comenius- no es por culpa de los que aprenden, sino de los que enseñan" (1976: 41-154).

Dedúcese de aquí que ya no habrá obstáculos, si se tiene la firme voluntad y el convencimiento, para educar a la infancia en todo aquello que se estime oportuno y necesario, esto es, en las cosas que al ser humano le resulten útiles para su vida en la tierra. " $¿ N o$ ha de poder el maestro de escuela- afirma Comenius con la confianza más rotunda- enseñar todas las cosas si tiene redactado como en un cartel todo lo que debe enseñar y los procedimientos para ello?” (1976: 183).

"Que en toda reunión bien ordenada de hombres (bien sea ciudad, pueblo o lugar)- pide Comenius a todas las autoridades, como antes lo hiciera Lutero- se abra una escuela como educatorio común de la juventud", para que allí "se la instruya entre los seis y los doce años (o trece) en todo aquello cuya utilidad abarca la vida entera". Se podrá así progresar en el "mejoramiento de los asuntos humanos, conforme a aquello de: la multitud de sabios es la salud del orbe de las tierras" (Comenius, 1976: 28-168; 187, comillas del original). Comenius se propone así educar a la humanidad entera, "que todos aprendan todas las cosas", dice (1976: 85). Y las más útiles serán sin duda aquellas que sirven para el desempeño de los distintos oficios, y por su puesto también para propósitos religiosos.

Si todo lo que dejamos indicado- afirma- tuviese exacto cumplimiento en esta escuela común, no encontrarían los discípulos al pasar a la escuela latina o al dedicarse a la Agricultura, Comercio, oficios, etc., nada que fuese para ellos tan nuevo que no hubiesen tocado en esta escuela, y, por lo tanto, todo cuanto ha de tratar cada uno en su oficio, lo que puede oir en las predicaciones sagradas (...) no será más que la ampliación de las cosas conocidas de antemano o la aplicación particular de alguna de ellas (Comenius, 1976: 169).

Como la finalidad de la enseñanza es, tal como se ha visto, basicamente utilitaria, la instrucción ha de estar basada más en el hacer que en el escuchar o memo-

De hecho, Comenius se entrevistó alguna vez con Descartes, reconociendo que la conversación con el filósofo lo había reafirmado en sus opiniones (Comenius, 1976: Prólogo XX). 
rizar. En efecto, "lo que ha de hacerse, debe aprenderse haciéndolo" (Comenius, 1976: 117). Comenius anticipa así a algunos de los más insignes representantes de la pedagogía moderna.

Ahora bien, la escuela así concebida, como un lugar abierto a todas las naturalezas, independientemente de su condición social (Vincent, 1980: 19), requiere una cierta disciplina. No obstante, esa disciplina no esta destinada a lograr una efectiva integración mundana. Comenius no se propone imponer normas de "externa urbanidad", como querían los Humanistas, sino a reprimir la "disposición interna y externa de nuestras pasiones" (Citado en Capitán Díaz, 1984 I: 486-487). Su método disciplinario está, pues, más encaminado a lograr el dominio espiritual del yo, el autocontrol, en consonancia con un espíritu protestante mucho más individualista, que a poner al sujeto en relación con el mundo. "Cristo aparta del mundo", nos dice; "ellos (en referencia a los autores clásicos que sirven de ejemplo a los Humanistas) sumergen más en él” (Comenius, 1976: 150).

La pedagogía reformista estableció así una serie de principios que contribuirán a conformar el pensamiento educativo moderno. Es moderno, en efecto, su interés por educar a toda la juventud con un sólo y mismo método. Lo es también una concepción del saber de carácter más utilitario y práctico, tanto por su finalidad, como por la forma en la que éste ha de ser transmitido, a través de la acción práctica de quien aprende (Sommerville, 1982: 117). Como moderno es también considerar que la igualdad entre los seres humanos es de orden natural y racional antes que mundana. Y lo es, asimismo, afirmar que, a pesar de esta igualdad, la infancia, potencialmente igual a la edad adulta, habrá de ser tratada con arreglo a su particular naturaleza. Una naturaleza que se manifiesta en múltiples tendencias que el educador ha de saber captar y orientar, para lograr así su mayor progreso y el de la sociedad en su conjunto. La educación se convertirá de este modo en una empresa orientada hacia el futuro.

No obstante, en la medida en que este pensamiento se articulaba en un marco religioso, aunque fuese tan individualista como el protestante, mantenía todavía una cierta relación con el mundo. “...a todos nos competen del mismo modo- escribe Comenius- la erudición, las costumbres y la piedad” (1976: 34).

Aunque la pedagogía reformista, al igual que la humanista, están en la base del pensamiento educativo moderno, durante mucho tiempo todavía coexistirá una concepción de la educación de carácter más aristocrático y elitista, como la de la Contrarreforma (Varela, 1991: 39), con otra más individualista, utilitaria y científica, como la de la Reforma. Ésta última ejercerá una notable influencia en el deseo temprano de algunas órdenes religiosas de fundar escuelas de artes y oficios, en las que se seguirá un método mucho más racionalista (Garin, 1987: 224). 
Esta doble tendencia, la una más aristocrática; la otra más racionalista, individualista y empirista, se aúnan en el pensamiento educativo de John Locke.

\subsubsection{El pensamiento educativo de John Locke. Entre tradición y modernidad}

El pensamiento educativo de John Locke (1632-1704) alcanzó una gran influencia en su época. Su obra más importante en este ámbito, publicada en 1693 (Locke, 1982), adquirió una gran popularidad ${ }^{27}$. Popularidad que probablemente se debiese a que las ideas que en ella se exponían comulgaban con la sensibilidad de la época (Stone, 1990: 256; Sommerville, 1982: 121). Una sensibilidad que comenzaba a despertarse en el seno de la burguesía entre finales del siglo XVI y comienzos del XVII, para difundirse más tarde también en el ámbito de la élite aristocrática, cada vez más emparentada con la burguesía a través de sus estrategias matrimoniales (Stone, 1990: 175). La obra de Locke ejercerá asimismo una notable influencia en las teorías pedagógicas del siglo XVIII (Garin, 1987: 229).

Hay en el pensamiento educativo de Locke un punto de vista claramente estamental, en correspondencia con un medio social que todavía se miraba en el espejo de la cortesía y de la civilidad. Su obra es deudora en este sentido de la corriente humanista inglesa. "Lo que más me importa- dijo- es formar perfectos gentilhombres" (citado en Garin, 1987: 229). A ellos irá dirigido, pues, principalmente su programa educativo.

Convive sin embargo con esta mentalidad, otra marcadamente racionalista y empirista, que conecta claramente con la ideología educativa moderna. Desde el primer punto de vista, la intención es educar al caballero, proporcionándole "hábitos y buenas costumbres" (Locke, 1982: 281). Desde el segundo, se pone más atención en el sujeto infantil, para que "siga solamente lo que su razón le dicta" (Locke, 1982: 54-55).

Si se atiende al primer punto de vista, aristocrático y humanista, la meta de la educación es el mundo; ese mundo cortés en el que la infancia ha de introducirse gradualmente por medio del ejemplo y del trato social con sus mayores. "Sería, ciertamente, una gran ventaja para los niños- escribe Locke a este respecto-, que hubiese cerca de ellos, desde muy temprano y desde que sean capaces de andar, alguien que tuviese habilidad para enseñarles buenas maneras". Esas maneras que distinguen a la gente educada del "hombre rústico" (Locke, 1982: 105 y 266). Ese alguien ha de ser necesariamente un adulto, y más concretamente un preceptor, quien mostrará a la infancia y a la juventud los peligros y las virtudes del mundo:

Esta popularidad no se limitó sólo a Inglaterra, el libro tuvo también una importante difusión en Holanda, Alemania, Suecia y España (Sommerville, 1982: 121). 
Es preciso- escribe Locke- que un joven antes de dejar el abrigo de la casa paterna, antes de que se sustraiga a la tutela de su preceptor, haya adquirido una cierta firmeza de carácter y haya sido puesto en relación con los hombres para seguir sus virtudes y no dejarle emprender un camino ruinoso, o arriesgarse en un precipicio fatal antes de estar familiarizado con los peligros del trato social y poseer la firmeza necesaria para no ceder a las tentaciones (...) El trato con los hombres le corrige de este defecto en gran parte, y, si no los corrige rápidamente, razón poderosa para tener un buen preceptor en casa (Locke, 1982: 113-114).

Desde este punto de vista, Locke concede mucha más importancia a este tipo de educación que a aquella otra que procura la escuela.

Todo el que pueda costear un preceptor y educar a su hijo en casa- afirma convencido-, le asegurará mejor que toda escuela maneras gentiles, pensamientos viriles, el sentimiento de lo que es digno y conveniente (...), y también que hará madurar más pronto al hombre en el niño (...) Frente a estos ejemplos así ofrecidos y observados mediante el trato con las personas adultas, las reglas que a los niños se les propongan, o las instrucciones que se les den por otros medios, harán mucho menos mella en ellos (...) Este es un arte que no se puede aprender ni enseñar en los libros. Nada puede proporcionarlo sino las buenas compañías y la observación juntamente (Locke, 1982: 115-116 y 157).

Locke pone, por tanto, desde esta perspectiva, al mundo cortés y civilizado, y al adulto que lo representa, por delante del de la infancia, como modelo y medio de toda enseñanza. "No hago esta observación- escribe- sino para haceros ver cuál es la importancia que en todas las partes de su vida tiene para vuestro hijo la sociedad que frecuente (...) La sociedad actúa sobre él con más fuerza que vosotros" (Locke, 1982: 277-278).

$\mathrm{Y}$, sin embargo, convive con este pensamiento otro que otorga un mayor protagonismo a la infancia, que, retirada de toda influencia mundana perversa, tendrá que ser educada a través de métodos racionales, suaves y lúdicos, conforme a sus naturales inclinaciones y motivaciones. "Todo el que tiene niños a su cargo- escribe Locke desde este punto de vista- debe estudiar con cuidado su naturaleza y sus aptitudes; reconocer por frecuentes experiencias el giro natural de su espíritu; observar, en fin, su fondo natural, cómo pueden desenvolverse y que son capaces de hacer" (Locke, 1982: 97). Y en todo esto hay que reparar, sostiene, porque el interés de la infancia es propio y particular, y no debe obedecer al criterio de los demás. "Los niños no establecen gran diferencia entre las cosas con tal que sean apropiadas a su edad- afirma-. Cuando prefieren una ocupación a otra, es que se rigen por la opinión de los demás" (Locke, 1982: 243).

Descubierto ese interés natural primigenio, es preciso enseñar a la infancia de la forma más amable y divertida posible, en consonancia con las características 
particulares de cada naturaleza y de cada espíritu. Ha de presentarse la enseñanza, pues, "como un recreo y no como una tarea". Huyendo siempre de mostrarla como algo "que se asemeje a un trabajo o a una cosa seria, pues ni su espíritu ni su cuerpo sabrían acomodarse a ello" (Locke, 1982: 242-243 y 283). Y como la mente infantil es, además, una especie de papel en blanco en el que todo puede imprimirse con el debido método, "todo temperamento natural debe ser llevado tan lejos como sea posible" (Locke, 1982: 98).

Desde esta perspectiva, por tanto, la educación está más focalizada en el aprendizaje que en la enseñanza. Mientras que desde aquella otra que tiene al mundo adulto como modelo, esta relación prácticamente se invierte, para inclinarse más del lado de aquellos que tienen la responsabilidad y la facultad de transmitir el conocimiento.

El pensamiento de Locke se sitúa así entre la tradición y la modernidad. Desde la primera perspectiva, su intención es integrar a la juventud y a la infancia en un mundo que le precede; ese mundo cortesano-estamental que tendrá que asimilar a través del trato con sus mayores, observando y siguiendo su ejemplo. "Será inútil que discurráis con vuestro hijo sobre las obligaciones de la urbanidad- aconseja en este sentido-, sus maneras dependerán de la compañía que frecuente" (Locke, 1982: 272). Desde la perspectiva más moderna, su interés está, sin embargo, en la infancia, cuya naturaleza racional, sin prejuicios y llena de potencialidades, tendrá que ser educada conforme a sus intereses y capacidades, de forma flexible y suave. Si la educación conforme a la naturaleza requiere de estos métodos, la cortesanaestamental necesita, por el contrario, reprimir aquellos impulsos naturales, para que así emerja una nueva autoconciencia culta y civilizada.

Locke propone así un modelo pedagógico que combina la educación con la instrucción, si bien poniendo la primera en un lugar preeminente con respecto a la segunda. "La lectura, la escritura, la instrucción- escribe Locke-, todo lo creo necesario, pero no creo que sea la parte principal de la educación" (Locke, 1982: 280). Esa parte corresponde- nos dice- a aquel otro tipo de educación que se adquiere al tratar con los hombres, porque "sin virtud, sin la ciencia del mundo, sin la urbanidad- afirma- en ninguna parte de la tierra podrá encontrarse el hombre cabal y digno de estima" (Locke, 1982: 167). Adquirida esa educación, habrá terminado la tarea educativa, porque se habrá logrado que el discípulo sienta "el deseo de ser alabado y estimado" por los demás. Sin comprender el valor de ese reconocimiento la educación poco vale.

Es entonces cuando de la infancia y de la juventud habrá brotado el ser adulto civilizado. A partir de ahí "la instrucción puede ser adquirida por añadidura". Por métodos que han de ser siempre lúdicos y agradables (Locke, 1982: 281-282). Porque agradable ha de ser aquello que se adapta a los intereses de cada naturaleza 
infantil, y que se descubre cuando el sujeto entra en relación con el mundo material que le rodea. En este contexto considera Locke apropiado el aprendizaje de un oficio $^{28}$, por mucho que sea contrario a la condición del caballero, modelo de su plan educativo.

Sí, un oficio manual- nos dice, en un lenguaje que anticipa a Rousseau- (...), puesto que es preciso siempre dirigir hacia algo que sea útil la inclinación activa de los niños (...). Y aun cuando no haya más ventaja en esto que descartar y desacreditar los pasatiempos ordinarios, los juegos viciosos, inútiles y peligrosos, y mostrar cómo se puede prescindir de ellos, todavía sería una cosa digna de estimularse (Locke, 1982: 371-372 y 379).

Otros serán sin embargo los modos de enseñanza y aprendizaje cuando lo que se persigue es educar en la moralidad y en las buenas costumbres. Para ello se precisan personas que, además de tener un conocimiento profundo del medio social en el que más tarde ha de introducirse la infancia, tengan la más alta talla personal y moral. "La persona que se encarga de educar a un joven, sobre todo un joven caballero, -escribe Locke en este sentido- debe saber algo más que latín y poseer otra cosa que el conocimiento de las mismas ciencias liberales. Es preciso que sea una persona de elevada moralidad" (Locke, 1982: 330).

En suma, cuando de instruir se trata, lo principal es contar con las inclinaciones naturales de la infancia; unas inclinaciones que se hacen presentes cuando cada individuo entra en contacto con el mundo material circundante, adquiriendo una serie de habilidades prácticas. Para ello la voluntad natural así expresada no debe ser forzada exteriormente por nadie, a lo sumo puede ser guiada, flexible y suavemente, en la dirección más anhelada por cada naturaleza infantil (Locke, 1982: 372). Cuando la tarea es, por el contrario, educar, es necesario contar con personas cabales y morales que conozcan bien el mundo, el mundo cortés y civi-

$28 \quad$ Entre los oficios considera Locke, siguiendo una dilatada tradición que se remonta al mundo greco-romano, que el más apropiado es el de la agricultura. No obstante, se percibe ya en su pensamiento una clara orientación burguesa, que le conduce, como se sabe, a situar el trabajo como el origen mismo de la propiedad (Locke, 2006: 67 y ss). Prueba de ello es que dedica uno de los últimos capítulos de su tratado sobre educación a la "teneduría de libros", justificando dicha atención en que "rara vez se ve que una persona que lleve la cuenta de sus ingresos y de sus gastos, y que, por consiguiente, tenga constantemente la vista fija sobre la marcha de sus asuntos domésticos, llegue a arruinarse. Yo daría, pues, a todo caballero- nos dice- el consejo de aprender perfectamente la teneduría de libros, y de no imaginarse que esta ciencia no se ha hecho para él, bajo el pretexto de que ha nacido y está, sobre todo, en uso entre las gentes de negocios". Se percibe aquí un deslizamiento hacia la racionalidad burguesa, preocupada por sopesar los gastos y los ingresos a través de un estricto cálculo económico, y un alejamiento de la actitud noble, más atenta a la ostentación a través del gasto que a la preocupación por los ingresos (Durán, 2011: 30 y ss y 69 y ss). “...nada es más a propósito para mantener nuestros gastos en límites justos -escribe Locke-, que el hábito de tener ante los ojos el estado de nuestros asuntos en cuentas exactas y bien llevadas" (Locke, 1982: 383 y ss). 
lizado en el que más tarde infantes y jóvenes habrán de integrarse. Personas que sirvan de ejemplo a quienes se dispongan a aprender actitudes, usos y costumbres bajo su tutela. Este tipo de educación integra también la cultura, porque las personas más cultas, se entiende también que son las más educadas.

Dicho de otro modo, cuando lo que se pretende es instruir a la infancia, se parte de sus condiciones presentes, pensando en su formación para el futuro. Cuando lo que se quiere es además educarla, es preciso arrancar de una determinada tradición, que tendrán que seguir en el presente los que van a integrarse más tarde en la sociedad adulta. En el primer caso, el proceso educativo se articula a través del eje temporal presente-futuro. En el segundo, dicho eje abarca también el pasado. Mientras que el primer eje es el que orientará el programa educativo moderno; el segundo irá perdiendo progresivamente sentido.

Desde este segundo punto de vista, más orientado a la tradición, el pensamiento educativo de Locke hace gala de una mayor confianza en la sociedad que le sirve como modelo, la cortesana y civilizada, ejemplo de educación y de alta cultura. Desde el segundo punto de vista, más centrado en la instrucción, la confianza anterior se transforma en desconfianza, que se expresa como crítica a la sociabilidad cortesana. Una sociabilidad que Locke percibe como una "confusión de palabras y frases que se inventaron y emplearon para adiestrar y divertir a las personas en el arte de la discusión y que, si se las examina bien- nos dice-, probablemente se encontrará que significan poco o nada" (citado en Garin, 1987: 232-233). Desde esta última perspectiva aparece en el pensamiento educativo de Locke una sospecha de la sociedad, concebida como la fuente principal de aquellos vicios que, en su opinión, jamás podrían proceder de una naturaleza esencialmente racional y buena:

El placer- escribe- que se encuentra en hacer daño (...) no puede ser otra cosa, a mi juicio, que una inclinación adquirida y extraña a la naturaleza, un hábito que resulta del ejemplo y de la sociedad (...) Así es cómo la moda y la opinión hacen un placer de lo que no lo es naturalmente ni podría serlo. Es preciso, pues, velar con cuidado sobre esta tendencia y poner remedio desde el primer momento para sustituirla, desenvolviéndola y estimulándola, por la inclinación contraria, y mucho más natural, que nos lleva a la bondad y a la compasión, pero siempre mediante métodos lentos y dulces... (Locke, 1982: 223-24).

No obstante, esta percepción Lockeana de la bondad natural del ser humano, a la que se contrapone el mal ejemplo que en ocasiones puede ofrecer la sociedad, se atenuaba, tal como se ha visto, por el peso que en su programa educativo tenía la tradición. Por ello, su concepción de la naturaleza infantil quizás no se apartase mucho de aquella otra de raíz cristiana, aunque en una versión ya más seculari- 
zada. En efecto, en ambos casos la naturaleza es vista como inocente y llena de potencialidades. Y en los dos casos también se cree que todo ello no evita su integración mundana, necesaria para forjar la personalidad y el carácter. Desde uno y otro punto de vista no existe, pues, la intención de oponer la naturaleza al mundo. Si bien es cierto que el programa educativo de Locke dio un paso más en ese sentido, siguió manteniendo que el mundo, en su configuración cortés y civilizada, era el espejo en el que debía mirarse la gente educada.

Esta mentalidad experimentará una importante transformación cuando, en una etapa posterior, se refuerce mucho más la confianza en la naturaleza humana, afirmándose sin reservas la absoluta verdad que en ella anidaba, y se disipe al mismo tiempo aquella otra confianza que anteriormente se tenía en el mundo, considerado a partir de ahora la fuente de todos los males. Cuando esto ocurra, se habrá borrado por completo la huella de la tradición bajo la fuerte pisada de la mentalidad educativa moderna. El primero en inicar este camino fue Jean Jacques Rousseau, cuyo pensamiento es ya plenamente moderno.

\subsubsection{Rousseau: la educación por la naturaleza}

La desconfianza con respecto a la sociedad, que, tal como se ha visto, ya se advertía en Locke, se convertirá en Rousseau (1712-1778) en puro rechazo. “Todo está bien al salir de las manos del autor de las cosas: todo degenera entre las manos del hombre", dejó escrito en frase célebre en su principal obra educativa, el Emilio, publicado originalmente en 1762 (Rousseau, 2002: 37). El pensamiento educativo de Rousseau se construye así queriendo derribar primeramente toda la obra civilizatoria, en busca de una autenticidad que sólo comenzaría asomar una vez quitada esta capa de engaño y de artificio (Taylor, 1994: 62 y ss). "Las sospechas, las sombras, los temores, la frialdad, la reserva, el odio, la traición- escribió- se ocultaban sin cesar bajo ese velo uniforme y pérfido de cortesanía, bajo esta urbanidad tan ponderada que debemos a las luces de nuestro siglo" (Rousseau, 2003a: 175). Esa serie de apariencias y de engaños que conforman lo que Rousseau entiende que es la civilidad cortesana, es la que impide que brote lo más auténtico del ser, para poder así edificar una nueva comunidad transparente y clara. Esa comunidad que debió constituir el estado primigenio del ser humano, y que la civilización ha sepultado:

El alma humana- escribe Rousseau-, alterada en el seno de la sociedad por mil causas constantemente renacientes, por la adquisición de una multitud de conocimientos y de errores, por los cambios ocurridos en la constitución de los cuerpos, y por el choque continuo de las pasiones, ha cambiado, por así decir, de apariencia, hasta el punto de ser casi irreconocible (2003b: 220). 
Rousseau quiere superar esta situación históricamente heredada en busca del feliz reencuentro entre el ser y el parecer, esas dos unidades que un día estuvieron unidas y que la civilización no ha hecho más que escindir. "Ser y parecer- dijo-llegaron a ser dos cosas totalmente diferentes, y de esta distinción salieron el fausto imponente, la astucia falaz y todos los vicios que son su cortejo" (Rousseau, 2003b: 290).

Persiguiendo esa imaginada y originaria arcadia feliz, la hallará representada en una naturaleza infantil inocente y pura, no contaminada aún por los males del mundo. De ella va a partir para construir la nueva sociedad, porque si en la humanidad reside el error a ella habrá que volver para subsanarlo (Starobinski, 1983: 21-22).

Rousseau pretende así restaurar la unidad perdida, a partir de una infancia inocente y bondadosa, con inmensas potencialidades. Una infancia imaginada fuera de la sociedad, provista de su sola naturaleza y del mundo natural que le sirve de cobijo, y que la surte de todo cuanto necesita. Así debió de ser, cree nuestro autor, aquella comunidad originaría que él ha imaginado, y que ahora quiere escenificar en su Emilio.

El programa educativo rousseauniano tendrá de este modo como principal objetivo formar al niño sin pensar en el adulto, porque éste es el producto de la civilización que ha conducido al error, y en aquél reside, por el contrario, esa verdad primera que hay que recuperar; una verdad que anida en lo más profundo de su naturaleza, a la que por ello hay que seguir y respetar. Nuestro autor profesa así una confianza, todavía mayor que la de Locke, en las potencialidades y en la bondad de la naturaleza humana. Una bondad que se manifiesta sobre todo en la infancia, la edad que más cercana está a ella. "Observad la naturaleza- escribió- y seguid la ruta que os marca. Ella ejercita continuamente a los niños" (Rousseau, 2002: 55).

Se quiebra así definitivamente el hilo con el pasado, porque lo que así se pretende es comenzar un nuevo relato a partir de aquella edad que precisamente menos pasado tiene, la infancia, que de este modo puede crear su vida desde el presente sin ningún lastre civilizatorio que la perturbe. De la infancia partirá por tanto Rousseau, con la intención de edificar una sociedad futura limpia y transparente.

Se invierte así la categoría de las edades, ya que la infancia sustituye como modelo al ser humano adulto, dejando de ser una mera etapa de preparación para esa edad futura. "Hay que considerar al hombre en el hombre, y al niño en el niño", afirmó Rousseau. Y recomendó, "dejad que la infancia madure en los niños" (Rousseau, 2002: 104 y 126).

El educador ha de saber, pues, reconocer esa naturaleza en cada uno de sus pupilos (Rousseau, 2002: 126). No a través de lo que él dice y ordena, sino de lo que el niño apetece y hace. "Pensad- escribe Rousseau- que raramente os toca pro- 
ponerle lo que debe aprender; es a él a quien corresponde desearlo, buscarlo, hallarlo" (2002: 263). Y con seguridad buscará y hallará lo que más relacionado esté con sus propias necesidades materiales y con su talento (Rousseau, 2002: 275-82). Emilio se educa así por su propia experiencia; más por el contacto con las cosas, que por lo que el educador pueda trasladarle del mundo exterior a través de sus propias palabras. "No deis a vuestro alumno- afirma Rousseau- ninguna clase de lección verbal, sólo debe recibirlas de la experiencia" (2002: 123). La educación se convierte aquí en verdadera instrucción, pues supone la adquisición de una serie de habilidades prácticas a través de la relación que los individuos establecen con las cosas de la naturaleza, sin la intermediación de nadie que se proponga enseñar otras realidades externas a esta. Emilio se instruye, en efecto, mediante el fructífero encuentro entre su yo y la naturaleza. Todo lo demás son máscaras que ocultan lo verdaderamente auténtico. La educación se inclina de este modo del lado del que aprende más que de quien enseña.

En relación con la naturaleza satisface también Emilio sus necesidades, para lo que precisará la cooperación de sus congéneres. Pronto comprenderá, por tanto, la conveniencia de relacionarse socialmente, "pues un hombre que quiera considerarse como un ser aislado, sin conexión ninguna con nada y bastándose a sí mismo, no podría ser sino miserable" (Rousseau, 2002: 284). Emilio precisará para ello aprender un oficio, el que más esté de acuerdo con sus capacidades e intereses (Rousseau, 2002: 283-84).

Supongamos diez hombres -escribe Rousseau-, cada uno de los cuales tiene diez clases de necesidades. Es menester que cada uno se aplique, para lo indispensable, a diez clases de trabajo (...) Formemos una sociedad con esos diez hombres, y que cada uno se aplique, para él sólo y para los otros nueve, al género de ocupación que mejor le vaya (...) He ahí el principio aparente de todas nuestras instituciones (Rousseau, 2002: 283).

De este modo la sociedad, que como entidad instituida y heredada despertaba en Rousseau sospecha y rechazo, emerge como una realidad edificante, emanada de la interacción fructífera entre el hombre y la naturaleza. Sin ningún tipo de mediaciones ni ocultaciones, transparente y comprensible para cada uno de sus miembros.

Del individuo natural y aislado se habría transitado así al hombre integrado en "un organismo único en el que todas las partes se completan" (Starobinski, 1983: 138). Ese ser humano así constituido, ya no será el de la sociedad civilizada, sino el de la comunidad perfectamente integrada; esa comunidad en la que ya no hay velos que oculten la verdad de las cosas, porque esa verdad reside en el encuentro transparente e inmediato entre unos yoes y los otros. 
Mientras que la metáfora civilizatoria estaría representada por el teatro, en el que la naturaleza de los actores se oculta detrás de sus máscaras, la de la comunidad rousseauniana se escenificaría en la fiesta, en la que, una vez caídas aquellas máscaras, se produce la efervescencia de un único yo colectivo. Y puesto que a esa situación se ha llegado a través del feliz encuentro entre el hombre y la naturaleza por medio de su trabajo, nada mejor que la fiesta de la vendimia para representar${ } \mathrm{la}^{29}$. Allí, en esa relación festiva, emerje una absoluta igualdad libre de mediaciones, porque lo que en realidad existe es una sola conciencia colectivamente expresada (Starobinski, 1983: 133 y ss; 1987: 100 y ss).

Rousseau ha querido de este modo mostrar lo que una buena educación puede, capaz de transformar un espíritu vulgar en el mejor de los seres humanos (Rousseau, 2002: 290-91). Un ser libre de toda clase de determinaciones, salvo aquellas que él mismo se haya impuesto en comunión con sus iguales.

A partir de Rousseau se asienta, pues, la idea de que la educación puede cambiarlo todo; de que mediante su acción es posible crear un hombre nuevo. Para lo cual se hace imprescindible tomar como modelo la infancia, por carecer precisamente de pasado, transformándola a partir de su propia naturaleza. Una naturaleza a la que hay que conducir según sus propios intereses y potencialidades, que se manifiestan en la relación que establece con el mundo físico que le rodea. Es así como la humanidad entera se abrirá a un futuro lleno de oportunidades y abierto al progreso.

La educación, que hasta este momento aún no había sido pensada con independencia del mundo adulto, se convierte de este modo en un programa a la medida de la infancia. Un programa que rechaza toda la tradición anterior para amoldarse a las inclinaciones naturales de cada individuo. Se invierten así las jerarquías de las edades, y también las del mundo. El pasado, con toda su carga social, cultural y simbólica, deja, en efecto, de orientar el futuro. Éste se construye desde la novedad que representa cada naturaleza infantil como proyecto de perfectibilidad indefinida. Como el método para acercarse a cada una de estas naturalezas es, además, único y universal, se abre la posibilidad para el desarrollo de una ciencia pedagógica autónoma que oriente el proceso educativo. Un proceso que tendrá una dimensión fundamentalmente práctica, porque se origina en la interacción entre los sujetos y el mundo físico. El aprendizaje de habilidades adquirirá así cada vez más importancia frente a la enseñanza de conocimientos (Arendt, 2003a: 282).

29 El trabajo agrícola aparece en Rousseau, siguiendo una tradición que se remonta a la antigüedad clásica, y cuyo antecedente más inmediato estaría en el pensamiento fisiocrático, como la más noble de todas las actividades. Ella es, en efecto, la fuente de toda riqueza, y la que permite también que el ser humano lleve una vida independiente (Durán Vázquez, 2006 y 2011). Así se puede leer en el Emilio que "la primera y más respetable de todas las artes es la agricultura" (Rousseau, 2002: 276). 
Con Rousseau se produce una auténtica revolución copernicana en el campo educativo (Rénaut, 2002: 336). Su pensamiento ejercerá una enorme influencia en los más diversos sectores ideológicos, desde en las órdenes religiosas católicas hasta en el liberalismo, y, por supuesto también, en el anarquismo y en el socialismo (Bowen, 1985 III: 262-66; Dietrich, 1976; Dommaget, 1972).

Sus ideas penetrarán también la nueva sensibilidad burguesa, muy receptiva a algunas de las obras que a comienzos del siglo XIX las popularizaron (Cook, 2004: 29-30; Robertson, 1994: 461; Varela, 1991: 75-76; Stone, 1990: 256; Ariès, 1987: 443). La familia burguesa, en efecto, tendrá una especial preocupación por la educación de la infancia, tanto en el plano sentimental como en el formativo. Y para ello se replegará sobre el ámbito privado familiar, para educar a sus hijos. En esa esfera, más próxima y afectiva se desarrollarán unas relaciones paterno-filiales más próximas y afectivas, a salvo de la influencia del mundo externo, percibido cada vez más como engañoso, impersonal y frío. Para esta tarea sin duda Rousseau podía ser una buena fuente de inspiración. Como lo era también para aquel otro propósito de la burguesía, formar a seres capaces y útiles para el desempeño de las distintas ocupaciones que demandaba la naciente sociedad industrial (Varela, 1991: 77).

La influencia de Rousseau se dejará sentir, asimismo, en la voluntad de los distintos gobiernos salidos de las Revoluciones liberales de reformar la instrucción pública, para crear así ciudadanos virtuosos, dispuestos a contribuir a su desarrollo personal y al de la república. En donde primero se verá aflorar esta nueva actitud será en el periodo revolucionario francés ${ }^{30}$, en figuras como Condorcet (2000). En este momento se asentará plenamente el principio de la educación vinculada a una ciudadanía igualitaria y libre (Luzuriaga, 1994: 158; Monnier, 1990; Julia, 1989ab y 1981: 18-19). El desarrollo de un sistema de educación nacional animará también la mayoría de las reformas educativas que se llevarán a cabo tanto en Europa como en América a lo largo del siglo XIX (Luzuriaga, 1994: 181).

La creencia en el poder casi taumatúrgico de la educación para cambiar la sociedad hacia un futuro abierto de progreso, y su consideración como una de las principales preocupaciones públicas, fue doctrina común de todas las teorías educativas de inspiración rousseauniana. El pedagogo de más renombre que primeramente contribuyó a difundir su pensamiento por toda Europa fue Pestalozzi (1746-1827) (Bowen, 1985 III: 287; Sommerville, 1982: 132-33), quien manifestó, en efecto, como antes lo había hecho su maestro, una gran desconfianza de la sociedad, seguida de una confianza casi absoluta en la naturaleza humana. "El hom-

$30 \quad$ No obstante, fue Federico II de Prusia (1712-1786), cuyo antecesor había creado el primer sistema de educación pública, quien primero reconoció explícitamente el legado rousseauniano (Luzuriaga, 1994: 155). 
bre- escribió- es bueno y quiere lo bueno (...), y si es malo, es porque seguramente le han cerrado el camino en el cual quería ser bueno" (Pestalozzi, 1965: 117). Todo lo que proviene del mundo humano debe ser así cuestionado y rechazado, y afirmada sin embargo la verdad que encierra la naturaleza infantil. Así, frente a la confianza que tenía la educación tradicional en la transmisión a través de la palabra, hasta el punto de considerar irracionales a quienes aún no la comprendían, Pestalozzí confía ciegamente en la palabra del niño, la voz de su misma naturaleza. "El mejor libro de enseñanza en el siglo que acaba de terminar- escribió- ha olvidado que el niño debe aprender a hablar antes de que se pueda hablar con él" (Pestalozzi, 1965: 173). Todo proceso educativo ha de originarse así en el sujeto mismo que aprende, y no en alguien exterior a él que le traslade una serie de conocimientos. "Amigo- afirmó Pestalozzi- todo lo que soy, todo lo que quiero y todo lo que debo ser proviene de mí ¿No deben también mis conocimientos proceder de mí?” (Pestalozzi, 1965: 124).

No obstante, el éxito y la rápida propagación de la doctrina rousseauniana no se debió solamente a la influencia que ejerció en pedagogos que, como Pestalozzi, la recibieron y la difundieron. Dicho éxito estuvo también motivado, como se señaló anteriormente, por la profunda huella que dejó en movimientos ideológicos de uno y de otro signo, y especialmente en el marxismo y en el socialismo. En casi todo su ideario educativo se advierte, en efecto, la huella Rousseauniana. Algunos de los socialistas utópicos más destacados, como Owen (Owen, 1985) y Fourier (Fourier, 1989), incorporaron casi todos sus principios para construir una teoría educativa que, en líneas generales, estará en la base de las concepciones educativas socialistas (Manacorda, 1972). La confianza en las enormes posibilidades de la naturaleza humana; una naturaleza desvirtuada por la acción perversa de la sociedad, que sólo cabía restaurar por medio de métodos educativos científicos y racionales, para conformar así una sociedad más justa e igualitaria, es parte esencial del credo rousseauniano. Como lo es también la percepción de la infancia como el núcleo principal del proceso educativo, una infancia que los adultos tendrían que guiar respetando sus distintas inclinaciones naturales, sin perturbar su esencia con gruesas lecciones verbales. Desde este punto de vista, la actividad educativa dejará de mirar definitivamente al pasado, el origen de todos los errores que tienen a la humanidad encadenada, para vincularse a los que están más purgados de aquellos males, cada una de las naturalezas infantiles, que así podrán progresar sin ningún obstáculo, casi indefinidamente. La herencia rousseauniana puede percibirse, asimismo, en la concepción socialista y marxista de la educación como una tarea esencialmente práctica en el contexto de una sociedad articulada alrededor del trabajo.

Todas estas ideas de raíz rousseauniana, con distintos matices, fueron compartidos por el marxismo (Gutiérrez Zuluaga, Manacorda, 1972: 321 y ss), por el 
anarquismo, y también por el socialismo más reformista, hasta integrar el credo educativo de estos movimientos políticos. Y se difundirán profunda y extensamente a medida que lo hacían dichas ideologías.

Entre finales del siglo XIX y comienzos del XX dichos principios recibieron una nueva reformulación, tanto en Europa como en Norteamérica, primero en el contexto ideológico del socialismo reformista, y más tarde en la denominada Escuela Nueva (Varela, 1991: 76).

Los dos próximos epígrafes estarán dedicados a describir, en primer lugar el pensamiento educativo del socialismo, el marxismo y el anarquismo, para seguidamente prestar atención a las ideas educativas de Émile Durkheim y John Dewey, que entre finales del siglo XIX y comienzos del XX sentaron las bases del programa educativo del socialismo reformista, que influirá ampliamente en la obra educativa de las democracias occidentales.

\subsubsection{Socialismo, marxismo y anarquismo. La educación a través del trabajo}

Las corrientes marxistas y socialistas, y asimismo las anarquistas, incorporaron, en efecto, el grueso de la doctrina pedagógica rousseauniana, y contribuyeron a difundirla a medida que se extendía su influencia.

Desde este punto de vista, estas ideologías quizás no tengan tanto interés por la novedad que representan, como por la influencia que ejercieron en las corrientes pedagógicas de signo progresista.

Los intelectuales y activistas vinculados a dichas corrientes ideológicas tuvieron una fe casi ciega en la capacidad casi absoluta de la educación para transformar por completo al ser humano y a la colectividad en su conjunto.

Tómese, pues, -escribió el socialista utópico Robert Owen- las disposiciones para que se admita el debido y regular ejercicio de todas las dotes y las facultades de nuestra naturaleza, acordes con la fuerza y capacidad del individuo, y la enfermedad, el vicio, la decepción, y la miseria pronto desaparecerán de la tierra (Owen, 1985: 223).

No obstante, para que dicha transformación se produjese, tanto Marx como los socialistas y los anarquistas, de uno y otro signo, consideraron que era necesario acabar con la sociedad tal como había existido hasta ese momento. Una sociedad, basada en la propiedad privada y en la división del trabajo, que había corrompido la humanidad, alienándola, impidiendo que brotase su verdadera naturaleza, a partir de la cual sería posible construir una comunidad más rica, libre, igualitaria y justa (Marx, 2001; 1984). 
Este libro- escribe Robert Owen en el prefacio de una de sus principales obras- ha sido escrito para acelerar este cambio excepcional al explicar la causa de la maldad humana, los medios de removerla, y el trazar un nuevo mundo moral (...) Un mundo en el que la justicia, por primera vez, será hecha a la naturaleza mediante todo sentimiento, facultad y capacidad inherente a cada niño, siendo cultivado hasta su pleno desenvolvimiento (1985: 171).

Si para el socialismo más revolucionario, así como para el anarquismo, la construcción del nuevo mundo no podría comenzar sino era sobre las ruinas del anterior, las corrientes más reformistas apostaron por la renovación más que por la destrucción. Pero en uno y otro caso había una confianza casi absoluta en las inmensas posibilidades de una educación racionalista y científica, orientada a desarrollar las potencialidades casi infinitas que se atribuían a la naturaleza infantil. "Solamente cuando los seres humanos sean de esta manera educados y puestos en circunstancias externas en concordancia con tal educación, y se permita que actúen al unísono con su naturaleza- escribió Robert Owen-, se manifestará lo que los hombres pueden llegar a ser, general e individualmente" (1985: 203-204).

La infancia se convertiría así, tal como creyera Rousseau, en la piedra angular sobre la que se podría edificar la nueva sociedad anhelada. Porque ella era también la que menos tenía que ver con el pasado, fuente de todos los males, y la que más cerca estaba, por el contrario, de la verdad esencial que reside en su naturaleza. La infancia será, por tanto, la primera en ser educada.

Es pues por la educación que hay que comenzar- escribe el socialista utópico Fourier-, tanto más cuanto que ésta sería la rama del mecanismo que debería organizarse la primera, porque no estando los niños muy falseados por los perjuicios y las desconfianzas, serán más dóciles a la atracción que los padres (1989: 197).

Una atracción que se despertará muy pronto cuando así se manifiesten sus distintas vocaciones. "En el niño hay muchos gérmenes de facultades industriales, de numerosas vocaciones- afirmó el anarquista Ferrer i Guardia-, pero esas vocaciones no se manifestarán sino en el medio y en las circunstancias favorables a su exteriorización" (1978: 119).

Una vez creadas esas circunstancias, habrá que buscar en la infancia lo que en ella hay de más auténtico, indagando en su particular naturaleza. De ese modo podrá ser conducida hacia cualquier meta.

Los niños son, sin excepción, seres compuestos, pasivos y maravillosamente hechos- escribió Robert Owen-; si uno los somete a un tratamiento preciso, tanto previo como posterior, fundado en un conocimiento exacto de la cuestión, uno puede dotarlos colectivamente de cualquier carácter humano. Y 
aunque estos seres, como todas las demás obras de la naturaleza, presentan innumerables variedades, poseen esta plasticidad que, gracias a una perseverancia juiciosamente dirigida, puede modelárseles a imagen de la misma razón (1985: 105).

Ayudado por esa plasticidad natural y por las potencialidades casi infinitas de su naturaleza, el educador sólo tendrá que averiguar a dónde ella tiende.

No se ve- dijo Proudhon- que en todo hombre la actividad obedece a una tendencia particular? ¿Qué esa tendencia, necesariamente especial, es el principio de la capacidad futura? ¿Qué al maestro le corresponde adivinarla, apoderarse de ella y situarse en ella como en un foco para, desde allí, actuar en todos los sentidos y en todas las direcciones? (citado en Dommaget, 1972: 287).

Toda buena educación tratará, pues, de seguir dichas tendencias a través del más sencillo de los métodos, poniendo a cada naturaleza infantil en relación con las cosas, y apartándola por el contrario de las palabras, que son el signo de una tradición que, por opresora, será rechazada de pleno. Mientras que las palabras someten, en efecto, desde fuera la voluntad de quien las percibe como ajenas a su naturaleza, las cosas despiertan el interés del sujeto de forma espontánea, por lo que las enseñanzas que de ellas provienen pueden recibirse suave y tiernamente, como si de un juego se tratase. "La hermosura y la comodidad de las escuelas, la paciencia y la ternura de los instructores- afirmó el socialista utópico Cabet-, así como también su habilidad, la sencillez de los métodos, la claridad de las demostraciones, la reunión del estudio con los juegos, todo concurre- dijo- a la consecución del objeto" (Cabet, 1985: 292). Y si esta consecución se dificulta- observa Rober Owen- no será por culpa de los niños, sino del método (Citado en Dommaget, 1972: 198).

Toda educación se transforma así en una acción por medio de la cual el propio aprendiz manipula y trasforma los objetos de la naturaleza siguiendo su particular interés, con un propósito útil y práctico, como si fuese un juego ${ }^{31}$. "Todo juego bien dirigido se convierte en trabajo, como todo trabajo en juego", afirma el anarquista español Ferrer i Guardia (1978: 112). Y toda educación se desenvuelve también como trabajo, ya que es a partir de esta actividad como los sujetos se humanizan, desarrollando todas sus potencialidades. "Puesto que el hombre- escribe Marx- se ha arrancado del reino animal por medio del trabajo y la formación del hombre se realiza a través del trabajo, no puede haber formación sin trabajo ni, a la inversa, trabajo sin formación" (citado en Dietrich, 1976: 51).

\footnotetext{
Es necesario precisar, sin embargo, que, a diferencia de los socialistas utópicos, e incluso de los anarquistas, Marx rechazó la idea de vincular el aprendizaje con el juego. Ni el trabajo puede ser un juego, ni juego puede ser tampoco la educación combinada con el trabajo (Manacorda, 1969: 117).
} 
Esta condición del ser humano, como ser que se autoproduce a través del trabajo, está impresa en la naturaleza humana, por mucho que la civilización la haya ocultado. Y esa huella es casi indeleble en donde el peso de la civilización es más débil, tal como ocurre en la primera infancia. Por eso resulta más fácil educarla, siempre que se sigan sus propias tendencias naturales, que necesariamente se expresarán en las diversas ocupaciones laborales.

$¿$ ¿Ha nacido vuestro alumno emprendedor y desvastador? -afirma Proudhon¿Le gustaría ejercitarse en la madera, la piedra o el hierro? (...) ¡Guardaos de comenzar con él por las abstracciones y las leyes! Dadle herramientas para manejar, árboles o piedras para escuadrar; ya vendrá el momento en que de la práctica se eleve a las teorías (citado en Dommaget, 1972: 287).

Se aprende, por tanto, haciendo; y este hacer es trabajar. Toda buena educación tendrá que estar, pues, relacionada con el trabajo. "Es evidente- escribe Robert Owen- que la educación y la instrucción deben ser entendidas en estrecha relación con los trabajos de la colectividad" (Owen, 1968: 107). Así lo cree también Marx, que reconoce en este aspecto su deuda con Robert Owen ${ }^{32}$ :

Del sistema fabril- escribe-, como podemos ver en detalle en la obra de Robert Owen, brota el germen de la educación del futuro, que combinará para todos los niños a partir de cierta edad el trabajo productivo con la educación y la gimnasia, no sólo como método de acrecentar la producción social, sino como único método para la producción de hombres desarrollados de manera omnifacética (citado en Cabrera, 1986).

La educación vinculada al trabajo no sólo potenciará, pues, las distintas capacidades humanas, sino que hará incrementar también la riqueza, y por tanto el bienestar de la humanidad sobre la tierra.

No obstante, este tipo de educación no se reduce únicamente a una mera enseñanza técnica; requerirá asimismo la participación directa de la infancia, en unas condiciones no alienantes, en el proceso productivo. Y todo ello desde edad bien temprana:

Consideramos- escribe Marx- que es progresiva, sana y legítima la tendencia de la industria moderna a incorporar a los niños y a los jóvenes a cooperar en el gran trabajo de la producción social, aunque bajo el régimen capitalista ha sido deformada hasta llegar a su abominación. En todo régimen social razona-

32 Esta idea aparece expresada en distintas obras de Marx, en particular en el Manifiesto Comunista (1981a), en las Instrucciones sobre diversos problemas a los delegados del Consejo Central Provisional, texto preparado para su intervención ante la Asociación Internacional de Trabajadores reunida en Ginebra en 1866 (1981b); en el Capital (1999), y en la Crítica al Programa de Gotha de 1875 (1975). Ver Gutiérrez Zuluaga, 1975: 111 y ss.; Manacorda, 1969: 44 y ss; Dommaget, 1972: 330. 
ble cualquier niño de 9 años de edad debe ser un trabajador productivo, del mismo modo que todo adulto apto para el trabajo debe obedecer la ley general de la naturaleza, a saber: trabajar para comer y trabajar no sólo con la cabeza sino también con las manos (citado en Cabrera, 1986).

Con la cabeza y con las manos, porque el trabajo lo engloba todo; es pensado al mismo tiempo como actividad intelectual y práctica. "En la instrucción integralescribe Bakunin-, al lado de la enseñanza científica o teórica, debe de haber necesariamente la enseñanza industrial o práctica. Sólo así se forma el hombre completo: el trabajador que comprende y sabe" (1979: 49). En este tipo de educación verá Marx también un beneficio para una vida más diversa y saludable: "En el sistema mitad trabajo y mitad escuela- afirma-, cada una de las dos ocupaciones reposa y distrae a la otra, y el niño se haya mejor que si se le clavara constantemente a una de ellas" (citado en Dommaget, 1972: 331-332).

Y además de este modo se pondrá también fin a aquella división artificial entre enseñanza técnica e intelectual, que es el fruto de una división del trabajo mantenida a lo largo de la historia. Una división que "coloca la teoría antes que la práctica" (Fourier, 1989: 244), y que ha sido responsable de convertir a un ser humano libre y lleno de potencialidades en otro alienado e incompleto (Marx, 2001: 107 y ss; 1999: 349).

La industria practicada en común, según un plan establecido de acuerdo con el conjunto de la sociedad- señala Engels en sus principios del comunismo de 1847-, implica hombres completos, cuyas facultades se hayan desarrollado en todos los sentidos y que estén en condiciones de tener una visión clara de todo el sistema productivo. La división del trabajo, que hace de uno un campesino, de otro un zapatero, del tercero un trabajador industrial y del cuarto un especulador de bolsa, está desde ahora mismo ya socavada por el maquinismo y desaparecerá completamente. Para educarse, los jóvenes podrán recorrer rápidamente todo el sistema productivo, a fin de que puedan pasar sucesivamente por las diversas ramas de la producción, según lo pidan las diversas necesidades sociales y sus propias inclinaciones. Por ello, la educación les liberará del carácter unilateral que imprime en cada individuo la actual división del trabajo. De esta forma, la sociedad, organizada según el modelo comunista, dará a sus miembros ocasión para desarrollar tanto sus sentidos como sus aptitudes (Marx y Engels, 1978: 154).

De la alienación se pasaría así, en la futura sociedad comunista, a una auténtica polivalencia, pues "cada individuo- escribe Marx- no tiene acotado un círculo exclusivo de actividades, sino que puede desarrollar sus aptitudes en la rama que mejor le parezca" (1984: 46). De este modo, no sólo habrá un mayor enriquecimiento para cada uno de los individuos, sino que se enriquecerá también la sociedad en su conjunto. "Con el desarrollo de los individuos en todos sus aspectos- 
afirma Marx-, (crecerán) también las fuerzas productivas y (correrán) a chorro lleno los manantiales de la riqueza colectiva" (Marx, 1971: 24).

Para desarrollar esa polivalencia, esa omnilateralidad, tal como Marx la denomina, toda formación escolar debe prestar atención a las ciencias naturales, porque todo ser humano es, en efecto, un ser natural que se desarrolla y satisface sus necesidades en contacto con la naturaleza. Dentro de este ámbito deben incluirse también los conocimientos técnicos, necesarios para incrementar la productividad y para otorgar un mayor bienestar material a los seres humanos sobre la tierra. Todo sistema formativo tiene que procurar, además, conocimientos de gramática, porque los seres humanos se desarrollan a través de una relación cooperativa con otros miembros de su especie, creando así un particular lenguaje. Al margen de estas materias básicas, los conocimientos humanísticos no tienen por qué estar incluidos en el programa escolar, ya que se prestan a interpretación ideológica. Además, para adquirirlos no hay nada mejor que la interacción práctica y personal con quienes los poseen (Gutierrez Zuluaga, 1975: 136 y ss).

En las escuelas elementales- y más aún en las superiores- (escribe Marx), no hace falta autorizar disciplinas que admiten una interpretación de partido o de clase. En las escuelas no hay que enseñar más que gramática, ciencias naturales (...) las reglas gramaticales no cambian, ya sea un conservador clerical o un libre pensador quien las enseñe. Las materias que admiten conclusiones diversas no tienen por qué ser enseñadas en las escuelas; los adultos pueden ocuparse de ellas bajo la dirección de maestros (Marx y Engels, 1978: 158).

La mentalidad marxista, como la socialista y anarquista, no puede ser más positivista. Siguiendo el punto de vista rousseauniano, sólo se aceptan aquellos saberes que tienen por objeto las cosas de la naturaleza, con una finalidad útil y práctica. En esto, como en otras muchas de sus ideas educativas, Marx no se aparta de sus predecesores socialistas. Uno de los más insignes pioneros de esta corriente, Saint-Simon, se pregunta:

¿Cuál es la instrucción que se debe dar al pueblo? La instrucción que más necesita el pueblo- responde- es la que puede hacerle más capaz de ejecutar bien los trabajos que se le puedan confiar. Ahora bien, algunas nociones de geometría, de física, de química y de higiene son indiscutiblemente los conocimientos que le serían más útiles para gobernarse en la práctica de la vida (...). El sistema de instrucción para las escuelas primarias- concluye- lo deben organizar, pues, los sabios que profesan las ciencias positivas (Citado en Dommaget, 1972: 176).

Todos los demás conocimientos que no entren dentro de esta categoría deben quedar por tanto fuera de la enseñanza, porque responden, tal como pensaba Marx, a distintos intereses de clase. Se huirá así de la enseñanza libresca; pura 
verborrea procedente de una tradición que se maldice y repudia por ser fuente de todo tipo de corrupciones. Frente a este tipo de enseñanza basada en las palabras, se afirma rotundamente, como antes lo hiciera Rousseau, aquella otra que tiene por objeto las cosas. Así lo creía también el anarquista español Ferrer i Guardia, para quien "las lecciones de las cosas" deberían "sustituir a las lecciones de las palabras, que tan amargos frutos han dado- dice- en la educación de nuestros compatriotas" (1978: 80).

Si las cosas deben imponerse a las palabras, porque éstas son parte de la herencia errónea que los mayores han legado a los más jóvenes; mientras que aquellas responden a la verdad que brota de la interacción entre el ser humano y la naturaleza, parece evidente que los adultos no están en mejor posición para educar a la infancia. Incluso se diría que debieran aprender de ésta. "Los niños deben educar a los padres", es una frase que se atribuye a Marx (Dommaget, 1972: 325). O al menos no ser educados por ellos. Porque, como se ha dicho, sólo partiendo de la infancia será posible el nacimiento de una nueva sociedad que se encuentre con aquella otra originaria, en la que los seres humanos se relacionaban entre ellos, y con su entorno natural, igualitaria, cooperativa y libremente (Marx, 2001: 139).

Llegado a ese momento las palabras volverán a tener sentido, porque ya no serán el fruto de las opiniones humanas, sino que emanarán de una comunidad de productores en la que todos se aplican al mismo fin productivo. Un fin que se sintetiza en el siguiente principio, "ide cada cual, según sus capacidades; a cada cual según sus necesidades!” (Marx, 1971: 24). Entonces, sólo entonces, las palabras podrán volver a ser proclamadas, porque encerrarán esta verdad fundamental y única.

El pensamiento educativo marxista y socialista logró una gran difusión y popularidad, paralela a la que también alcanzaron estas ideologías. Este hecho es el que lo hace especialmente relevante, más allá de su originalidad, que, tal como se ha visto, es bastante relativa, pues en muchos aspectos no hizo más que ampliar el legado rousseauniano.

Entre finales del siglo XIX y el primer tercio del XX los principios educativos socialistas y marxistas fueron reformulados por destacados intelectuales vinculados al ámbito de la sociología, la filosofía y la pedagogía, convirtiéndose en el núcleo de la ideología meritocrática que legitimará la obra educativa de los nuevos Estados liberales y democráticos. En este sentido tuvieron un papel destacado el sociólogo francés Emile Durkheim y el filósofo y pedagogo norteamericano John Dewey. 


\subsubsection{La educación en la sociedad democrática e industrial: el programa educativo de Emile Durkheim y John Dewey}

Émile Durkheim y John Dewey elaboraron sus respectivas obras educativas orientadas a una sociedad democrática e industrial, en la que la educación desempeñase un papel clave desde el punto de vista del progreso, la igualdad y la justicia social. Aun así, como luego veremos, el pensamiento educativo de Dewey tiene un acento mucho más pedagógico que el de Durkheim. La obra de este último se inscribe, en efecto, en el ámbito de una nueva ciencia social, la sociología, destinada a explicar y a justificar la necesidad de la educación como hecho social y moral clave para la integración de la naciente sociedad industrial. El modo en cómo lo argumentó será el tema del siguiente epígrafe.

\section{Émile Durkheim: reforma social y educación moral}

Émile Durkheim (1858-1917) construyó una teoría social y educativa que integraba los principios del socialismo reformista y los del liberalismo, en el contexto de la emergente sociedad industrial (Lukes, 1984: 338). Dicha teoría fue asumida por el programa educativo de la III República francesa (leyes Ferry 1881-82), pasando a integrar el ideario de la escuela republicana (Resende, 2010: 131; Lukes, 1984: 77; Ramos, 1982: 10).

La Educación era parte fundamental de la propuesta sociológica durkheimiana, pues estaba destinada a colaborar en la creación de una nueva moral que sustituyese a la anterior afectada por una profunda crisis. Dicha crisis provenía, según Durkheim, de que "la disciplina colectiva, en su forma tradicional, había perdido su autoridad", sin que hubiese emergido "ninguna otra que ocupase su lugar. Antiguos deberes- decía- han perdido su fuerza de imposición, sin que veamos aun claramente y con mirada segura cuáles son nuestros nuevos deberes" (Durkheim, 2002: 92-99).

Había que crear, pues, una nueva moral. "Nuestro primer deber actual- escribió Durkheim- consiste en construirnos una nueva moral" (citado en Ramos, 1982: 44). La sociología durkheimiana arranca así con este firme propósito. Un propósito que era el producto de una profunda inquietud con respecto a la sociedad de su tiempo, ante lo que él percibía como la ausencia de creencias colectivas que conformasen una moral común. La obra sociológica de Durkheim se desarrolla de este modo como un intento de explicar las causas de esta crisis moral, para después proponer un plan de reforma social, "despertando la fe en un ideal común" (Durkheim, 2002: 99-100). Un ideal del que no quepa dudar, de forma que 
todo el mundo se adhiera firmemente a él. Sólo de este modo se conseguirá la integración social, poniendo remedio a la desestabilización de la sociedad.

Ahora bien, este ideal ya no podía tener su origen en antiguas creencias, que ya no movían como antes a las gentes, en socieades tan secularizadas como las modernas. En dichas sociedades la razón triunfa cada vez más sobre la fe, por lo que ya no es posible que las personas se sometan a los que dicen ejercer la autoridad en su nombre. Y aun así, consideraba Durkheim, seguía siendo necesario contar con alguna fuerza que vincule a los miembros de la sociedad; no porque les inspire un temor reverencial, sino porque se reconozcan racionalmente en ella, ya que de algún modo les infunde respeto. Un respeto que por ello tiene que emanar de principios que "no deben sustraerse a la discusión, haciendo ídolos a los que, por así decir, el hombre no ose levantar los ojos" (Durkheim, 2002: 71).

Ahora bien, ¿cuál es el origen de tales principios?; ¿quién los sostiene? "Desde el momento- afirma Durkheim- que se prohíbe recurrir a ideas teológicas por encima del individuo, no existe más que un solo ser moral, empíricamente observable, que es el que forman los individuos al asociarse, es la sociedad" (Durkheim, 2002: 75-76). La sociedad es, pues, el único origen y la fuente de toda creencia moral. "Somos seres morales- escribe Durkheim- en la medida en que somos seres sociales (...). Todo lo que hay en nosotros de verdaderamente humano nos viene de la sociedad, todo lo que constituye nuestras conciencias de hombres nos viene de ella" (2002: 78 y 214-15).

La razón de todo ello es que en toda época y lugar es la sociedad la que ha hecho que los individuos se eleven por encima de su particularidad:

Una sociedad es a sus miembros- escribe Durkheim- lo que un dios es a sus fieles. Un dios es una potencia superior al hombre, que le manda y de quien depende. Y bien, la sociedad tiene, con respecto a cada uno de nosotros, la misma superioridad. La sociedad, igual que la divinidad, transciende infinitamente al individuo, en el espacio y en el tiempo (Durkheim, 2002: 213)

Ahora bien, aunque este es el carácter que universalmente tiene cualquier sociedad, lo que Durkheim se propone es crear una nueva moral tomando como base la sociedad industrial. En efecto, como ya no es posible regresar a un estadio social anterior, superado por la propia dinámica de la industrialización, esta es la única alternativa. Pero no por ello hay que aceptarla irremediablemente. La tarea que Durkheim se impone es, pues, reformar la sociedad industrial de acuerdo con sus propias necesidades, pero repudiando muchas de sus más nefastas consecuencias. Dicho de otro modo, de lo que se trata es de poner esas necesidades en relación con los principios morales emanados de la Revolución Francesa, que hasta ese momento habían sido sepultados bajo el más voraz egoísmo economicista. 
Más concretamente, lo que Durkheim así se propone es crear un orden social que armonice la ética del trabajo con el individualismo, la igualdad y la justicia social (Lukes, 1984: 155). Una sociedad que "sólo nos pide- escribe- ser afectuosos con nuestros semejantes y ser justos, cumplir bien nuestra misión, trabajar en forma que cada uno sea llamado a las funciones que mejor pueda llenar, y reciba el justo precio a sus esfuerzos" (Durkheim, 1995: 478).

Para llevar a cabo esta nueva misión la educación se antojaba imprescindible. Mediante ella, afirma Durkheim, el "ser egoísta y asocial" que es el niño al nacer, se convertirá en un ser moral (2002: 31). La educación estaba así destinada a arrancar ese egoísmo infantil despertando en los más jóvenes esa nueva conciencia moral que nacía del hermanamiento entre el productivismo industrial y los valores de la autonomía, la igualdad y la solidaridad. Una conciencia que eleve a la infancia por encima de sus particulares intereses; que le haga sentir y pensar que debe sacrificarse por algo que merece la pena. "No podremos instituir una educación laica- escribe Durkheim- si no podemos asignar al individuo un fin que lo trascienda, si no podemos dar algún objetivo a la necesidad de consagrarse y de sacrificarse que es la raíz de toda vida moral" (2002: 195).

Para emprender esta labor educativa la escuela estaba mejor preparada, según Durkheim, que la familia. Ésta última se inclina más al particularismo, mientras que la primera es más universal, sitúa a la infancia "en unas condiciones de edad y sociales sensiblemente análogas" (Durkheim, 2002: 177). Y universal es también la moral que allí deberá enseñarse. La escuela permite también recrear la vida comunitaria; es como si de una pequeña sociedad se tratase (Durkheim, 2002: 128 y 182). Habrá, pues, que utilizar todos los resortes de esta microsociedad para que todos los niños sientan e interioricen los principios de la nueva moral como algo superior a ellos, y que sin embargo también forma parte de ellos:

Como la vida escolar- escribe Durkheim- no es sino el germen de la vida social, como ésta no es sino la culminación y la continuación de aquélla, es imposible que los principales procedimientos mediante los que funciona una no se encuentren también en la otra (...) Cuanto mejor conozcamos la sociedad, mejor podremos percatarnos de lo que ocurre en ese microcosmos social que es la escuela (2002: 35$)$

La escuela pública se erigirá así en el nuevo santuario laico; en el lugar en el que la infancia habrá de socializase, impregnándose de la nueva moral por medios científicos y racionales.

La obra de la escuela, en el desarrollo moral del niño- afirma Durkheim-, puede y debe ser de la mayor importancia (...) si la familia puede despertar y consolidar los sentimientos domésticos necesarios para la moral e incluso, más en general, los que constituyen la base de las relaciones privadas más sen- 
cillas, no está constituida de manera que pueda formar al niño para la vida social (2002: 50$)$.

Debe ser, pues, la escuela quien realice esta tarea. Y debe realizarla por medio de la razón, alejándose de cualquier superstición. Hay que "hacer sentir al niño (la realidad de esta moral) sin recurrir a ningún intermediario mitológico" (Durkheim, 2002: 43). Porque, "si la moral es algo racional, si solo se ocupa de ideas y sentimientos que dependen de la razón, ¿por qué iba a ser necesario recurrir, para fijarla en los espíritus y caracteres, a procedimientos que escapan a la razón?" (Durkheim, 2002: 40).

La razón debe ser, pues, la vía a través de la cual se enseñe a todos los individuos en igualdad de condiciones. A través de la razón no sólo se enseñará la moral y todas las ciencias humanas que nos muestran las ventajas de la vida colectiva, sino también todas las demás ciencias que nos preparan para desempeñar una determinada función en algunas de las múltiples ocupaciones que ofrece la sociedad industrial. Los saberes que no respondan a algunas de estas funciones tendrán un carácter secundario, como por ejemplo el arte, que aleja al individuo de su realidad social transportándolo con determinadas ensoñaciones (Durkheim, 2002: 202-203).

No obstante, la razón no es suficiente para completar esta tarea. Se requiere algo más que haga sentir a los más jóvenes la importancia de lo que se les está diciendo. "Hace falta- escribe Durkheim- que el acto reclamado no nos resulte extraño, que podamos desearlo, que, de alguna manera, nos parezca bueno y digno de ser amado" (Durkheim, 2002: 211). Ahora bien, para ello es preciso sentir veneración y respeto por quienes lo invocan. Durkheim cree que esa invocación sólo puede venir del medio en el que el sujeto se socializa; de la misma sociedad que lo ha creado, proporcionándole una conciencia de los otros y de sí mismo. Pero, para que esta conciencia sea sentida como algo exterior e interior al mismo tiempo, debe hacer comprender al individuo que las razones por las que se sacrifica son también las suyas propias. La sociedad presenta precisamente esa doble cara, "en un caso es como el dios celoso y temido, el legislador severo que no permite que sus órdenes se transgredan; (y) en el otro, es la divinidad que socorre, a la que el creyente se sacrifica con alegría" (Durkheim, 2002: 94).

Por un lado, pues, la sociedad representa la autoridad, cuya expresión más concreta es el espíritu de disciplina. “¿Qué es la disciplina- señala Durkheim- sino la sociedad concebida como quien nos manda, quien dicta las órdenes, quien nos da sus leyes?" (2002: 94). Pero por el otro, estas leyes y estas órdenes, vinculadas a una reglamentación que limita los impulsos más egoístas de los individuos, también promueven y posibilitan su desarrollo autónomo y libre. La síntesis de todo 
ello es que "el individuo se somete a la sociedad, y esta sumisión es la condición de su liberación" (Durkheim, 2000: 96).

$\mathrm{Y}$ aunque en estas condiciones en algunas ocasiones el castigo se hace necesario, cuando se infringen los principios que protegen la libertad de cada individuo y de la colectividad escolar en su conjunto, su función no es otra que "reafirmar las conciencias a las que la violación de la regla ha podido, ha debido necesariamente turbar en su fe" (Durkheim, 2002: 139), restituyendo la creencia que el infractor había puesto en cuestión. Por ello, lejos de ser puramente punitivo, el castigo tiene en este caso un carácter excepcional y positivo.

$\mathrm{Al}$ docente corresponde en este contexto la responsabilidad de velar por la moral que el infractor ha pretendido cuestionar. Para tal misión ha de estar, como lo estaban los antiguos sacerdotes, investido de un cierto carácter sagrado, como sagrada es también la sociedad en representación de la cual habla a sus discípulos (Durkheim, 2002: 132).

A él corresponde, pues, enseñar el núcleo de la doctrina moral que reclaman las sociedades modernas. Una moral que exige poner la voluntad al servicio de una obra superior a ella misma, sin coartar por ello la libertad. Este es el mismo principio que debe animar la dinámica de la sociedad industrial. En ella también las ocupaciones laborales tienen que desempeñarse sin obstáculos que coarten la capacidad natural de los sujetos, dentro de una competición libre y justa con los demás, y al servicio de los intereses del conjunto de la colectividad. "Lo esencial- afirma Durkheim- es encontrar un fin para la actividad que esté en armonía con nuestras facultades y que nos permita realizar nuestra naturaleza" (2002: 69). "Cada unoescribe Durkheim- está entonces en armonía con su condición y no desea más que lo que puede legítimamente esperar" (Durkheim, 1995b: 267). En estas condiciones la conciencia de cada individuo coinicide planamente con la de la colectividad. El resultado de todo ello es una moral "libremente aceptada, y esta aceptación libre no es otra cosa- nos dice Durkheim- que una aceptación iluminada" (2002: 110). Iluminada, porque el individuo ha llegado al juicioso convencimiento de que su necesidad es la condición para su libertad.

Durkheim estableció así todo un proyecto educativo que conciliaba la intención de socializar con la de liberar (Dubet, 2006: 44). "El individuo se somete a la sociedad -escribió-, y esta sumisión es la condición de su liberación" (Durkheim, 2000: 96). La escuela desempeñaba en este contexto un papel fundamental, concienciando a cada individuo de su deber social, sin coartar para ello su particular inclinación natural (Durkheim, 2002: 110). Cada persona no desearía entonces sino lo que debiera desear (Lukes, 1984: 126). Esta plena armonización entre el individuo y la colectividad en una comunidad articulada alrededor del hecho laboral, permitiría, según Durkheim, construir una sociedad más justa y democrática, 
abierta a un futuro de progreso continuo. Para ello la educación era una tarea esencial. El auténtico santuario laico de la naciente sociedad industrial (Durán, 2008).

Esta intención de construir un programa educativo que integrase las necesidades de los individuos con las de la colectividad, en el marco de una sociedad democrática e industrial, coincidía en buena medida con la propuesta del filósofo y pedagogo norteamericano John Dewey. Aunque para ello adoptó una perspectiva más pedagógica que sociológica, en la que la infancia adquiría un especial prtagonismo.

\section{John Dewey: Democracia industrial, educación e infancia}

John Dewey (1859-1952) propuso un programa educativo que coincidía, en efecto, en muchos aspectos con el de Émile Durkheim. También él ejerció una enorme influencia política y social, sobre todo en América, a través del movimiento de la Escuela Nueva, que sedujo a muchos docentes (González Monteagudo, 2007: 15; Bowen, 1985 III: 529); sus ideas, basadas en la corriente filosófica del Pragmatismo ${ }^{33}$, inspiraron, asimismo, varias de las reformas educativas emprendidas en la primera mitad del siglo XX.

¿Cuáles eran los puntos esenciales de un pensamiento, que como el de Durkheim, contribuyó a cimentar el consenso educativo que permaneció vigente en Occidente hasta los años 70 de la pasada centuria?

$\mathrm{Al}$ igual que Durkheim, Dewey pretendía conciliar también los intereses del industrialismo con los principios y los valores de la sociedad democrática (Bowen, 1985: 531). "Con el cambio de una sociedad oligárquica a una democrática- escribió- es natural que adquiera importancia la significación de una educación que tiene como resultado la capacidad para abrirse un camino económicamente en el mundo" (Dewey, 1995: 107). Un camino para todos, porque una sociedad "verdaderamente democrática" - dijo- es aquella en la "que todos participan en el servicio útil y todos disfrutan de un ocio valioso" (Dewey, 1995: 219). Para cumplir con este cometido la escuela debía ser para Dewey, como también lo fuera para Durkheim, una verdadera comunidad social en miniatura:

Cuando la escuela- dijo- convierta y adiestre a cada niño de la sociedad como miembro de una pequeña comunidad, saturándole del espíritu de cooperación y proporcionándole el instrumento para su autonomía efectiva, entonces ten-

\footnotetext{
Más concretamente, Dewey, desarrolló una versión del pragmatismo denominada instrumentalismo; desde este punto de vista las ideas son entendidas como instrumentos para resolver aspectos más o menos problemáticos de la realidad (González Monteagudo, 2007: 19).
} 
dremos la garantía mejor de una sociedad más amplia, que sería también más noble, más amable y más armoniosa (Dewey, 1915: 48) ${ }^{34}$.

Su pedagogía tenía, sin embargo, un carácter mucho más práctico y experimental; "educar- afirmó- es una constante reorganización o reconstrucción de la experiencia" (Dewey, 1995: 73). Y estaba, además, mucho más centrada en la infancia. "La educación- escribió- debe empezar con un estudio profundo de las capacidades, intereses y hábitos del niño" (Dewey, 1908: 4). Capacidades e intereses que sólo se revelarían- pensaba- cuando "los esfuerzos del educador conecten con alguna actividad que el niño está ejercitando por iniciativa propia, independientemente de aquél". De lo contrario -sostenía- "la educación queda reducida a presión desde afuera" (Dewey, 1908: 2). Todo aprendizaje se produce de este modo, según Dewey, "cuando los niños están dedicados a hacer cosas y a discutir lo que surge en el curso de hacerlas" ${ }^{35}$ (1995: 138 y 233).

En este contexto experimental, vocacional y solidario ya no se precisaría, pues, de la acción directiva y autoritaria del maestro. "Creo- dijo- que la disciplina de la escuela debería proceder de la vida de la escuela como un todo, y no directamente del maestro" (Dewey, 1908: 7). Educar "no es un asunto de "contar" y ser contadoafirmó en otro lugar- sino un principio activo y constructivo" que tiene lugar en un ambiente "cooperativo" (Dewey, 1995: 44).

Como actividad orientada al niño, experimental, utilitaria y democrática, la educación se convertiría así en uno de los más eficaces instrumentos de progreso. "Creo- afirmó Dewey- que la educación es el método fundamental de progreso y reformas sociales" (1908: 13).

Su obra se vincula así con toda una tradición pedagógica que se remite directamente a Rousseau. Al igual que el filósofo Ginebrino, Dewey entendía la educación como una actividad que tenía que partir de los intereses naturales de la infancia; y como aquél consideraba, asimismo, que esta actividad se originaba y se desarrollaba a través de la propia experiencia práctica del que aprende, y no de la transmisión del docente. En este último sentido su teoría educativa se separaba abiertamente de la de Durkheim. En efecto, si para éste último educar suponía transmitir un determinado acerbo moral de una generación a la otra, aunque contando con la participación activa de quienes lo recibían; para Dewey se trataba de

$34 \quad$ La obra The School and Society fue traducida tempranamente en España por Francisco Barnes (Dewey, 1915). Aunque en dicha edición no se indica la fecha, en el Boletín de la Institución Libre de Enseñanza de 1915 aparece una referencia a dicha obra, señalando que próximamente aparecerá una traducción de la misma (Nubiola y Sierra, 2001).

35 En la escuela laboratorio que Dewey creó en 1896 proponía que los niños aprendiesen las distintas materias a partir de su propia experiencia práctica; una experiencia vinculada con las distintas ocupaciones (González Monteagudo, 2007: 29). 
un proceso fundamentalmente práctico articulado a partir de la propia experiencia de los que aprenden.

Por lo demás, tal como se señaló al comienzo de este epígrafe, Dewey y Durkheim coincidían en una misma voluntad de crear un programa educativo que integrase las necesidades de la sociedad industrial con los principios democráticos. Esta voluntad estaba en relación con la de las democracias industriales, cuyos gobiernos impulsarán en la inmediata postguerra el desarrollo de sistemas educativos para formar trabajadores capacitados y también buenos ciudadanos. Las obras de Durkheim y Dewey tuvieron una gran influencia en este proceso; el primero más en Europa, el segundo en América. Pero ambos contribuyeron sustancialmente a legitimar los planes educativos impulsados por los distintos gobiernos occidentales, que generaron un importante consenso en el periodo comprendido entre el final de la Segunda Guerra Mundial y los años setenta.

\section{Conclusión}

Hasta aquí hemos querido mostrar las principales etapas del desarrollo del discurso educativo moderno. Un discurso que conformará las concepciones acerca de la educación ampliamente compartidas en el mundo occidental, al menos hasta los años sesenta de la pasada centuria.

En su origen, el pensamiento educativo moderno todavía combinaba elementos tradicionales y modernos. Era moderna, en efecto, la creencia en la bondad y en la perfectibilidad de la naturaleza humana; y tradicional, sin embargo, el deseo de integrar a la infancia en el mundo que le precede, constituido por los valores de la civilidad Humanista y cortesana. El movimiento Humanista y el de la Contrarreforma, así como las ideas educativas de John Locke, representan los más claros ejemplos de todo lo ello. En suma, aunque se confiaba en la naturaleza humana, considerada bondadosa, perfectible y flexible; también se sospechaba de ella por su inclinación al mal, un mal que se creía que arrastraba por la mancha del pecado original. No obstante, y a pesar de todo ello, se consideraba también que la naturaleza infantil podía ser reconducida integrando gradualmente al sujeto en el mundo de la mano de los adultos.

Esta doble condición de la naturaleza humana, buena y mala al mismo tiempo, y la posibilidad de corregirla integrándola en el mundo, en este caso el cortés y civilizado, estaba enraizada, tal como se ha mostrado en otra parte de esta obra, en la tradición cristiana medieval, que a su vez la había recibido de la clásica, interpretándola según la visión cristiana del ser humano. 
Para toda esta tradición la cultura y la educación iban de la mano. Las personas cultas eran también las más educadas; los que más sabían, eran asimismo los más civilizados. Y para ser culto y civilizado había que empaparse de la tradición, siguiendo las enseñanzas de las personas adultas, que la conocían y la interpretaban. En este sentido, la enseñanza, cuyo principal agente es quien transmite sus contenidos, era más importante que el aprendizaje, mucho más centrado en el sujeto que aprende. La educación implicaba de este modo la integración en el mundo en el que adquirían sentido todo ese acervo de normas y de conocimientos recibidos. Desde este punto de vista, la instrucción contaba mucho menos, pues las capacidades y las habilidades que a ella iban asociadas eran de orden técnico, por lo que no daban la medida del ser humano educado.

En este contexto, todavía existía una firme jerarquía de las edades, considerando la adulta como la más perfecta, y por ello también la principal referencia para infantes y jóvenes. No obstante, dentro del programa educativo de la civilidad humanista, y también del Lockeano, comenzarán a crecer gradualmente la separación entre estas edades, a medida que se reprima en la infancia todos aquellos comportamientos y actitudes contrarios a los civilizados. En este escenario emergerá una pedagogía cada vez más centrada en esta edad, aunque por el momento la meta de la vida continuase siendo la integración final en el mundo adulto. No obstante, a medida que vaya progresando esta manera de pensar la educación más centrada en la infancia, se apelará cada vez más al sujeto infantil para despertar en él su conciencia civilizada; una conciencia tanto más firme cuanto más socializada estaba. Esta voluntad de educar a individuos cada vez más conscientes de sí mismos, y por ello también del papel social que tenían asignado, conllevaba la necesidad de reprimir y de liberar al mismo tiempo. Aunque por el momento, y ese momento todavía fue relativamente largo, la liberación estaba claramente supeditada a la integración.

La pedagogía de la Reforma introdujo en este sentido importantes cambios. En primer lugar, depositando una confianza todavía mayor en la naturaleza humana que, siendo "sabia, honesta y santa", podría llegar a "conocer, nombrar y entender cuanto encierra el mundo entero" (Comenius, 1976: 18-8). Una confianza que se extendía también al método, por medio del cual dicha naturaleza sería llevada a donde el educador se propusiese. En segundo lugar, induciendo una sospecha de la sociedad- sospecha que ya se había insinuado en la obra de Locke-, a la que se hacía responsable de corromper y desvirtuar aquella naturaleza humana prístina y clara. Una naturaleza, cuya realización ya no se vinculaba al mundo cortés y civilizado, tal como sucediera anteriormente, sino a aquél otro formado por las cosas de la naturaleza. Todo ello con el objetivo de procurar el mayor bienestar material para el ser humano en la tierra. 
Para alcanzar este fin, ya no será tan importante el sentido común; aquél sentido que ajusta la razón al mundo compartido por los seres humanos. Sino la mente racional del sujeto mismo; una mente que toma los datos con los que trabaja de la naturaleza física circundante, sirviéndose para ello de los sentidos. "Nada, pues, necesita el hombre tomar del exterior, sino que es preciso tan sólo desarrollar lo que encierra oculto en sí mismo (...). Sólo la luz de la razón es forma y regla suficiente para todas las cosas", dejó escrito Comenius, el principal representante de este pensamiento (1976: 12). Lo que los seres humanos tenían por tanto a partir de ahora en común, según este pensamiento, ya no era el mundo, sino una misma capacidad de pensar racionalmente (Arendt, 1998: 309). La consecuencia más inmediata de todo ello era que el ser humano adulto dejaba de ser la medida de todas las cosas, de las buenas y de las malas que había en el mundo. Esta medida la tenía ahora el sujeto racional, que todo lo puede, y que tiene un afán desmedido por comprender y transformar la naturaleza circundante en su propio beneficio.

En este contexto, se entenderá que el fin de la educación no consistirá en transmitir y recibir el acervo de comportamientos, actitudes y conocimientos considerados civilizados, a través de la convivencia con otros seres humanos, observando y tomando el ejemplo de los adultos. A partir de ahora, se considerará que el sujeto aprende experimentando con las cosas físicas de la naturaleza. Las palabras, por medio de las cuales se trasladaba el contenido de una determinada tradición de una generación a la otra, se pliegan ante las cosas, ya que se cree que aquellas ya no revelan la verdad del mundo, una verdad que sólo puede residir en la esencia que anida en las cosas de la naturaleza.

Desde este punto de vista, la educación se transforma en instrucción. Porque educar significa, en efecto, desarrollar una serie de capacidades y de habilidades a través de la propia acción práctica del que aprende. Sin necesidad de penetrar en la densidad humana del mundo. Para lo cual es menos importante la disciplina, que relaciona al sujeto con el mundo, que el autocontrol, a través del cual éste se somete a su propia voluntad.

La educación se convierte así en un proceso que deja de mirar al pasado para focalizar su atención en el presente del sujeto que aprende, un sujeto que orienta ese aprendizaje hacia un futuro, en relación con un proyecto de desarrollo personal y material casi sin límite.

La pedagogía reformista, cuyo máximo representante es Comenius, supuso así un gran avance en la construcción del pensamiento educativo moderno. Y aun así, este avance estaba limitado por la mentalidad religiosa que todavía la impregnaba. Una mentalidad que, a pesar de ser más individualista y menos vinculada a la tradición que la católica, todavía relacionaba al sujeto con el mundo de sus mayores. "La naturaleza nos da las semillas de la Ciencia, honestidad y religión, pero 
no proporciona las mismas Ciencia, Religión y Virtud- escribe Comenius-; éstas se adquieren rogando, aprendiendo y practicando" (1976: 20).

Esta vinculación entre el sujeto y el mundo desaparecerá por completo en el pensamiento rousseauniano. "Todo está bien al salir de las manos del autor de las cosas: todo degenera entre las manos del hombre", es la frase que resume rotundamente esta nueva perspectiva (Rousseau, 2002: 37). Se produce así el más firme rechazo de toda la tradición anterior, considerada fuente de múltiples errores y perversiones. El educador debará partir, pues, de la infancia misma, cuya naturaleza es inocente y buena, para guiarla, sin dirigirla, hacia donde ella tienda, sin otros obstáculos que no sean los que procedan de su misma naturaleza y del medio natural en el que ésta se desarrolla. Todo ello a través de la propia acción práctica del sujeto que aprende. La educación se transforma así en puro aprendizaje, pues toda transmisión es una intromisión en la mente inocente y clara de la infancia. Y adquiere también el carácter de instrucción, por cuanto supone la adquisición de una serie de habilidades por medio de la propia acción práctica de quien aprende. Acción que se expresa como trabajo, dando así satisfacción a todas las necesidades de la especie humana.

El pensamiento de Rousseau dejó una profunda huella en las distintas corrientes del socialismo y del anarquismo, así como del propio marxismo, cuya originalidad es desde el punto de vista educativo más bien escasa. Todas estas corrientes contribuyeron sustancialmente a la difusión de la pedagogía rousseauniana. Por lo demás, pusieron un énfasis todavía mayor que su maestro en la capacidad del trabajo para humanizar, capacitar y desarrollar a la humanidad en todas sus vertientes. E insistieron, asimismo, con gran energía, como antes lo había hecho el ginebrino, en la necesidad de acabar con la tradición heredada, fuente de todo tipo de injusticias y de calamidades, para fundar a partir de sus ruinas un mundo nuevo tomando como modelo la infancia, la edad que nada o poco tiene que ver con el pasado. Una infancia a la que consideraron asimismo como inocente y limpia, y llena de potencialidades. Y a la que únicamente había que orientar a donde ella tendiese, creando así una sociedad más justa y abierta a un futuro de progreso indefinido.

La herencia socialista y marxista fue recogida, tanto en Europa como en América, y reformulada en el contexto de las nuevas democracias industriales, entre finales del siglo XIX y la primera mitad del XX. Esta reformulación se debió, en el caso de Europa, al sociólogo francés Émile Durkheim, y en América al filósofo y pedagogo Norteamericano John Dewey.

Ambos autores crearon un programa educativo que trataba de integrar las necesidades de la sociedad industrial con los valores del individualismo, la igualdad y la justicia social, heredados de la Revolución Francesa. Actuando de este modo, 
cimentaron y legitimaron el programa de la escuela meritocrática republicana. Si bien Durkheim lo hizo desde una perspectiva sociológica, queriendo integrar el ideario revolucinario francés en el orden de las sociedades industriales, creando así un corpus moral en el que la escuela pública debía socializar a la juventud y a la infancia, por medio de la autoridad docente. El docente era quien, en efecto, investido de tal autoridad, debía inculcar a sus alumnos que este era el único camino para el progreso de cada uno y el de los demás. Dewey, sin embargo, se centró más en la infancia misma, creyendo, en consonancia con la tradición rousseauniana, que a partir de su fecunda naturaleza, y a través de un aprendizaje fundamentalmente práctico centrado en el hacer, podría alcanzar el mayor desarrollo personal y colectivo dentro de una sociedad democrática e industrial.

La obra de Durkheim y la de Dewey supusieron así la culminación del pensamiento educativo moderno, que era parte de un amplio proyecto civilizatorio. Mediante la interiorización de los valores asociados a dicho proyecto, los sujetos debían tomar conciencia de su propia individualidad, expresada a través de su integración activa en la sociedad democrática e industrial (Dubet, 2006: 47-48). Desde la perspectiva durkheimiana esto significaba que "el individuo se somete a la sociedad, y esta sumisión es la condición de su liberación" (2000: 96). Desde la de Dewey que "en la escuela ideal" se encuentra "la reconciliación de los ideales individualistas e institucionales" (1908: 13).

Esta intención, de armonizar los intereses individuales y los colectivos, fue asumida expresamente por los planes educativos implementados por las democracias industriales occidentales, con la intención de promover la democratización y el desarrollo económico, logrando así un mayor progreso individual y colectivo (Gauchet, 2002: 114 y ss; Reynaud, 1983: 118).

Justo en el preciso momento en el que este programa alcanzaba su mayor éxito, comenzaron a surgir, sobre todo a partir de los años setenta del pasado siglo, las primeras críticas que denunciaban su carácter disciplinario, oculto bajo su proclamada intención liberadora y democrática. De estas críticas surgieron respuestas que radicalizaron muchos de los principios contenidos en dicho programa, al tiempo que debilitaban los resortes institucionales en el que éste se apoyaba.

$\mathrm{Al}$ igual que los anteriores a los que criticaban, estos discursos penetraron también en los entornos educativos, conformando una nueva manera de pensar la educación que ha ejercido una notable influencia en este ámbito (Le Goff, 2002: 99 y ss; 1999: 71 y ss). Este pensamiento, que denunciaba el carácter incompleto y la condición autoritaria del proyecto educativo moderno, favoreció una creciente 
separación entre los sujetos y el sistema, un sistema que en otro tiempo parecía garantizarles su más plena autonomía y desarrollo ${ }^{36}$ (Dubet, 2006: 69).

No obstante, en este discurso se percibía también la huella de la modernidad en la que en otros aspectos se criticaba. Una huella que se manifestaba en la apelación a un sujeto considerado en sí mismo, en relación con su particular naturaleza y su singular psicología. Y que se advertía, asimismo, en la gran confianza depositada en el método, y en la mayor importancia que también se concedía al aprendizaje respecto de la enseñanza. Un aprendizaje basado en la propia experiencia práctica del que aprende, y enfocado sobre todo a aquellos saberes que el mercado considera útiles y prácticos.

El próximo capítulo estará consagrado a analizar la obra de los principales autores que produjeron, difundieron y popularizaron este discurso, que, como se dijo, ha ejercido una notable influencia en el ámbito educativo.

36 No cabe duda de que en este hecho influyeron también otras circunstancias, no sólo las ideológicas, en un contexto de creciente déficit de integración de los sistemas educativos, como se verá en los capítulos siguientes de esta obra. No obstante, estas críticas contribuyeron a deshacer el encanto que en otro tiempo la modernidad había proyectado sobe el ámbito educativo. 



\title{
CAPÍTULO II \\ LA MODERNIDAD CONTRA SÍ MISMA: LA CRÍTICA DEL PROGRAMA EDUCATIVO MODERNO
}

\begin{abstract}
Estas grandes fuerzas de la cultura moderna perisguen interminablemente la igualación: el anhelo por la personalidad autosuficiente que porta en sí el cosmos y cuyo aislamiento posee el gran consuelo de ser igual a todos los demás en su núcleo natural más profundo; y el anhelo por la incomparabilidad del ser-único y del ser-otro (Simmel, 2001: 422).
\end{abstract}

\section{INTRODUCCIÓN}

Las críticas al proyecto educativo moderno emergieron en los años sesenta y setenta de la pasada centuria. En algunos casos se expresaron como nuevas propuestas pedagógicas, integradas en la corriente de lo que se dio en llamar la pedagogía libertaria, y en otros como teorías sociológicas, pertenecientes al ámbito de la sociología crítica. Ambas perspectivas denunciaban la dominación oculta tras las proclamas liberadoras del programa educativo moderno, o su carácter incompleto por la imposibilidad de cumplir con sus promesas. Así, los valores y las normas que dicho programa elevaba como principios universales para la liberación de los sujetos, fueron considerados como parte esencial de un sistema de dominación que era necesario desvelar para mostrar su carácter más represivo. La integración armónica entre individualidad y sociabilidad; entre libertad y necesidad, que diera forma a aquel programa fue así cuestionada en busca de una individualidad y de una igualdad aún más auténticas (Dubet, 2006; Simmel, 2002: 103 y ss; 2001: 418 y ss), no contaminadas por las distorsiones que imponían las estructuras de la sociedad capitalista.

Todo este discurso ha dejado huella en las posteriores corrientes educativas, tanto liberales como progresistas, conformando una nueva mentalidad educativa que se ha erigido en dominante desde los años ochenta del pasado siglo (Le Goff, 2002: 101).

En este capítulo analizaremos los discursos de la sociología crítica y de la pedagogía libertaria a partir de los principales autores que los produjeron y los po- 
pularizaron. Siguiendo este criterio, se han elegido dos autores en el campo de la sociología crítica, Michel Foucault y Pierre Bourdieu; y otros dos en el de la pedagogía libertaria, Alexander S. Neill e Ivan Illich. Mostraremos cómo todos ellos, a pesar de sus importantes diferencias, contribuyeron a crear una imagen de las instituciones y de los sujetos cada vez más divergente (Dubet, 2006: 44). En efecto, el programa socializador que el proyecto educativo moderno había promovido y garantizado como parte de las promesas de liberación de los sujetos, fue percibido ante todo como una estructura de dominación que los oprimía. Por lo que dicha liberación sólo podría alcanzarse fuera del orden institucional. Al actuar así, promovieron una visión de la relación escolar mucho más subjetiva y centrada en el presente. Este punto de vista, que ha contribuido a deslegitimar el ámbito institucional, reificando los aspectos más subjetivos de una relación escolar que se actualiza permanentemente, ha influido también en los discursos educativos de nuestra época. En efecto, estos discursos han incorporado buena parte de las críticas dirigidas al programa educativo moderno por la sociología crítica y la pedagogía libertaria, emergiendo así una suerte de nuevo espíritu educativo, que a semejanza de aquel otro que impera en el ámbito laboral y productivo (Boltanski y Chiapello, 2002), actuaría legitimando la relación escolar en un contexto de crisis.

En lo que sigue, analizaremos el pensamiento de cada uno de los autores pertenecientes al ámbito de la pedagogía libertaría y de la sociología crítica, con la intención de observar cómo a partir de visones bien diferentes de la relación educativa ha emergido un discurso profundamente crítico con el programa educativo moderno. Finalizaremos este capítulo mostrando de qué modo este discurso ha influido en el pensamiento educativo actual.

\subsection{SUMMERHILL: LA EDUCACIÓN CENTRADA EN LA INFANCIA}

El programa educativo que Alexander S. Neill (1883-1973) puso en práctica en la escuela inglesa de Summerhill se inscribe en los discursos críticos y libertarios sobre la educación. Dicho programa alcanzó una gran popularidad. De hecho, de su libro más conocido, que relata su experiencia educativa en dicha escuela (publicado por primera vez en América en 1960 y más tarde, en 1962, en Inglaterra), se vendieron más de dos millones de ejemplares en varias lenguas (Puig, 2009: 158; Le Goff, 2002: 100; Hobson, 2001). Tal éxito de ventas parece demostrar que muchas de las ideas que en él se exponían, y que ejercieron una importante influencia tanto en las teorías como en las prácticas pedagógicas (Puig, 2009: 166; Le Goff, 1999: 77), no eran contrarias a las actitudes sociales de la época (Sommerville, 1982: 219).

Neill era un psiquiatra y psicólogo inglés dedicado a atender a los niños menos integrados (Le Goff, 1999: 368). Sus concepciones educativas estaban inspira- 
das en la psicología en general, y en Sigmund Freud y Wihelm Reich en particular (Puig: 2009: 155 y ss; Hobson, 2001: 14-18). "Creo firmemente- escribió en referencia al primero- que los descubrimientos de Freud tendrán más influencia en la evolución de la humanidad que cualquier otro descubrimiento de los diez últimos siglos" (citado en Fromm: Prólogo Neill, 1997; Saffange, 1994: 5). Neill se inspiró, asimismo, en la tradición pedagógica occidental de raíz rousseauniana (Puig, 2009: 153 y ss; Hobson, 2001).

Puso sus ideas en práctica en la escuela de Summerhill, que fundó en 1924 junto a su primera esposa, en el pueblo inglés de Lymes Regis. Más tarde, en 1927, trasladó la escuela a la aldea de Leiston, en Suffolk, una zona rural de la región de Londres (Hobson, 2001). A dicha escuela acudían chicos y chicas de entre cinco y dieciséis años con actitudes difíciles, la mayoría provenientes de familias acomodadas, sobre todo inglesas, aunque también de EE. UU y de otros países de Europa, principalmente Noruega, Suecia y Dinamarca (Le Goff, 1999: 368; Neill, 1997: 19-87).

Su libro más conocido (Neill, 1997), en el que relata su experiencia en la escuela de Summerhill, era un verdadero ataque a la educación tradicional (Saffange, 1994), todavía imperante en los años 60 en Gran Bretaña y en los países occidentales. Para Neill este tipo de educación era la fuente del odio, del fracaso y de la infelicidad (Le Goff, 1999: 368; Sommerville, 1982: 219). Por ello, propuso como alternativa a este tipo de educación otra mucho más centrada en la infancia. "Cuando mi primera esposa y yo establecimos la escuela- escribió-, teníamos una idea predominante: hacer que la escuela se acomode al niño, y no hacer que el niño se acomode a la escuela" (Neill, 1997: 20, comillas del original).

La intención de Neill era crear un ambiente educativo en el que se instruyese a la infancia en la felicidad: "Este libro -dijo- es la historia de un lugar- Summerhill- donde se cura la infelicidad de los niños y, cosa más importante todavía- dijo-, donde se cría a los niños en la felicidad" (1997: 17).

Para tal fin, consideró necesario otorgar a la infancia el verdadero protagonismo de la acción educativa. "Todo es cuestión de fe en los niños", afirmó (Neill, 1997: 108). Rechazó por ello enérgicamente toda intervención externa que perturbase la voluntad infantil para dirigirla en el sentido deseado por los adultos.

La función del niño -escribió- es vivir su propia vida, no la que sus impacientes padres desean para él, ni la que esté de acuerdo con el propósito del educador (...). Todas estas interferencias y guías por parte de los adultos sólo producen una generación de autómatas (Neill, 1997: 26).

El niño era, en efecto, según él pensaba, "un ser bueno...sensato y realista", por lo que "si se le dejaba entregado a sí mismo, sin sugestiones de ninguna clase 
por parte de los adultos, se desarrollaría hasta donde fuese capaz de desarrollarse" (Neill, 1997: 20). Neill tenía de este modo "la firme convicción", de acuerdo con la tradición educativa anterior, sobre todo la que iba de Rousseau a Dewey, "de que el niño era un ser bueno" (1997: 20), y que, por ello, era necesario devolverlo a su propia naturaleza, que se manifestaba ante todo en su actividad práctica, para lograr así su mayor bienestar y felicidad.

De acuerdo con este ideario, consideró imprescindible acabar con aquel tipo de enseñanza ocupada únicamente en trasladar el mundo de los adultos a la infancia. “Toda opinión que se le impone a un niño- escribió- es un pecado contra él. Un niño no es un adulto pequeño y, posiblemente, no puede tomar el punto de vista del adulto" (Neill, 1997: 210).

El acervo moral y los conocimientos que los adultos transmitían a la infancia no hacían otra cosa, según Neill, que reprimir y perturbar el carácter infantil (Hobson, 2001; Saffange, 1994). No cabía, pues, otra alternativa que acabar con toda esa herencia académica y moral. "Veo -escribió- que cuando hago pedazos la instrucción moral que ha recibido un niño, éste se convierte en un niño bueno" (1997: 210-207). Una vez derribada esta herencia, sólo quedaba entonces fijar la atención en la naturaleza. “Toda la idea de Summerhill -afirmó- es la liberación: permitirle al niño que viva sus intereses naturales” (Neill, 1997: 105).

Para ello, era completamente innecesario recurrir a la autoridad, de cualquier clase que esta fuese.

Creo- sostuvo- que es un error imponer algo por autoridad. El niño no debiera hacer algo hasta que se forme la opinión- su opinión propia- de que debe hacerlo (...), la maldición de la humanidad es la coacción externa, ya venga del papa, o del Estado, o del maestro, o del padre (Neill, 1997: 105).

En lugar de alguien con autoridad, bastará, en caso necesario, con la orientación del terapeuta (Neill, 1997: 44 y ss). Del responsable de llevar a cada individuo al encuentro con su propia naturaleza. Aunque lo ideal es que este encuentro tenga lugar libremente, por iniciativa del propio sujeto. El objetivo final es alcanzar la autodisciplina, aquel estado en el que el individuo se somete enteramente a su propia autoconciencia, teniendo como único límite la libertad de los demás (Neill, 1997: $105,238,239)$.

La acción educativa se transforma así en una verdadera relación psicológica presidida por la libertad y la igualdad entre jóvenes y adultos. "Para los niños- escribió Neill-, yo no soy una autoridad a la que tengan que temer. Soy un igual" (1997: 23). En Summerhill imperaban por ello los mismos principios democráticos que regían en la vida pública (Sommerville, 1982: 220). Si la libertad era, en 
efecto, el fin que se perseguía, ésta no podría lograrse- pensaba Neill- "si los niños no se sienten completamente libres para gobernar su propia vida social" (1997: 58). La escuela debía administrarse de este modo autónomamente, sometiéndose cada uno de sus alumnos, enteramente, a la presión democrática del grupo (Le Goff, 1999: 373; Saffange, 1994: 2). "Summerhill -dijo Neill en este sentido- es una escuela autónoma de forma democrática. Todo lo relacionado con la vida social o de grupo...se decide por votación en las asambleas generales escolares (...) mi voto pesa lo mismo que el de un niño de siete años" (1997: 52). Al ingresar en esta escuela cada individuo entraba así a formar parte- consideraba Neill- de una vida comunitaria verdaderamente igualitaria y justa.

El ideario educativo de Neill se basaba en la oposición, de raíz rousseauniana, entre la infancia y el mundo (Puig, 2009: 153 y ss). La sociedad era, en efecto, según él decía, la causante de todos los males que aquel pudiese padecer o haber padecido. "Todos los niños malos que yo he manejado -afirmó- fueron casos de una primera educación desorientada y de una primera enseñanza equivocada" (Neill, 1997: 205). Por ello -decía- "cuando los intereses individuales del niño y sus intereses sociales choquen debe darse preferencia a los intereses individuales" (Neill, 1997: 105). Se trataba, ante todo, de propiciar el regreso de la infancia a su propia naturaleza, donde residía su verdadera esencia. El fin de este encuentro entre el individuo y su ser natural era la búsqueda de una autenticidad única, en la que aquél hallase el goce y la felicidad. El educador se transformaba así en terapeuta. En la persona encargada de llevar a la infancia a este gozoso y feliz autoconocimiento; por oposición al maestro, empeñado únicamente en trasladar su propia concepción del mundo a esta edad.

El programa educativo de Neill era, desde este punto de vista, ciertamente contradictorio. Se proponía educar sin transmitir apenas valores y conocimientos (Saffange, 1994: 4). "No creemos que importe mucho la enseñanza en sí misma”, dijo (Neill, 1997: 20). De modo semejante a Rousseau, consideraba que todas aquellas conductas que la buena sociedad aprobaba eran falsas e hipócritas. "Lo que puede llamarse etiqueta -escribió- es algo "exterior" y "vacío" (...) el progreso de la civilización consiste en librar al mundo de vergüenzas y de apariencias" (Neill, 1997: 164-169). Parecida opinión tenía el filósofo ginebrino. "Las sospechas, la desconfianza, los temores, la frialdad, la reserva, el odio y la traición- dijose esconderán sin cesar bajo ese velo uniforme y pérfido de las buenas maneras, bajo esa urbanidad tan celebrada que debemos a las luces de nuestro siglo" (citado en Starobinski, 1983: 13).

Ambos querían, en efecto, que el ser y el parecer confluyesen. Esta confluencia se lograría, según Neill, cuando la meta de la educación fuese la felicidad. Cuando los sentimientos y las emociones imperasen sobre los conocimientos (Puig, 2009: 
161; Hobson, 2001: 15) ¿Para qué se precisarían entonces tantos saberes y tantas normas morales, sino era para perturbar lo que de verdad importa, sentir en lo más profundo del ser la satisfacción plena de esta comunión con uno mismo?

Cuando hablo para estudiantes- afirmó Neill- me impresiona con frecuencia el grado de inmadurez de aquellos muchachos y muchachas atiborrados de conocimientos inútiles. Saben muchas cosas...pero en sus puntos de vista sobre la vida son niños. Porque se les ha enseñado a saber, pero no se les ha dejado sentir (...) Les falta algo; el factor emocional, la facultad de subordinar el pensar al sentir (...) Y así va el sistema, atenido únicamente a normas de aprendizaje en libros, alejando la cabeza del corazón (Neill, 1997: 37-38, comillas del autor).

Aparece de nuevo en estas palabras de Neill la profunda huella rousseauniana. En efecto, tanto para él como para el ginebrino la verdad había que encontrarla en lo más profundo del corazón humano, aunque no en las palabras, que no eran más que la muestra de la hipocresía civilizada. El objetivo era volver, pues, al gozoso encuentro del sujeto consigo mismo. "La religión nueva- escribió- se basará en el conocimiento del yo y en su aceptación” (Neill, 1997: 204). Para ello, encontró una rica fuente de inspiración en las ideas Freudianas (Neill, 1997: 85-238). Porque, en efecto, la teoría de Freud alimentaba la creencia del individuo moderno en el conocimiento del propio yo como camino hacia la felicidad. La intención era salvar al sujeto del mundo que lo oprimía, proyectándolo sobre su propia interioridad, para que de ella brotase una nueva conciencia más feliz y libre (Illouz, 2010: 41 y ss). "Permitiremos a los niños vivir- proclamó Neill en este sentido- de acuerdo con sus impulsos profundos" (1997: 238).

Esta confianza casi absoluta en el propio yo, y la desvalorización del mundo de la que fue acompañada, desembocó en el cuestionamiento de la institución escolar en varios sentidos. Como sede de la autoridad legítima, ya que dicha autoridad se identificada con la represión de los sujetos. Como fuente de transmisión de conocimientos, pues éstos coartaban la libertad, impidiendo la realización de cada individuo a partir de su propia naturaleza. Y también como realidad vinculada al pasado o al futuro, puesto que educar significaba ante todo potenciar libremente, sin imposiciones externas, lo que cada individuo era en el presente, sin mirar ni al pasado ni al futuro.

En sentido contrario, este discurso favoreció la autonomía del sujeto escolar, transformado en el referente casi absoluto de la acción educativa; un sujeto que aprende mediante su propia acción práctica, y a partir de sus particulares intereses.

En una dirección parecida actuó el pensamiento de Ivan Illich, verdadero apóstol de la sociedad desescolarizada. A él estará dedicado el próximo epígrafe. 


\subsection{IVAN ILLICH: EDUCACIÓN SIN ESCOLARIZACIÓN}

Ivan Illich (1926-2002) se sitúa también en el ámbito de la pedagogía libertaria. Popularizó a comienzos de los años 70, en su obra más conocida, La desescolarización de la sociedad, publicada originalmente en 1970 (Illich, 1973), la idea de una sociedad sin escuela. Dicha obra ejerció una gran influencia, sobre todo en las corrientes educativas más progresistas (Igelmo, 2012: 35-36; Tort, 2009: 280; Heath y Potter, 2005: 206; Le Goff, 1999: 77).

Su pensamiento era profundamente antiinstitucional (Tort, 2009: 280; Heath y Potter, 2005: 204-205; Le Goff, 1999: 362). Consideraba, en efecto, que la mayor parte de las instituciones modernas eran entramados burocráticos que servían únicamente a intereses manipulativos y coercitivos, destinados a reprimir y a transformar negativamente la psique humana (Illich, 1973: 74-75). "La institucionalización de los valores- dijo- conduce inevitablemente a la contaminación física, a la polarización social y a la impotencia psicológica" (Illich, 1973: 11). Creía, por ello, que la auténtica libertad y la verdadera igualdad sólo se lograrían fuera del orden institucional. Un orden empeñado únicamente en reprimir la autonomía individual, sin contribuir en nada a la emancipación y a la justicia social (Le Goff, 1999: 364). En este sentido Illich no era ajeno al ambiente de crítica institucional característico de la segunda mitad de los años 60 y la primera mitad de los 70. "Un periodo- escribió- de resistencia creciente...a todas las formas de instrucción planificadas institucionalmente" (Illich, 1973: 94).

La escuela representaba para Illich, precisamente, uno de los ejemplos más acabados de esta planificación institucional manipulativa y coercitiva, destinada a proporcionar el tipo de individuos que requería la sociedad industrial. "Los niños se convierten- afirmó- en un recurso natural que han de moldear las escuelas para luego alimentar la máquina industrial" (Illich, 1973: 90).

La universalización de la escuela era pues para él, no ya un instrumento de democratización, sino, por el contrario, la mayor empresa productora de desigualdad y de represión (Tort, 2009: 284). En su opinión, detrás de esta pretensión universalizadora estaba la intención, legitimada por la propia institución escolar, de controlar las vidas de las personas, orientándolas en la dirección que la propia institución deseaba (Illich, 1973: 13).

Los sistemas educativos no eran, pues, para Illich más que instituciones al servicio de "una sociedad de consumo orientada hacia el crecimiento, tanto para ricos como para pobres" (Illich, 1973: 50). Instituciones que empleaban toda una serie de saberes destinados a satisfacer los intereses de dicha sociedad (Le Goff, 1999: 363). 
Muchos de estos saberes integraban lo que él denominó el "curriculum oculto". Dicho curriculum- escribió- "inculca en el alumno el mito de que la mayor producción proporcionará una vida mejor (...) Crea el hábito de consumo de servicios y de producción enajenante, la tolerancia ante la dependencia institucional, y el reconocimiento de los escalafones institucionales" (Illich, 1973: 99).

En todas las sociedades, sean estas fascistas, democráticas o socialistas, el sistema escolar desempeña, según Illich, estas mismas funciones, que adquieren por ello un carácter mítico (1973: 99-100). La escuela se habría convertido así en la auténtica "religión del proletariado modernizado". Ya que "ninguna institución podría ocultar mejor a sus participantes la profunda discrepancia entre los principios sociales y la realidad social en el mundo de hoy". Una religión que, amparada por "la sabiduría institucional", inviste al profesor de la autoridad necesaria para el desempeño de su función "en un recinto sagrado" (Illich, 1973: 22, 47 y 62). "La escalada de las escuelas" era por ello para Illich "tan destructiva como la de las armas" (Illich, 1973: 21).

¿Por qué tendrían, entonces, -dijo- que seguir teniendo las escuelas el monopolio de la enseñanza? Esta función podría ser desempeñada por muchas otras instituciones y grupos sociales. De hecho, esto es lo que realmente sucede, ya que "la mayoría de las personas adquieren- según Illich- la mayor parte de su conocimiento fuera de la escuela". Era preciso, pues, impulsar la completa desescolarización de la sociedad. Paso previo "fundamental para cualquier movimiento de liberación del hombre" (Illich, 1973: 25 y 66).

Para ello habría que crear, completamente al margen de la institución escolar, un nuevo modelo de educación, abierto a la creatividad y a la experimentación personal, que atendiese a los intereses y a las necesidades de cada individuo ${ }^{37}$ (Le Goff, 1999: 365). La educación se transformaría así en un espacio de encuentro entre personas animadas por intereses semejantes. Se convertiría- afirma Illich- "en una red o servicio que daría a cada hombre la misma oportunidad de compartir sus intereses actuales con otros motivados por iguales cuestiones" (1973: 33).

Para atender a este fin, no harían falta ya profesores que transmitiesen el conocimiento heredado; ni tampoco alumnos dispuestos a recibirlo. Ni unos ni otros tendrían ya una posición reconocida institucionalmente para desempeñar tales funciones. "Nuestras actuales instituciones educacionales- escribió Illich- están al servicio de las metas del profesor. Las estructuras de relación que necesitamos-

A comienzos de los años 60 Ivan Illich fundó en Cuernavaca (México) el Centro de Información Intercultural, llamado más tarde Centro Intercultural de Documentación (CIDOC), destinado a reflexionar y a concebir nuevos métodos de enseñanza (Tort, 2009: 279; Gabbard y Stuchul, 2001: 184). 
afirmó- son las que permitan a cada hombre definirse él mismo aprendiendo y contribuyendo al aprendizaje de otros" (1973: 96).

En vez de profesores, pues, líderes. Sujetos que inicien a los demás en los caminos que ellos ya han recorrido. Y cuya condición se deriva de su capacidad innovadora y creativa, lo que los convierte en "modelos de habilidades, administradores de redes o especialistas en orientación" (Illich, 1973: 132). La cultura y el conocimiento se conformarían así a partir de esta red de relaciones horizontales, creada a través del libre encuentro entre personas con intereses semejantes, y en las que nadie estaría en mejor posición que otro para imponer sus propios criterios (Illich, 1973: 120 y ss).

Illich establece así una hipotética situación de completa libertad e igualdad, en la que las oportunidades de acceso y de participación en esta red de conocimientos serían las mismas para todos los que en ella participasen. Si bien, el conocimiento al que se refiere se vincula fundamentalmente a competencias y habilidades (Illich, 1973: 115-116). Es decir, a actividades que se basan más en el hacer que en escuchar y leer; más en aprender que en enseñar. Y que por ello tienen que ver más con la instrucción que con la asimilación de un determinado saber heredado. Requieren, pues, para su desarrollo, de la participación activa del sujeto que aprende a través de su propia acción práctica, sin que sea preciso contar con alguien que trasnsmita un saber heredado.

No obstante, siempre cabría la posibilidad de que estas redes del saber fuesen controladas por distintos grupos dispuestos a crear sus propios monopolios del conocimiento (Tort, 2009: 293). Para evitar esta situación, Illich plantea la creación de ciertas instancias de control. Si bien dichas instancias también podrían convertirse en nuevas instituciones dispuestas a legitimar unos saberes en detrimento de otros. Y aun cuando esto no ocurriese, porque la igualdad de acceso a las redes fuese mayor, todavía podrían ser éstas dominadas por determinadas corrientes de opinión.

En cualquier caso, desde una perspectiva como esta, la relación educativa se transformaría en una densa red de servidores y de clientes animados por sus particulares intereses, lo único que verdaderamente tendrían en común. Ya no se trataría entonces de responder a la pregunta “¿qué debiera aprender alguien?", sino a la de " ¿con qué tipo de cosas y personas podrían querer ponerse en contacto los que buscan aprender a fin de aprender?" (Illich, 1973: 103). En este contexto, la acción educativa se definiría más por el interés de los consumidores que por su contenido (Le Goff, 1999: 365-366). La educación se convertiría así en un servicio vinculado a las necesidades vitales que satisface, a saber, producir cultura en una especie de mercado del conocimiento (Illich, 1973: 111). El valor de dicha cultura estaría supeditado, no tanto a la utilidad que procura a quienes la consumen, sino a su 
mera potencialidad para ser intercambiada en el seno de dicho mercado. Es decir, a su capacidad para convertirse en valor de cambio. Por lo que su perdurabilidad dependería de su mera funcionalidad (Arendt, 2003a: 318-319). Fuera de este contexto, ninguna cultura tendría más valor que otra.

La crítica institucional de Illich, con su acento en la desescolarización de la sociedad, derivó de este modo en un planteamiento en el que nada parecía elevarse por encima de los intereses de los individuos, quienes, reunidos en el espacio conformado por esa red del conocimiento por él imaginada, dictarían lo qué es interesante enseñar y aprender en cada momento.

Esta visión de la escuela como una institución esencialmente dominante y opresora, fue compartida también por otros autores procedentes de una tradición intelectual y académica completamente alejada de la pedagogía libertaria. Desde este punto de vista, resulta especialmente relevante la obra de Michel Foucault y de Pierre Bourdieu, cuya contribución a la mentalidad educativa actual ha sido también enorme.

\subsection{FOUCAULT: PODER, NORMALIZACIÓN, SUJETO}

La obra de Foucault (1926-1984) representa, en efecto, un esfuerzo intelectual alejado totalmente del carácter pedagógico de las propuestas educativas de Neill e Illich. Sin embargo, coincide con ellos, tal como se ha señalado anteriormente, en una misma visión crítica de las instituciones modernas, de las que sólo contempla, al igual que aquellos autores, su carácter represivo y manipulador.

Su teoría social ha ejercido también una importante influencia intelectual en la sociología crítica de la educación (Urraco-Solanilla, 2013: 154-165; Ball, 2001b: 5). El mismo Foucault no era ajeno a esta voluntad de influir cuando señalaba en su texto fundamental sobre educación, "Vigilar y castigar", publicado originalmente en 1975, que este libro "serviría de base para distintos estudios sobre la normalización y el poder del saber en la sociedad moderna" (Ball, 2001b: 9). Dicha influencia se ha dejado sentir particularmente, claro está, en Francia, pero también en España (Varela-Álvarez Uría, 1991) ${ }^{38}$. En Inglaterra esta obra fue recibida, sin embargo, más tardíamente, en los años noventa de la pasada centuria (Castilla, 1999b), siendo quizás la más citada de entre su extensa producción científica (Hoskin, 2001: 33).

El pensamiento de Foucault estuvo también vinculado a los movimientos sociales y culturales del mayo del 68 , con sus críticas al poder y a las instituciones disciplinarias emanadas de la modernidad (Dubet, 2006: 43; Habermas, 1993: 308-

38 En el caso de España, cabe destacar las imprescindibles aportaciones que ha hecho Julia Varela al análisis de la genealogía de la escuela, desde una perspectiva foucaultiana (Varela-Álvarez Uría, 1991). 
309). "De no ser por mayo del 68- afirmó en una ocasión-, nunca habría llegado a hacer las cosas que hoy me ocupan (...) El clima de mayo del 68 fue decisivo para mí en estos aspectos" (Citado en Pardo, 2000: 28-29). De hecho, sus ideas estarán presentes en todo este ambiente cultural, que dejará una profunda huella en la generación que lo protagonizó.

La obra de Foucault representa una de las más importantes contribuciones al análisis de las sociedades modernas. Se impuso, en efecto, la enorme tarea de analizar y de comprender, a través de una profunda exploración genealógica, los mecanismos de poder inherentes al orden social moderno. Un orden tejido, en su opinión, por una densa red de instrumentos disciplinarios, vinculados a organismos institucionales que recurren a diferentes discursos, saberes formalizados, técnicas y prácticas para imponerse. Este entramado institucional constituía lo que él denominó una "microfísica del poder" (Foucault, 1999: 212). "Toda una serie de poderes cada vez más firmes, microscópicos, que se ejercen sobre los individuos en sus comportamientos cotidianos y hasta en sus propios cuerpos" (Citado en Álvarez-Uría, 2000: 100). Poderes, que a través de la "inspección jerárquica", la "sanción normalizadora" y el "examen", los normalizan y los constituyen, al someterlos a los distintos órdenes disciplinarios (Foucault, 1999: 256).

El campo educativo era para él uno de los más claros exponentes de esta normalización disciplinaria, característica de la modernidad (Foucault, 1999: 211 y ss). De hecho, acaso sea en este ámbito en el que más han proliferado los análisis foucaultianos (Castilla, 1999b). Uno de los conceptos clave, que inspira a casi todos ellos, es el de control social (Martín Criado, 2003: 18). Un control que se relaciona directamente con la educación, una de las instituciones por excelencia que la modernidad ha empleado para extender todos sus instrumentos disciplinarios vinculados al poder-saber (Varela, 2001). De este control disciplinario- escribe Foucault- "ha nacido el hombre del humanismo moderno" (Foucault, 1999: 215). El hombre que el pensamiento educativo occidental había puesto como modelo civilizatorio, y en el que Foucault no quiere ver más que el producto de los poderes que lo han constituido. Poderes que no harían otra cosa que normalizar y construir a los sujetos, objetivándolos e individualizándolos a través de una compleja maquinaria de instrumentos disciplinarios. Al servicio de ella los profesionales de la educación y los distintos saberes escolares. Sus productos, los alumnos, segmentados y objetivados; separados unos de otros y de los adultos, por su clase de edad; por una condición inferior que los convierte en aprendices (Foucault, 1999: 239 y ss).

El poder se eleva así a concepto explicativo central en la teoría foucaultiana ${ }^{39}$ (Habermas, 1993: 304). Todos sus análisis caen bajo su influencia, de tal modo que

\footnotetext{
39 No obstante, Foucault afirmó que su obra no estaba orientada al estudio del poder, sino al del sujeto: "Mi objetivo -escribió- no ha sido analizar los fenómenos del poder ni sentar las bases de
} 
cualquier acto institucional acaba siendo percibido como un producto de dicho poder, y como tal perturbador de la libertad de los sujetos (Martín Criado, 2003: 19, Castilla, 1999a: 370). Aun cuando estos actos proclamen su intención racional y emancipadora, Foucault proyecta sobre ellos una actitud de sospecha, viendo en tales proclamas una intención fundamentalmente controladora y normalizadora: "las Luces, que han descubierto las libertades, inventaron también las disciplinas", señaló en este sentido (Foucault, 1999: 322). Su obra tiene por ello dificultades para salir del círculo del poder que él mismo trazó. En efecto, cualquier acción social, en cuanto cristaliza institucionalmente, se transforma en una nueva forma de poder. Siguiendo este mismo principio, todo saber amparado institucionalmente, acaba vinculándose con formas de poder y, por tanto, su validez se remite a los estrechos ámbitos de los mecanismos institucionales que lo han producido (Habermas, 1993: 336).

Toda esta crítica acaba por cuestionar los dos polos sobre los que se asentaba el proyecto educativo moderno; a saber, la libertad y la autonomía, por un lado; la institucionalización, destinada a garantizar esa libertad proclamada, por el otro. Esos dos polos constituían al individuo moderno, cuya subjetividad era el producto de un proceso de socialización que reprimía, pero que también conformaba una conciencia individual más autónoma e independiente (Dubet, 2006: 44). Foucault retiene de esa relación únicamente la coerción institucional, sin mencionar la intención emancipadora a la que aquella, en ocasiones, iba asociada. La conciencia individual no sería así para él más que la expresión de una voluntad de poder que objetiva e individualiza a los sujetos, introduciéndolos en su propio régimen disciplinario (Habermas, 1993: 349). "El que está sometido a un campo de visibilidad, y que lo sabe- afirmó-, reproduce por su cuenta las coacciones del poder" (Foucault, 1999: 296). Desde este punto de vista, son cuestionados todos los saberes que emanan de una determinada tradición, y en particular la moderna ilustrada, porque serían la expresión de una concreta voluntad de poder. Como también debe ser cuestionada la autoridad que los encarna.

Aunque este cuestionamiento no respondía a un planteamiento normativo, al que Foucault renunció explícitamente ${ }^{40}$, sus críticas al orden social moderno parecen

tal análisis. He pretendido más bien elaborar una historia de los diferentes modos de subjetivación del ser humano en nuestra cultura" (Foucault, 1986: 25). Y, sin embargo, todos sus textos son un intento de demostrar que este sujeto se construye a través de discursos y de prácticas disciplinarias vinculados a mecanismos de poder arraigados institucionalmente. Así lo reconoció explícitamente: "Es cierto- dijo- que me he visto obligado a interesarme de cerca por la cuestión del poder" (Foucault, 1986: 26).

40 No en vano, Foucault dejó claro que él no quería hacer "la historia de las soluciones", y que por esa razón no aceptaba el término de alternativa. "Me gustaría- dijo- hacer la genealogía de los problemas, de las problematizaciones” (citado en Álvarez-Uría, 2000: 102). 
pensadas desde una hipotética comunitas libre de toda clase de poderes y de controles, integrada e igualitaria, en la que la diversidad de conciencias pudiera manifestarse sin ningún tipo de mediaciones. De hecho, contempló las formas de resistencia frente a los distintos tipos de poderes como medios de "afirmar el derecho a la diferencia", y como modos de "enfrentarse a todo lo que pueda aislar al individuo, separarlo de los otros, desgajarlo de la vida comunitaria" (Foucault, 1986: 30) ${ }^{41}$.

No obstante, ¿no producen también estas mismas relaciones de poder, arraigadas institucionalmente, confianzas y seguridades, que son otras tantas fuentes de libertad? (Arendt, 1999: 106). Dicho de otro modo, ¿sería posible esa confianza y esa libertad sin alguna clase de arraigo institucional?; ¿sin algún tipo de promesa colectiva que limita la libertad, es cierto, pero que también a veces la posibilita? Por último, aunque no por ello menos importante, ¿no estarían los análisis foucaultianos refiriéndose a un régimen disciplinario que ya no es el propio de este momento de la modernidad? ¿No serán, como escribe Deleuze, "las sociedades disciplinarias nuestro pasado inmediato, lo que estamos dejando de ser?" (Deleuze, 1999: 5) ¿No habríamos entrado ya en un orden pospanóptico que no se vertebra a través de instituciones fuertes y normalizadoras, como las que analizara Foucault, sino que opera frente a ellas? (Bauman, 2006a: 16). Un régimen que no establece rutinas arraigadas en el tiempo, sino constantes nuevos comienzos. Un orden, en fin, que hace difícil lo esencial de la tarea educativa, la transmisión de un acervo cultural e intelectual entre distintas generaciones. Esta nueva realidad más desinstitucionalizada ya no puede ser comprendida únicamente a partir de la perspectiva foucaultiana, para quien las instituciones no eran sino los instrumentos de un poder omnímodo, pero nunca un espacio en el que fuese posible construir experiencias más sólidas, que limitan, pero que también pueden garantizar un cierto grado de autonomía y de libertad a los sujetos.

No obstante, lo que a Foucault más le preocupaba era ese poder que ha construido y construye al sujeto moderno. Y aunque esa obsesión fue precisamente la que confirió una particular brillantez e ingenio a su obra, no dejaba de ocultar esa otra dimensión institucional a la que antes se ha aludido.

Esta misma visión de las instituciones como fuentes de dominación estará presente también en la obra de Bourdieu, y particularmente en la de temática educativa. Una dominación que no hacía más, en su opinión, que crear, reproducir y legitimar las distintas desigualdades.

${ }^{41} \quad$ Si bien es cierto que al final de su vida el mismo Foucault previno contra las lecturas dicotómicas de su obra a quienes pensaban que "bajo el poder debieran encontrarse las cosas mismas en su vitalidad primitiva" y que, por tanto, "el poder es malo, feo, pobre, estéril, monótono, muerto", y que sin embargo "está bien, es bueno, es rico" todo aquello sobre lo que se ejerce dicho poder (Citado en Ferry.; Rénaut, 1985: 109). 


\subsection{BOURDIEU: EDUCACIÓN Y REPRODUCCIÓN}

Pierre Bourdieu (1930-2002) ha ejercido también una profunda influencia en la sociología en general, y en el ámbito educativo en particular. Esta influencia ha sido enorme, tanto desde el punto de vista intelectual como social (Alonso, 2009: 77). Su voluntad de influir en el mundo de la educación, expresada en más de una ocasión ${ }^{42}$, la logró ampliamente, sobre todo a través de uno de sus textos más citados, la Reproducción, escrito junto a Jean Claude Passeron (Bourdieu y Paseron, 2001). Texto que ha acabado por convertirse en uno de los clásicos por excelencia de la sociología de la educación, y en el libro canónico de una de las teorías más ampliamente dominantes en este campo (Hattam-Smyth, 2014).

La conciencia de esta influencia fue puesta de manifiesto por Bourdieu a propósito de otra de sus obras de mayor éxito en el campo educativo, "Los herederos" (1973), cuya aparición definió como "un verdadero estallido en el cielo político", porque "fue leído- dijo- por toda una generación y produjo el efecto de una revelación", llegando a ser un verdadero "hecho social". La constatación de que su teoría educativa había impregnado la opinión pública ilustrada la exhibió Bourdieu, en efecto, plenamente. "Hoy- sostuvo- todo el mundo está de acuerdo en decir: sí, sabemos bien que en Francia el sistema escolar reproduce" (Bourdieu, 2008: 148-160).

Su obra, como la de Foucault, se enmarca también en el contexto social del mayo del 68 (Alonso, 2009: 93; Le Goff, 2002: 356-57; Ferry y Rénaut, 1985: 199 y ss). Y como la de éste se construyó también en buena medida como una sociología de la dominación. Una dominación que, según él, se originaba en las estructuras de la sociedad capitalista, que configura, al tiempo que legitima, un sistema de desigualdades que objetivan y reproducen esas mismas estructuras desigualitarias. La educación es para Bourdieu uno de los escenarios esenciales de esa legitimación, ya que presenta como universal lo que no es sino una cultura de clase:

Cualquier clase de enseñanza- afirmó- presupone implícitamente un conjunto de saberes, un savoir faire y, sobre todo, una facilidad de expresión que son patrimonio de las clases cultas (...) ¿ No constituye todo esto una desigualdad básica en torno a ese juego de privilegiados en el que todos han de tomar parte, pues se les presenta engalanado con valores que parecen universales? (Bourdieu y Passeron, 1973: 48).

$42 \quad$ Valga como ejemplo la carta que publicó, a petición del presidente Mitterand, el 27 de marzo de 1985 en nombre del Collège de France (Le Monde de l'Education, mayo 1985) (Bourdieu, 2008: 129 y ss.). 
Todo el ideario igualitarista de la escuela republicana no haría de este modo más que justificar y ocultar este aparato de dominación clasista. "La escuela- escribió- puede mejor que nunca...en una sociedad que se reclama de ideologías democráticas, contribuir a la reproducción del orden establecido, porque logra mejor que nunca disimular la función que cumple" (Bourdieu y Passeron, 2001: 194).

La educación se presenta así, en el lenguaje conceptual de Bourdieu, como un campo- el espacio social que se conforma alrededor de lo que una determinada sociedad valora especialmente- en el que los sujetos pertenecientes a las distintas clases sociales compiten por diferentes posiciones sociales a partir de sus respectivas dotaciones de capital cultural. Para ello, ponen en juego una serie de prácticas, habitus, esto es, esquemas mentales heredados e internalizados, mediante los cuales dichos sujetos perciben, comprenden y evalúan el mundo social. Y de este modo reproducen también y legitiman las condiciones desigualitarias de origen (Bourdieu, 2001). El habitus es, pues, en la terminología de Bourdieu, tanto el producto de las estructuras objetivas del mundo social, como el productor de esas mismas estructuras, que se ponen en práctica cada vez que los sujetos actúan. En suma, es la "interiorización de lo externo y la exteriorización de lo interno" (Bourdieu, 2007: 85 y ss; Bourdieu y Passeron, 2001: 229-230-231).

De este modo se produce una "armonía casi perfecta" entre las estructuras sociales y los habitus, toda vez que "las estructuras objetivas producen los habitus de clase...que, al engendrar las prácticas adaptadas a estas estructuras, permiten el funcionamiento y perpetuación de las estructuras". Es así como "los individuos no esperan nada que no hayan obtenido y no obtienen nada que no hubieran esperado" (Bourdieu y Passeron, 2001: 230 y 223).

La desigualdad social, así engendrada y reproducida, difícilmente puede ser por ello superada, porque la apertura del sistema escolar a grupos previamente excluidos no hace sino acomodarse a una estructura desigualitaria que reserva a los miembros de estos mismos grupos una función similar a la que antes tenían. En efecto, escribe Bourdieu, "aun cuando el deseo de ascenso social a través de la Escuela no es menos fuerte en las clases inferiores que en las clases medias, para aquellas constituye algo onírico y abstracto, tan ínfimas son las posibilidades de satisfacerlo" (Bourdieu y Passeron, 1973: 49). Es así como el sistema educativo se convierte en el locus de la violencia simbólica; en el espacio que legitima la dominación de clase a través de mecanismos culturales. “Toda acción pedagógicaafirma Bourdieu- es objetivamente una violencia simbólica en tanto que imposición, por un poder arbitrario, de una arbitrariedad cultural" (Bourdieu y Passeron, 2001: 19).

Ahora bien, para establecer esta arbitrariedad cultural, el sistema educativo no actúa mecánicamente. Dispone, por el contario, de una autonomía relativa que 
lo sitúa, paradójicamente, en mejor posición para desempeñar la función reproductora y legitimadora de las relaciones de clase:

El sistema de enseñanza- señala Bourdieu- sólo logra realizar perfectamente su función ideológica de legitimación del orden establecido porque...logra ocultar...las relaciones que, en una sociedad dividida en clases, unen la función de inculcación...a la función de conservación de la estructura de las relaciones de clase características de esta sociedad (Bourdieu y Passeron, 2001: 223).

De este modo, los individuos acaban percibiendo lo que no es sino el producto de su "destino social" como "vocación" o "mérito" propio (Bourdieu y Passeron, 2001:234).

Para que este sistema así configurado funcione de la manera más legítima posible, el profesor "debe estar dotado por la institución de los atributos simbólicos de la autoridad ligada a su cargo"; debe, en suma, poseer "las condiciones materiales y simbólicas que le permiten mantener a los estudiantes a distancia y en respeto" (Bourdieu y Passeron, 2001: 152 y 131).

Esta relación de dominación, que tiene lugar en el campo educativo, no haría más que perpetuarse en el tiempo, reproduciendo y consolidando las jerarquías y las desigualdades que hacen imposible cualquier idea de justicia.

La sociología de la educación de Bourdieu se aparta así claramente de la tradición educativa republicana (Alonso, 2009: 81; Le Goff, 1999: 355), para la que la educación era uno de los medios más efectivos de lograr la igualdad, la justicia social y el progreso en una sociedad más libre y democrática. Bourdieu no ve en estos valores más que un velo de legitimación, porque esconden la dominación a la que sirven. "La función más oculta y más específica del sistema de enseñanza- dijoconsiste en ocultar su función objetiva, es decir, en enmascarar la verdad objetiva de su relación con la estructura de las relaciones de clase" (Bourdieu y Passeron, 2001:34).

En este contexto, las tradiciones culturales y educativas sólo cuentan, pues, como mecanismos de dominación (Alexander-Smith, 1998; Grignon y Passeron, 1989: 21-22; Giroux, 1985a: 84). Todas ellas son comprendidas por igual en el marco de las estrategias que utilizan las clases dominantes para imponerse, y poseen, por tanto, la misma dimensión materialista y utilitaria (Alexander, 2000: 107 y ss). No serían más que meras funciones de una realidad social que tiende a reproducirse continuamente. "El único discurso plenamente legítimo- escribe Bourdieu- es el que supone, en cada momento, todo el contexto de la cultura legítima y solamente éste" (Bourdieu y Passeron, 2001: 146). Ni la misma contracultura podría escapar a tal categorización (Ferry-Rénaut, 1985: 235). "La única proposición universal es la idea de que las culturas son arbitrarias” (Bourdieu, 2008: 175). 
Sólo hay un modo de esquivar esta arbitrariedad:

Cuando se cumplen las condiciones sociales de producción de un discurso controlado y refutable, cuando existe un universo social en el cual, para triunfar, es necesario tener razones...argumentos racionales susceptibles de ser sometidos a la justicia del tribunal de la razón, refutables, falsificables sólo por la fuerza de la razón, como se tienen verdades nacidas de la historia y sin embargo independientes de la historia (Bourdieu, 2010: 249).

Ahora bien, ¿ cómo es posible establecer dichas verdades a la vez históricas y transhistóricas? Según Bourdieu "apropiándose de las condiciones económicas y de apropiación de lo universal” (Bourdieu, 2010: 251). No obstante, si esa apropiación no deriva en nuevas ventajas sociales, es porque las razones que unos y otros esgrimen sólo pueden ser confrontadas a la luz de una hipotética razón universal ${ }^{43}$ (Bourdieu, 2010: 249). La conciencia racional del ser humano se elevaría así sobre un mundo que no hace otra cosa que devolverle su propia conciencia. Ahora bien, esta declaración de fe racionalista significa también admitir, como ha señalado Hannah Arendt, que lo que los seres humanos "tienen en común no es el mundo, sino la estructura de sus mentes, y esta no pueden tenerla en común, estrictamente hablando; sólo su facultad de razonamiento puede ser común a todos" (Arendt, 1998: 309). En las condiciones que plantea Bourdieu la verdad dependería entonces más del proceso racional que la ha generado que de su propio contenido. No obstante, tal afirmación supondría entrar en contradicción con su propio análisis, según el cual todo pensamiento y todo juicio no son sino el producto de una determinada estructura de clases.

En cualquier caso, si la verdad solo puede ser conquistada, tal como afirma Bourdieu, en las "condiciones sociales de producción de un discurso controlado y refutable...por el tribunal de la razón" (Bourdieu, 2010: 249), pues todos los demás discursos responden a intereses de clase que se reproducen históricamente, las clases dominadas carecerían entonces de oportunidades para superar sus condicionamientos sociales de origen, puesto que toda apropiación de la cultura escolar por parte de dichas clases estaría destinada a reforzar la estructura social que produce la desigualdad originaria. Desde esta perspectiva, ni es posible la resistencia (Gi-

43 El papel que aquí juega la razón, a la luz de la cual toda acción, razonamiento o juicio lleva incorporado un sesgo de clase, lo desempeña la naturaleza en otra de sus obras clásicas, la distinción. En dicha obra, Bourdieu opone los comportamientos y las actitudes en la mesa, burguesas y populares, en virtud de la lejanía de las primeras a una pretendida naturalidad y de la mayor cercanía de las segundas a ella. "Es el ser contra el parecer- nos dice-, la naturaleza ("franca y directa") y lo natural, la sencillez...frente a la falta de naturalidad" (Bourdieu, 2006: 198). Ahora bien, tanto en un caso como en el otro cabe cuestionar la existencia de una razón o de una naturaleza universal a la luz de las propias categorías sociológicas del propio análisis bourdieusiano, ya que esta razón y esta naturaleza no dejarían de ser también el producto de estructuras sociales que estructuran. 
roux, 1985a: 84), ya que toda conciencia no es sino el producto de la reproducción cultural; ni tampoco la liberación, puesto que la asimilación de una determinada tradición cultural heredada sólo permite mantener el sistema de dominación (Ranciére, 1984). Como dijo Bourdieu, "aquellos a los que la escuela ha liberado ponen su fe en la escuela liberadora al servicio de la escuela conservadora" (Bourdieu, 2008: 150). Como tampoco sería posible la creatividad cultural a través del encuentro entre los miembros de las distintas clases sociales o de las diferentes generaciones.

Desde la teoría social de Bourdieu sólo sería factible, para transcender las desventajas sociales de los sujetos procedentes de las clases sociales más desfavorecidas, "evaluar los grados de mérito proporcionales a la importancia del hándicap superado". Todo ello "conduciría- según dice nuestro autor- a tener por iguales a individuos de rendimientos desiguales y a tener por desiguales a los sujetos de rendimientos idénticos" (Bourdieu-Passeron, 1973: 102-103).

En todo caso, si todos los discursos educativos son discursos de clase, nadie puede ya transmitir legítimamente nada (Bourdieu-Passeron, 2001: 26). La diferencia entre quienes tienen y no tienen conocimientos quedaría así superada, y con ella también la que pudiera existir entre jóvenes y adultos.

¿Cómo resultaría posible, entonces, enfrentarse al hecho de la transmisión inherente a todo proceso educativo? Bourdieu aboga por potenciar la enseñanza basada en la historia para así mostrar el relativismo de todas las creaciones humanas. "Nosotros- escribe- decimos que en tanto que científicos enseñamos el universalismo; y en tanto que científicos del hombre, enseñamos el relativismo ¿Cómo fundar a pesar de todo la unidad?- se pregunta- Bien, ahí está la historia" (Bourdieu, 2008: 175).

Ahora bien, el relativismo no soluciona la cuestión fundamental a la que se enfrenta todo proceso educativo. En efecto, a pesar de las arbitrariedades culturales inherentes a todo orden social, la pregunta sigue vigente, ¿cómo puede establecerse una relación educativa que posibilite una efectiva transmisión del saber entre las distintas generaciones? Porque, como escribió hace muchos años la antropóloga Margaret Mead, los niños "sólo pueden construir con el material que les ofrece la tradición. Liberados a ellos mismos, desprovistos de toda tradición o enfrentados con valores que no pueden respetar, levantarán construcciones sin contenido alguno" (Mead, 1962: 140). Si el único conocimiento y el único valor que los más jóvenes pueden recibir es el de la relatividad de todo lo existente, valorarán únicamente el carácter contingente de todo lo que se les transmite. Pero dicha contingencia no otorga confianza, sino escepticismo, y así es dificil tener razones para actuar en el mundo.

Escapar del relativismo no supone, sin embargo, caer necesariamente en la retórica del tradicionalismo. Significa abrir nuevas posibilidades y oportunidades 
a los que, una vez han conocido y aprendido lo que les ha precedido, tienen que decidir qué hacer con dicho conocimiento (Arendt, 2003b: 296).

Todos los autores que hemos analizado anteriormente se han enfrentado, más o menos conscientemente, al problema del relativismo, en su intento por proponer un modelo educativo totalmente independiente de todo tipo de determinaciones. Una forma de educar en la que los sujetos, libres de cualquier clase de coacciones y de condicionamientos, pudiesen acceder de forma igualitaria y libre al conocimiento.

No obstante, detrás de las propuestas de la pedagogía libertaria y de la sociología crítica, si bien mucho más en el caso de esta última, había un agudo y profundo análisis del mundo educativo. Un análisis que revelaba que debajo de los principios meritocráticos proclamados por las instituciones educativas existía también un sistema de reproducción que favorecía a unas clases sociales a expensas de las otras, presentando esta ventaja como el fruto de un mérito individual que legitimaba la condición del sujeto moderno.

Pero al lado de este análisis existía también, como se ha mostrado anteriormente, una enorme desconfinaza con respecto al orden institucional, y una voluntad, más o menos explícita, de liberar a los sujetos de las cadenas que los oprimían. Esta desconfianza, así como el deseo de liberación que la acompañaba, dejará una profunda huella en la mentalidad educativa posterior.

\section{CONCLUSIÓN. LOS DISCURSOS CRÍTICOS DE LA EDUCACIÓN Y EL NUEVO ESPÍRITU DE LA EDUCACIÓN}

Aunque los sociólogos analizados anteriormente pertenecientes al ámbito de la sociología crítica poco o apenas nada se reconociesen en la obra de los pedagogos libertarios, como Illich y Neill. De hecho, Bourdieu comentó abiertamente en una ocasión, en referencia al primero, lo irrelevante que le resultaba su obra. "Desde mi punto de vista -dijo- no tiene ningún interés, no me interesa” (Bourdieu, 2008: 158159). Aun con todo eso, decíamos, todos estos autores tenían en común una misma actitud crítica hacia el imaginario educativo moderno, del que eran también, por otra parte, sus herederos. Y todos ellos ejercieron también, a su manera, una importante influencia, tanto en la mentalidad de las nuevas clases medias, como en los discursos educativos de uno y de otro signo, liberal y progresista, que incorporaron algunos de los conceptos provenientes de la pedagogía libertaria y de la sociología crítica de la educación (Hattam y Smyth, 2014; Le Goff, 1999: 356 y 368).

Estos discursos tenían un mismo denominador común, a saber, un acentuado individualismo igualitarista, que, con distintos argumentos y finalidades, apela 
constantemente al sujeto frente a la institución para constituirlo en la referencia esencial de la relación educativa (Dubet, 2006: 43 y ss; Gauchet, 2002: 143-144). Desde esta perspectiva, se podría decir que, así como se habla de un nuevo espíritu del capitalismo (Boltanski y Chiapello, 2002), se podría hablar también de un nuevo espíritu educativo que, al igual que aquél, habría integrado buena parte de las críticas efectuadas al anterior espíritu por la sociología crítica y la pedagogía libertaria. Este nuevo espíritu se habría convertido en uno de los principales discursos dominantes en el campo educativo desde los años ochenta del pasado siglo (Le Goff, 2002: 101).

Recordemos cuáles eran las dimensiones principales de la crítica que la pedagogía libertaria y la sociología crítica habían dirigido al programa educativo moderno. Una crítica que, como se ha dicho, acabó conformando la mentalidad educativa actual.

Tanto la sociología crítica como la pedagogía libertaria manifestaron, en efecto, un mismo rechazo al proyecto escolar republicano, basado en la libertad, la igualdad y la justicia social, al considerar que legitimaba un orden desigualitario, opresivo e injusto (Le Goff, 1999: 76). La integración armónica entre individualidad y sociabilidad; entre libertad y autoridad, que aquel proyecto sustentaba fue criticada en busca de una igualdad y de una individualidad más auténticas, no perturbadas por los sesgos institucionales que el sistema escolar imponía (Gauchet, 2002: 136).

Se cuestionó de este modo el monopolio de las instituciones educativas como transmisoras del conocimiento, por su carácter represor y reproductor de un orden desigualitario e injusto (Bourdieu-Passeron, 2001: 19; Foucault, 1999: 211 y ss; Neill, 1997: 210-207; Illich, 1973: 13). Y los saberes escolares no serían otra cosa que la expresión de una dominación que el sistema educativo ocultaba una y otra vez (Bourdieu-Passeron, 2001: 194; Foucault, 1999: 215; Illich, 1973: 99; Neill, 1997: 210-207). La integración en dichas instituciones se identificó, por ello, con la coerción y la represión. Una coerción que sólo podría desaparecer en una situación igualitaria no monopolizada por ningún orden institucional, en el que los sujetos estuviesen llamados a desempeñar un mayor protagonismo. Frente a la transmisión, contaminada por la dominación y la desigualdad que el curriculum escolar ocultaba, se reclamaba así la participación activa de los sujetos en su propio aprendizaje. Una participación que fue reclamada también por la psicología y la pedagogía, las disciplinas que en este contexto fueron elevadas a las más importantes ciencias del aprendizaje, y que como tales fueron las encargadas de legitimar los principios que debían regir la nueva relación educativa (Martin Criado, 2010: 349; Gauchet, 2002: 112; Le Goff, 2002: 101; Varela, 1992: 22 y ss; 1991: 56-57).

Del alumno, integrado y conformado dentro del orden institucional, se transitará así al individuo reconocido por dicho orden en su esencial singularidad 
(Dubet, 2006: 85); y de la tradición de un conocimiento académico legitimado por las instituciones educativas se pasará a otro a la medida de los intereses y de las motivaciones del alumnado. Un conocimiento que tendrán que adapaptarse continuamente a una realidad, considerada fundamentalmente en su dimensión económica y productiva, en constante cambio. Esta nueva concepción de la relación educativa se hará visible en las reformas educativas llevadas a cabo en diversos países entre los años 80 y 90, tales como Francia (Le Goff, 1999: 45 y ss; Reynaud, 1983: 11), España (Varela, 1992 y 1991) y Portugal (Resende, 2010; Lima et al, 2006; Lima y Janela, 2002).

La Pedagogía libertaria y la sociología crítica confluyeron también en un mismo rechazo de la autoridad educativa, del tipo que ésta fuese, al considerar que el enseñante era el portavoz de una institución esencialmente represora y desigualitaria (Bourdieu-Passeron, 2001: 152 y 131; Foucault, 1999: 211 y ss; Neill, 1997: 210; Illich, 1973: 13). Promoviendo así una visión de la relación educativa como una experiencia esencialmente horizontal (Le Goff, 1998: 367). Esta visión del educador como alguien que no debe detentar una mayor posición institucional por tener los conocimientos que otros no tienen, ha influido en los actuales discursos educativos. Éstos rechazan también, en efecto, la posición jerárquica del educador, cuya función se concibe más como la de un guía, o la de un orientador, que como la de una persona cuya autoridad depende del dominio de un determinado campo del saber (Pérez Gómez, 2008: 95; Memorandum de la Comisión Europea, 2000, citado en Laval, 2004: 92 y 182; Le Goff, 1999: 61).

Por último, aunque no por ello menos importante, la sociología crítica y la pedagogía libertaria crearon, asimismo, un discurso educativo centrado en el presente. Para todos estos autores, en efecto, el pasado era la tradición opresora que había que superar. Como había que sospechar asimismo de toda proyección de futuro, porque suponía la prolongación de una realidad que no era más que la reproducción de una situación desigualitaria e injusta. La educación sólo podía ser liberadora si partía de los intereses y de las circunstancias de los que aprenden, en una situación que se actualiza permanentemente en función de dichos intereses. Esta actualización podía realizarse en nombre de una "razón universal nacida de la historia y sin embargo independiente de ella" (Bourdieu, 2010: 249); en el de un sujeto liberado del peso de lo heredado (Foucault, 1986: 30); en el de individuos que desean manifestarse a partir de sus propios intereses y experiencias (Illich, 1973: 33); o en el de una naturaleza infantil que busca realizarse plena y felizmente (Neill, 1997: 26).

Todo ello suponía la ruptura con el eje temporal que había vertebrado el programa educativo moderno, vinculado a la creencia en un progreso, gradual y seguro. Esta ruptura temporal se aprecia también en el imaginario educativo actual, 
articulado por la imagen de un presente en permanente actualización. El presente de unos saberes que tienen que renovarse continuamente (Pérez Gómez, 2008: 88; Bolivar, 2008: 12; Rychen y Salganik, 2004: 21). El de unos sujetos protagonistas de su propia formación, que tiene por finalidad el desarrollo de su capacidad de adaptación, de su autonomía y de su plena realización personal (Pérez Gómez, 2008: 90; Rychen y Salganik, 2004; Le Goff, 1999: 45 y ss). Y el presente también de unos profesores que ya no se legitiman como transmisores de un conocimiento heredado, sino como mediadores de un proceso que exige su constante actualización profesional (Gimeno Sacristán, 2008; OCDE, 1998: 31).

Por todas estas razones, la relación entre individuo e institución, que el programa educativo moderno había establecido, de tal forma que "el individuo se sometía a la sociedad como condición para su liberación" (Durkheim, 2000: 96), fue ampliamente cuestionada, toda vez que aquél se elevaba a principio articulador fundamental de aquella relación educativa. Las instituciones educativas dejaron así progresivamente de ser vistas como ámbitos de incorporación, en relación con un modelo educativo que no trataba tanto de socializar al individuo por la escuela, sino en la escuela (Gauchet, 2002: 120).

Ahora bien, el problema que se plantea en esta situación es ¿cómo conjugar en un mismo acto un proyecto individualizador y otro socializador? (Gauchet, 2002: 116). En otras palabras, ¿cómo anclar la individualización como proyecto sin la fuerza vinculante de los lazos institucionales? Porque sin la máscara institucional se hace difícil construir una individualidad que no se remita continuamente a ella misma, a sus particulares razones. En esta situación el proyecto civilizatorio, tal como fuera concebido por la modernidad, en tanto que interiorización de unos deberes colectivamente sancionados (Elias, 1993a), se disuelve en la personalidad de cada sujeto. De los que tienen sus propias capacidades y dificultades, y también sus propias motivaciones e intereses; y asimismo de los que buscan realizarse a partir de su personal interacción con el mundo que les rodea.

No obstante, la situación anteriormente descrita no respondía únicamente a la influencia ejercida por el pensamiento educativo moderno, tanto en su primera versión como en aquella otra posterior más crítica. Era también el resultado de una serie de procesos sociales relacionados con las transformaciones del papel de las instituciones académicas, impulsadas fundamentalmente por la acción de los Estados, con las mutaciones del universo familiar, y con los cambios en los estilos de vida de la juventud. De todo ello nos ocuparemos en la tercera parte de esta obra. 
PARTE III

PROCESOS Y DINÁMICAS SOCIALES 



\section{CAPÍTULO I \\ DESARROLLO Y RECONFIGURACIÓN DE LA ESFERA EDUCATIVA}

Se puede discutir, criticar, rechazar la pedagogía de los colegios del siglo XIX, la de los institutos de 1930 o la de las escuelas primarias de 1880 (...) El drama es que estos sistemas que caen en la ruina no pueden ser reemplazados por las concepciones demasiado pragmáticas y demasiado funcionales que la sociedad industrial sugiere a la escuela: preparar trabajadores, aprender a aprender, aprender a comunicar, etc. El crecimiento económico y la integración social no pueden disimular por mucho tiempo lo que son: medios a los que la sociedad debe asignar un fin (Prost, 1970: 494).

\section{INTRODUCCIÓN}

Las instituciones educativas han experimentado importantes transformaciones a lo largo del siglo XX. Durante esta última centuria han pasado de ser ámbitos reducidos casi exclusivamente a las élites, a integrar al común de las gentes. Este proceso supuso la expansión de los sistemas educativos occidentales, especialmente con posterioridad a la Segunda Guerra Mundial, hasta alcanzar unas dimensiones sociales y económicas sin precedentes. Se completaba así buena parte del programa educativo moderno, para el que la educación era uno de los principales medios para la creación de una sociedad de individuos libres y autónomos, con las mismas oportunidades de desarrollar sus respectivos talentos.

Pero este programa pronto alcanzó su límite. En efecto, en el escenario que se inauguró a partir de los años 70, en el que los sistemas educativos tenían cada vez más dificultades para cumplir con sus promesas, comenzaron a emerger una serie de críticas procedentes de uno y de otro lado del espectro político. Los sectores más progresistas adujeron que eran estructuras autoritarias y represivas, que, lejos de reducir las diferencias sociales, generaban cada vez más desigualdades. Desde la derecha se argumentó que eran ineficientes, tanto económica como laboralmente. En este contexto, los diferentes Estados iniciaron reformas educativas que acabaron transformando los principios y los fines que habían legitimado el proyecto educativo moderno. 
En el presente capítulo se relatará todo este proceso. En primer lugar, se describirá someramente la emergencia y la consolidación de los sistemas educativos occidentales, atendiendo a las principales etapas de este proceso. En segundo lugar, se mostrará cómo a partir de los años 70, en un contexto de profundas transformaciones de los sistemas laborales y productivos de las sociedades occidentales, las instituciones educativas experimentaron una serie de cambios que han supuesto el replanteamiento del programa educativo moderno en casi todos sus extremos.

\subsection{Ilustración y Liberalismo: CiUdadanía, SUJETo, PROgReso}

La intención de llevar a la práctica, de una manera más o menos sistemática, el programa educativo moderno se inició con el proyecto Ilustrado ${ }^{44}$. Hasta ese momento la educación, vinculada al ideario de la civilidad humanista, había sido el privilegio de una minoría. A partir de la Ilustración, se tendrá sin embargo cada vez más la voluntad de extender la educación a la mayor parte de la población. Aunque en la mayoría de los casos dicha voluntad no se hará realmente efectiva hasta después de la Segunda Guerra Mundial.

Los Ilustrados percibían la educación en consonancia con las necesidades de los nuevos Estados Liberales. Una de estas necesidades tenía que ver precisamente con el espíritu productivo y utilitario que los animaba. Para lo cual se precisaban, tal como había afirmado un famoso Mercantilista a finales del siglo XVIII, "hombres trabajadores y aplicados, pero nunca de sabiondos ni de pedantes" (Genovesi, 1785 I: 95).

Esta misma intención es la que animaba a los impulsores del código civil Prusiano de 1794, el primer Estado que creó en 1810 un sistema de enseñanza público. En él se establecía que "las escuelas y las universidades son instituciones del Estado que tiene por fin la instrucción de la juventud en los conocimientos útiles y científicos" (Luzuriaga, 1994: 154). Las materias que desde este punto de vista tenían, pues, que priorizarse eran las ciencias y las artes. Pero artes eran, en el lenguaje de la época, los distintos oficios. Si en este nuevo escenario las letras aún tenían cabida, no era para formar "un espíritu pedantesco, unas ideas abstractas y unas cavilosidades superfluas"- afirma el marcantilista antes citado-, sino para fomentar

$44 \quad$ Es verdad que en el ámbito protestante había existido ya una voluntad de extender la educación a todo el pueblo, con la intención de crear buenos fieles y súbditos. A este respecto había dicho Lutero, como ya se señaló en la segunda parte de esta obra, que las autoridades públicas debían hacer todo lo posible para que los padres enviasen a sus hijos a la escuela, "no por el afán- señalabade cultivar la ciencia por la ciencia, sino para hacer de la instrucción un instrumento al servicio del Estado y de la Iglesia" (Lutero, 1961a: Introducción y 1961b: 187). Ahora bien, este deseo no se materializó hasta mucho más tarde. 
"un estudio profundo de la naturaleza y unas máximas sólidas dirigidas a la mayor utilidad de los hombres" (Genovesi, 1785 I: 105).

La educación se convertirá por esta vía en una materia de especial interés público, por su contribución a la formación de trabajadores útiles a la república, pero también más capaces e inteligentes. De trabajadores que contribuyan al progreso material de la nación, y también al suyo propio. No obstante, dentro de este marco habrá importantes diferencias entre la instrucción elemental basada en el cálculo y la escritura, dirigida al pueblo, y aquella otra más refinada, con una mayor presencia de contenidos filosóficos y literarios, reservada a las élites (Varela-Álvarez Uría, 1991: 151 y ss).

Esta nueva concepción de la educación alumbrará también una nueva dimensión de la ciudadanía (Ramírez y Boli, 2001; Bendix, 1974). En efecto, si la educación así entendida contribuía a formar buenos ciudadanos, era porque cada uno de ellos sería capaz de aplicarse con esmero, a partir de las enseñanzas recibidas, al oficio que hubiese elegido, contribuyendo de este modo a su engrandecimiento y al de la república.

Se debe considerar, en efecto- escribe Talleyrand, que ocupó distintos cargos políticos en Francia entre el periodo Napoleónico y el de la Restauración- la sociedad como un vasto taller. No basta que todos trabajen, es necesario que todos estén en su lugar (...) La mayor de todas las economías, ya que es la economía de los hombres, consiste en situarlos en su verdadera posición (...) es incuestionable que un buen sistema de instrucción es el primero de los medios para lograr esto (citado en Julia, 1981: 37).

La condición de trabajador y la de ciudadano quedarán así estrechamente vinculadas, y así permanecerán en el futuro (Durán, 2011: 245 y ss).

No obstante, la ciudadanía no se agotaba en estas enseñanzas utilitarias, imprescindibles para formar parte de la república del trabajo. A ellas habría que añadir también aquellas otras, impulsadas por los emergentes Estados Nacionales, destinadas a crear en la infancia la conciencia y el orgullo de su pertenencia a la república (Ozouf, 1984: 185 y ss). Así se podía leer en un texto del método Peigné destinado a la educación de los niños franceses: "cuando seáis hombres ocupareis un lugar en la sociedad. Vuestro primer deber será entonces amar a la patria y obedecer las leyes" (citado en Prost, 1970: 128). La Geografía y la Historia serán las materias fundamentales para inculcar este sentimiento patriótico en la infancia. Aunque este espíritu se tiña otras veces de un tono menos patriótico, para vincularse con el aprendizaje de las virtudes cívicas de una ciudadanía liberal y democrática. "Cuanto más instruidos sean los hombres- escribía Saint-Étienne durante el proceso revolucionario francés- más conocerán el precio de la libertad y la sa- 
brán conservar; cuantas más luces envuelvan a todos más será mantenida la igualdad entre los hombres" (citado en Julia, 1981: 29).

Durante el siglo XIX y la primera mitad del XX, los profesores se irán empapando de este ideario constitutivo de la nueva "fe laica" republicana. "La escuela- afirmaba uno de los más destacados representantes del republicanismo francés a finales del siglo XIX- será de ahora en adelante el templo de la fe de los nuevos tiempos. Es misión de los profesores ser los pastores de este templo" (citado en Prost, 1970: 386). La profesión docente adquirirá así el carácter de una especie de sacerdocio que conferirá una elevada autoridad moral a quienes lo desempeñen (Dubet, 2006: 40 y ss). Un sacerdocio que actuaba en nombre de una nueva doctrina, también salvadora, pero profundamente secularizada. "Nosotros- afirmaba Jules Ferry, el máximo impulsor de la escuela republicana francesa- no tenemos ni dogmas, ni símbolos, ni catecismo que conocer o difundir, no tenemos más que una religión, la cultura intelectual de todos los franceses" (citado en Ozouf, 1992: 273). Una cultura a través de la cual se cree firmemente que puede lograrse la redención y la salvación de todo el pueblo.

La educación se convertirá de este modo en una materia de vital importancia para los Estados a lo largo de todo el siglo XIX. "Dejémosla abandonada- dirá un político liberal- y se verá al instante destruido el nervio más necesario a la conservación y prosperidad del Estado" (citado en Ruíz Berrio, 1970: 14). Los Estados Nacionales irán construyendo así durante todo este periodo, tanto en Europa como en América, los distintos sistemas educativos, destinados a integrar al conjunto de la ciudadanía ${ }^{45}$ (Fernández Enguita, 2001: 45; Luzuriaga, 1994: 181).

\subsection{LA EDUCACIÓn PARA EL PUEblo: LA CREACIÓN DEL SISTEMA DE EDUCACIÓN DE MASAS}

En las primeras décadas del siglo XX fueron imponiéndose gradualmente las concepciones de la educación más progresistas (Bowen, 1985III: 550), a través de

$45 \quad$ Prusia fue el primer Estado que estableció un sistema de educación nacional en 1810, en él se basó el Estado alemán para crear a finales de siglo un sistema de educación estatal y universal. En Francia, la centralización educativa comenzó en la época napoleónica, pero serán las reformas de Jules Ferry (1880-1883) las que establecerán la escuela laica, gratuita y obligatoria. En Inglaterra, en 1870, el gobierno liberal de Gladstone, a través del ministro Foster, inicia el proceso de universalización de la enseñanza, que fue completado más tarde, en 1876, por Disraeli, que estableció la obligatoriedad escolar. En España la ley Moyano establece en 1857 la universalización y la obligatoriedad de la enseñanza. Pero fue en la II República (1933) cuando se creó un sistema de educación universal, estatal y obligatoria. En EE. UU la escuela pública quedó instaurada en torno a 1850. En América del Sur, las recién creadas repúblicas van instaurando los distintos sistemas de educación nacional a lo largo de todo el siglo XIX (Ramírez y Boli, 2001; Luzuriaga, 1994: 181 y ss; Bowen, 1985 III: 335 y ss; Vincent, 1980; Prost, 1970). 
la difusión del pensamiento de autores como Montessori y Dewey, cuya influencia no sólo fue notable en los gobiernos de sus respectivos países, Italia y EE.UU, sino también en muchos otros de Europa y América, sobre todo en las reformas emprendidas después de la Segunda Guerra Mundial (Manacorda, 1987: 526). Durante esta época fue aceptándose como un hecho casi indiscutible que la educación era el mejor medio para favorecer el crecimiento económico y el desarrollo social mediante el aprendizaje cultural, cívico y profesional.

Y para lograr todo ello existía también un fuerte consenso acerca de los conocimientos que las instituciones educativas debían proporcionar al alumnado. Unos pertenecían a la esfera cívica, ética y moral; otros a la humanística, que integraba la geografía y la historia, la lengua y la literatura. Y otros se relacionaban con el cálculo, la aritmética, las ciencias físicas y las naturales. Formaban parte también del curriculum escolar la educación física y la técnica; la primera con un carácter militar, y la segunda claramente profesional (Vincent, 1980: 120 y ss, 187 y ss; Prost, 1970: 122 y ss).

Existía, asimismo, consenso en torno al estatuto del alumnado, obligado a asumir una serie de reglas y de normas prescritas como condición necesaria para su aprendizaje. Reglas y normas que se ponían en práctica en un régimen institucional cerrado, jerárquico y disciplinario (Vincent, 1980: 42 y ss; Prost, 1970: 50 y ss). Había también acuerdo acerca de los conocimientos que debían poseer quienes enseñaban. Conocimientos que se adquirían en las distintas escuelas y facultades, de forma que su titulación reconocía suficientemente su competencia (Vincent, 1980).

En la primera mitad del siglo XX los países más industrializados de Europa y de Norteamérica ampliaron sus sistemas educativos hasta abarcar la educación secundaria, aunque con una fuerte dualidad, pues eran minoría los hijos de las clases trabajadoras que llegaban a esta etapa educativa (Bowen, 1985 III: 554 y ss).

En general, se puede decir que a lo largo de este periodo los Estados destinaron una creciente cantidad de sus presupuestos a la educación, con la intención de instruir a la infancia y a la juventud en los conocimientos básicos necesarios para incorporarse al mundo de la industria.

No obstante, la gran expansión educativa no se produjo en los países occidentales hasta después de la Segunda Guerra Mundial (Prats-Reventós, 2005: 230). Pasada la primera década después de la Gran Guerra, en la que los países europeos fueron recuperándose poco a poco de la ruinosa situación en la que habían quedado, se inició una etapa histórica en la que se dedicaron enormes esfuerzos al campo educativo hasta niveles presupuestarios nunca antes vistos. Los motivos que estaban detrás de esta orientación eran sociales, políticos y económicos. Desde 
el punto de vista político y social, la educación fue considerada como el principal mecanismo de integración y de progreso social, el mejor modo de hacer realidad el principio meritocrático en una sociedad democrática e igualitaria. Cómo afirmaba el sociólogo T.H Marshall a comienzos de los años cincuenta, haciéndose eco del sentir de la época, se trataba de "permitir que el niño pobre demuestre ser tan capaz como el rico. La consecuencia final- concluía- es una estructura de estatus desigual ajustada a las capacidades desiguales" (Marshall, 1998: 67).

Desde la perspectiva económica, la educación fue percibida como uno de los motores principales del crecimiento económico, cobrando fuerza, a partir de los años sesenta, la noción de la educación para el desarrollo (Rodríguez, 1988; Bowen, 1985 III: 655). Se entendía, desde esta óptica, que la educación era un factor clave de la economía. En este ambiente emergió dentro de la ciencia económica la conocida como Teoría del Capital Humano. Con arreglo a esta teoría, se consideró que existía una relación positiva entre el número de personas cualificadas y el progreso económico nacional, y que se precisarían cada vez más personas con estudios para atender a la demanda de unas economías en constante crecimiento. Con este objetivo, los principales organismos internacionales, tales como el Banco Mundial o la OCDE, hicieron recomendaciones a los Estados para que incrementasen sus presupuestos educativos (Rodríguez, 1988). Para dar respuestas a estas inquietudes los gobiernos iniciaron ambiciosos programas de planificación educativa a los que destinaron ingentes recursos ${ }^{46}$ (OCDE, 1991: 13). Dichos programas conllevaron las reformas de los sistemas educativos de la mayoría de los países europeos occidentales, que incluían la universalización efectiva y la prolongación de la enseñanza hasta abarcar las etapas iniciales de la educación secundaria ${ }^{47}$.

El consenso de postguerra acerca de las potencialidades políticas, sociales y económicas de la educación, no sólo permitió, como se ha visto, un crecimiento incomparable de los sistemas educativos; posibilitó asimismo que los valores que estaban detrás de este programa institucional (Dubet, 2006), impulsado y sostenido por los distintos Estados, fuese ampliamente asumido por la mayoría de la

46 El crecimiento del gasto educativo en la década de los años 50 y 60 fue más que notable. En el conjunto de los países de la OCDE dicho gasto representó el 10\% anual, lo que equivalía al doble del crecimiento del PNB (Gobernado, 1988; Prost, 1970: 487).

47 No obstante, la extensión de la obligatoriedad escolar no tuvo la misma intensidad en todos los lugares. Los países Escandinavos fueron los que más avanzaron en este sentido con las denominadas reformas comprensivas emprendidas en los años 50 , que en la práctica significaban la ampliación de la obligatoriedad escolar y la integración de todos los alumnos en la escuela única. El Reino Unido siguió este camino en los años 60, aunque de una forma más tímida. Otros países consumaron estas reformas más tarde. Italia lo hizo en 1972; Francia amplió la escolarización hasta los 16 años en 1959, durante la V República. Los países del sur de Europa establecieron una escolarización obligatoria más modesta. En el caso de España, la Ley Villar Palasí de 1970 creó la Educación General Básica como un sistema de enseñanza universal y obligatoria hasta los 13 años. 
población como el medio principal para alcanzar unas mayores oportunidades de movilidad social, y también una mayor autonomía. La implementación de dicho programa contribuyó por ello en buena medida a la legitimación de los Estados.

\subsection{LA EROSIÓN DEL PROYECTO EDUCATIVO REPUBLICANO}

En los años 70, las causas que habían favorecido el desarrollo de la educación de masas después de la Segunda Guerra Mundial, habían desparecido del escenario. El crecimiento económico continuado que había caracterizado las casi tres décadas posteriores a la Gran Guerra, y que inauguró lo que se conoce como sociedad de consumo fordista, parecía haber llegado a su límite (Alonso, 2005; Piore y Sabel, 1990), y con el parecía ponerse también fin al optimismo que lo había acompañado ${ }^{48}$.

Por lo que a los sistemas educativos se refiere, la asociación tan estrecha que se había establecido en la época dorada de la expansión económica entre cualificación y empleo, y que justificó el desarrollo de la educación de masas, ya no gozaba del mismo predicamento. En efecto, la obtención de un diploma ya no facilitaba como antes el acceso al mundo laboral, y si lo hacía, era en unas condiciones mucho más desfavorables. Aunque las cualificaciones eran cada vez más demandadas, su posesión ya no garantizaba la consecución de un empleo (Serrano, 2000). Paradojicamente, los títulos académicos se devaluaban justo en el momento en que eran también más demandados (Beck, 2006: 241 y ss). Lo que significaba que las instituciones educativas estaban perdiendo su capacidad anterior para asignar, legítima y eficientemente, posiciones sociales de acuerdo con los principios de mérito y capacidad, principios que estaban en la base de todo el ideario educativo posterior a la Ilustración (Habermas, 1999: 141-42).

Desde este punto de vista, el problema no consistía únicamente en una falta de adecuación entre las instituciones educativas y los mercados laborales. Implicaba también el cuestionamiento de la capacidad de dichas instituciones para cumplir eficientemente con el programa Ilustrado en todas sus vertientes.

Este cuestionamiento procedía de todos los sectores ideológicos. En el ámbito de la izquierda aparecieron en los años setenta toda una serie de estudios

48 El agotamiento del sistema económico fordista era un hecho evidente en la mayoría de las economías desarrolladas desde mediados de los años 70 del pasado siglo (Piore y Sabel, 1990), cuando la producción en masa ya no pudo ser absorbida por una población saturada de bienes de consumo duraderos. Todo lo cual dio lugar a la emergencia de un nuevo modelo productivo, conocido como postfordista, más intensivo en tecnología y menos en mano de obra, que produjo un incremento notable de las tasas de desempleo y de precariedad laboral en la mayoría de los países de la OCDE en la década de los 80 y los 90 (OCDE I, 2000: 27 y 41). 
que destacaban el carácter reproductivo y represivo de los sistemas educativos. Dichos estudios, procedentes del campo de la sociología crítica o de la llamada pedagogía libertaria, alcanzaron una gran difusión, y se convirtieron rápidamente, tal como se ha visto en el segundo capítulo de la segunda parte de esta obra, en obras de gran referencia. En el campo de la sociología crítica merecen ser destacados los trabajos de Althusser (1974); Bourdieu y Passeron (2001); Baudelot y Establet (1975); Bernstein (1989); Willis (1988); Bowles y Gintis (1998) y Foucault (1999). En el de la pedagogía libertaria, las obras más influyentes fueron las de Neill (1997) e Illich (1973). Todos estos autores coincidían en criticar las estructuras jerárquicas y autoritarias que articulaban el mundo educativo, así como los procesos de transmisión del conocimiento que a ellas estaban vinculados (Martín Criado, 2010: 30 y ss; Le Goff, 2002: 98). Otros autores pusieron en tela de juicio la igualdad de oportunidades educativas. En EE.UU alcanzó gran difusión el Informe Coleman (Coleman, 1961) y las investigaciones de Christopher Jencks (1972 y 1973), que cuestionaban abiertamente que la educación pudiese contribuir realmente, tal como se había creído, a la igualdad y a la democracia (Bowen, 1985 III: 676).

Fue así extendiéndose la idea, sobre todo entre los intelectuales de izquierdas y entre la población instruida vinculada a dichas corrientes, de que los sistemas educativos no sólo no lograban el objetivo proclamado de democratización e igualación entre las clases, sino que eran, además, instituciones eminentemente alienantes y represivas.

El escepticismo educativo fue también en aumento en el ámbito del liberalismo, sobre todo a raíz de la crisis de mediados de los años setenta (Giroux, 1985b: 6). Esta crisis puso de manifiesto que la creciente oferta educativa que se había producido en los países occidentales en el periodo anterior, no podía ser absorbida por unas economías cada vez más desaceleradas (Coombs, 1985: 29 y ss). Se imponía, por tanto, la reforma de estas instituciones para adecuarlas eficientemente al mercado laboral.

En suma, para los sectores progresistas la educación era un sistema netamente desigualitario y represivo, y para los liberales una actividad que no generaba la rentabilidad económica esperada, y que producía, además, cada vez más desempleo. Las razones políticas, económicas y sociales que habían impulsado el enorme crecimiento de los sistemas educativos después de la Segunda Guerra Mundial parecían ahora desacreditadas.

En este nuevo contexto se propusieron distintas soluciones. Los Liberales, optaron por recetas de eficiencia económica, adecuando la enseñanza al sistema productivo. Se plantearon medidas como reformar el currículum educativo, capa- 
citar a los profesores o mejorar la gestión educativa ${ }^{49}$ (Prats y Reventós, 2005: 17; Terren, 1999: 215-216; Rodríguez, 1988). La palabra más utilizada en este contexto fue la de calidad de la enseñanza (OCDE, 1991:27 y ss). Todas estas medidas estuvieron en boga durante los años ochenta como parte del programa de los gobiernos neoliberales, y continúan estándolo aún hoy en día.

Desde el lado socialdemócrata, por el contrario, se hacía más hincapié en las políticas democratizadoras, sin que ello significase que se obviasen los principios meritocráticos y economicistas. Se proponía así diversificar el sistema educativo, para tener en cuenta la realidad de cada alumno ${ }^{50}$ (Prost, 1970: 492; Enkvist, 2000: 232 y ss).

Los alumnos, en efecto, pasaron a tener un mayor protagonismo en la esfera educativa. A este hecho colaboraron factores tales como el ambiente intelectual creado por aquellas obras aparecidas en los años 70, vinculadas al ámbito de la sociología crítica y de la pedagogía libertaria, para las que los sistemas de enseñanza eran auténticos escenarios alienantes y reproductivos (Torrés Santomé, 2008: 144 y ss). A todo ello ayudó también una corriente que abogaba por la ampliación de los derechos de la infancia, hasta abarcar los de ciudadanía (Gaitán y Liebel, 201.; Renaut, 2002). Pero también una determinada concepción de la enseñanza, que hacía más hincapié en el método que en el contenido, y que en consecuencia estaba más preocupada por el aprendizaje que por la transmisión del conocimiento. Una concepción que recogía en buena medida el legado del pensamiento educativo moderno.

En suma, en las últimas décadas del siglo pasado se fue dibujando un escenario que iba a producir cambios sustanciales en muchos de los sistemas educativos de los países occidentales. Por una parte, fueron decreciendo las esperanzas acerca de la capacidad de estos sistemas para impulsar la igualdad y la democracia. Afirmando, por el contrario, que eran fuente de desigualdad y de represión. Por la otra, se decía que eran ineficientes, tanto económica como laboralmente.

49 A este respecto merece destacarse el Informe Reagan, "A nation at risk". En él se decía que los problemas económicos de los EE. UU se derivaban en buena medida de las deficiencias de su sistema educativo (Morgenstern, 1987). En Inglaterra, las reformas emprendidas por el gobierno Thatcher a comienzos de la década de los 80 iban encaminadas a conseguir una mayor efectividad y eficiencia, para lograr así una mejor adaptación de la educación a los requerimientos del sistema económico y del mercado laboral (Prats y Reventós, 2005: 69).

50 Las reformas llevadas a cabo en Francia y España entre finales de los años 80 y comienzos de los 90 se inscriben en esta perspectiva. En realidad, Francia ya había llevado a cabo una reforma de este tipo con la ley Haby de 1975, que instituyó el "Collège Unique" (Prats y Reventós, 2005: 32.; Raynaud, 1983: 115). Las reformas de los años 80 avanzaron en este mismo sentido (Le Goff, 1999: 37 y ss). Los países del sur de Europa, como España, promulgaron estas leyes entre finales de los años 80 y comienzos de los 90 (LOGSE, 1990). 
En este contexto, se fueron erosionando muchos de los principios que habían legitimado el desarrollo de los sistemas educativos meritocráticos, y que estaban contenidos en el programa educativo moderno. Se cuestionó así el contenido de los saberes, así como el proceso de transmisión de los mismos. En efecto, ¿qué contenidos serían los más adecuados para unos sistemas educativos que se alejaban progresivamente del mundo del trabajo, y que eran además percibidos como crecientemente opresivos, desigualitarios e injustos? Y, además, ¿cómo habría que transmitirlos? En este contexto se produjo una reformulación de los procesos de enseñanza-aprendizaje a partir de discursos procedentes de distintos ámbitos, tanto de las instituciones políticas y empresariales, como de las disciplinas pedagógicas y psicológicas (Raynaud, 1983: 118), herederas a su vez de una tradición enraizada en el pensamiento educativo moderno.

Todo ello desembocará en una creciente desinstitucionalización e individualización de los procesos de enseñanza-aprendizaje, tal como se verá en el próximo epígrafe.

\subsection{LA RECOMPOSICIÓN DEL PROGRAMA EDUCATIVO MODERNO}

A partir de mediados de los años 80 de la pasada centuria los sistemas educativos de muchos de los países occidentales experimentaron una serie de reformas, justificadas en función de la necesidad de ajustarlos a las nuevas necesidades económicas y sociales, y legitimadas con arreglo a un discurso que, tal como se ha mostrado anteriormente, recogía muchos de los principios del pensamiento educativo moderno, tanto en su versión más temprana como en aquella otra posterior más crítica.

Estas reformas se centraron en tres aspectos fundamentales; a saber, la definición de los conocimientos, que se creía tenían que transmitir las instituciones académicas; el papel de los alumnos y la función de los docentes. A desarrollar cada una de estas cuestiones estarán dedicados los epígrafes siguientes.

\subsubsection{Los contenidos y los fines del saber académico}

Como se ha señalado anteriormente, a partir de los años 70 los sistemas de enseñanza de las sociedades industriales más desarrolladas comenzaron a mostrar signos de agotamiento, dado su incapacidad para crear empleo. Todo lo cual repercutía no sólo económicamente, sino también política y socialmente, en virtud de que dicha incpacidad estaba relacionada con la distribución de posiciones sociales legítimamente admitidas. La educación, en efecto, había emergido a lo largo de la 
modernidad vinculada al mundo del trabajo como uno de los principales medios para la realización del espíritu de la época, a saber, una sociedad de individuos libres con las mismas oportunidades de promoción y de ascenso social. Un espíritu que el sociólogo T.H Marshall veía cada vez más realizado a comienzos de la década de los 50, lo que le hacía contemplar el futuro con bastante optimismo:

Por mi parte -dijo- no encuentro rastros de relajación de los vínculos que unen la educación a la ocupación. Por el contrario, parece que se estrechan cada vez más, porque aumenta el respecto por los certificados, los diplomas $\mathrm{y}$ las licenciaturas en la medida en que sirven como cualificaciones para un puesto de trabajo, y no parece que la tendencia disminuya con el paso del tiempo (Marshall, 1998: 66).

Durante las tres décadas posteriores a la segunda Guerra Mundial este optimismo no careció de sentido, ya que los diplomas académicos que otorgaban las instituciones educativas gozaban de amplia aceptación y reconocimiento en el mercado de trabajo, confiriendo posiciones y prestigio a quienes los detentaban (Laval, 2004: 51).

Pero la situación que se inauguró después de tres décadas de expansión económica y educativa continuada posteriores a la Segunda Guerra Mundial, era completamente diferente, debido principalmente al incremento de las cifras de desempleo entre la población que disponía de cualificaciones (Serrano, 2000: 137; Alaluf y Stroobants, 1994: 48; OCDE, 1992: 11). Si bien las credenciales educativas continúan siendo un requisito necesario para acceder al mercado de trabajo, este requisito no era ya suficiente (Beck, 2006: 241 y ss; Miguelez y Prieto, 1999: 188).

Para el relanzamiento del crecimiento, la restauración de la competitividad y el establecimiento de un nivel de empleo socialmente aceptable en la Comunidad- se comentaba en el Libro Blanco de la Comisión para las Comunidades Europeas-, la educación y la formación, al tiempo que mantienen su misión fundamental de promover el desarrollo personal y los valores de la sociedad, tendrán, sin duda, que desempeñar un papel determinante. No obstante- se decía- conviene comprender su carácter, alcance y límites (Comisión de las Comunidades Europeas, 1993: 126).

El hecho de que la educación y la formación se viesen como algo necesario, pero ya no suficiente, estaba directamente relacionado con las transformaciones que experimentó el modelo productivo fordista a partir de los años 70 del siglo pasado, como consecuencia del agotamiento de los mercados de masas. Para reaccionar a esta situación, se diseñaron nuevas estrategias empresariales consistentes en flexibilizar la producción, adaptándola a los cambios en la demanda. Con este objetivo, se hicieron importantes inversiones en tecnología para abaratar costes, 
y diversificar y mejorar la calidad de los productos (Piore y Sabel, 1990: 263 y ss). Como consecuencia de todas estas transformaciones, el nuevo sistema productivo demandó otro tipo de formación más ajustada a sus necesidades, que las instituciones académicas no proporcionaban. De este hecho eran conscientes, no sólo las organizaciones empresariales, sino también las más importantes instituciones políticas internacionales. Así se podía leer en un informe de uno de estos organismos de comienzos de los años 90: "el reproche esencial que se hace a la enseñanza es que las instituciones académicas dispensan cada vez menos conocimientos y cualificaciones necesarias para cuando los alumnos comiencen a trabajar" (OCDE, 1992: 9-10). Se precisaban, pues, otro tipo de cualificaciones más adaptadas a cada lugar de trabajo. "Los jóvenes que abandonan la escuela- se afirmaba en otro de estos informes- tienen necesidad de una gama de cualificaciones y de competencias que sólo en parte se adquieren en un programa tradicional de estudios" (OCDE, 1998: 25-39). Estas cualidades, agrupadas en el concepto de competencias, "exigidas en el mundo del trabajo, que las empresas quieren fomentar cada vez más que se enseñen en las escuelas- se decía en un Informe de la OCDE-, son de orden más general. La adaptabilidad, la facultad de comunicar, de trabajar en equipo, de tener espíritu de iniciativa, estas cualidades y otras competencias "genéricas" son ahora esenciales para asegurar la competitividad de las empresas". Para lo cual se recomendaba "desarrollar una pedagogía nueva en la enseñanza general para formar trabajadores más adaptables y más reflexivos de los que los empleadores tienen hoy necesidad" (OCDE, 1992: 7-11).

No obstante, el nuevo escenario formativo y educativo que emergió a partir de finales de los años 70 no respondía únicamente a una mera adaptación de los sistemas educativos a las demandas del sistema laboral y productivo. En efecto, no sólo se trataba de atender a estos nuevos requerimientos. Se trataba también de que las necesidades del sistema productivo fuesen percibidas como legítimas, manteniendo una actitud favorable hacia el empleo de la población en proceso formativo. Para ello, como señaló Bourdieu, había que dar a los nuevos discursos la forma reconocida como conveniente, pues presentada de otro modo sería considerada inaceptable (citado en Ropé y Tanguy, 1994: 239). En suma, en el contexto laboral y productivo postfordista, en el que las cualificaciones académicas habían perdido el valor que antes tenían, pero en el que seguía siendo necesario vincular la formación al empleo, dicha vinculación tenía que ser funcional para los mercados de trabajo, legitimadora para los Estados, integradora para las instituciones académicas, pero también más motivadora y movilizadora para los sujetos (Boltanski y Chiapello, 2002: 59).

Con este propósito surgieron una serie de discursos procedentes del mundo empresarial, de las principales instituciones políticas nacionales e internacionales, y también de las disciplinas pedagógicas y psicológicas vinculadas a los centros 
escolares. Todos estos discursos trataban de redifinir el contenido de la formación en este nuevo contexto.

Desde el punto de vista empresarial, los representantes del denominado nuevo managament ${ }^{51}$ señalaban la necesidad de oponer al antiguo concepto de cualificación, validado por las instituciones académicas, la noción de competencia, definida como la "capacidad de poner en práctica conocimientos o un saber hacer en el desempeño de una determinada situación profesional” (Génelot, 1992: 210).

Muchas de las reformas educativas llevadas a cabo por los diferentes gobiernos desde la década de los 80 respondían también a este mismo deseo (Bolivar, 2008: 2-3; Le Goff, 1999: 37 y ss). Y la misma intención se podía observar en los informes que las más importantes instituciones políticas internacionales promovieron, fundamentalmente a partir de la década de los años 80 del siglo pasado. En ellos se apelaba a un nuevo concepto de formación que iba mucho más allá de los títulos académicos propiamente dichos. "Sería deseable"- se afirmaba en uno de estos informes- "que los alumnos aprendan a aprender en lugar de aprender para tener un diploma" (OCDE, 2000: 34). Un aprendizaje que debía basarse precisamente en "ciertas disposiciones, aptitudes y competencias del individuo: creatividad, iniciativa, aptitud para la resolución de problemas, flexibilidad, capacidad de adaptación, responsabilidad, aptitudes de aprendizaje y reciclaje" (OCDE, 1992: 9). Y, por encima de todo, "la capacidad fundamental de adquirir nuevos conocimientos y nuevas competencias, "de aprender a aprender" a lo largo de toda la vida" (Comisión de las Comunidades Europeas, 1993: 130). De acuerdo con todas estas concepciones, la OCDE elaboró en el año 2000 un documento, el denominado proyecto DeSeCo (Definición y Selección de Competencias Clave) (Rychen y Salganik, 2004), en el que se definían y seleccionaban las competencias clave que tenían que ser enseñadas y aprendidas en los centros académicos. Estas competencias trataban de superar un enfoque excesivamente academicista de la educación, para privilegiar otro más práctico y funcional, orientado a "hacer frente a situaciones de la vida", esto es, a "la adquisición de capacidades para enfrentar al mundo económico o profesional, resolver problemas sociales, etc..." (Bolivar, 2008: 12; Rychen y Salganik, 2004: 21). Todo ello desde una perspectiva más focalizada en el aprendizaje que en la enseñanza, con el obetivo, se dice, de que los jóvenes sepan "manejar situaciones imprevistas" (Rychen y Salganik, 2004: 22; Bolivar, 2008: 4).

Las competencias se centran, así, más en el hacer que en el conocer, y por ello se relacionan más con la praxis que con la asimilación de contenidos. "La cultura-

${ }^{51}$ En este sentido han proliferado, en especial a partir de mediados de los años 80, una gran cantidad de obras pertencientes al ámbito de la nueva gestión empresarial destinadas a justificar una nueva ética del trabajo más funcional para los contextos laborales postfordistas (Boltanski y Chiapello, 2002). 
afirman los defensores de este discurso- tiene que percibirse como útil, operativa por parte de los estudiantes. El conocimiento como valor de uso" (Pérez Gómez, 2008: 88). Y, asimismo, están más orientadas a incentivar y a estimular el aprendizaje del alumno que a la transmisión de determinados conocimientos por parte del profesor $^{52}$.

En esta misma dirección, aunque desde otra perspectiva, se han pronunciado también los representantes del constructivismo pedagógico, que también otorgan un mayor protagonismo en los procesos educativos al método y al aprendizaje experimental antes que a la transmisión de conocimientos (Torres, 2008: 165; Laval, 2004: 182). Lo que así de pretende es promover otras formas de integración escolar, en un contexto en el que la desmotivación del alumnado es cada vez mayor, al haber perdido las instituciones educativas mucho del encanto que habían tenido en otra época. El constructivismo recurre para ello a un discurso que es el heredero de aquel que había configurado el pensamiento educativo moderno, tanto en su versión más canónica como en la posterior más crítica. En efecto, la idea de que se aprende haciendo arranca con gran fuerza de los postulados educativos rousseaunianos, siendo difundida posteriormente por sus herederos, y relanzada más tarde por Dewey. Y recogida, asimismo, por los principales representantes de la corriente pedagógica libertaria.

En resumen, el discurso de las competencias, que confiere más importancia al aprendizaje práctico, aquél que se adquiere a través de la propia experiencia del sujeto que aprende, más que por medio de la transmisión de quien enseña, ha sido impulsado, como se ve, desde diferentes frentes y con diferentes propósitos. Pero ha desembocado en un mismo cuestionamiento de los saberes vinculados a las anteriores cualificaciones académicas. Estos saberes se entiende que deben ser cada vez más relegados en favor de la adquisición de una serie de actitudes y habilidades, más funcionales para los distintos contextos productivos. Habilidades y actitudes que deben ser adquiridas a través de la propia acción práctica de quienes aprenden.

Esta nueva concepción de la enseñanza y del aprendizaje ha contribuido así a socavar las nociones del saber y de la cultura vinculadas al ideario de la escuela meritocrática, y que los docentes estaban destinados a transmitir (Le Goff, 1999: 44). Todo ello ha incidido en la desinstitucionalización y la individualización de

52 La nueva cultura de las competencias se hermana por ello también perfectamente con las nuevas tecnologías. En efecto, una concepción del saber más preocupada por inculcar habilidades y capacidades que por transmitir conocimientos, más aferrada al método que al contenido, y más atenta a los contextos cambiantes de los nuevos escenarios productivos, confía plenamente en las posibilidades ofrecidas por las nuevas tecnologías. Esta obsesión por las tecnologías es evidente desde hace dos décadas en los discursos de los principales organismos Internacionales y en las reformas educativas emprendidas por los gobiernos (Laval, 2004: 178-179). 
los procesos de enseñanza. Procesos que ahora tienen su razón de ser, no tanto en quienes transmiten el contenido de una determinada tradición académica, como en quienes aprenden a través de su propia experiencia práctica.

\subsubsection{El alumnado como protagonista del aprendizaje}

La tendencia de los actuales discursos educativos a centrarse en el alumnado no obedecía únicamente a las circunstancias por las que atraviesan los actuales escenarios educativos. Está influida, asimismo, por la tradición del pensamiento educativo moderno que, tal como se analizado en la segunda parte de esta obra, se fue articulando progresivamente alrededor del sujeto que aprende. Esta tradición ha sido integrada ampliamente por las modernas disciplinas pedagógicas y psicológicas, que orientan y legitiman la acción educativa en estos términos (Rénaut, 2002; Gauchet, 2002: 123-124; Raynaud, 1983: 119).

El protagonismo que ha adquirido el alumnado en los sistemas educativos fue acentuándose especialmente desde los años 70 de la pasada centuria. Confluían en ello varias circunstancias. Por un lado, las críticas vertidas hacía unos sistemas de enseñanza considerados opresivos e injustos, que puso en cuestión los contenidos del curriculum tradicional en favor de los intereses y las particularidades de cada individuo. La sociología, la psicología y la pedagogía fueron las disciplinas que más legitimaron este discurso (Torres, 2008: 145-146; Dubet, 2006: 89 y 108).

A este protagonismo contribuyó también un amplio movimiento, enraizado en la mentalidad educativa moderna (Arendt 2003a: 289), que abogaba por la progresiva autonomía y emancipación de la infancia, y su inclusión en la esfera pública con una verdadera carta de ciudadanía (Therborn, 1993: 115).

Las consecuencias de todo este proceso fueron especialmente perceptibles con posterioridad a la Segunda Guerra Mundial, aunque en los países nórdicos, particularmente en Noruega y Suecia, comenzaron a ser ya visibles en las primeras décadas del siglo XX. Mientras que, en los países del sur de Europa, tales como España, Portugal y Grecia, esta influencia no se dejó sentir hasta mucho más tarde, en la década de los 80 (Therborn, 1993: 99 y ss).

Todo este movimiento a favor de la ampliación de los derechos de la infancia se formalizó internacionalmente a finales de la década de los años 80 del siglo pasado en la Convención de los derechos del niño, aprobada por la Asamblea de Naciones Unidas el 22 de noviembre de 1989. Se reconocían así una serie de derechos a la infancia, que antes eran sólo privativos de los adultos. Entre estos derechos estaban los de libertad de opinión, de expresión, de pensamiento, de conciencia, de religión, de asociación, de reunión pacífica, e incluso el derecho a que se respetase 
su vida privada (Gaitán y Manfred, 2011: 29; Rénaut, 2002: 375 y ss; Gaitán, 1999: 71 y ss). En esta misma dirección, el Consejo de Europa, en su asamblea de 1996, propuso a todos los Estados miembros la suscripción de un acuerdo para reconocer los derechos de la infancia, en cuyo punto 5 se afirmaba que "el respeto por los derechos de la infancia y una mayor igualdad entre niños y adultos ayudaría a preservar el pacto entre generaciones y contribuiría a la democracia" (Citado en Rodríguez Pascual, 2007: 125).

Todos estos acuerdos, cuya ratificación tenía un carácter vinculante para los Estados firmantes, supusieron un avance significativo para la ampliación de los derechos de la infancia. En efecto, a partir de ese momento la sociedad y los poderes públicos, no sólo reconocían la obligación de protegerla en virtud de su inmadurez y debilidad, protección sin la cual, por otra parte, no es posible formar seres humanos adultos, libres y responsables; sino que, además, se consideraba que, en tanto que otros sujetos con derechos de ciudadanía, la infancia gozaría de un estatuto semejante al de los adultos (Rénaut, 2002: 393 y ss). La edad infantil entraba así por la puerta grande en el espacio público democrático, culminando un proceso, que primero había emancipado a los trabajadores, después a las mujeres y por último a los niños (Therborn, 1993: 96).

A este nuevo estatuto de la infancia tampoco serán ajenas las leyes educativas, que otorgarán a los alumnos un papel mucho más activo y participativo (Gaitán y Manfred, 2011: 122; Therborn, 1993: 111 y ss). Es más, en puridad ya no podrá hablarse de alumnos, de individuos sometidos a unas mismas normas y a unos mismos principios, sino de sujetos considerados, tutelados y valorados en sus particulares contextos de acción e interacción, en su propia individualidad, que habrá de ser suscitada, motivada y desarrollada en todo momento (Dubet, 2006: 86 y ss; Gauchet, 2002: 133; Le Goff, 1999: 46 y ss). Se transitaba así de un programa que trataba de socializar al individuo por la escuela a otro cuyo objetivo era socializarlo en la escuela (Gauchet, 2002: 120). Este hecho es observable en las leyes educativas de distintos países occidentales, tales como España (véase la LOGSE especialmente, pero también la LOE), Francia (Le Goff, 1999: 45 y ss), Suecia o Dinamarca (Enkvist, 2000: 60 y ss) y Portugal (Resende, 2010), por citar sólo algunos ejemplos.

No obstante, este discurso que otorga un papel más activo a la juventud y a la infancia en su proceso de aprendizaje, se ha visto favorecido también, como se ha señalado en el anterior epígrafe, por una nueva concepción de los saberes amparada por distintas esferas, política, empresarial, y por supuesto también académica, especialmente a través de las disciplinas pedagógicas y psicológicas. Esta concepción basada, como se ha dicho, en el concepto de competencias, focaliza extraordinariamente su atención en los alumnos y en sus respectivos contextos de 
aprendizaje (Bolivar, 2008: 13; Laval, 2004: 99; Rychen y Salganik, 2004; Le Goff, 1999: 54; Ropé y Tanguy, 1994: 241). En este escenario se pretende, pues, priorizar la autonomía del alumnado. Y por autonomía se entiende que los estudiantes pongan en práctica su capacidad de aprender en situaciones diversas; que sean ellos mismos los que indaguen e investiguen, y que incluso se atrevan a construir los contenidos de su propio aprendizaje (Pérez Gómez, 2008: 90). En esta línea, el proyecto DeSeCo, elaborado por la OCDE en el año 2000, considera precisamente que la autonomía debe ser una de las competencias clave (Rychen y Salganik, 2004), y señala el camino para su implementación en todos los sistemas educativos de su área (Gimeno Sacristán, 2008: 31 y ss).

En suma, en el protagonismo que ha adquirido la infancia y la juventud en las instituciones educativas han influido una serie de factores. Unos relacionados con los discursos pedagógicos y psicológicos, que, recogiendo una amplia tradición enraizada en el pensamiento educativo moderno, conceden un especial protagonismo al alumnado en los procesos de enseñanza aprendizaje. Otros, vinculados al estatuto otorgado a la infancia por los poderes públicos, en tanto que poseedora de derechos de ciudadanía, anteriormente sólo reservados a la edad adulta; y otros relacionados con los nuevos discursos vinculados a la gestión empresarial, que entienden que la enseñanza debe estar en relación con los contextos productivos y con los intereses de los sujetos. Sujetos, que, a través de su acción práctica, se convertirán en los protagonistas de su propio aprendizaje.

Todas estas circunstancias han influido sustancialmente en la redefinición de la función docente.

\subsubsection{Los nuevos roles docentes}

La tradicional función docente, que estaba legitimada por unos saberes alrededor de los cuales existía un gran consenso, y que eran transmitidos a los alumnos como parte de su proceso de desarrollo personal, en el marco de una sociedad meritocrática y democrática articulada alrededor de las clases. Esta función, decíamos, se ha transformado profundamente en los actuales escenarios educativos. Una transformación relacionada, tanto con la nueva concepción de los saberes, como con el estatuto adquirido por el alumnado en el seno de las instituciones académicas.

En este contexto, ha ido emergiendo una concepción de la educación más experimental y centrada en el sujeto, valorada ante todo por su operatividad en los contextos económico-productivos. Las instituciones políticas y empresariales, y las disciplinas psicológicas y pedagógicas vinculadas a las instituciones académi- 
cas, han contribuido, cada una a su manera, tal como se ha visto anteriormente, a todo ello.

En estas circunstancias, ha cambiado la concepción de la función docente. En efecto, su finalidad principal ya no entiende que sea la transmisión de conocimientos, pues éstos cambian permanentemente a medida que lo hacen los escenarios en los que éstos han de ser aplicados, sino la de proporcionar a los estudiantes las habilidades y las actitudes que tengan una clara aplicación práctica. En todo ello se ha incidido desde diversas perspectivas. Desde las instituciones políticas, desde las organizaciones empresariales, y también desde las disciplinas pedagógicas y psicológicas vinculadas a los centros escolares. Para ejercer esta nueva función ya no será suficiente, pues, la mera transmisión de un conocimiento relativo a unas disciplinas determinadas.

"No se puede contar sólo con la formación inicial para preparar completamente a los enseñantes- se dice desde la OCDE-, en particular en un contexto social, económico y educativo que se modifica rápidamente (...) Esta formación debe ser completada por una formación continua y por un perfeccionamiento profesional" (...). Lo que "será una prioridad de los gobiernos para poner en práctica las reformas educativas” (OCDE, 1998: 17-31).

Lo que precisarán a partir de ahora los docentes serán por tanto otras cualidades que les permitan actuar como una especie de tutores o de guías, acompañando al alumnado en su propio proceso de aprendizaje (Memorandum de la Comisión Europea, 2000; citado en Laval, 2004: 92).

Se ha instaurado así un nuevo profesionalismo docente más técnico- importan más los métodos y los procedimientos que los contenidos-; más individualistacada uno debe probar su competencia-, y continuamente revisable- la formación no es gradual ni acumulativa, sino un proceso en continua mutación, en el que se valoran más las destrezas, el cómo aprender y transmitir el nuevo conocimiento, que el contenido de lo que se aprende y de lo que posteriormente ha de enseñarse. Este profesionalismo ha sido, como se ha visto, especialmente potenciado por las principales organizaciones políticas internacionales, y como tal es parte esencial de los discursos legítimamente proclamados por estas instituciones, que se proponen como auténticos programas de acción para los distintos Estados. "El perfeccionamiento profesional de los enseñantes- se dice desde la OCDE- será una prioridad de los gobiernos para poner en práctica las reformas educativas" (OCDE, 1998: 31).

En esta misma dirección, aunque desde un punto de vista diferente, influido, como se ha visto, por el discurso educativo moderno, actúan las disciplinas pedagógicas y psicológicas, que recomiendan también el abandono de la función tradi- 
cional docente, basada en la mera transmisión de conocimientos, y sus sustitución por otra, en la que el profesor desempeñe el papel de un guía, orientando y acompañando al alumno en su propio proceso de aprendizaje, tratando de motivarlo e incentivarlo (Bolivar, 2015).

En este contexto, muchos Estados han puesto en marcha programas para formar a los docentes en estas nuevas funciones. Este es el caso de las reformas realizadas en Alemania, Reino Unido, Irlanda, Suecia, Suiza, EE.UU, Japón (OCDE, 1998: 67 y ss), Francia (Le Goff, 1999, pp 37 y ss), Portugal (Resende, 2010), o España (Gimeno Sacristán, 2008).

Se ha creado así un escenario bastante diferente a aquel otro vinculado al programa educativo moderno. Para este último, en efecto, la escuela era una especie de santuario laico destinado a formar a todos los individuos en unos mismos principios universales, y también en unos mismos saberes; saberes y principios que los convertirían en personas más capaces, autónomas y libres.

Este proyecto, así formulado, era el resultado del programa civilizador de la modernidad (Elías, 1993). Un programa que incluía la socialización y la individualización en un mismo acto (Dubet, 2006: 48 y ss), y que había sido impulsado por los Estados Modernos. Este proyecto es el que ahora se viene abajo por la misma acción de los poderes que siglos atrás lo habían conformado. En efecto, cuando desaparece una cultura común en la que los Estados y los individuos se reconocen; cuando en lugar de esa cultura emergen saberes instrumentales; cuando los sujetos ya no se definen por una pertenencia común, sino por sus distintas particularidades; cuando los portavoces de estas instituciones tienen cada vez más dificultades para dirigirse a sus miembros en nombre de criterios universales. Entonces, es cuando ese proyecto más se resiente, porque resulta cada vez más difícil invocarlo para continuar educando.

\section{Conclusión}

A lo largo de este capítulo se ha mostrado cómo se ha ido articulando e implementando el programa educativo moderno. De acuerdo con dicho programa, la educación se concebía como uno de los principales medios para socializar e integrar a los individuos, para constituirlos en sujetos orgullosos de su pertenencia, pero también de su autonomía y de su independencia. Esta doble condición, la de la integración y la de la autonomía, se lograba por medio de la socialización de los sujetos en un mismo universo normativo, que constituía la esencia del proyecto civilizatorio moderno, amparado e impulsado por el Estado. 
Un proyecto que se anclaba en una serie de principios. Para la Ilustración y el liberalismo, dichos principios estaban en consonancia con una sociedad estructurada alrededor del trabajo productivo y de una ciudadanía orgullosa de su pertenencia nacional. Se pretendía de este modo que a través de la educación todas las personas fuesen conscientes de sus deberes productivos y patrióticos, y que las élites aspirasen, además, a adquirir los signos de la alta cultura, aquellos que las diferenciaban del conjunto de la población, confiriéndoles una identidad particular y propia.

Posteriormente, sobre todo a partir de la segunda mitad del siglo XX, este programa educativo adquirió un carácter más igualitario y democrático, extendiéndose al conjunto de la población, hasta completar la universalización de la enseñanza, al menos hasta las primeras etapas de la educación secundaria. Fue el periodo de su máxima plenitud, el de su mayor encanto, cuando la educación fue percibida como uno de los principales instrumentos para lograr el progreso material y social de todos los individuos en una sociedad articulada alrededor del trabajo productivo, que se pretendía libre, abierta y democrática, contribuyendo así sustancialmente a la legitimación de los Estados.

Pero esta plenitud, alcanzada en las apenas tres décadas que transcurrieron entre el final de la Segunda Guerra Mundial y los años 70 del pasado siglo, fue seguida del desánimo, a medida que las instituciones educativas perdían sus vínculos con el mercado de trabajo. Y con él surgieron las primeras críticas que tornaron el encanto en desencanto. En este escenario los sectores más progresistas afirmaron que los sistemas educativos reproducían, e incluso favorecían, las desigualdades sociales, y que además tenían un carácter represivo y autoritario. Los más liberales insistieron en que eran incapaces de impulsar el progreso social y económico, distribuyendo posiciones de forma meritocrática.

La respuesta a esta situación fue la reforma del programa educativo republicano en casi todas sus vertientes, reconsiderando las principales dimensiones que lo habían articulado y legitimado durante un perido dilatado de tiempo. Se sometieron así a crítica los saberes académicos desde varias instancias. Tanto por parte de los representantes de las organizaciones empresariales, como de las instituciones políticas, y también de las disciplinas pedagógicas y psicológicas. Desde todos estos lugares se cuestionó su contenido con distintos argumentos, para proponer su transformación en un sentido más individualista, en relación con las particularidades y los intereses de cada sujeto, más utilitario y más práctico.

De acuerdo con esta misma voluntad de reforma, el alumnado adquirirá también un mayor protagonismo, tanto en relación con una concepción de la educación más vinculada al aprendizaje que a la enseñanza, como con el nuevo estatuto que adquirió la infancia, como portadora de una serie de derechos de ciu- 
dadanía, antes reservados sólo a los adultos, que la integraban en la esfera pública democrática.

Asimismo, también será sometida a reforma la profesión docente. En este contexto, los profesores ya no serán reconocidos ni por las instituciones políticas y empresariales, ni tampoco por las disciplinas psicológicas y pedagógicas, como los portavoces de un conocimiento que ya no monopolizan ni encarnan. Más que transmitir conocimientos, lo que se les pedirá entonces es que prueben sus competencias, tanto en relación con las necesidades cambiantes del mundo económico y productivo, como con los intereses y las particularidades de los alumnos, a los que tendrán que orientar en su propio aprendizaje utilitario y práctico. Y como todas estas competencias tienen que adptarse a todos estos entornos cambiantes, los docentes tendrán que estar abiertos a un proceso de actualización continúa.

Todo este nuevo programa educativo ha sido ampliamente legitimado por los discursos pedagógicos y psicológicos, que reproducen en sus discursos muchos de los principios establecidos por el pensamiento educativo moderno, incluso en su versión más crítica.

En este escenario, el programa educativo moderno se ha ido separando gradualmente del proyecto civilizatorio al que había estado vinculado desde su mismo nacimiento. Y con esta separación caen también las máscaras de la civilidad que lo encarnaban (Sennett, 2011: 325). Esas máscaras que posibilitaban el trato con el otro como con un otro, consciente también de su propia responsabilidad individual e institucional. Lo que queda en su lugar son unas relaciones mucho más individualizadas y desinstitucionalizadas, en las que unos, los alumnos, exhiben su yo más personal, y otros, los profesores, ponen en juego sus propias capacidades y habilidades, incapaces de recurrir a normas institucionales que casi nadie ya reconoce. En este escenario individualizado el código que impera no puede ser otro que el de la orientación terapéutica, destinada a devolver al sujeto a su yo más íntimo y personal, cuando es herido por la imposibilidad de manifestarse en medio de los demás.

Todo ello hace que las instituciones escolares permanezcan en un espacio fronterizo entre lo privado y lo público. En efecto, por un lado quieren regularse cada vez más por los principios democráticos que rigen en el espacio público; pero, por el otro, abandonan estos principios cada vez que dan cabida a las reivindicaciones más privadas y personales de cada sujeto.

$\mathrm{Y}$, sin embargo, dichas instituciones tienen que dar también cabida a sus promesas, viéndose así atrapadas en la siguiente contradicción; a saber, cómo hacer compatible la dimensión más meritocrática e institucional con aquella otra más personal e individual. Contradicción a la que a su vez se suma el universo de la familia, tal como se verá en el próximo capítulo. 



\title{
CAPÍTULO II \\ LAS MUTACIONES DEL UNIVERSO FAMILIAR
}

\begin{abstract}
Creo que a medida que las costumbres y las leyes son más democráticas, las relaciones entre el padre y el hijo se hacen más íntimas y benignas, hay en ellas menos etiqueta y menos autoridad; la confianza y el afecto suelen ser mayores, y parece que el lazo natural se hace más apretado, en tanto que se afloja el lazo social (Tocqueville, 1993II: 166-167).
\end{abstract}

\section{INTRODUCCIÓN}

La familia es una de las instituciones sociales que más cambios ha experimentado en las últimas décadas, al menos por lo que se refiere a las sociedades occidentales industrializadas. No obstante, esta transformación no ha supuesto, como algunos vaticinaban hace ya varias décadas, su declive. Muy al contrario, la familia es una de las instituciones más valoradas, como así lo atestiguan continuadamente numerosas encuestas desde hace ya bastante tiempo.

Ahora bien, esta valoración se produce en un contexto en el que la institución familiar ha experimentado también profundas transformaciones, que han influido en su función socializadora y transmisora. La finalidad de este capítulo es analizar este proceso mostrando los cambios en las actitudes y en los valores de padres e hijos a lo largo de tres diferentes periodos, y la incidencia que todo ello ha tenido en los procesos educativos. Para ello, nos hemos centrado en la familia española, con algunas referencias comparativas también a la portuguesa, particularmente con respecto al último de los tres periodos considerados.

Con este propósito, se han diferenciado tres etapas que marcarían el cambio familiar anteriormente señalado. A saber, la de los años 60, caracterizada fundamentalmente por la reproducción social. La de 1975-1985, en la que predominaría la distancia ideológica y normativa entre las distintas generaciones de jóvenes y de adultos. Y la posterior a 1985, en la que se acorta aquella distancia generacional en el marco de una familia más democrática, individualista y afectiva.

Este proceso no se ha apartado esencialmente del que tuvo lugar en el mundo occidental, razón por la cual la primera parte del capítulo estará dedicado a describir someramente las principales etapas que lo jalonaron. 
En la segunda parte, se analizarán los cambios en las actitudes y en los valores familiares de jóvenes y adultos españoles, haciendo comparaciones también con Portugal en relación con la última de las tres etapas diferenciadas. Para ello se ha recurrido fundamentalmente a los distintos Informes de Juventud que se vienen publicando en España desde los años 60, y que incluyen habitualmente un apartado sobre la familia. Esta larga serie de Informes, apenas equiparable con casi ningún otro país del mundo (Zárraga, 2015: 14; De Miguel, 2000: 15), permiten, a pesar de algunas de sus debilidades, que han sido alguna vez puestas de relevancia (Martín Criado, 1998), hacer un seguimiento de los procesos de cambio antes indicados. Seguimiento que es mucho más difícil de hacer en el caso de Portugal, razón por la cual se han limitado las comparaciones con el vecino país ibérico fundamentalmente al periodo posterior a 1985.

\subsection{LA FAMILIA TRADICIONAL: TRANSMISIÓN Y REPRODUCCIÓN SOCIAL}

Si consideramos la situación de la familia en Europa occidental desde el final de la Edad Media hasta el siglo XVIII, se puede decir que esta institución se mantuvo como una comunidad abierta, tanto interior como exteriormente (Stone, 1990: 69; Harris, 1986: 170; Shorter, 1977: 255 y ss). En los estratos sociales menos acomodados la casa era poco confortable y con la mayoría de las estancias comunes, incluso los dormitorios. En los grupos sociales más favorecidos la confortabilidad era mucho mayor, pero el espacio doméstico era también un lugar en el que convivían un gran número de personas, entre parientes y sirvientes de todo tipo, sin que hubiese una esfera propia e íntima reservada a los esposos y a los hijos. Era frecuente que en las casas de los sectores sociales más acomodados existiesen habitaciones comunicadas sin una función concreta, por las que circulaban niños, sirvientes y visitas, participando todos ellos de una sociabilidad amplia y comunitaria. Estas visitas eran también frecuentes en los hogares más humildes, como los de los campesinos, para animar las veladas nocturnas (Ariès, 1987: 520 y ss; Flandrin, 1979: 119-136 y ss). En efecto, tanto en estas casas como en las de los grupos más acomodados, y particularmente en estas últimas, se participaba de una densa sociabilidad presidida por frecuentes y numerosas reuniones sociales, conforme a la práctica de la buena hospitalidad (Stone, 1990: 94-95). En estas circunstancias, era muy difícil que se despertasen los sentimientos afectivos e íntimos que caracterizarán a la familia moderna (Aríès, 1987: 527).

Esta profusa y variada sociabilidad, tanto en el interior como en el exterior de la familia, estaba atravesada por relaciones jerárquicas de distinto tipo, lo que quizás explique que la proximidad física no produjese demasiado rechazo personal, al darse entre personas cuyo rango era indiscutible para todo el cuerpo social (Flan- 
drin, 1979: 120-136). Dicho de otro modo, la mezcla entre personas de distinta categoría y edad era posible porque todo el mundo estaba seguro de su posición en la sociedad (Ariès, 1987: 543-544), por lo que prácticamente nadie temía perder su identidad en medio de esta densa vida social. El recelo a la multitud es un sentimiento propiamente moderno, que emerge en la gran ciudad industrial, mucho más igualitaria y anónima, y su contrapunto es la exacerbación individualista, como bien demostró Simmel (2001).

La familia preindustrial fue, en efecto, al menos hasta el siglo XVIII, claramente autoritaria y jerárquica. $Y$ esta condición se manifestaba tanto en la relación entre los esposos, como entre el padre y los hijos. No obstante, esta autoridad fue declinando paulatinamente a lo largo de los siglos XVII y XVIII, a medida que el cristianismo pregonaba ciertos deberes de reciprocidad paterno-filiales (Flandrin, 1979: 154 y ss; 168 y ss). No obstante, la jerarquía y la autoridad no anulaban los sentimientos y los afectos entre padres e hijos, si bien los situaban en el marco de las obligaciones que prescribían dichas relaciones jerárquicas. Porque la familia era, en efecto, "una realidad moral y social, más que sentimental" (Ariès, 1987: 488). También para los esposos, razón por la cual el matrimonio por amor no triunfó hasta que la familia dejó de ser el principal resorte de la reproducción económica y social (Stone, 1990: 81), lo que no ocurrió, en la mayoría de las clases sociales, hasta el siglo XX (Flandrin, 1979: 222). Aunque no por ello el amor estaba necesariamente al margen del matrimonio. Como escribió el historiador John Boswell:

En la Europa premoderna el matrimonio empezaba generalmente como un acuerdo en función de la propiedad, continuaba con la crianza de los hijos y terminaba en amor. De hecho, pocas parejas se casaban "por amor", pero muchas llegaban a amarse con el tiempo, al administrar conjuntamente su casa, sacar adelante a su prole y compartir sus experiencias vitales. Casi todos los epitafios que se han conservado de la época dedicados a los maridos o esposas expresan un profundo afecto (Citado en Giddens, 2007: 233-34).

La situación hasta aquí descrita, que caracterizó a la familia tradicional, empezó a cambiar a partir del siglo XVIII, primero en el seno de la burguesía y la nobleza, y posteriormente en los demás grupos sociales (Anderson, 1988: 46). Fue entonces cuando comenzó un proceso de gradual y creciente privatización y sentimentalización del ámbito familiar (Ariès, 1987: 528).

Tal proceso comenzó a ser visible en la arquitectura doméstica, aumentando el número de estancias comunicadas por pasillos, destinadas a sirvientes, mujeres y niños (Ariès, 1987: 528; Harris, 1986: 182; Flandrin, 1979: 119-120), y disminuyendo los espacios comunes, tales como los patios y los salones, que anteriormente acogían una amplia y densa sociabilidad, y que ahora serán sutituidos por 
la sala, más íntima y privada (Habermas, 1982: 81 y ss). En esta misma dirección, se observó también el declinar de las visitas, que hacían de la casa un lugar de hospitalidad, de reunión y de sociabilidad (Stone, 1990: 95; Anderson, 1988: 48; Shorter, 1977: 287). El espacio doméstico se fue así configurando como un lugar compartimentalizado, en el que la esfera familiar y la social se separaron cada vez más, emergiendo una familia cada vez más reducida y replegada sobre sí misma, en la que tenían cada vez menos presencia los cridados, los parientes y las amistades (Ariès, 1987: 529 y ss).

Todos estos cambios exigían nuevas actitudes y nuevos valores, y por tanto también una nueva sociabilidad, menos atenta a los rituales y a la ceremonialidad de la familia estamental. Esta nueva moral iba a estar presidida por una relación más estrecha entre padres e hijos. Los hijos, en efecto, serán objeto de mayores atenciones materiales y personales, procurando su educación y su promoción (Ariès, 1987: 532-533). Gradualmente irán adquiriendo un papel cada vez más protagonista. Alrededor de ellos se despertará una nueva sensibilidad que, tal como se ha mostrado en la primera parte de esta obra, contribuirá a alejarlos progresivamente de las esferas propias del mundo adulto (Stone, 1990: 149-150).

Este proceso se inició primeramente, a partir del último tercio del siglo XVII y comienzos del XVIII, en los estratos nobles y burgueses, aunque predominantemente en estos últimos, para extenderse más tarde a los demás grupos sociales (Stone, 1990: 150; Ariès, 1987: 537). Desde ese momento comenzará el proceso de transición hacia la familia moderna.

\subsection{LA FAMILIA MODERNA: ENTRE EL LAZO INSTITUCIONAL Y EL SENTIMENTAL}

A partir del siglo XVIII se irá imponiendo en las sociedades occidentales industrializadas un nuevo tipo de familia, que primeramente será típicamente burguesa, y que más tarde, sobre todo a partir del siglo XX, especialmente después de la Segunda Guerra Mundial, se extenderá a los demás estratos sociales ${ }^{53}$ (Singly, 2007: 32; Shorter, 1977: 279 y ss). Se trata de un grupo familiar articulado alrededor de un matrimonio basado en el amor y el compañerismo entre los esposos, $y$

53 De todos modos, este proceso no fue lineal, observándose una amplia variedad entre regiones y países europeos, incluso tan próximos como Francia e Inglaterra. En este último país parece que los cambios en la familia se produjeron antes, desde comienzos del siglo XVIII, en el contexto de la clase media y alta, mientras que en Francia dichos cambios no tuvieron lugar hasta finales de la citada centuria (Anderson, 1988: 56-57). No obstante, todas estas diferencias evolutivas no impiden trazar un cuadro general de la evolución de la familia moderna en el mundo Occidental (Singly, 2007: 20). 
orientado al cuidado, el afecto y la educación de los hijos (Stone, 1990: 219; Shorter, 1977: 279-280). En este nuevo contexto familiar, más cerrado sobre sí mismo, la densa sociabilidad de la familia preindustrial, más abierta al exterior y a la convivencia de jóvenes y adultos, irá desapareciendo en favor de unas relaciones familiares más estrechas, en las que los hijos tendrán su propio lugar al lado de los padres, al margen de otras influencias externas (Lash, 1984: 28).

Esta nueva familia nuclear, replegada sobre los esposos y los hijos, será, en efecto, mucho más individualista que su predecesora la preindustrial (Anderson, 1988: 50); aunque este individualismo se inscriba, no obstante, en el ámbito de las obligaciones que imponía la propia institución familiar. De este modo, los impulsos individualistas que generaba el nuevo escenario familiar se resolvían, no sin tensiones, dentro de un marco normativo que legitimaba la autoridad del padre y la desigualdad de roles entre los esposos (Stone, 1990: 248). El hombre, en calidad de "ganador de pan", era el encargado de procurar el sustento de la unidad familiar; mientras que la mujer tenía reservado el papel de proveedora de los numerosos cuidados y afectos que requerían los hijos (Illouz, 2010: 142; Singly, 2016: 165 y 2007: 20). Esta forma familiar, parcialmente desmercantilizada, permitía compatibilizar las necesidades productivas de la sociedad industrial y las reproductivas de la colectividad, a costa de preservar la asignación tradicional de roles dentro de la unidad familiar (Beck y Beck-Gernsheim, 2003: 172 y 2001: 45). No obstante, el rol del padre como proveedor de recursos y garante de la autoridad, legitimaba cada vez menos esta última función. En efecto, su ausencia del ámbito familiar impedía que pudiese presentarse como un ejemplo para los hijos, que percibían su autoridad como un principio cada vez más lejano y carente de sentido (Lasch, 1999: 210 y ss).

La institución familiar, así entendida, tenía también como objetivo incentivar la reproducción y la movilidad social de sus descendientes, lo que reforzaba la asignación de posiciones de una manera considerada apropiada y legítima (Willis, 1988). Todo lo cual conllevaba una presión social y cultural sobre los hijos, que contrarrestaba las fuerzas individualistas que comenzaban a emerger en el seno de la familia.

No obstante, poco a poco, comenzaba a asomar una distancia generacional entre padres e hijos, expresión de valores y estilos de vida cada vez más diferentes. Una distancia causada por la prolongación de la edad escolar, la demora en la incorporación al mundo del trabajo y una vinculación cada vez más estrecha con la esfera del consumo. Todo ello acabó desembocando en un conflicto generacional, que comenzó a manifestarse en la década y media posterior a la Segunda Guerra Mundial, y que retrató convenientemente el cine y la literatura. Un conflicto que protoganizaron aquellos jóvenes que más tarde educarán a la generación posterior en un ambiente más permisivo y tolerante, acortando así la distancia moral e 
ideológica con respecto a sus hijos, todo lo cual dará lugar a unas relaciones familiares más democráticas, próximas y afectivas, tal como se mostrará en el siguiente epígrafe.

\subsection{DE LA FAMILIA REPRODUCTIVA A LA CONVIVENCIAL, DEMOCRÁTICA E INDIVIDUALISTA}

La familia experimentó una gradual transformación en el mundo occidental en las dos últimas décadas del pasado siglo. Dicha transformación conllevó un mayor individualismo e igualitarismo, y también la intensificación de los lazos afectivos.

Todo este proceso comenzó a percibirse en el mundo occidental más industrializado a partir de los años 70 del pasado siglo, y se aceleró especialmente en los años 80 de la citada centuria (Illouz, 2012; Beck y Beck-Gernsheim, 2003).

Este proceso estaba relacionado con la desaparición de la familia, tal como había estado estructurada hasta los años 60 del siglo XX, con el hombre como procurador del salario y la mujer como cuidadora de los hijos, unos hijos que requerían cada vez más atenciones materiales, afectivas y educativas (Singly, 2016: 165 y 2007: 20). Este tipo de familia conservaba aún importantes elementos tradicionales e institucionales, que actuaban como barrera contra los impulsos individualistas e igualitaristas. Pero que permitían también que las funciones reproductivas y las productivas se integrasen en ella sin demasiado conflicto (Beck y Beck-Gernsheim, 2003: 172 y 2001: 45-46).

Toda esta realidad comenzará a cambiar, como antes se ha señalado, a partir de los años 70 de la pasada centuria. Una de las dimensiones fundamentales de este cambio fue la incorporación de la mujer al mercado de trabajo, que le otorgó una mayor libertad para decidir en casi todos los ámbitos de su vida. Todo ello supuso un importante avance en el ámbito de la democratización de la familia. En donde antes existía imposición se habría ahora la negociación y el acuerdo en torno a ámbitos tales como el cuidado y la educación de los hijos, o las carreras laborales de cada uno de los miembros de la pareja (Singly, 2007: 11 y ss; Beck y Beck-Gernsheim, 2003: 174-175).

Emergió así una familia mucho más relacional, igualitaria, individualista y electiva, que debía solventar a través del acuerdo y de la negociación muchos de los asuntos que antes se integraban en el marco institucional de la familia desigualitaria de la primera modernidad, y que ahora tenían que resolverse en la esfera subjetiva de la propia pareja, sin modelos preestablecidos a los que atenerse (Illouz, 2010: 143-144; Beck y Beck-Gernsheim, 2001: 55-56). 
Este nuevo modelo familiar, mucho más personalizado y democrático, y más basado en la comunicación y en los sentimientos, tanto entre los miembros de la pareja como entre padres e hijos, conforma un tipo de relaciones que han sido denominadas puras (Giddens, 2006: 90 y ss; 2005: 74 y ss). Las relaciones puras se caracterizan por su inestabilidad, ya que resulta cada vez más difícil sostenerlas, especialmente cuando se agudizan las contradicciones entre las funciones productivas y las reproductivas (Beck y Beck-Gernsheim, 2001: 60-61).

En este escenario, los hijos adquieren la condición de bien preciado; el depósito imperecedero de un amor a salvo de todo tipo de riesgos. En ellos se depositan, pues, todas las esperanzas; sobre todo las del amor y los afectos, procurando su realización personal sin menoscabo de su bienestar y su felicidad. No obstante, es tanto lo que se espera de ellos, el deseo de promover su autonomía y su felicidad como camino para su desarrollo personal, por una parte; su éxito académico y social, por la otra. Que no pocas veces los padres se ven enfrentados a la difícil tesitura de equilibrar ambas dimensiones. Tratando de ser cercanos y afectuosos con ellos muchas veces; procurando inculcarles hábitos y normas de obediencia, otras (Singly, 2016: 147 y ss). Sin que esta última dimensión, más normativa y disciplinaria, contenga aquella otra más relacionada con su bienestar y su satisfacción personal. Por esta razón, las relaciones entre padres e hijos son más hedonistas que sacrificiales, orientándose más a la inmediata liberación personal y afectiva que a la postergación de la gratificación. Y por eso se tornan también cada vez más cercanas y menos autoritarias; más basadas en los sentimientos y en la negociación que en la imposición (Alberdi, 1999: 147; Harris, 1986: 286 y ss). Por este motivo la educación de los hijos está también más orientada a procurar su desarrollo y su realización personal, que a la transmisión de normas y de valores (Singly, 2016: 119 y ss; 145 y ss.; 2007: 97-98; Beck y Beck-Gernsheim, 2001: 166-167; Meil, 1999: 113); y por eso persigue también más su liberación personal que su integración. De ahí que en muchas ocasiones la voluntad liberadora de los sujetos se encuentre con la voluntad integradora de las instituciones, y que este encuentro se resuelva acudiendo a los profesionales de la orientación, que tratan de resaturar aquella voluntad subjetiva herida devolviéndola a su propia individualidad.

En un contexto como este, en el que la familia se hace más afectiva, democrática, individualista, relacional y electiva, no dejan de crecer los sentimientos positivos hacia ella. De ahí, que aparezca casi siempre como una de las instituciones más valoradas en casi todas las encuestas (Singly, 2007: 22). Pero esta valoración, como se verá en el siguiente epígrafe, está más relacionada con la satisfacción material y sentimental que procura a sus miembros, que con su carácter de institución transmisora de normas y de valores. Desde este punto de vista no ha dejado de perder relevancia en las últimas décadas. 
En lo que sigue, se ilustrará el proceso de transformación de la familia occidental, anteriormente descrito, con el análisis del cambio de las actitudes y de los valores de padres e hijos españoles de tres diferentes periodos, comparando este proceso con el ocurrido en Portugal, sobre todo con referencia al último de los tres periodos considerados.

\subsection{ACTITUdeS y VAlores de PAdRes e hiJOS. ANÁlisis de 3 GENERACIONES}

El proceso de modernización de la familia occidental, anteriormente descrito, tuvo lugar con mayor retraso en los dos vecinos países ibéricos. Retraso que ha ido seguido de una posterior aceleración, que se ha traducido en una menor duración de las etapas que habían recorrido previamente otros países occidentales más desarrollados industrialmente. Así, entre comienzos de los años 60 y finales de los 90 del pasado siglo se transitó de una familia tradicional a otra moderna, y de esta a la postmoderna. Todo ello en un periodo de apenas tres décadas.

El objetivo que aquí se persigue es analizar los cambios en los valores y en las actitudes hacia la familia de padres e hijos, especialmente los situados en edad juvenil, con la intención de observar cómo han influido dichos cambios en los procesos de socialización y de trasmisión de normas y de valores, y por tanto también en los patrones educativos.

Para realizar este análisis se ha recurrido a las numerosas encuestas y estudios de Juventud que se han publicado periódicamente en España desde los años 60, y que normalmente incluyen un apartado específico sobre la familia ${ }^{54}$. Dichos estudios permiten seguir, pese a sus limitaciones, que han sido señaladas oportunamente en varias ocasiones (Martín Criado, 1998), los cambios experimentados por la familia española en el terreno de las actitudes y de los valores.

Aunque en este análisis se ha priorizado la comparación con Portugal, los datos sobre este país, en lo relativo a los dos primeros periodos de los 3 de los que consta este estudio, son más bien escasos, siendo mucho más abundantes con respecto al último periodo, el posterior a $1985^{55}$, para el que se han tenido en cuenta, asimismo, los datos procedentes de la Encuesta Europea de Valores (EVS).

54 Esta fortuna, de contar con una larga serie de encuestas de juventud, apenas es compartida por ningún otro país (Zárraga, 2015: 14; De Miguel, 2000: 15).

${ }_{55}$ En el caso portugués, las encuestas y estudios sobre los jóvenes son mucho menos numerosos que en España. Es de notar que en este país los estudios generalizados sobre la juventud comienzan a realizarse en la década de los 80 , particularmente a partir de la primera encuesta a los jóvenes llevada a cabo por el Fundo de Apoio aos Organismos Juvenis (FAOJ) en 1982. No obstante, a 
Precisemos un poco más cómo se han estructurado los tres periodos en los que hemos dividido nuestro análisis. El primero se correspondería con el inicio de la década de los años 60, momento en el que aparece la primera encuesta española de juventud. En dicha encuesta se muestra un modelo familiar que en muchos aspectos es todavía tradicional y reproductivo. El segundo periodo se situaría entre mediados de los años 70 y los 80 . En él predominaría un modelo de familia con un componente institucional todavía importante, aunque comienza ya a manifestarse la ruptura generacional, ejemplificada en la creciente disonancia entre el modelo normativo e ideológico de padres e hijos. Lo que no obstante era compatible con la armonía sentimental y afectiva. Por último, a partir de los años 90, emerge un modelo familiar más democrático, negociador y convivencial, que empezaba ya a asomar en el periodo anterior. Así, va reduciéndose sustancialmente el desacuerdo normativo e ideológico entre padres e hijos, al tiempo que se erosiona la dimensión más reproductiva y normativa de la familia.

Podríamos calificar la familia de cada uno de estos 3 periodos con los siguientes adjetivos. La de los años 60 sería básicamente reproductiva; la del segundo periodo se caracterizaría sobre todo por el disenso normativo e ideológico; y la del tercero sería ante todo convivencial.

A continuación, analizaremos cada una de estas tres estas etapas más pormenorizadamente.

\subsubsection{Juventud y familia en los años 60 . Entre la reproducción y la aspiración}

En los años 60 se realizaron en España dos encuestas nacionales de juventud, las de 1960 y 1968. La encuesta de 1960 tuvo la virtud de ser la primera de este tipo que se realizaba en España, aunque también tuvo el pesado hándicap de haber sido impulsada y llevada a cabo durante el franquismo, con unas evidentes inquietudes políticas (Zárraga, 2015: 16). No obstante, contó con un buen equipo de colaboradores, algunos de los cuales serían más tarde sociólogos destacados, lo que le confirió un indudable rigor científico ${ }^{56}$. Se aunaron, pues, en ella el interés político y la inquietud sociológica por conocer la realidad de la juventud española del mo-

\footnotetext{
comienzos de la década de los 50 se había realizado una encuesta a los jóvenes universitarios, a la que siguió once años más tarde, en 1963, una segunda encuesta.

56 La encuesta de Juventud de 1960 fue organizada desde la dirección de la Delegación Nacional de Juventudes. Coordinada por el profesor José Mariano López Cepero, contó con una serie de colaboradores que después serían figuras destacadas de la sociología española. Entre ellos cabe destacar a José Castillo, Luís González Seara, Juan J. Liz, Amando de Miguel, entre otros (Zárraga, 2015: 16).
} 
mento (Vallés, 2000: 127). A partir de esta encuesta se publicaron posteriormente dos libros, entre los que cabe destacar el de Cecilio de Lora (De Lora, 1965).

La encuesta de 1960 fue realizada a un grupo de jóvenes de entre 16 y 21 años pertenecientes a 3 sectores: estudiantes, trabajadores y campesinos ${ }^{57}$. Con todas sus virtudes y limitaciones es el primer estudio que permite conocer los valores y las inquietudes de los jóvenes españoles del momento ante una serie de cuestiones, entre ellas las relativas a la familia (Vallés, 2000: 124).

La formación de una familia precisamente, junto con el servicio militar y la integración en el mercado del trabajo, eran las principales vías de incorporación de los jóvenes a la edad adulta, tal como lo evidenciaban sus aspiraciones (De Miguel, 2000: 22; De Lora, 1965: 169).

La mayoría de los jóvenes de esta generación pertenecían a ámbitos familiares aún muy tradicionales, con estructuras jerárquicas, autoritarias y patriarcales (Campo, 1982: 134 y ss). Sus valores y actitudes eran, pues, en buena medida los de sus padres (De Lora, 1965: 63 y ss; 119 y ss). Situación que no parece muy diferente a la existente en Portugal (Figueredo et al, 1999: 51-96).

Este carácter jerárquico y autoritario de la familia, así como la continuidad de muchos de sus valores, se ponía de manifiesto en el hecho de que los jóvenes demandaban a sus familias una mayor libertad de conducta antes que de pensamiento (Velarde, 1994: 107). De esa forma, la gran mayoría de ellos estaba bastante conforme con sus padres en materia religiosa y moral, así como en el "modo de gobernar la familia"; y asimismo, más de la mitad valoraba como principales cualidades de la "novia ideal" que fuese "amante del hogar y de los niños" (De Lora, 1965: 65-139).

Esta dimensión reproductiva de la familia en el terreno ideológico y moral se extendía también al campo de los estudios. Así, la mayor parte de los estudiantes encuestados $(95 \%)$ estaba conforme con sus padres respecto a la elección de sus futuras carreras, siendo muy pocos los que manifestaban indiferencia y disconformidad (3\% y 6\% respectivamente) (De Lora, 1965: 69). En una sociedad todavía tradicional, eran pocos los que albergaban el sueño del ascenso social, pues sólo una muy pequeña minoría aspiraba a cambiar y ascender socialmente, mientras que la mayoría lo que pretendía realmente era situarse y casarse, en el caso de los estudiantes, o tener un trabajo y casarse en el de los campesinos y trabajadores; un trabajo que se idenificaba sobre todo con el oficio. Por lo demás, se confiaba

La encuesta se pasó a una muestra de jóvenes de entre 16 y 20 años; concretamente 1318 varones y 421 mujeres. La razón de fijar como límite de edad los 20 años tenía que ver con el hecho de que a los 21 se incorporaban los jóvenes al servicio militar, verdadero rito de paso a la edad adulta (De Miguel, 2000: 19 y ss; Vallés, 2000: 113 y ss). 
en la "buena suerte" y en "conocer a gente influyente", dos de las cualidades consideradas más importantes para triunfar en la vida, sólo situadas por detrás de la inteligencia. En una sociedad que estaba todavía en proceso de transición hacia la modernidad industrial los valores del mérito y de la capacidad no eran aún, como se ve, demasidado apreciados (De Lora, 1965: 167 y ss).

En donde mostraban estos jóvenes una mayor discrepancia con sus padres (cercana al 50\%) era en lo relativo a "diversiones" (De Lora, 1965: 65 y ss). Pasadas las penurias de la postguerra, las nuevas generaciones demandaban un tiempo de descanso y recreo al que sus padres ni siquiera podían aspirar. Pero en el ámbito de las orientaciones ideológicas y morales la cercanía con ellos era, tal como se ha visto, todavía muy grande. Por eso, apenas superaba el 10\% el porcentaje de los que decían no pensar igual que sus familias, mientras que el $50 \%(60 \%$, en el caso de los estudiantes) relacionaban la falta de entendimiento con el hecho de querer divertirse más (De Lora, 1965: 67).

8 años más tarde, la II encuesta de Juventud, realizada por el Instituto de la Juventud en $1968^{58}$, arrojaba unos resultados que no diferían mucho de los de 1960. En efecto, los hijos manifestaban pocas discrepancias con sus padres en el terreno ideológico y moral, valorando sobre todo del padre el espíritu de trabajo, y de la madre el sentido hogareño y el cariño de sus hijos. Es decir, los jóvenes reproducían en general los valores de la familia conyugal tradicional basada en la división del trabajo, con poco interés por otros aspectos, como la comunicación- apenas mencionada por el 6\%-, más propios de una orientación postmaterialista, ajena por completo a las aspiraciones de esta generación de jóvenes (González-Anleo, 1981: 54). Generación que participaba así de un tipo de cultura que la antropóloga Margaret Mead denominó postfigurativa, porque en ella el patrón a seguir es el que marcan los mayores (Mead, 1971: 35).

Las discrepancias entre padres e hijos parecían relacionarse más con la demanda de una mayor libertad de acción que con las ideas, en donde eran más las coincidencias que las diferencias. Este entendimiento intergeneracional semejaba estar presente también en el ámbito educativo, en donde los hijos manifestaban que sus futuras elecciones en este campo no eran contrarias a las preferencias de sus padres.

Este escenario familiar comenzará a cambiar, como luego se verá, a partir de mediados de los años 70, momento en el que irán apareciendo unos valores y unas actitudes juveniles típicamente modernas.

\footnotetext{
La encuesta Nacional de Juventud de 1968 fue realizada por el Instituto Nacional de la Juventud en ese mismo año a una muestra de Jóvenes de entre 15 y 29 años, bajo la dirección de Juan Diez Nicolás y Salustiano del Campo.
} 
Cuadro 1. Familia jerárquica y reproductiva: años 60

\begin{tabular}{|c|c|c|}
\hline & PADRES & HIJOS \\
\hline 螎 & $\begin{array}{l}\text { Reproductivas, jerárquicas y disciplina- } \\
\text { rias. Basadas en el sacrificio y la poster- } \\
\text { gación de la gratificación. Hombre "gana- } \\
\text { panes"; mujer dedicada al cuidado y a la } \\
\text { educación de los hijos. } \\
\text { Favorables a la tradición. }\end{array}$ & $\begin{array}{l}\text { Reproductivas: trabajar para una ma- } \\
\text { yoría. Para una minoría, terminar los } \\
\text { estudios, siguiendo el consejo pater- } \\
\text { no, situarse y formar una familia. } \\
\text { Favorables a la tradición con una } \\
\text { cierta apertura al futuro. }\end{array}$ \\
\hline 留 & $\begin{array}{l}\text { Reproductivos, patriarcales, jerárquicos y } \\
\text { autoritarios. } \\
\text { Vinculados a la tradición. }\end{array}$ & $\begin{array}{l}\text { Reproductivos, patriarcales, jerár- } \\
\text { quicos y autoritarios. } \\
\text { Vinculados a la tradición, con una tí- } \\
\text { mida apertura al futuro. }\end{array}$ \\
\hline
\end{tabular}

\subsubsection{La transición a la familia postmoderna (1975-85). Distancia ideológica y normativa, proximidad afectiva}

En este periodo se observa un cambio en las actitudes y en los valores de los jóvenes, cada vez más distanciados de los de sus padres. Cambio que tenía lugar en un contexto familiar en el que todavía imperaba la división sexual del trabajo, con el marido como ganador de pan y la mujer como cuidadora y educadora de la prole (González-Anleo, 1984: 83).

Ambas generaciones de jóvenes- la de comienzos de los 60 y la de la década que ahora se analiza- siguen considerando a la familia como uno de los aspectos más importantes de sus vidas (González-Anleo, 1984: 91). Aumentan, sin embargo, como antes se ha dicho, las diferencias entre padres e hijos en el terreno de las ideas. Así lo ponía de manifiesto la III encuesta Nacional de la Juventud de 1975, en la que algo más de la mitad de los jóvenes entrevistados (el 51\%) afirmaba tener ideas diferentes a las de sus padres (Injuve, 1975: 22). Estas diferencias se reducían, no obstante, en las esferas más conductuales. Perdían así importancia aquellas dimensiones conflictivas más relacionadas con una mayor libertad para el ocio y la diversión, reclamada sobre todo por los jóvenes de comienzos de los 60, y que ahora pedían con bastante menos insistencia los de mediados de los 70 (González-Anleo, 1984: 91). Aumentaba sin embargo exponencialmente el porcentaje de jóvenes que contestaban afirmativamente a la pregunta "mi forma de pensar no es compatible con mi familia”. Eran menos del 10\% en 1960, eleván- 
dose este porcentaje a la mitad a mediados de los años $70^{59}$ (Velarde, 1994: 107; González-Anleo, 1984: 90; Injuve, 1975: 22).

Como prueba de esta discrepancia de pareceres entre jóvenes y adultos, los jóvenes de mediados de los años 70 manifestaban un mayor rechazo a la autoridad que los de comienzos de los 60 (González-Anleo, 1984: 91). Y los adultos encuestados en 1979 creían mayoritariamente, sobre todo los que tenían más de 35 años, socializados fundamentalmente en los valores más tradicionales, que había poca disciplina en la familia (González-Anleo, 1981: 116). Lo que quizás demostrase que el desencuentro entre ambas generaciones se debiese al contraste entre unas estructuras familiares todavía poco abiertas y participativas, con padres socializados en los valores tradicionales, y una juventud que reclamaba más poder de decisión e influencia en la familia. Así parecía ponerlo de manifiesto la citada encuesta de 1979, en la que una mayoría de jóvenes declaraba que el modelo imperante en su casa era el patriarcal (González-Anleo, 1981: 122-123). En esta misma dirección, las encuestas de 1975 y de $1982^{60}$ reflejaban una importante divergencia entre la "influencia real y la deseada" de los jóvenes en las decisiones de su familia. No obstante, esta discrepancia iba disminuyendo con el paso del tiempo, en respuesta, quizás, a una mayor apertura de los entornos familiares (Andrés Orizo, 1985: 93). Aperturismo que era mayor en las familias de clase media y media-alta que en las de clase baja, en las que se dejaba sentir más el modelo autoritario, tal como lo reflejaba la encuesta de 1979 (González-Anleo, 1981: 120-121). No obstante, la tendencia era clara, y así parecían confirmarlo las encuestas de juventud de 1981 y $1984^{61}$, en las que emergían unas relaciones paterno-filiales más permisivas y menos conflictivas (Andrés Orizo, 1985: 128 y 1983: 300).

Esta menor conflictividad se conjugaba sin embargo con un crecimiento del disenso en el campo normativo y de los valores. Todo lo cual indicaría que la familia estaba perdiendo relevancia como institución transmisora de normas, sobre todo en el terreno religioso y moral. Aunque esta situación era menos acusada en

59 Los datos proceden de la encuesta de 1975, realizada por el Instituto de la Juventud a una muestra de 3500 jóvenes de entre 15 y 25 años.

60 La encuesta de 1975 se integra en la III encuesta Nacional de Juventud realizada a una muestra de 3414 jóvenes de ambos sexos, comprendidos entre los 15 y los 25 años de edad (Injuve, 1975). La de 1982 fue realizada bajo la dirección de la Dirección General de la Juventud y el CIS a una muestra de 3654 jóvenes, de entre 15 y 20 años, siendo coordinada por Manuel García Ferrando y José Juan Toharia.

${ }^{61}$ La encuesta de 1981 fue coordinada por J.J Linz y Andrés Orizo, en el marco del proyecto europeo del European Value Systems, y realizada en la primavera de ese año a un grupo 2306 jóvenes de entre 18 y 24 años. Los datos de la encuesta comentados están contenidos en (Andrés Orizo, 1983). La encuesta de Juventud de 1984 fue patrocinada por la Fundación Santa María y realizada a una muestra de 3343 jóvenes de ambos sexos comprendidos entre los 15 y los 24 años (Andrés Orizo, 1985). 
las clases altas y medias-altas que en el resto de los estratos sociales, manifestando una mayor tendencia a la reproducción social en los grupos sociales más elevados (Andrés Orizo, 1985: 131 y ss; 300 y ss.).

No obstante, en general, el modelo reproductivo parecía erosionarse gradualmente, también en ámbitos como el académico, en donde el 70\% de los jóvenes declaraban en 1977 "que ellos mismos eligieron personalmente sus estudios" (González-Anleo, 1981: 123). Aun así, esta erosión, acompañada del deseo de independencia y de liberación de los hijos con respecto a los valores de sus padres, se conjugaba con una mayor voluntad de aquellos, con relación a sus homónimos de la etapa anterior, de integrarse para progresar en los escalones meritocráticos de las instituciones educativas y laborales (Martín Escudero, 1994: 146; García Ferrando, 1984b: 65 y ss). Un deseo, que en el caso de los hijos de las clases medias-altas y altas se proyectaba relativamente más sobre el ámbito educativo, como camino para lograr una inserción laboral exitosa, y en el de las demás clases, sobre todo de las bajas, más sobre el ámbito laboral (Beltrán, 1984: 200-201). Dicho de otro modo, la voluntad de independencia y de liberación de los hijos, que en el ámbito familiar se manifestaba en el rechazo a los valores de sus padres, iba acompañada de la voluntad de integración en los órdenes meritocráticos escolares y laborales, para lograr así la independencia y la libertad ansiadas. Porque sin esa integración no había reconocimiento, y sin él tampoco la posibilidad de independizarse y de liberarse. Ahora bien, para una cosa y para la otra ya no había que seguir el camino trazado por los progenitores, sino abrirse uno nuevo, aunque respetando, eso sí, las etapas y las normas fijadas institucionalmente.

Todo ello se traducía en una diferente representación del tiempo de padres e hijos. En efecto, mientras que los primeros contaban con las experiencias y las vivencias del pasado, a través de las cuales apreciaban las mejoras del presente, proyectándolas hacia el futuro; los segundos tenían las vivencias de un presente de mayor prosperidad y esperanza, que trasladaban hacia el futuro, rechazando el pasado. Y ahí precisamente radicaba el desencuentro, no solamente en los valores que los progenitores arrastraban del pasado y que sus hijos rechazaban, sino también en el sentido que cada generación atribuía a sus respectivos sacrificios. Frente a la ética sacrificial de los padres se abría así, poco a poco, las actitudes y los valores más hedonistas de los hijos. Aunque por el momento, también ellos tenían que someterse a una cierta disciplina ética para superar sus condicionamientos de partida.

Esta situación de discrepancia entre padres e hijos en el plano normativo y de los valores, con la consiguiente erosión de los patrones reproductivos familiares, por una parte. Y la mayor cercanía en el ámbito sentimental y afectivo, acompañada del deseo de integración de los hijos en los órdenes meritocráticos de la educa- 
ción y del trabajo, por la otra, iba a cambiar gradualmente a partir de mediados de los años 80. Desde ese momento, en efecto, se iba a ir acortando la distancia entre unos y otros en el campo ideológico y de los valores, al tiempo que los hijos manifestarán una menor voluntad de integración en los ámbitos meritocráticos de la educación y del trabajo. Todo lo cual tendrá una clara influencia en los procesos de socialización y de transmisión, así como en las formas de reconocimiento.

Cuadro 2. Familia de transición: 1975-85

\begin{tabular}{|c|c|c|}
\hline & PADRES & HIJOS \\
\hline 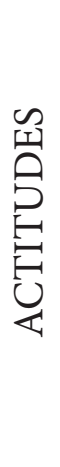 & $\begin{array}{l}\text { Distancia ideológica y normativa con } \\
\text { respecto a los hijos. Actitudes disci- } \\
\text { plinarias, jerárquicas y patriarcales, y } \\
\text { menos reproductivas. } \\
\text { Favorables más a la integración que a la } \\
\text { liberación. } \\
\text { Progresar, superando el pasado sin } \\
\text { rechazarlo. }\end{array}$ & $\begin{array}{l}\text { Distancia ideológica y normativa } \\
\text { con respecto a los padres. Actitu- } \\
\text { des, democráticas, individualistas y } \\
\text { meritocráticas. } \\
\text { Favorables a la liberación sin opo- } \\
\text { nerse a la integración. } \\
\text { Orientadas hacia el futuro con } \\
\text { rechazo del pasado. }\end{array}$ \\
\hline 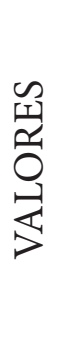 & $\begin{array}{l}\text { Disciplinarios, jerárquicos y } \\
\text { sacrificiales. } \\
\text { Futuristas, con deseo de superar, más } \\
\text { que de rechazar el pasado. }\end{array}$ & $\begin{array}{l}\text { Crecientemente democráticos, } \\
\text { igualitaristas individualistas y } \\
\text { meritocráticos. } \\
\text { Moderadamente sacrificiales y } \\
\text { hedonistas. Futuristas, con rechazo } \\
\text { del pasado }\end{array}$ \\
\hline
\end{tabular}

\subsubsection{De la familia transmisora a la convivencial}

A partir de mediados de los años 80 se van reduciendo gradualmente las diferencias entre padres e hijos en el terreno de las creencias y de los valores, acentuándose esta tendencia a partir de finales de la citada década (Toharia, 1989: 209). Así, en los años 90 se habla ya de consenso normativo (Andrés Orizo, 2001: 154-155), o de solidaridad consensual (González-Anleo, 1999: 148). Situación que se mantiene comenzado el nuevo siglo (Ayuso, 2010: 136; Megías, 2003: 33; Campo y Rodríguez, 2002: 149).

Este panorama no difiere mucho del que ha sido descrito para Portugal. En efecto, aquí también, fundamentalmente a partir de los años 90, la familia se hace más democrática, consensual y flexible (Pais, 1998: 378), acomodándose a los patrones dominantes en las sociedades postmodernas. 
Estaríamos asistiendo así a un acercamiento progresivo de las actitudes y de las mentalidades de padres e hijos, en correspondencia con unos padres socializados en su juventud en valores más igualitarios y permisivos (Meil, 2006: 38; Moreno, 2002: 10; González-Anleo, 1999: 150; Velarde, 1994: 108 y ss; Toharia, 1989: 209 y ss).

Observemos este hecho con más detenimiento. Según los Informes de Juventud de 1984 y 1989 de la Fundación SM, las cualidades más importantes que los jóvenes, entre 15 y 29 años, consideraban necesario desarrollar en los niños en casa eran los "buenos modales", el "sentido de la responsabilidad", la "honestidad" y la "tolerancia". Gozaban sin embargo de poco predicamento, situándose en los últimos lugares de la lista, virtudes tales como la "paciencia", la "determinación", la "perseverancia", el "sentido del mando" o la "abnegación", cualidad, esta última, que era la menos apreciada por los jóvenes (Toharia, 1989: 218).

Desde la perspectiva de los padres, la situación no era muy diferente. En efecto, según las encuestas del CIS de 1994, el conjunto de valores que los padres menores de 65 años consideraban necesario transmitir a sus hijos en casa, se ordenaba de tal manera que la "honradez" y los "buenos modales", el "sentido de la responsabilidad", la "tolerancia" y el "respeto a los demás" se situaban en los tres primeros lugares, mientras que la "determinación" y la "perseverancia" ocupaban el penúltimo lugar, y la "abnegación” el último ${ }^{62}$ (Andrés Orizo, 2001: 158-159). Situación que no era muy diferente a la reflejada unos años más tarde- en el periodo 1999/2000- por la EVS (Encuesta Social de Valores) (Meil, 2006: 126).

No obstante, dentro de este panorama general cabe destacar lo siguiente. Los padres comprendidos entre los 35 y los 44 años de edad, que en su juventud, durante los primeros años 80 , habían sido socializados en normas y actitudes más liberales, situaban en primer lugar los valores de la "tolerancia" y la "responsabilidad", mientras que los mayores, vinculados a una cultura más jerárquica y normativa, daban más preeminencia a valores tales como los "buenos modales", la "fe religiosa", el "espíritu de ahorro", la "disposición a trabajar duro" y la "obediencia" (Andrés Orizo, 2001: 162).

Con respecto a este último aspecto, el de la "autoridad" y la "obediencia", se advertía también una mayor proximidad entre las generaciones de jóvenes y de adultos. En general, estos valores eran poco apreciados por ambas generaciones. En efecto, los jóvenes de entre 15 y 29 años se adherían poco al valor de la "obediencia”, puesto que el 69\% de ellos se inclinaba, tanto en 1999 como en 2005, por

62 Con respecto a las transmisiones, cabe decir que una cosa es lo que los padres desean transmitir, y otra que efectivamente lo transmitan. No obstante, el mero hecho de considerar algo como deseable aporta ya información acerca de lo que una determinada sociedad valora especialmente en relación con la educación de los hijos (Meil, 2006: 88). 
relaciones familiares más democráticas y permisivas. Mientras que sólo una minoría, el 12\% de los encuestados en 1999 y el 10\% en 2005, defendían relaciones más autoritarias (González-Blasco, 2005: 214). Con respecto a los padres, los situados entre los 35 y los 44 años de edad, socializados en su juventud en valores más democráticos y participativos, apenas consideraban la "disciplina" como un valor importante que transmitir a la próxima generación (Pérez Díaz, 2001: 139).

En este escenario familiar, así descrito, se irán imponiendo, por tanto, progresivamente unas relaciones más democráticas, participativas y negociadoras, más basadas en convencer, que en mandar y obedecer (Ayuso, 2010: 142-143). Todo lo cual indicaba que los valores jerárquicos, así como los más vinculados al sacrificio y a la postergación de la gratificación, relacionados con el modelo meritocrático, estaban cada vez más erosionados en los ámbitos familiares, mientras que aquellos otros más vinculados con los principios democráticos de tolerancia, persuasión y respeto estaban bien asentados, tanto entre los padres como entre los hijos (González-Blasco, 2005: 211 y ss). Ambas generaciones, de padres y de hijos, compartían así cada vez más unos mismos valores, más focalizados en la tolerancia y el respeto que en la determinación y el sacrificio.

De este modo, las tensiones que en otro tiempo nacían de las discrepancias generacionales en el contexto de una familia con más vocación normativa y transmisora, se disolvían ahora en un ambiente familiar mucho más comprensivo, negociador, tolerante y afectivo (Ayuso, 2010: 142; Meil, 2006: 42-43; González-Blasco, 2005: 213; Andrés Orizo, 2001: 330; González-Anleo, 1999: 132); más orientado a la convivencia que a las transmisiones.

Los conflictos que en estas circunstancias podían surgir estaban más asociados a los controles instrumentales vinculados a la convivencia (rendimiento escolar, horas de llegada a casa después de salir con los amigos, colaboración en las tareas domésticas), que con aquellos otros aspectos ligados al mundo de las ideas y de los valores, apenas mencionados por una minoría de padres (ideología política y creencias religiosas, gustos y estilos de vida, amistades) (Ayuso, 2010: 140; Meil, 2006: 143 y 1999: 170; González-Blasco, 2005: 218-219; Megías, 2003: 55; González-Anleo, 1999: 138-139; Del Valle, 1994: 104-105).

Todo ello ponía, quizás, de manifiesto cierta tensión entre las dos metas de la socialización familiar. Por una parte, la necesidad de ejercer un cierto control normativo y disciplinario sobre los hijos, con vistas a su desarrollo personal y a su éxito académico; por la otra, el deseo de ser afectuoso con ellos, de respetarlos y de comprenderlos, no generando demasiadas tensiones (Singly, 2016: 147 y ss). Como esta segunda dimensión, más tolerante, convivencial e individualista, es la que se impone crecientemente, los controles se hacen más instrumentales que nor- 
mativos; menos basados en el convencimiento y la determinación que en una débil aspiración.

En este contexto familiar no hay por tanto grandes fuentes de conflictos. Las convergencias intergeneracionales en el ámbito de las ideas y de los valores, y el ánimo de excluir estos asuntos del ámbito de la discusión, dentro de una familia más orientada a la convivencia que a las transmisiones, explican esta situación (Ayuso, 2010: 141; González-Blasco, 2005: 209; González-Anleo, 1999: 143-144). Se habla mucho, sí, pero de temas más cotidianos, en un ambiente abierto y participativo. Acaso por esta razón el 83\% de los jóvenes valorasen en 2005 tan positivamente la comunicación dentro de la familia (González-Blasco, 2005: 210).

Dentro de este panorama común, son los jóvenes de clase alta y media-alta los que más discuten con sus padres por temas de rendimiento escolar, descendiendo este porcentaje a medida que lo hace la clase social (González-Blasco, 2005: 219; González-Anleo, 1999: 141), mostrando, quizás, una mayor conciencia de las expectativas académicas en los miembros de las clases más favorecidas (Jurado y Echaves, 2016: 103-104; Singly, 2016: 151-152).

En este escenario familiar, democrático y consensual, dominado por la cercanía y los afectos, no resulta extraño que la familia aparezca como la institución más valorada por los jóvenes, tal como corroboran las distintas encuestas desde hace ya más de dos décadas (Toharia, 1989; CIS, 1994; Meil, 1999; Alberdi, 1999; Gonzalez-Anleo, 1999; Andrés Orizo, 2001; Moreno, 2002; Megías, 2003; González-Blasco, 2005; Ayuso, 2010). Valoración que compartía también la juventud portuguesa (Figueiredo et al, 1999). En la familia se reciben, en efecto, los refuerzos afectivos y emocionales, y también el apoyo material, sin cargar por ello con los costes de los controles y de las imposiciones de otras épocas (González-Blasco, 2005: 208; Moreno, 2002: 4). Por este motivo, acaso, los jóvenes opinen en casi todas las encuestas que es allí, en la familia, en donde se dicen las cosas más importantes, mucho más que en la escuela (Elzo, 2004: 206-207).

Esta apreciación de la familia como un espacio de apoyo emocional y material, dentro de unas estructuras abiertas al diálogo y a la negociación, comenzaba también a observarse en Portugal a partir de mediados de los años 80 (ICS, 1987). En efecto, también en este país se percibe una solidaridad consensual entre las generaciones ${ }^{63}$, en el marco de unas relaciones paterno- filiales más democráticas y flexibles, reguladas por el principio de la negociación entre iguales (Pais, 1998: 371 y ss; ICS, 1987). Así se comprende que una amplia mayoría de encuestados refiera

63 A pesar de que los lazos familiares son ahora mucho más horizontales que verticales, más afectivos que rígidos, parece advertirse en las conciencias portuguesas una fuerte interiorización normativa del sentido de la solidaridad, sin que ello ponga en cuestión la autonomía individual, tan valorada en las sociedades modernas. 
que nunca le ha dado motivo de castigo a sus padres (ICS, 1998). Siendo los grupos familiares menos conservadores y tradicionales los que más mencionan las formas de castigo no físicas, lo que pondría de manifiesto que en estos grupos es en los que más predomina la tendencia a la negociación familiar.

Si descendemos a un nivel más concreto, podemos comprobar que los portugueses asumen posiciones próximas a los españoles, tal como muestran los datos del EVS- European Values Survey- relativos a los años 1990 y 2008. Estos datos evidencian esa aproximación progresiva de las mentalidades de padres e hijos, ya que tanto la generación más joven, de 15 a 29 años, como la más madura, de 30 a 49 años, así como la de 50 años en adelante, aprecian las mismas cualidades educativas. Veamos: en 1990 los portugueses pertenecientes a los diferentes grupos de edad manifiestan que "tener buenas maneras", "ser responsable" y "ser tolerante y respetuoso", son los valores educativos más importantes; si bien los más jóvenes ordenan estas prioridades de manera diferente, al considerar que "ser responsable" es la cualidad más importante de las tres, seguida de "tener buenas maneras" y "ser tolerante y respetuoso". Los datos de 2008 corroboran esta tendencia de consenso normativo intergeneracional, ya que los valores mencionados como más importantes se mantienen iguales a los de 1990 . No obstante, hay una ligera diferencia entre los valores que presentaban en 1990 y en 2008 la generación de 30 a 49 años. Así, mientras que en 1990 destacaban las "buenas maneras" como un elemento esencial en la educación de los hijos, en 2008 los valores más importantes eran "ser responsable" y "tener tolerancia y respeto". Asimismo, en 2008, cobra una mayor relevancia el valor "trabajar duro", que en 1990 se situaba en el cuarto puesto de los valores más apreciados, mientras que ahora aparece en el tercero.

Es importante destacar que la generación portuguesa más joven atribuyó menos importancia a la "fe religiosa" como valor central en la educación de la juventud, tanto en 1990 como en 2008. Este valor iba siendo más apreciado, sin embargo, a medida que avanzaba la edad. Así, en la generación de más de 50 años, tanto en 1990 como en 2008, el valor menos importante es "no ser egoísta".

Si hacemos ahora un análisis de la priorización de los valores en la educación de los más jóvenes en España, nos encontramos con un escenario bastante similar al de Portugal. De este modo, en 1990 y en 2008, los españoles y los portugueses, independientemente del grupo de edad, posicionan como valores más importantes el "ser responsable", "tener buenas maneras" y "ser tolerante y respetuoso", aunque el orden atribuido a dichos valores en cada grupo de edad sea ligeramente diferente. Todo ello pone de manifiesto que la priorización de los valores de los portugueses es similar a la de los españoles, pues ambos los jerarquizan de forma análoga. Asimismo, en ambos países, tanto en 1990 como en 2008, tienen un ca- 
rácter secundario para todos los grupos de edad valores tales como "determinación y perseverancia", "obediencia", "sentido del ahorro" y "fe religiosa".

Los datos relativos al EVS evidencian, pues, tal como se ha visto, la tendencia ya referida, en el sentido de una visión cada vez más compartida entre las distintas generaciones de padres e hijos. En efecto, ambas generaciones manifiestan una orientación similar en relación a la educación de los más jóvenes, en una dirección bastante parecida a lo que ocurre en la mayoría de las sociedades occidentales. De este modo, mientras que los valores jerárquicos y los vinculados al esfuerzo y a la postergación de la gratificación en general pierden importancia, aquellos otros más relacionados con los comportamientos cívicos, con un carácter más individualista y menos jerárquico, la ganan. Todos estos valores se inscriben, como se ha dicho, en una familia más abierta al diálogo y a la negociación, y más orientada al desarrollo personal y a la felicidad de sus miembros más jóvenes, con la intención de llevar al máximo todas sus potencialidades (Singly, 2007: 97-98).

En este contexto, se produce una cierta tensión entre dos de las metas más importantes a las que se orienta la educación de los hijos; a saber, por una parte, la vinculada a los valores más expresivos de la tolerancia, la comunicación y el respeto; por la otra, la relacionada con los principios meritocráticos (Singly, 2016: 232; Elzo, 2004; Megías, 2003). Si la primera de estas metas implica el deseo de ser reconocido a partir de las dimensiones más subjetivas, expresivas y liberadoras, y por tanto también más autorrerferenciales, que se orientan sobre todo al corto plazo; la segunda requiere conjugar estas dimensiones con aquellas otras más integradoras e institucionales, vinculadas al logro, que sólo pueden ser realizadas en el largo plazo. Una tensión que se resuelve muchas veces con la meritocracia del corto plazo, consistente en otorgar diplomas apenas se han concluido las primeras etapas del ciclo escolar. No obstante, cuando en posteriores etapas surgen obstáculos que dificultan la consecución de los logros pretendidos, aparecen de nuevo las tensiones entre la vertiente meritocrática y la expresiva (Elzo, 2004; Megías, 2003). Si los padres, consideran, en efecto, que su deber es "procurar lo mejor para sus hijos, aun a costa de su propio bienestar", tal como creía el 83\% de los encuestados menores de 50 años a comienzos del nuevo siglo (Meil, 2006: 139), y si consideran, asimismo, que una de las dimensiones del éxito de sus hijos es la académica, es más fácil comprender por qué no aceptan sus malos resultados, interpretados no sólo como un fracaso de los hijos, sino también de los propios padres. Se hace imprescindible, pues, encontrar una explicación a una situación que frustra sus expectativas, dirigiendo la mirada hacia las instituciones académicas.

Por lo que respecta a los hijos, cargados como están con la razón personal en la que han sido socializados, se muestran cada vez más renuentes a aceptar las reglas institucionales. Quizás por este motivo una buena parte de ellos (el 41\%) 
se mostrase bastante crítico con aquellos aspectos más normativos y disciplinarios de las instituciones académicas (González-Anleo, 1999: 170). Y fuesen, por el contrario, mucho más favorables hacia aquellos otros aspectos más relacionados con la convivencia entre iguales. De este modo, mientras que un número bastante apreciable de los estudiantes encuestados en 1999 estaba "poco o nada satisfecho" con los profesores (el 34,1\%) y con los métodos de enseñanza (36,3\%), una inmensa mayoría de ellos (el 92,7\%) estaban "muy o bastante satisfechos" con la relación con sus pares (González-Anleo, 1999: 167). En suma, la cultura individualista e igualitarista, afectiva y convivencial, se imponía sobre todos aquellos aspectos institucionales que reprimían algunas de las manifestaciones de la personalidad.

Cuadro 3.

Familia democrática y convivencial (a partir de mediados de los años 80 ).

\begin{tabular}{|c|c|c|}
\hline & PADRES & HIJOS \\
\hline 量 & $\begin{array}{l}\text { Democráticas, participativas, persuasivas, } \\
\text { negociadoras y afectivas. Basadas en la pro- } \\
\text { moción y en la realización personal de los } \\
\text { hijos. }\end{array}$ & $\begin{array}{l}\text { Democráticas, consensuales, indi- } \\
\text { vidualistas y afectivas. }\end{array}$ \\
\hline 语 & $\begin{array}{l}\text { Relevancia de los valores cívicos (honradez, } \\
\text { buenos modales, sentido de la responsabilidad, } \\
\text { tolerancia, respeto a los demás) y de los basa- } \\
\text { dos en el cariño y el afecto. Pérdida de impor- } \\
\text { tancia de los valores sacrificiales y jerárquicos } \\
\text { (determinación, perseverancia, abnegación, } \\
\text { obediencia). } \\
\text { Tensión entre los valores subjetivos y expresi- } \\
\text { vos, cortoplacistas, y los institucionales meri- } \\
\text { tocráticos de largo plazo. }\end{array}$ & $\begin{array}{l}\text { Fuerte apreciación de la familia. } \\
\text { Predominio de los valores cívi- } \\
\text { cos (buenos modales, sentido de } \\
\text { la responsabilidad, honestidad, } \\
\text { tolerancia), de los basados en la } \\
\text { autonomía y la realización perso- } \\
\text { nal, y de los afectivos. Relegación } \\
\text { de los vinculados al sacrificio y a } \\
\text { la postergación de la gratificación, } \\
\text { y también a la obediencia. }\end{array}$ \\
\hline
\end{tabular}

\section{Conclusión}

A lo largo de este capítulo se ha descrito el cambio de las actitudes y de los valores de padres e hijos, españoles y portugueses, en el marco del proceso de modernización y postmodernización de la familia occidental, con el objetivo de mostrar la influencia que dicho cambio ha tenido en los procesos de socialización y de transmisión de normas y de valores entre generaciones, y también en los modos de concebir la educación, tanto por parte de los padres como de los hijos. 
Para ello se han diferenciado tres periodos que señalarían este proceso; a saber, el correspondiente a la década de los años 60, el comprendido entre 1975-85 y el posterior a esta última fecha. Cada uno de estos periodos ha sido caracterizado con alguno de los siguientes adjetivos que lo definiría; a saber: familia reproductora en los años 60, del disenso normativo e ideológico en la década 1975-85, y la convivencial a partir de esta última fecha hasta el presente.

Tanto la familia de los años 60 como la actual se caracterizarían por una importante proximidad de las actitudes y de los valores de padres e hijos. Proximidad que obedecería sin embargo a causas bien distintas. En el primer caso, son los jóvenes quienes reproducen muchos de los valores de los adultos; en el segundo son los adultos, por el contrario, los que comparten muchos de los valores y de las actitudes de los más jóvenes, al haber sido socializados en su juventud en nomas y en valores no muy diferentes a los de sus descendientes. Entre estos dos modelos familiares, el de la década 1975-85 marcaría la distancia entre el mundo más denso, jerárquico y normativo de los adultos y el más liviano, democrático e individualista de los jóvenes. Distancia que se expresaría en la oposición más o menos conflictiva de los valores y de las actitudes de unos y de otros. No obstante, el rechazo que manifestaban los jóvenes a las estructuras disciplinarias y autoritarias de la familia iba acompañado de la pretensión de integración en las estructuras meritocráticas del mundo de la educación y del trabajo, con la intención de lograr un determinado reconocimiento que posibilitase una cierta liberación y autonomía. Todo lo cual presuponía la aceptación de normas jerárquicas y de un cierto espíritu de sacrificio.

Esta oposición dará lugar, en el modelo familiar posterior, el que se inaugura a partir de mediados de los años 80, a un consenso normativo. Un consenso entre padres e hijos que es más el fruto del acuerdo en torno a valores blandos (Elzo; Castiñeira, 2012), vinculados a una convivencia familiar democrática e individualista, que de la transmisión de normas densas, jerárquicas e institucionales, que fijen metas sociales para el individuo. Metas que presuponen la adopción de algún tipo de "disciplina ética" (Sennett, 2001: 20), en virtud de la cual se supedite la conducta propia a principios que la trascienden.

En este contexto familiar los controles se tornan por ello cada vez más instrumentales. Instrumentales, porque se basan más en el deseo de realización personal de los hijos, que en su integración en un determinado orden normativo y disciplinario. Por ello, se quiere convencer, más que obligar a quienes de algún modo están en el mismo plano normativo. Desde este punto de vista, hay una clara ruptura con respecto a los padres de las generaciones precedentes, que actuaban y hablaban en nombre de principios éticos y normativos que habían recibido e integrado 
en sus experiencias, y por los que se sentían autorizados a educar a sus hijos, sin necesidad de convencerlos de lo que en principio tenían que estar ya convencidos.

Convencidos estaban, en efecto, los jóvenes de las familias de los años 60 de que tenían que respetar la autoridad, sobre todo la del padre, porque compartían la mayor parte de los valores que la encarnaban. Y seguro estaba éste de lo que tenía que transmitir a aquellos. Este convencimiento se irá perdiendo en los jóvenes de las familias del periodo 1975-85. Lo que desembocará en una progresiva distancia generacional entre unos padres que querían imponer, con cada vez menos autoridad, lo que sus hijos ya no entendían ni aceptaban.

Esta brecha generacional se irá cerrando poco a poco en la etapa siguiente, a partir de 1985. En efecto, los adultos ya no querrán trasladar a los jóvenes conductas y normas cada vez más ajenas a sus experiencias. La del esfuerzo por moverse socialmente a través del trabajo duro, dejando atrás las penurias pasadas; la de formar una familia e inculcarle este modo de entender la vida. Todo eso ha pasado; ya no es tan relevante para unos padres que han crecido en la abundancia de la segunda mitad de los años 60. Comienza a contar mucho más el afecto y la convivencia con los hijos, en un marco de igualdad y de libertad a la que siempre han aspirado sus progenitores, y al que habían opuesto en su juventud la figura autoritaria del padre, con lo que todo ello representaba. Para los padres de la década de los 90, esta oposición tendrá sin embargo cada vez menos sentido. Han pasado, en efecto, la mayor parte de su infancia y toda su juventud en un ambiente más tolerante y permisivo, que han integrado en sus experiencias para comunicar a sus hijos. La cercanía entre unos y otros se hace por ello cada vez más evidente. El consenso ha sustituido al disenso de la etapa anterior. La familia comienza a estar regida por las mismas formas democráticas que imperan en el espacio público, siendo además la base material, afectiva y sentimental para sus miembros más jóvenes, por lo que la valoran especialmente.

Ahora bien, esta valoración de la familia, en relación con las dimensiones más afectivas, individulistas y expresivas, convive también con su desvalorización como institución transmisora y socializadora, todo lo cual genera una serie de tensiones vinculadas a la educación de los hijos. Tensiones entre las dos metas a las que se orienta dicha educación. Una más individualista, expresiva y autorreferencial, basada en el reconocimiento de cada personalidad, y que se orienta más a la cotidaniedad del corto plazo. La otra más meritocrática, vinculada a la consecución de una serie de logros que han de ser reconocidos institucionalmente, a más largo plazo. Una tensión que no pocas veces acaba en conflicto, cuando aparecen obstáculos que dificultan la consecución de los logros pretendidos.

En este contexto, los jóvenes también han ido perdiendo progresivamente los valores meritocráticos vinculados a la reproducción y a la movilidad social, tradi- 
cionalmente asociados al mundo de la educación y del trabajo. En su lugar, ganan cada vez más relevancia aquellos otros relacionados con el universo del consumo, mucho más individualistas y expresivos, tal como se verá en el próximo capítulo. 


\title{
CAPÍTULO III \\ FORMAS DE VER Y DE CONSTRUIR LA JUVENTUD. DEL CAPITALISMO DE PRODUCCIÓN AL DE CONSUMO
}

\begin{abstract}
En los años sesenta, el capitalismo inauguraba la era espacial, y el "hombre organización" era una lata, no sólo como padre, sino también como directivo de una empresa. Los antiguos valores de la cautela, diferencia y jerarquía ahogaban la creatividad y frenaban la flexibilidad; no sólo cercenaban el espíritu humano, sino también el espíritu consumista y el espíritu empresarial. Cuando los líderes de la empresa echaron un vistazo a la cultura juvenil que hervía a su alrededor, vieron un reflejo de sus propias luchas contra la burocracia opresiva del pasado así como la semilla de un orden consumista nuevo y dinámico que ocuparía el lugar anterior (Frank, 2011: 63-64).
\end{abstract}

\subsection{LA EDUCACIÓN EN LA SOCIEDAD INDUSTRIAL}

La escuela emergió en el contexto de la sociedad industrial como una institución necesariamente eficiente, jerárquica y disciplinaria, en consonancia con las reglas y las normas morales que requería el mundo del trabajo asalariado (Pollard, 1987: 257 y ss). Con este carácter se irá institucionalizando a partir de la segunda mitad del siglo XIX, tanto en Europa como en América (Luzuriaga, 1994; Varela, 1991: 175 y ss; Fernández Enguita, 1990: 136; Bowen, 1985 III: 554 y ss).

No obstante, la expansión de los sistemas educativos en la mayoría de los países occidentales no se producirá hasta después de la Segunda Guerra Mundial (Prats y Reventós, 2005: 230). En efecto, en un contexto de fuerte crecimiento económico, la educación fue impulsada como uno de los principales agentes de dicho crecimiento (Ortega, 1993: 89). Y por ello también como uno de los más importantes instrumentos de la ideología moderna del logro. La jerarquía en ella imperante, con todas sus regularidades disciplinarias (Foucault, 1999), fue percibida como la contrapartida necesaria al esfuerzo que requería la lucha por el éxito académico.

Aquellos que no comulgaban con este régimen disciplinario, porque no aspiraban tampoco a futuros logros académicos, aceptaban sin embargo aquellas otras disciplinas del mundo laboral, porque conllevaban también sus recompensas. En efecto, tal como puso de manifiesto Paul Willis en su clásico estudio sobre la contracultura escolar en la Inglaterra de mediados de los años setenta (Willis, 1988), esta actitud estaba directamente relacionada con la cultura de fábrica. Suponía un rechazo de todo lo vinculado con el mundo académico, en la misma medida en que implicaba la aceptación de muchos de los valores de la cultura del trabajo. "La 
experiencia de los "colegas" en la cultura contraescolar- escribió Willis- suaviza su transición al trabajo y da lugar a apetencias que el trabajo manual satisfice adecuadamente" (1988: 129).

De este modo, aunque fuese indirectamente, la cultura escolar más que oponerse a la cultura del trabajo, la reforzaba. En efecto, aquellos jóvenes que no querían saber nada de la escuela, de sus propuestas académicas y de sus exigencias disciplinarias, aceptaban sin embargo de buen grado esas otras disciplinas laborales. "El otro lado de la actitud "ellos" y nosotros "producida informalmente por "los colegas" - afirmaba Willis- constituye una aceptación de unas relaciones de autoridad previas (...), su cultura supone un reconocimiento de, y una acomodación a, los hechos del poder y la jerarquía" (1988: 131). De esta forma, la cultura escolar y la del trabajo mantenían su coherencia, produciendo y reproduciendo sus distintas recompensas, pero también sus órdenes jerárquicos y disciplinarios. En efecto, aquellos que asumían la primera de aquellas culturas, aceptaban también sus disciplinas; los que, por el contrario, la rechazaban, admitían sin embargo la jerarquía y la autoridad de la cultura de fábrica, porque era fuente de identidad para ellos.

Esta situación era la propia de un momento en el que la cultura del trabajo todavía se mantenía viva en una buena parte de la juventud, y en el que aún era posible desarrollar dicha cultura sin las trabas del desempleo juvenil.

Toda esta realidad comenzará a cambiar, especialmente a partir de los años ochenta del siglo pasado, a medida que se incrementaban las tasas de desempleo juvenil, incluso en aquellos sectores que disponían de credenciales académicos (Artiaga et al, 2014a; Beck, 2006: 144; Serrano, 2000). En este escenario, en el que la educación relajaba cada vez más sus vínculos con el mundo del empleo, y en el que las personas que abandonaban tempranamente el sistema escolar tenían cada vez más dificultades para encontrar trabajo, empezaron a perder fuerza los valores del logro y del estatus vinculados al mundo laboral y educativo, y con ellos también las estructuras disciplinarias que regían en estos ámbitos.

En efecto, la contracultura escolar, a la que Willis se refería, parecía no encontrar ya acomodo en los valores imperantes en la cultura del trabajo. Como tampoco parecían tener el mismo sentido las normas vinculadas a las jerarquías y a las disciplinas imperantes en el mundo educativo, sobre todo cuando las recompensas se revelaban como cada vez más difusas. Todo ello ocurría en un contexto de prolongación de la edad escolar, lo que contribuía todavía más a debilitar el sentido de ambas culturas, la escolar y la del trabajo.

En este escenario la cultura del consumo, ya plenamente establecida en el mundo Occidental, al menos desde mediados del siglo pasado, cobró aún un mayor protagonismo para la juventud. Aunque este protagonismo ya había comenza- 
do a manifestarse mucho antes, en las primeras décadas del siglo XX, como se verá seguidamente.

\subsection{Del CAPITAlismo de PROdUCCIÓN AL DE CONSUMO}

La emergencia de una cultura del consumo vinculada a la infancia y a la juventud comenzó a ser visible, en efecto, en las primeras décadas del siglo XX en Norteamérica (Feixa, 2014: 146). El desarrollo de esta cultura estuvo relacionado con una percepción de la infancia y de la juventud como edades depositarias de una esencialidad sentimental y moral que había que preservar de toda mala influencia (Buckingham, 2013). Esta mentalidad era la heredera de una ideología que comenzó a penetrar en las familias burguesas a lo largo del siglo XVIII (Ariés, 1987: 528 y ss). A comienzos del siglo XX dicha ideología se tradujo en la creación de diversas leyes que prohibían el trabajo infantil, apartando a niños y a jóvenes del mundo laboral (Ramiro: 2015: 9; Ewen, 1983: 141). Esta actitud abrió la posibilidad de que la cultura del trabajo fuese gradualmente sustituida por otra nueva cultura, la del consumo. En la difusión de dicha cultura participaron activamente los industriales, que contribuyeron notablemente a propagarla. Tal como comentaba un empresario norteamericano a mediados de los años 20 del siglo pasado, "la producción en masa requería la educación de las masas” (Citado en Ewen, 1983: 66).

Sin embargo, la consolidación de la cultura del consumo no se hubiese producido sin el desarrollo de los sistemas educativos de masas, que retrasaron la incorporación de los jóvenes al mundo del trabajo, prolongando su exposición al ámbito del consumo. Un proceso que se inició primeramente en Norteamérica, en las primeras décadas del siglo XX, y posteriormente, después de la Segunda Guerra Mundial, en Europa (Bocock, 1995: 47-48).

No obstante, la incorporación gradual de la infancia y de la juventud a la esfera del consumo despertó también numerosos recelos entre aquellos que observaban con creciente preocupación la influencia perversa que esta nueva cultura consumista podría ejercer sobre niños y jóvenes, con la consiguiente pérdida de autoridad por parte de los adultos (Buckingham, 2013). Dicha preocupación no carecía de sentido, pues la industria y la publicidad se dirigían principalmente a este grupo de edad, más que a sus progenitores, reclamando su capacidad y su criterio para decidir libremente (Jacobson, 2004). Tanto publicistas como industriales estuvieron, en efecto, especialmente interesados en degradar la autoridad paterna, para otorgar así un mayor protagonismo a la infancia y a la juventud (Ewen, 1983: 143-151). La apelación a la juventud se revelaba, en efecto, como un hecho clave para aquellos empresarios y publicistas interesados en la creación de nuevos consumidores (Lash, 1984: 43-44). Y para ello era también clave, tal como pensaba 
un publicista norteamericano a finales de los años 20 del siglo pasado, dirigirse a sus padres. "Si los niños- decía- eran criados al modo "liberal" que caracteriza al mundo moderno e industrial, entonces las grandes empresas estarían en disposición de intervenir en la definición y en los valores de la cultura familiar" (Ewen, 1983: 145).

Gradualmente- a lo largo de la década de los años 20 en Norteamérica- la publicidad se irá así orientando cada vez más hacia la juventud, mostrando esta categoría de edad como un modelo de actitud hacia el consumo (Ewen, 1983: 148). Más tarde, a mediados de la década de los 40 , emergerá el concepto de adolescente, utilizado por los empresarios y por los publicistas norteamericanos como el icono de una clase especial de consumidores (Savage, 2007).

A partir de este momento, y especialmente después de la Segunda Guerra Mundial, comenzará a crecer la distancia entre jóvenes y adultos, a medida que los primeros se afirmen cada vez más con respecto a los segundos, en virtud de sus particulares modos de vida, cada vez más relacionados con el mundo del consumo (Coleman, 1961). Gradualmente, esta distancia se resolverá en imitación, cuando la juventud se erija en el modelo generacional por excelencia de la cultura occidental. Todo este proceso tuvo uno de sus hitos fundamentales en el fenómeno de la contracultura, que se manifestará primeramente en los años 50 en Norteamérica, y posteriormente, en los 60, en Europa. La contracultura supuso, en efecto, un canto a la libertad y a la autorrealización personal, y un grito enérgico contra toda forma de jerarquía y de autoridad y, por tanto también, contra toda imposición institucional. Significó, por ello, un contundente rechazo a cualquier forma de tradición, y una reivindicación de las nuevas experiencias vinculadas a los estilos de vida de esta nueva generación contracultural. El impulso de este movimiento fue incorporado provechosamente por el mundo del consumo y la publicidad (Frank, 2011: 63; Heath y Potter, 2005).

En este contexto, como antes se ha dicho, los mundos de vida de jóvenes y adultos se separaron cada vez más, a medida que los segundos tenían menos experiencias que comunicar a los primeros para que éstos se integrasen en un mundo que ya no era el suyo.

Hasta hace muy poco tiempo- escribió Margaret Mead-, los mayores podían decir: "¿sabes una cosa?, yo he sido joven y tú nunca has sido viejo”. Pero los jóvenes de hoy pueden responder: "tú nunca has sido joven en el mundo en el que yo lo soy, y jamás podrás serlo" (Mead, 1971: 92).

La antropóloga norteamericana sintetizó así la idea de una ruptura generacional, a la que conceptualizó con el término prefiguración (1971: 91). En las culturas 
prefigurativas- dijo- "hemos de reconocer que no tenemos descendientes, del mismo modo que nuestros hijos no tienen antepasados" (Mead, 1971: 109).

Una de las manifestaciones más claras de dicha ruptura generacional, en un contexto de prolongación de la edad escolar y de incremento del desempleo juvenil, fue la erosión de la ética del trabajo y de la cultura escolar bajo el imperativo de los valores del consumo (Moya, 1984: 339-40).

Hasta ese momento ambas culturas, la del trabajo y la escolar, habían coexistido, bien alimentándose, o incluso oponiéndose. En este último caso, los ritos de liberación de la cultura escolar conllevaban la adhesión a los valores del trabajo identificados con el mundo adulto (Willis 1988). Dicho de otro modo, la oposición y la exaltación de la subjetividad juvenil que tenía lugar en la esfera educativa, resultaba compensada en cierta medida por la asunción del deber productivista vinculado a la edad adulta.

La cultura del consumo actúa, sin embargo, en otra dirección. Participa ante todo de ritos de liberación con débil incorporación (Bell, 1977: 164). En otras palabras, las metas que persiguen los consumidores se vinculan más con la independencia, la autonomía y la expresión de la propia identidad, que con la pertenencia cultural o institucional. Se expresan más en el lenguaje del deseo que en el de la renuncia y el sacrificio; se conciben más, en fin, como derechos del individuo que como deberes colectivos. Esta nueva moral, vinculada al ideario juvenil, ha conquistado los más diversos ámbitos de la vida individual y colectiva (Lipovestky, 2003: 39-40; 1994: 164 y ss). De una cultura del rechazo, más propia de los años 60 y 70, se transitó así a otra de secesión (Gauchet, 2002: 138-39), en la que los deberes asociados al mundo educativo y laboral resultarían cada vez menos comprensibles para una juventud cuyas biografías se asociaban crecientemente a los valores del consumo.

\subsection{JUVENTUD Y CULTURA DEL CONSUMO}

El consumo se ha asociado con la juventud desde los inicios de las modernas sociedades de consumo de masas. Los jóvenes de esta generación fueron los primeros que anticiparon su entrada en el mundo del consumo a la del mercado de trabajo, proyectando sus experiencias de autonomía y de libertad personal sobre el amplio abanico de bienes que les ofrecía el mercado. La incorporación a la edad adulta, hasta ese momento presidida por los ritos de paso asociados a la transición al trabajo o a la formación de una familia, se retrasó y se reemplazó por otro tipo de experiencias vinculadas a los estilos de vida y a los valores del consumo (González-Anleo, 2014: 96; Feixa, 2014: 146 y ss; Duque, 2007: 71; Moya, 1984: 340; Pais, 2009: 372; 2005; 2003a). 
Todas estas experiencias se vieron favorecidas, además, por la prolongación de la escolarización, y por las dificultades de integración en el mercado de trabajo (Artiaga et al 2014a; Silva e Pereira, 2012). Todo lo cual ha hecho que el trabajo sea percibido cada vez más como un valor instrumental; como un medio para poder participar en la sociedad de consumo (Andrade et al, 2012; Conde, 1999: 31-36).

De este modo, mientras que para la generación del baby-boom, ya socializada en la cultura del consumo, la educación y el trabajo todavía se entendían como transiciones biográficas necesarias para ingresar en el mundo adulto, para las generaciones posteriores estas transiciones se han dilatado tanto que el peso de la identidad recae cada vez más sobre el mundo del consumo, con todas sus proclamas de individualidad, libertad y autorrealización personal (Lipovetsky, 2007: 197 y ss; Featherstone, 2000: 142). Así, si para los jóvenes nacidos en los años 50 y 60 las transiciones a través de las distintas instituciones socializadoras- familia, educación, trabajo- se interpretaban todavía como parte de un proceso de construcción biográfica proyectado hacia el futuro, para la juventud posterior esta secuencia se resuelve cada vez más en el ciclo amplio de la cultura del consumo, que difumina aquellas transiciones en un solo presente, el del consumo (Bauman, 2007a; Conde, 1999: 55 y ss; Lipovetsky, 1987: 50 y ss).

Este proceso ha tenido importantes consecuencias en las formas de socialización y de construcción de la identidad juvenil. En efecto, éstas se han hecho más individualistas, libres, cambiantes y flexibles en relación con los distintos estilos de vida que la sociedad de consumo parece hacer realizables a través de su amplia oferta de bienes (González-Anleo, 2014: 105-106). Dentro de este vasto abanico de estilos de vida caben incluso las actitudes más contraculturales y rebeldes, manifestadas, eso sí, con los símbolos y el lenguaje de la cultura del consumo (Frank, 2011; Heath y Potter, 2005).

Los rituales juveniles delatan la dirección y el significado de este cambio. Si para las generaciones más socializadas en el mundo escolar y productivo marcaban los distintos momentos de una trayectoria a través de los diferentes universos institucionales, celebrando la liberación de un orden para la integración en el otro. Para los jóvenes más socializados en la cultura del consumo señalan ante todo la liberación más que la incorporación (Bell, 1977: 164), sin otras proyecciones que las del presente. Esta cultura se ha convertido en una de las principales señas de identidad para toda una generación de jóvenes, especialmente para los nacidos en la etapa del capitalismo de consumo.

El consumo se ha convertido así en un potente medio de inculturación para la juventud, compitiendo eficazmente con otras instancias socializadoras como la familia, la escuela o el mundo del trabajo, que ya no tienen el peso institucional y cultural de otras épocas. De este modo, el consumo ha contribuido a modificar 
las experiencias biográficas de los jóvenes, particularmente las de los nacidos a partir de la segunda mitad de los años 80 del pasado siglo. En efecto, cuanto más se vinculan dichas experiencias al mundo del consumo, más intervienen en la esfera educativa y en la del trabajo, modificando la orientación de los jóvenes hacia ellas.

Esta realidad será ejemplificada a través del análisis de la juventud española y portuguesa. En ambos países los jóvenes habrían experimentado un proceso de cambio similar al ocurrido en el mundo occidental, si bien con más retraso. Así, en un primer momento, durante la etapa del capitalismo de producción, la ética del trabajo y la cultura escolar serían las dominantes, imponiendo sus propios valores y su particular temporalidad a la juventud de la época. Pero más tarde, a medida que se transita del capitalismo de producción al de consumo, la cultura del consumo iría cobrando una mayor fuerza con relación a las otras dos culturas. En este contexto, la educación y el trabajo adquirirían un carácter más instrumental para la mayoría de los jóvenes, en función de la lógica dominante en el mundo del consumo. Produciéndose, además, una progresiva separación entre los espacios y los tiempos dominantes en cada una de estas esferas.

Este sería el proceso seguido por las 3 generaciones de jóvenes españoles y portugueses que se analizarán a continuación.

\subsection{Trayectorias generacionales. ACtitudes, valores y TEMPORALIDADES DE 3 GENERACIONES DE JÓVENES ESPAÑOLES Y PORTUGUESES EN RELACIÓN CON EL MUNDO DE LA EDUCACIÓN, EL TRABAJO Y EL CONSUMO}

\subsubsection{Introducción: planteamiento y conceptos}

Antes de adentrarnos en lo que será el objetivo principal de este epígrafe, será preciso aclarar, aunque sólo sea brevemente, tres de los conceptos centrales que lo articulan; a saber, juventud, generación y cultura.

Desde una perspectiva más elemental pueden considerarse jóvenes a todas aquellas personas que han abandonado la infancia sin haber alcanzado todavía plenamente la edad adulta. No obstante, esta transición depende del significado que cada sociedad atribuya a cada una de estas etapas de la vida (Lévi y Schmitt, 1996).

Desde este punto de vista, en las 3 generaciones que se analizarán a continuación la duración de la juventud estará determinada por la más temprana o tardía incorporación a los ámbitos institucionales característicos del mundo adulto ${ }^{64}$. Y la

${ }^{64}$ Así, por ejemplo, la encuesta de Juventud de 1960 estableció como periodo juvenil el comprendido entre los 16 y los 20 años, considerando que a los 21 años se incorporaban los varones 
identidad juvenil vendrá conformada a partir de las experiencias sociales y culturales que constituyen el marco de la historia compartida por los miembros de cada generación (Margulis y Urresti, 1996: 26). Estas experiencias se construirán, en el caso de las tres generaciones que hemos diferenciado, a partir de la participación de los sujetos en las tres culturas objeto de nuestro análisis- la educativa, la laboral y la del consumo- configurando una determinada memoria, y también una serie de valores y de expectativas.

En este contexto cobra precisamente sentido el concepto de generación (Manheim, 1990; Ortega y Gasset, 1961). La generación es más que una coincidencia cronológica, puesto que conlleva una serie de experiencias, actitudes y valores comunes en relación con diferentes ámbitos sociales y culturales (Caballero y Baigorri, 2018; Benedicto, 2016: 20; Leccardi y Feixa, 2011: 17 y ss; Martín Serrano, 1994: 18). Estas experiencias, que crean determinadas condiciones y oportunidades (Wyn y Woodman, 2015: 55), serán más o menos fuertes en virtud de su capacidad para articular la vida social e individual de los miembros de cada generación.

El trabajo, la educación y el consumo han funcionado precisamente a lo largo de las distintas etapas de la modernidad como universos culturales que han condicionado las experiencias, los valores y las aspiraciones de los individuos. El trabajo y la educación, al ser los instrumentos principales del progreso individual y colectivo; los medios más legítimos para posicionar a los individuos en la sociedad, y también los escenarios por antonomasia de la integración social y del cumplimiento de un deber moral. El consumo, al haber impulsado, en una segunda fase de la modernidad, una cultura más individualista, centrada en la autonomía y en la expresión de la personalidad; más favorable a la liberación que a la integración, más hedonista que sacrificial, y más focalizada también en el presente.

En la medida en que estos tres ámbitos han sido reconocidos por la juventud de cada generación como una parte importante de sus procesos de socialización, otorgando un determinado sentido a sus respectivas biografías, más han entrado a formar parte de sus particulares mundos de vida. Por el contrario, cuanto menos capacidad han tenido para producir y reproducir la identidad juvenil, para articularla y otorgarle un determinado significado, más ajenos han estado a sus experiencias, valores y expectativas. Con este criterio se analizará la fuerza de cada una de estos ámbitos en las tres generaciones objeto de este estudio.

Precisemos una importante cuestión más, no por ello menos importante. La juventud no puede ser percibida únicamente como una categoría de edad, en ella influyen otras variables que también intervienen en su configuración, como por

al servicio militar, abandonando así la juventud para integrarse en los escenarios del mundo adulto (De Miguel, 2000: 22). 
ejemplo la clase social (Martín Criado, 1998: 67 y ss). La cuestión, que en este caso se plantea, es si estas variables ejercen tanta influencia que no tendría sentido referirse a la juventud como una experiencia socio-cultural común.

Sin negar la diversidad de circunstancias que intervienen en la configuración de ser joven, muchas de ellas relacionadas con la clase social, tal como pondremos de manifiesto en este análisis, creemos que es posible observar ciertas actitudes y experiencias comunes relativas a la juventud de cada periodo que se pueden analizar, explicar y comprender en términos generacionales ${ }^{65}$ (Elzo, 1999: 404-405). Estos elementos comunes se vinculan, en el caso particular aquí observado, con la relación mantenida por los miembros de cada generación con las esferas de la educación, el trabajo y el consumo, en el contexto del proceso que va del capitalismo de producción al de consumo.

Con este criterio se han diferenciado 3 generaciones. La primera, se correspondería con los nacidos en el periodo 1935/1945, socializados fundamentalmente en la ética del trabajo, y con una mayor tendencia a la reproducción que a la aspiración.

La segunda generación -la del periodo 1955/1965- pertenece a un momento de transición, en el que la cultura del consumo va cobrando un mayor protagonismo con respecto a la del trabajo y a la educativa, pero sin erosionarlas sustancialmente. Los miembros de esta generación- especialmente los que están en la segunda etapa de su juventud- mantendrán todavía, por tanto, una orientación hacia el logro educativo y el laboral, aunque dicha orientación será bastante más débil para los nacidos al final de este periodo, anunciando los valores dominantes en la siguiente generación.

Se trata de una juventud que pretende liberarse de los esfuerzos y de los sacrificios de sus padres, pero aceptando todavía, en cierta medida, la sumisión a las estructuras institucionales del mundo educativo y productivo; aunque esta aceptación va perdiendo fuerza, sobre todo para los jóvenes nacidos en la década de los años 60. Para estos jóvenes va cobrando una mayor importancia la esfera del consumo, a medida que interviene cada vez más en la conformación de sus biogra-

65 Cualquier concepto sociológico que se utilice para explicar una serie de fenómenos de la realidad social, es susceptible de ser analizado a su vez sociológicamente a partir de la problematización de las dimensiones que lo integran; dimensiones que tienen que ser de algún modo oscurecidas con el fin de potenciar la capacidad explicativa y comprensiva de dicho concepto. En este sentido, todos los conceptos, como ya señalara Max Weber, son típico-ideales. Y lo son porque, como él sostuvo, resaltan unidimensionalmente ciertos aspectos de la realidad, con el fin de comparar el concepto así construido con esa misma realidad que se pretende explicar y comprender (Weber, 1993: 16 y ss). De lo contrario, los fenómenos sociales sólo podrían ser contemplados a partir de la multiplicidad de fragmentos que los constituyen, ganando en minuciosidad lo que se perdería en capacidad analítica. 
fías. Su perspectiva temporal ya no se inclina, por tanto, a superar el pasado, sino a programar el futuro desde la situación presente.

Por último, la tercera generación- la de los nacidos en la etapa 1975/1985es la integrada por una juventud que se define ante todo como consumidora, tal como lo atestiguan las diferentes encuestas desde 1994 (González Blasco, 1999: 252). Se trata, por tanto, de la generación más plenamente socializada en los valores del consumo, que van a ejercer una mayor influencia en el ámbito educativo y el laboral, contribuyendo a transformar las expectativas de la juventud hacia estos dos ámbitos, que finalmente resultarán atravesados por la cultura del consumo. La meta de estos jóvenes es la autonomía y la liberación, más que la incorporación. Se trata, por ello, de la generación más rupturista, con una orientación temporal presentista, sin demasiados vínculos ni proyecciones hacia el futuro.

Para realizar este análisis se han empleado diferentes informes y encuestas de juventud pertenecientes al periodo cronológico de las tres generaciones antes descritas. En el caso de España, se han utilizado fundamentalmente los publicados periódicamente desde 1960 bajo el patrocinio de distintas instituciones, y que proporcionan un completo cuadro temporal de la evolución de los valores y de las actitudes de las distintas generaciones de jóvenes (De Miguel, 2000: 15). Para Portugal, se ha recurrido a diversos estudios realizados en el ámbito del Observatório Permanente da Juventude, creado por la Secretaria de Estado da Juventude, que hasta la fecha ha producido diversos trabajos sobre la realidad de la juventud portuguesa. Para este país se han utilizado, asimismo, los datos oficiales del Instituto Nacional de Estatística, del Ministério da Educação, del Instituto do Emprego e Formação Profissional, y del Ministério do Trabalho e da Solidariedade. En este país no existe sin embargo una continuidad cronológica en los estudios de Juventud, como la que sí hay en España. Si bien se cuenta con un pionero y muy completo estudio sobre la juventud universitaria portuguesa (Nunes, 1968), dicho estudio no tuvo la regularidad deseable en el tiempo, de modo que hasta los años 80 no comienzan a proliferar los análisis sociológicos sobre la juventud portuguesa ${ }^{66}$ (Guerreiro y Abrantes, 2003: 241; Pais, 1996). Además, muchos de estos trabajos, sobre todo los producidos hasta los años 90, se basan más en fuentes estadísticas que en encuestas de opinión. Por todas estas razones, las comparaciones entre España y Portugal resultan en ocasiones difíciles y complejas, por lo que, en el caso de las dos primeras generaciones, no se han podido llevar al ámbito de las vivencias y de las representaciones del tiempo. De todos modos, aun con todas estas limitaciones, se ha intentado, y esperamos haberlo logrado en alguna medida, hacer una primera

${ }_{66}$ Tal como se puede comprobar en la muy completa recopilación bibliográfica sobre la juventud portuguesa realizada por Pais (1996). 
aproximación compartativa a las juventudes de ambos países. El resultado es el que se mostrará seguidamente.

\subsubsection{Modos de percibir y de orientar la juventud. Actitudes y valores ante el trabajo, la educación y el consumo de 3 generaciones de jóvenes españoles y portugueses}

\section{a. Generación 1935-1945}

Es la generación menos identificada con una hipotética cultura juvenil o adolescente, ya que en su periodo de juventud el modelo social a imitar era todavía el de los adultos, representados sobre todo por la figura del padre. En este rol paterno se reconocían todavía muchos de ellos, y por tanto también en las estructuras de una familia jerárquica con fuertes divisiones de género, tal como reflejaba la encuesta de Juventud de $1960^{67}$ (De Lora, 1965: 63 y ss; 119 y ss). Se trata también de la generación que más tempranamente abandonará la juventud, debido a su pronta incorporación a los escenarios del mundo adulto, tales como el trabajo y la formación de una familia. De hecho, la mayoría de estos jóvenes aspiraban como ideal de vida a conseguir un trabajo y a casarse (De Miguel, 2000: 22; De Lora, 1965: 169). $\mathrm{Y}$ eran, asimismo, mayoría los que habían sido educados en su infancia en la cultura del ahorro vinculada al capitalismo de producción; cultura con la que romperán más tarde, ya en edad adulta, coincidiendo con la etapa del desarrollismo de los años 60.

Es también la generación más socializada en la ética del trabajo, en virtud de su corta trayectoria académica, su temprana incorporación al mundo laboral y de su reducida capacidad de consumo.

La mayoría de estos jóvenes pretendían, o bien "situarse", en el caso de los más privilegiados, continuando así las trayectorias de sus padres, o tener un trabajo, en el caso de los jóvenes de las clases más populares; siendo muchos menos los que aspiraban a ascender de posición social o a cambiar de lugar de residencia (De Lora, 1965: 167 y ss).

Desde el punto de vista temporal, es una generación para la que el pasado todavía cuenta, en relación con actitudes que todavía eran en su mayoría reproductivas, aunque comienza a advertirse, hacia finales de la década de los 60 , un mayor

7 La encuesta de Juventud de 1960 se realizó a una muestra de jóvenes comprendidos entre los 16 y los 20 años de edad; concretamente a 1318 varones y a 421 mujeres. La edad límite de 20 años se estableció atendiendo al hecho de que a los 21 años se entraba en el servicio militar, verdadero rito de paso a la edad adulta (De Miguel, 2000: 22). 
optimismo con respecto al futuro, en relación con los efectos del desarrollismo y la modernización.

En lo que sigue, trazaremos más pormenorizadamente las características de la juventud de esta generación en relación con sus actitudes y valores con respecto a los tres ámbitos objeto de este estudio, el educativo, el laboral y el del consumo, y también con relación a sus vivencias y representaciones del tiempo.

\section{Educación: el camino para la reproducción social}

Desde el punto de vista educativo es la generación con más baja participación académica, tanto en estudios secundarios como universitarios. En el año 1960 únicamente estudiaban el 25\% de los jóvenes comprendidos entre 15 y 20 años, con un importante componente de clase (García Ferrando, 1984a: 24). Así, según los datos de la encuesta de juventud de 1960, 8 de cada 10 estudiantes procedían de padres de clase media u acomodada, mientras que sólo 1 de cada 10 tenía padres obreros (De Lora, 1965: 57-58). Todavía en 1970 solamente el 8\% de los estudiantes universitarios eran hijos de obreros (De Miguel, 2000: 44 y ss). La educación actuaba así como un potente mecanismo de reproducción social, pues no sólo eran mayoría los estudiantes de niveles medios y superiores que procedían de familias con cualificaciones académicas, sino también los que elegían estudios del agrado de sus padres (De Lora, 1965: 69). Padres con los que los estudiantes se sentían tan identificados que los consideraban modelos a imitar, incluso por encima de personajes históricos o públicos (De Lora, 1965: 119).

No obstante, y a pesar de su escasa participación educativa, la educación era percibida por los hijos de los obreros como un mecanismo de movilidad social, en relación con las posibilidades que parecía ofrecer el medio industrial, pero también por el prestigio que se atribuía a la posesión de un determinado nivel cultural. Así, en la encuesta de juventud de 1960, la mayoría de los jóvenes con trabajos no agrarios, al ser preguntados por los estudios que desearían realizar, la mayoría de ellos optaba preferentemente por los de carácter técnico de nivel medio (De Miguel, 2000: 64); considerando, asimismo, que la cultura era "lo más importante para situarle a uno en la sociedad”, aunque eso sí, por detrás del dinero (De Lora, 1965: 174).

En Portugal, la participación académica de la juventud de esta generación era todavía más baja que la de España, pues en 1960 la tasa de escolarización de los jóvenes comprendidos entre 15 y 29 años era del 6,6\% (INE, 1960). Se trata de un momento- el correspondiente a los años 60- en el que este país todavía no había abordado las grandes reformas de la enseñanza, emprendidas más tarde por Veiga Simão, y consolidadas después del 25 de abril. La enseñanza tenía por tanto en 
Portugal, lo mismo que en España, un fuerte componente de clase, especialmente en el caso de la universidad, en la que la "gran masa de los estudiantes- entre el 76\% y el $90 \%$ - procedía de los dos grupos que detentaban las posiciones socioeconómicas más favorecidas" (Nunes, 1968: 327).

\section{Actitudes y valores laborales: formas de ser y de aspirar a ser}

La cultura del trabajo era relativamente fuerte en los jóvenes de esta generación. En realidad, para muchos de ellos no existían otras culturas que compitiesen eficazmente con la laboral, ocupación principal de la mayoría ${ }^{68}$. Esta presencia temprana del trabajo reforzaba, pues, sus vínculos con esta esfera. Así aparecía reflejado en su sistema de valores. En efecto, entre las cualidades que más decían admirar de sus padres los jóvenes de $1960^{69}$, con independencia de su clase social, estaban el "ser trabajador" y el tener "sentido del negocio" (De Lora, 1965: 59-60). El trabajo como ideal de vida conformaba, pues, la mentalidad de la mayoría de estos jóvenes, no sólo por razones de orden material- las del salario- sino también por lo que significaba en términos de cumplimiento del deber personal, social y moral (Muñoz Carrión, 1994: 216). El mundo laboral y el familiar constituían así el fundamento de las aspiraciones de los miembros de esta generación (De Lora, 1965: 168-169). Pero estas aspiraciones estaban muy poco vinculadas a la idea de ascenso social, sobre todo entre los campesinos y los estudiantes, pues estos últimos lo que querían mayoritariamente era "situarse", siguiendo las trayectorias privilegiadas de sus padres, mientras que los campesinos y los trabajadores lo que pretendían ante todo era tener un trabajo, representado todavía por la idea presindustrial del oficio. Aun así, comenzaba a percibirse una cierta inquietud por ascender socialmente entre los jóvenes trabajadores, aunque a tenor de la encuesta de 1960 todavía era minoritaria (12\%). En efecto, ninguno de estos grupos de jóvenes aspiraba mayoritariamente a "ascender" o a "cambiar" de lugar de residencia, sino a reproducir trayectorias biográficas y modelos de vida (De Lora, 1965: 167 y ss).

Esta valoración del trabajo seguiría estando presente muchos años después en los que habían sido jóvenes en la primera mitad de los años 60, y que se encontraban en la mediana edad en 1994. En efecto, tal como ponía de manifiesto la encuesta del CIS de ese año, en la que se preguntaba sobre "si la autorrealización personal se conseguía en el trabajo o fuera de él", entre el 42 y el $44 \%$ de los adultos de mediana edad encuestados respondieron que era allí, en el trabajo, donde

68 Según la encuesta de juventud de 1960, el 66\% de los jóvenes encuestados entre 16 y 20 años se encontraba precisamente en dicha situación (De Miguel, 2000: 141).

69 En la encuesta de 1960 se dividió a los jóvenes en 3 grupos: estudiantes, campesinos y trabajadores (De Lora, 1965). 
la lograban, frente al 28-24\% que situaba esta realización fuera del trabajo. Por el contrario, en los jóvenes de 15 a 25 años esta relación prácticamente se invertía (Andrés Orizo, 2001: 236-344).

En Portugal, esta etapa generacional coincide, al igual que en España, con un periodo de importante desarrollo económico, que no alcanzó sin embargo la dimensión que tuvo en el vecino país ibérico. Así, de una tasa de crecimiento que rondaba el 3,5\% entre 1956-1958, se pasó a otra del 5,3\% en 1959, y de esta al 8,8\% en 1960 (OCDE). Es el momento en el que Portugal comienza a industrializarse al compás de este impulso económico (Rocha: 1977: 595).

\section{Ocio y consumo: recreo y descanso para una vida de trabajo}

Mientras que la cultura del trabajo era sólida para la juventud de esta generación, la del consumo apenas estaba presente. La moda, que será una de las principales manifestaciones de dicha cultura para la juventud de las generaciones posteriores, apenas era valorada por la mayoría de los miembros de esta generación, al menos a tenor del escaso repertorio de su vestuario (De Miguel, 2000: 36). En cuanto al ocio, otro de los aspectos que posteriormente más se vinculará con el estilo de vida juvenil, no aparece entre las dimensiones que los jóvenes de esta generación consideran que van a ser más importantes en sus experiencias futuras. Así, la encuesta de juventud de 1960, al preguntar a los estudiantes- que tradicionalmente son los que más tiempo y más libertad tienen para disfrutar de la vida- sobre las "actividades que en el futuro esperaban que les fueran a dar mayor satisfacción", únicamente el 8\% destacaba el ocio entre ellas, frente al 47\% que valoraba la profesión (De Miguel, 2000: 63-64). Aun así, en contraste con sus padres, comenzaban a apreciar el entretenimiento y la diversión como ámbitos a tener en cuenta también en la vida (De Lora, 1965: 65). El sacrificio y el trabajo duro, como principales ejes de la existencia, empezaban a compaginarse, en una generación que ya no había conocido la guerra, con otras actitudes más proclives a disfrutar algo de la vida. Pero este disfrute se concebía más como el necesario descanso reparador que compensaba los sacrificios y los esfuerzos laborales, que como un tiempo cargado con su propio significado (Comas, 2000: 15).

En Portugal, aunque no se dispone para este periodo de encuestas de juventud que interroguen a los jóvenes específicamente sobre su consumo, se puede decir que la juventud iba alimentando los sueños de abandonar la vida dura del mundo agrario tradicional, cuyo espejo eran sus progenitores. A semejanza de lo que ocurría en España, sus preocupaciones giraban más alrededor de la familia y del trabajo que del tiempo de ocio y de consumo (Pais, 1996: 199). 


\section{Tiempo: sin perder de vista el pasado, pero abriéndose al futuro}

La concepción del tiempo de los jóvenes de esta generación se vinculaba, en su mayoría, con la idea de la gratificación postergada. Idea que quizás se ponía de manifiesto en el desacuerdo que mostraban la mayoría de ellos- el 63\%, concretamente-, con la pregunta que se les planteaba en la encuesta del CIS de 1967, a saber, "el futuro es tan inseguro para los jóvenes que mejor es vivir al día" (De Miguel, 2000: 258; Muñoz Carrión, 1994: 213-214). El futuro representaba para la mayoría de ellos, por el contrario, la posibilidad de superar las limitaciones del presente o, cuando menos, en el caso de los hijos de las clases más privilegiadas, de reproducir sus condiciones sociales. En la encuesta de 1968, cuando los efectos del desarrollismo comenzaban ya a advertirse, más de la mitad de los jóvenes (el 52\%) creían que les aguardaba un futuro prometedor, siendo muy pocos (16\%) los que lo enfrentaban con una actitud pesimista (Muñoz Carrión, 1994: 207-208).

En resumen, se trata de una generación situada a medio camino entre el mundo tradicional y el moderno, que continuaba valorando las estructuras de una familia jerárquica basada en las divisiones de género, y que no tenía abiertas discrepancias con sus padres, a los que aún ven como modelos (De Lora, 1965: 119 y ss). La juventud de esta generación valora sobre todo el mundo del trabajo y de la educación como parte del cumplimiento de un deber moral y social. Una valoración que se vincula más con la reproducción social que con el cambio y la movilidad social. Esta escasa valoración del ascenso social se manifestaba también en las cualidades que se juzgaban más apropiadas para triunfar. Entre estas cualidades se situaba en segundo lugar la "buena suerte" y a continuación el "conocer gente influyente", aspectos valorados especialmente por campesinos y trabajadores, aferrados todavía a un mundo preindustrial en el que los valores meritocráticos del mérito y la capacidad no estaban aún muy presentes (De Lora, 1965: 172-173).

No obstante, estos jóvenes comenzaban a reclamar más libertad, aunque se tratase más de una libertad de hacer que de pensar (Velarde, 1994: 107). Si bien el ocio no estaba en el centro de sus preocupaciones presentes ni futuras, aspiraban ya a una vida más desahogada en la que hubiese también momentos para el entretenimiento (De Lora, 1965: 62 y ss), aunque al margen de lo que pudiera llamarse una cultura del ocio (Comas, 2000: 13-14).

La juventud de esta generación aspiraba más a la integración que a la liberación, como lo ponía de manifiesto su aceptación de los valores jerárquicos e institucionales, pues la mayoría de ellos mostraban una actitud positiva hacia las instituciones más vinculadas a la autoridad y el orden (De Miguel, 2000: 67 y ss). 
Muchos de las actitudes y de los valores de los miembros de esta generación iban a experimentar importantes cambios en la juventud de la generación posterior, como se verá seguidamente.

Cuadro 4. Generación 1935-1945

\begin{tabular}{|c|c|c|}
\hline & Valores & Actitudes \\
\hline Educación & $\begin{array}{l}\text { Fuertes: mayoritariamente reproducti- } \\
\text { vos, minoritariamente orientados a la } \\
\text { promoción social. }\end{array}$ & $\begin{array}{l}\text { Reproducción social. } \\
\text { Orientadas claramente a la } \\
\text { integración. }\end{array}$ \\
\hline Trabajo & $\begin{array}{l}\text { Fuertes, asociados a un deber material, } \\
\text { social y moral. }\end{array}$ & $\begin{array}{l}\text { Reproducción social. } \\
\text { Favorables a la integración. }\end{array}$ \\
\hline Consumo & Débiles, supeditados al trabajo. & $\begin{array}{l}\text { Divertirse, para recuperarse del } \\
\text { cansancio y de la rutina laboral. } \\
\text { Liberarse un poco del tiempo } \\
\text { productivo. }\end{array}$ \\
\hline Tiempo & $\begin{array}{l}\text { Pasado (reproductivos), presentes (si- } \\
\text { tuacionistas), futuro (superación). }\end{array}$ & Reproductivas y sacrificiales. \\
\hline
\end{tabular}

\section{b. Generación 1955-1965}

Esta generación de jóvenes será la primera en integrarse en la cultura del consumo, si bien sus padres lo habían hecho ya con anterioridad, aunque en su etapa adulta. Se trata, pues, de la primera juventud que participa de las 3 culturas -la educativa, la laboral y la del consumo- coincidiendo con la fase de transición entre el capitalismo de producción y el de consumo.

Su experiencia en el mundo del consumo será por ello cada vez más fuerte, mientras que su actitud con respecto a las otras dos culturas, la laboral y la educativa, será más cambiante, pasando de un momento- aproximadamente hasta comienzos de los años 80 - de una orientación educativa y laboral más sólida, a otro, con posterioridad a esta fecha, en el que se debilitarán ambas culturas. Todo lo cual incidirá también en sus actitudes temporales, que van adquiriendo un carácter cada vez más presentista.

A diferencia de la generación anterior, los juventud de esta generación muestra una actitud más rupturista con sus padres, a medida que se identifica cada vez más con el grupo de iguales, tal como era posible observar a partir de la encuesta de 1974. Contrariamente a los jóvenes que les precedieron, la mayoría de estos 
jóvenes manifiestan un abierto desacuerdo con las estructuras familiares patriarcales, siendo partidarios de una familia más igualitaria y participativa (Velarde, 1994: 108 y ss).

\section{Educación: entre aspiraciones y desencantos}

Esta generación de jóvenes- especialmente los nacidos en la década de los 60es la que protagonizará la expansión educativa en sus distintos niveles ${ }^{70}$. No obstante, al coincidir dicha expansión con una etapa de crisis económica, se observa también un progresivo descenso de las expectativas con respecto a los estudios (en 1975 el 21\% tenía confianza en que los estudios le sirviesen para tener éxito en la vida; sin embargo en 1982 esta cifra había descendido al 10\%). Este descenso de las expectativas escolares se reflejaba también en el porcentaje de jóvenes que entre 1977 y 1982 optaban por continuar sus estudios o comenzar a trabajar. Los primeros eran más en 1977 (59\% frente a 36\%), invirtiéndose la situación en 1982 (38\% y $59 \%$ respectivamente); inversión que era todavía mucho más clara en las clases bajas y medias-bajas que en las medias y medias-altas, en las que un $41 \%$ de los jóvenes confiaban en que los estudios mejorarían su vida. A partir de mediados de los años 80 estas cifras se reequilibran, manteniéndose así hasta el final de la década (Martín Escudero, 1994: 130-131). Aun así, en general, seguían siendo mayoríamás de la mitad- los que albergaban la esperanza de que sus títulos les ayudasen a conseguir un trabajo satisfactorio, tal como se mostraba en las encuestas realizadas entre 1974 y 1984 (Martín Escudero, 1994: 146; García Ferrando, 1984b: 65 y ss).

Este panorama resulta más claro si se comparan las actitudes ante los estudios de los jóvenes de las distintas clases sociales, tal como hizo Alfonso Ortí en 1982 a partir de una serie de Grupos de discusión (Beltrán, 1984: 200-201). En dichos grupos, mientras que los miembros de las clases altas y medias-altas tenían una orientación positiva hacia los estudios como camino hacia el éxito profesional, las clases obreras urbanas aspiraban, por el contario, a incorporarse al trabajo para poder así integrarse en el mundo adulto. Por su parte, los hijos de las clases medias-bajas urbanas compartían ambas actitudes. En este contexto no existía, pues, una clara oposición entre la cultura laboral y la escolar. Para unos- los jóvenes de clase obrera urbana- la liberación de la cultura escolar suponía la adhesión al mundo del trabajo, con todas las obligaciones requeridas; para los otros- los jóvenes de clase alta y media/alta- la vinculación con la vida escolar se relacionaba con la perspectiva de un posterior logro profesional.

70 Mientras que en 1960 sólo el 25\% de los jóvenes menores de 21 años estaba estudiando, a mediados de los 80 esta cifra se había elevado al 60\%, y en el 91 era ya del 64\% (De Miguel, 1992: 593; Beltrán, 1984: 55). 
Esta situación iba cambiar gradualmente a partir de mediados de los años 80 , a medida que se reducían las expectativas sobre los estudios en relación con un mundo laboral cada vez más precario, hecho que, tal como se ha visto, comenzaba ya a apreciarse en la encuesta de 1982. Todo lo cual iba a incidir en la erosión de las dos culturas- la educativa y la laboral-, en función de las menores expectativas que generaban cada una de ellas. En efecto, la educación iba a convertirse en el medio para postergar la entrada en el mundo del trabajo, un mundo que cada vez ofrecía menos oportunidades ${ }^{71}$. Estas circunstancias contribuirán más tarde, sobre todo a partir de la década de los 90, a debilitar la ética del trabajo y la cultura escolar, al mismo tiempo que contribuirá a prolongar la exposición de los jóvenes a otras experiencias, como las del consumo.

En Portugal esta generación coincide también con una fuerte expansión educativa, la de los años 70. La educación será valorada principalmente por la mayoría los jóvenes de esta generación en relación con el mercado de trabajo. Así, según la encuesta de la FAOJ de 1982 (Fundo de Apoio aos Organismos Juvenis), el 70\% de los jóvenes consideraban que la escuela tenía como principal objetivo ayudar a conseguir una profesión. En esta misma línea se situaba la encuesta de la IED de 1983 (Ferreira, 1993). De todos modos, se apreciaban importantes diferencias de clase. Así, mientras que los jóvenes de familias de clase media y alta percibían la educación de acuerdo con estrategias de promoción o de reproducción social, los de los estratos sociales más desfavorecidos invocaban razones de orden económico para abandonar tempranamente la escuela (Schmidt, 1989).

De este modo, tanto en Portugal como en España, se observaban las mismas diferencias de clase en la juventud de esta generación. Los pertenecientes a las clases medias y superiores manifestaban una orientación hacia los estudios basada en la movilidad y la reproducción social, sin embargo, los de las clases más bajas se inclinaban por abandonar más tempranamente el sistema educativo, en busca de los recursos materiales que no les proporcionaba el medio escolar.

\section{Trabajo: de valor moral y social a actividad instrumental}

¿Qué ocurría con la cultura trabajo? Se advierte también una transición, sobre todo a partir de los años 80. En primer lugar, en lo que se refiere a la tasa de actividad de los jóvenes, que comienza a descender notablemente a partir de mediados de los años 70, acentuándose este descenso en los 80, hasta situarse en el 19\% en 1982 para la población comprendida entre 15 y 20 años. Proceso que corría paralelo, como cabría esperar, al incremento constante de la población escolar (García

\footnotetext{
se redujo entre 1981 y 1991 del 23\% al 12\% (De Miguel, 1992: 593).
}

De hecho, como consecuencia de la ampliación del número de estudiantes, el paro juvenil 
Ferrando, 1984a: 25 y ss). Esta mayor escolarización de la población juvenil, con su consiguiente alejamiento del mundo del trabajo, y su mayor proximidad a otros ámbitos de socialización, como los del consumo, influirá notablemente en sus actitudes y en sus valores con respecto al trabajo (González Blasco, 1994: 65-66).

En efecto, a partir fundamentalmente de mediados de los años 80 , es posible observar un cambio de orientación de los jóvenes con respecto al trabajo, en relación con una menor valoración de los aspectos morales y sociales de dicha actividad (Andrés Orizo, 1989: 196). Veamos más pormenorizadamente cómo se produjo este cambio. A comienzos de la década de los años 80 el trabajo todavía estaba asociado a la obligación moral y a la realización personal y social, aunque con importantes diferencias en función de las clases sociales. Al menos, esto era lo que se desprendía de la investigación cualitativa, ya citada, realizada por Alfonso Ortí en 1982 (citada en Beltrán, 1984: 200-201). Así, los jóvenes procedentes de familias urbanas obreras, consideraban que el trabajo era el medio principal para incorporarse al mundo adulto, con todas sus responsabilidades, tanto en términos de ayuda familiar como con respecto a uno mismo. La entrada en el mundo laboral se concebía, desde esta perspectiva, como parte de una relación intergeneracional que implicaba ciertas obligaciones de los hijos con respecto a los padres, con el objetivo de saldar una deuda familiar reconocida. Sin embargo, para los estudiantes de BUP y COU de clases medias-altas y altas, el valor positivo del trabajo se asociaba con el título académico, como principal camino para lograr el éxito profesional, configurando así un relato que era la expresión de los valores y de las expectativas de clase. Por su parte, los jóvenes pertenecientes a las clases medias-bajas urbanas, compartían las dos actitudes anteriormente descritas; aquella que percibía el trabajo como un modo de integración en el mundo adulto, y la que lo concebía como un medio de realización personal desde una perspectiva de clase (Beltrán, 1984: 200-201). No obstante, y a pesar de estas diferentes actitudes, todos los grupos de jóvenes atribuían al trabajo un carácter positivo como camino para lograr distintos objetivos en la vida (Beltrán, 1984: 200-201). Parecida opinión tenían la mayoría de los trabajadores jóvenes encuestados en 1974 y en 1984. Más de la mitad consideraba, según la encuesta del CIS de 1984, que ascender en su trabajo era más importante profesionalmente que por razones de salario (Martín Escudero, 1994: 146-160).

Como antes se ha comentado, estas actitudes hacia el trabajo van a experimentar una importante transformación a partir de comienzos de los años 80 (Andrés Orizo, 1995: 99). Una de las dimensiones de dicha transformación está representada por el declive de la centralidad del trabajo, tal como era posible observar comparando las encuestas de 1981 y de 1990. En ellas, se situaba a los entrevistados ante la tesitura de que en el futuro "fuera a disminuir la importancia del trabajo en nuestras vidas". Pues bien, en 1981 un 49\% contemplaba esa posibilidad 
como mala, frente al 38\% que la percibía como buena. 9 años más tarde- en 1990el 53\% consideraba que esa opción era buena frente al 35\% que entendía que era mala, siendo además la juventud la que más valoraba el trabajo en relación con el tiempo libre (De Miguel, 1992: 589-590). 4 años más tarde, en 1994, la tendencia continuaba siendo básicamente la misma, ya que un $53,9 \%$ de los jóvenes consideraban que su realización se producía fuera del trabajo (González Blasco, 1994: 41).

Esta pérdida de la relevancia del trabajo como conformador de la identidad juvenil, quizás se debiese a que ya no conservaba el ascendente social y moral que había tenido para los jóvenes de los años 60 (De Miguel, 1992: 589). En efecto, a partir de ahora esta actividad adquirirá un carácter cada vez más instrumental, vinculado con aspectos tales como los ingresos, la seguridad, la estabilidad y las relaciones sociales; al tiempo que irá perdiendo importancia desde la perspectiva de la utilidad social y del logro (Andrés Orizo, 1983: 264-65). Esta tendencia, que era ya perfectamente observable desde comienzos de los años 80 , se mantendrá a lo largo de toda esta década y la primera mitad de la siguiente. Así, en el periodo 1981-1994, entre las "cosas" que los jóvenes de 18 a 24 años consideraban "importantes en un trabajo", se encontraban a la cabeza los "buenos ingresos" (79\%, 1981; $70 \% 1994)$, que hubiese "agradables compañeros de trabajo" (69\% 1981; 61\% 1994) y "buena seguridad en el empleo" (64\% 1981; 58\% 1994). Por el contrario, resultaba mucho menos valorado que el trabajo fuese "útil para la sociedad" (46\% 1981; 36\% 1994), que existiesen "buenas oportunidades de ascenso" (42\% 1981; 32\% 1994), que en el trabajo se "pueda lograr algo" (43\% 1981; 32\%, 1994) o "que esté bien considerado" (39\%, 1981; 23\%, 1994) (Andrés Orizo, 2001: 232-233). Esta pérdida progresiva de la importancia del trabajo como fuente de identidad personal y de estatus social quedaba también constatada en la encuesta del CIS de 1989, en la que algo más de la mitad de los jóvenes encuestados de entre 15 y 29 años (el 53\% exactamente) declaraban preferir un buen sueldo antes que un trabajo con prestigio y peor pagado; asimismo, eran muchos más los que optarían, llegado el caso, por un trabajo decente y no muy absorbente, antes que por otro que les quitase más tiempo, aunque ganasen más y tuviesen mejores perspectivas de futuro (Martín Escudero, 1994: 162). Todas estas opiniones y actitudes eran la manifestación de la progresiva erosión de la cultura del trabajo entre los jóvenes (Andrés Orizo, 1989: 196), situación que iba en la dirección contraria a lo que estaba ocurriendo en el mundo del consumo.

Para la juventud portuguesa de esta generación el trabajo se percibía como una forma de realización personal y profesional, y no como una actividad instrumental. Únicamente el 6,2\% consideraba en 1987 que era importante tener un trabajo "para obtener el dinero que se precisa para satisfacer necesidades de consumo" (Ferreira, 1993). Eran muchos más- según la encuesta del ICS (Instituto de Ciências Sociais) de 1987- los que valoraban la realización profesional como 
el aspecto más importante de su vida futura (50\%), o como una dimensión muy importante de ella (82\%). Asimismo, según la misma encuesta, el 71,2\% de los jóvenes consideraban importante "tener un trabajo que les gustase realizar" (Ferreira, 1993). A tenor de estos datos, parece que la juventud portuguesa todavía no había desarrollado actitudes y valores instrumentales con respecto al trabajo, tal como comenzaba a ocurrir con la juventud española. Una instrumentalidad, que como luego se verá, estaba directamente relacionada con el ascenso de los valores del consumo.

\section{Consumo: de la gratificación postergada al hedonismo del presente}

Mientras que los valores y las actitudes asociados a la actividad laboral comenzaban a hacerse más instrumentales a partir de comienzos de los años 80 , los valores del consumo se consolidarán cada vez más a partir de esta fecha. Tal es así, que en el año 1981 los jóvenes comprendidos entre 18 y 20 años, y entre 21 y 24, eran los más disconformes con la pregunta que se les planteaba, a saber, "es agradable pensar en volver de nuevo al trabajo"; únicamente el 7\% de los pertenecientes al primer grupo de edad y el $17 \%$ del segundo se mostraban de acuerdo con dicha cuestión. El 63\% de los primeros y el 57\% de los segundos lamentaba, además, con pesar que se acabase el fin de semana (Andrés Orizo, 1983: 286).

Esta mayor inclinación de la juventud a apreciar y a disfrutar del tiempo libre, se relacionaba, naturalmente, con una mayor apetencia por el consumo y, en sentido contrario, por una desvalorización de la mentalidad del ahorro. Así, en 1982 menos de la mitad de los jóvenes comprendidos entre 18 y 24 años (el 46\%) estaba de acuerdo con la afirmación de que "sólo el disponer de algo ahorrado es lo que puede dar seguridad en esta vida", frente al $61 \%$ de las personas de otras edades. Asimismo, algo más de la mitad de estos jóvenes (el 55\%) respondieron afirmativamente a la pregunta: "cuando uno se lo pasa bien, no hay que pensar en el dinero que se gasta” (Andrés Orizo, 1985: 55).

Estos datos mostraban que se estaba produciendo un cambio de actitudes en una juventud que se orientaba cada vez más hacia los valores hedonistas y de autoexpresión personal, vinculados a un mayor deseo de vivir el presente, a costa de la renuncia a los valores de la gratificación postergada. Una renuncia que se antojaba ya innecesaria para conseguir lo que cada vez estaba más al alcance de la mano.

En Portugal, se empieza también a advertir una mayor identificación de la juventud con los bienes de consumo, aunque un poco más tarde que en España, aproximadamente en torno a finales de la década de los 80. Así se ponía de manifiesto en la encuesta del ICS de 1987 (ICS, 1987), en la que la mayoría de los jóvenes, con independencia de su clase social, manifestaba un parecido interés por 
los bienes vinculados a los audiovisuales y a las nuevas tecnologías, aunque, claro está, eran los miembros de las clases sociales más favorecidas los que más convertían sus sueños en realidad (Andrade, 1989). De todos modos, se estaba instalando gradualmente en la juventud portuguesa una mentalidad cada vez más favorable al gasto que al ahorro (Schmidt, 1990). Gasto para el que algunos contaban con los recursos familiares (el 52\% de los jóvenes entre 15 y 29 años se encontraba en esta situación de dependencia familiar en 1989), otros con los reducidos ingresos que aportaban trabajos precarios que había que complementar con ingresos familiares (jóvenes semiindependientes entre 15 y 29 años que representaban en 1989 el 21\% de la juventud), y el resto con sus propios ingresos, cuando disponían de trabajos que les permitían ser independientes (era el caso de los jóvenes de entre 25 y 29 años, que suponían el 26,8\% en 1989) (Pais, 1989).

Al mismo tiempo se producía una creciente valoración del tiempo de ocio entre amigos y pares (Ferreira, 1993; ICS, 1987), aspecto que ya comenzaba a ser apreciado a comienzos de la década de los 80 , tal como se mostraba en la encuesta FAOJ de 1982, en la que más de la mitad de los jóvenes valoraban la amistad como la dimensión que más contribuía a su bienestar (Ferreira, 1993).

Todas estas actitudes hacia el ocio y el consumo indicaban que probablemente se estuviese también instalando en la juventud portuguesa una nueva manera de vivir y de concebir el tiempo, aunque no se tengan datos específicos que corroboren es hecho. Datos, que como se verá en el siguiente epígrafe, si existen en España.

\section{Las representaciones del tiempo: el pasado ya no cuenta y el futuro no inquieta}

El cambio en la concepción del tiempo ya se advertía desde comienzos de los años 80. En efecto, hasta ese momento eran todavía mayoría los jóvenes que preferían pensar en el futuro antes que "vivir al día". Pero en el 81 ya eran más, por el contario, los que manifestaban una mayor vinculación con el presente, sin que esta orientación se viese modificada significativamente por otros factores como la clase social (Muñoz Carrión, 1994: 213-214). Concretamente, un 60\% de los jóvenes entrevistados, comprendidos entre los 18 y los 20 años, contestaron afirmativamente a la pregunta de que el "futuro es tan incierto, que lo mejor es vivir al día", porcentaje que se elevó unos años más tarde- en 1987- hasta el 70\% (De Miguel, 2000: 258; Andrés Orizo, 1995: 15 y 1985: 54).

Recapitulando lo dicho hasta aquí, podemos afirmar que la generación de los nacidos en el periodo 1955-1965 se correspondería con un momento de transición con respecto a las 3 culturas aquí analizadas, en el contexto del paso del capitalismo de producción al de consumo. En esta situación, la cultura educativa y la la- 
boral experimentan una mutación a partir de comienzos de los años 80 , a medida que se van erosionando los valores más vinculados al logro y al estatus social, que hasta ese momento habían gozado aún de un relativo predicamento, emergiendo en su lugar otros valores y otras actitudes más instrumentales. Al mismo tiempo, la cultura del consumo comienza a cobrar un mayor significado a partir también de los años 80, especialmente para los jóvenes que prolongan su escolarización, retrasando así su incorporación al mundo del empleo. Jóvenes que en su mayoría habían nacido ya en la década de los 60 . En este contexto emerge, a partir de los años 80 , una orientación temporal cada vez más vinculada al presente.

Todas esto cambios serán todavía más patentes en las décadas siguientes, tal como se mostrará al analizar la generación de los nacidos en el periodo 1975-1985.

Cuadro 5. Generación 1955-1965

\begin{tabular}{|c|c|c|}
\hline & Valores & Actitudes \\
\hline Educación & $\begin{array}{l}\text { Clases medias y altas: Valores fuertes: re- } \\
\text { producción y movilidad social. Clase ba- } \\
\text { jas: Valores débiles, supeditados al trabajo. }\end{array}$ & $\begin{array}{l}\text { Clases medias y altas: progre- } \\
\text { so social e individual. } \\
\text { Clases bajas: rápido abando- } \\
\text { no escolar para integrarse en el } \\
\text { medio laboral. Orientadas so- } \\
\text { bre todo a la integración. }\end{array}$ \\
\hline Trabajo & $\begin{array}{l}\text { España. Menor centralidad del valor traba- } \\
\text { jo (sobre todo a partir de mediados de los } \\
\text { 80). Ganan peso los valores instrumentales. } \\
\text { Portugal. El trabajo sigue siendo relevante } \\
\text { como medio de realización personal y de } \\
\text { promoción social. }\end{array}$ & $\begin{array}{l}\text { España. Sobre todo, a partir de } \\
\text { mediados de los } 80 \text {, orientadas } \\
\text { a los ingresos, la sociabilidad y } \\
\text { la seguridad. } \\
\text { Entre la integración y la } \\
\text { liberación. } \\
\text { Portugal. Progreso individual y } \\
\text { social. } \\
\text { Más favorables a la integración. }\end{array}$ \\
\hline Consumo & $\begin{array}{l}\text { Valores consumistas, hedonistas y de auto- } \\
\text { expresión personal. }\end{array}$ & $\begin{array}{l}\text { Gastar, divertirse y liberarse. } \\
\text { Orientadas a la liberación. }\end{array}$ \\
\hline Tiempo & $\begin{array}{l}\text { España: a partir de comienzos de los } 80 \text {, } \\
\text { valores presentistas. }\end{array}$ & $\begin{array}{l}\text { Incertidumbre futura. Vivir al } \\
\text { día. }\end{array}$ \\
\hline
\end{tabular}




\section{c. Generación 1975-1985}

Es la juventud más plenamente socializada en la cultura del consumo; cultura que, como se verá, ejercerá una enorme influencia en la conformación de sus actitudes, incidiendo sustancialmente en su relación con el ámbito laboral y el educativo. Es también la juventud con una mentalidad más presentista; la que más se desvincula por ello del pasado, y también la que menos proyecciones hace de futuro. Veamos todo ello más detenidamente.

\section{Educación: de la aspiración meritocrática a la convivencia con los pares}

Desde el punto de vista educativo, se trata de una generación que se inscribe en un periodo, el de finales del siglo pasado y comienzos del presente, caracterizado por unas elevadas tasas de población escolarizada (González-Anleo, 1999: 164-165). Situación que, al tiempo que alejaba a los jóvenes del mundo laboral, contribuía a integrarlos también cada vez más en la esfera del consumo (Martín Serrano y Velarde, 2000: 250).

En estas circunstancias, los estudios y la formación van perdiendo gradualmente importancia con respecto a aquellos otros aspectos de la vida más valorados por los jóvenes (la familia, la salud y los amigos), hasta situarse por detrás del ocio y del tiempo libre, que no deja de ganar en consideración desde 1999 hasta 2010, colocándose en esta última fecha 10 puntos por encima de la formación y de los estudios (González-Anleo Sánchez, 2010: 14-15 y 2006: 115-116; Funes, 2008: 23)72.

Este declive continuado de la formación hasta el año 2010 se vincula, tal como lo atestiguaba la encuesta de 1999, con la pérdida de importancia de los factores más relacionados con el estatus social (lo más importante únicamente para el 4,6\% de los jóvenes), con el ser útil a la sociedad (importante tan sólo para el 2,5\% de los encuestados), con la cultura (que citaba en primer lugar sólo un 7\% de los jóvenes), o con la obligación moral y social (muy importante en 1999 únicamente para el 1,7\% de los estudiantes). Pero esta pérdida del valor de la educación respondía también a que ya no era apenas apreciada como mecanismo de reproducción social, pues tan sólo el 8,7\% de los estudiantes encuestados en 1999 manifestaron seguir la

72 No obstante, en la encuesta de Juventud de 2014, ya fuera del periodo generacional aquí analizado, la importancia otorgada a los estudios subió sustancialmente. Ahora, en efecto, son bastantes más los jóvenes que consideran que los estudios representan algo muy importante para su vida $(64,8 \%)$, que los que atribuyen esta importancia al ocio y al tiempo libre $(51,1 \%)$. Aunque esta valoración sigue estando bastante por detrás de los valores que los jóvenes consideran más importantes para su vida, a saber, la familia, la salud y la amistad. Ver enlace http://www.injuve.es/ observatorio/demografía-e-información-general informe-de-la-juventud-en-españa-2014). 
voluntad de los padres o de la familia (González-Anleo, 1999: 170). La razón más importante que la mayoría de los jóvenes ofrecían para continuar su formación era el título (que situaba en primer lugar el 30\% de los encuestados); seguido, en segundo lugar, a mucha distancia, de la pretensión de conseguir un trabajo (muy importante para el 19,8\% de los jóvenes). No obstante, la relación con el título y con el trabajo era básicamente utilitaria e instrumental (González-Anleo, 1999: 170-171 y 197-198). Tampoco era demasiado importante para la mayoría de la juventud el centro educativo en la conformación de su identidad, situándose desde este punto de vista muy por debajo de la familia, del grupo de amigos, e incluso de los medios de comunicación (González Blasco, 1999: 198).

En contraste con la poca apreciación que tenían los estudiantes por la enseñanza, en relación con el logro y la conformación de su identidad, estaba la gran confianza que les merecían las instituciones escolares, hecho que por otra parte se venía repitiendo en todas las encuestas desde hacía más de dos décadas (González-Anleo Sánchez, 2010: 60-61 y 2006: 124-125; González-Anleo, 1999: 163-164). Esta confianza era sin embargo compatible con una actitud crítica hacia otros muchos aspectos de la institución. De hecho, un porcentaje significativo de los estudiantes encuestados estaba "poco o nada satisfecho" con los profesores (el 34,1\%), con los métodos de enseñanza (36,3\%), con la organización, las normas y la participación (41\%), o con la capacitación para el trabajo (27,7\%) (González-Anleo, 1999: 170). Dicha actitud, aparentemente contradictoria, que suponía dar poco valor a la enseñanza y valorar sin embargo bastante a las instituciones escolares, quizás se explique por la importancia que concedían estos jóvenes a las dimensiones más extrínsecas de dichas instituciones, tales como la relación con los pares, con los que el 92,7\% manifestaba estar "muy o bastante satisfechos" (González-Anleo, 1999: 167). En efecto, en la misma medida en que los estudiantes concedían una menor importancia al logro académico, valoraban mucho más todos aquellos aspectos relacionados con la vida que llevaban al lado de su grupo de iguales (Dubet, 2006: 159). Esta podría ser, pues, una de las principales razones de la confianza que depositaban en el sistema educativo. A lo que también podría contribuir el hecho de que aquellas dimensiones más jerárquicas y disciplinarias del ámbito escolar habían quedado bastante relegadas, por lo que incluso los estudiantes menos comprometidos con sus estudios se sentían cómodos en sus centros. Por este motivo, acaso, únicamente el $12 \%$ de los jóvenes encuestados se ubicaban en el grupo de los que pudieran denominarse "objetores escolares" (González-Anleo, 1999: 170).

En suma, si bien la dimensión educativa meritocrática seguía estando presente, por la importancia que se le concedía al título, éste se valoraba sobre todo instrumentalmente, lo que explica que al mismo tiempo se rechazasen todos aquellos aspectos institucionales que anteriormente estaban asociados al logro, y que implicaban jerarquía, esfuerzo y sacrificio, en espera de una futura recompensa. 
No obstante, en este escenario se observaban también importantes diferencias relativas a las distintas clases sociales, tal como se ponía de manifiesto en los grupos de discusión organizados por Conde en 1999. En efecto, para los jóvenes de clase media-alta los estudios todavía se vinculaban con el deseo de lograr el éxito profesional y un buen estatus social, de acuerdo con sus expectativas de clase, tal como ocurría con los miembros de la generación anterior. Aún albergaban un cierto proyecto de promoción personal y social vinculado a su formación; una cierta idea de la gratificación postergada (Conde, 1999: 32 y ss).

Sin embargo, para los jóvenes pertenecientes a las clases medias y mediasbajas, la formación se percibía cada vez menos como una actividad orientada al logro personal y social, y cada vez más en función del deseo de encontrar un trabajo que procurase los ingresos necesarios para el consumo. Estudiar no suponía, pues, para ellos una fuente de compensaciones, sólo el dinero compensaba como medio para conseguir un consumo inmediato. De ahí, que fuese también en este grupo social en el que más se simultaneasen los estudios con el trabajo, y también en el que mayor índice de fracaso escolar existía (Conde, 1999: 45 y ss). En las familias de estos jóvenes era, asimismo, en donde más se habría debilitado el modelo meritocrático, al favorecerse cada vez más el acceso rápido al mercado de trabajo (Conde, 1999: 48-49).

En Portugal la juventud de esta generación coincide también, tal como había sucedido en España, con una fuerte expansión educativa, que por otra parte ya había comenzado a manifestarse en el año 1974, pero que ahora estaba motivada y alentada, al igual que en el país vecino, por las pocas oportunidades que ofrecía el mercado laboral. Así, en 2001 el 26,9\% de los portugueses entre 25 y 29 años había finalizado estudios superiores (INE, 2001), cuando en 1970 esta cifra era sólo del 5\%. La educación dejaba así de ser vista como una garantía, tal como había ocurrido en la generación precedente, para convertirse en una ocupación y en una necesidad para dar respuesta a las crecientes demandas de un mercado de trabajo cada vez más competitivo y con menos oportunidades laborales (Carmo et al, 2014; Guerreiro y Abrantes, 2003).

No obstante, en este contexto se apreciaban importantes diferencias entre la educación superior y la secundaria. La primera se percibía en relación con la movilidad social, en una generación en la que muy pocos padres habían cursado estudios superiores (Guerreiro y Abrantes, 2003). Aunque para otros muchos jóvenes universitarios, hijos de las clases más favorecidas, se concibiese más como el camino para la reproducción social (en 2004 el 35,7\% de los estudiantes universitarios eran hijos de familias en donde, al menos, uno de los padres había cursado estudios superiores) (Pappákamail, 2005: 48).

Por lo que respecta a la educación secundaria, en donde casi un $40 \%$ de los jóvenes entre 15 y 17 años ingresaban en 2004 en el mercado de trabajo sin apenas 
cualificaciones (Guerreiro e Abrantes, 2003), se estaba convirtiendo en un lugar para estar más que para aspirar. Todo ello se traducía en una cultura educativa más orientada a la sociabilidad que a la meritocracia; sociabilidad con la que se identificaban la inmensa mayoría de los estudiantes. Así, el 97,2\% de los entrevistados en 1998, en una encuesta promovida por el INE, manifestaba estar muy o razonablemente satisfechos con la convivencia con sus colegas (Cabral y Pais, 1998).

\section{De la ética del trabajo al espíritu del consumo}

La cultura del trabajo experimenta también una importante erosión en la juventud de esta generación, en relación con sus dificultades de inserción laboral, la precariedad de sus empleos y la carencia de expectativas laborales más o menos sólidas (Conde, 1999: 26 y ss). Pero también por la prolongación de la edad escolar ${ }^{73}$. En este contexto cobran una mayor importancia otras dimensiones de la existencia, y en particular el universo del consumo, plenamente integrado en el estilo de vida juvenil. Así, en las encuestas de finales del siglo pasado y de la primera década del presente la valoración del tiempo libre y del ocio, ámbito por antonomasia del consumo, no ha dejado de crecer en detrimento del trabajo. De hecho, en 2010 ambas esferas se igualaban por primera en la valoración de muy importantes (González-Anleo Sánchez, 2010: 14-15) ${ }^{74}$.

En consonancia con esta situación, la actitud hacia el trabajo se hace cada vez más individualista, hedonista e instrumental, tal como se venía ya anunciando, particularmente desde mediados de los años 80 (González-Anleo Sánchez, 2006: 116). De este modo, los jóvenes de esta generación otorgan mucha más importancia, a la hora de valorar lo que significa triunfar en la vida, a "trabajar en lo que me gusta" (25\%), que a "lograr el éxito en el trabajo" (7,3\%) (Funes, 2008: 27). Esta actitud quizás sea el motivo de que desde los años 90 el trabajo aparezca cada vez menos entre las principales causas de felicidad para la juventud (Muñoz Carrión, 2010: 83).

Dicha felicidad se encontraba mucho más asociada a las relaciones personales que procuran otros ámbitos, y especialmente el del consumo, que interviene cada vez más en la cultura del trabajo modificando su sentido. Al menos, así lo manifestaban los integrantes de los Grupos de discusión organizados por Conde en 1999 (1999: 31), sobre todo los de clase media y media-baja. Para estos jóvenes, en efecto, el trabajo se concebía como un medio para procurar los ingresos necesa-

73 En efecto, en 1999 la mayoría de los jóvenes entre 15 y 20 años estaban estudiando, y más de la mitad de los que tenían entre 21 y 24 años (Elzo, 1999: 164).

74 No obstante, el trabajo recupera su posición en grado de importancia en 2014, posiblemente debido a la crisis (Injuve 2014: 19-20). 
rios para un consumo inmediato. Para ello era imprescindible contar con trabajos, habitualmente precarios, que se alternaban, en ocasiones, con los estudios ${ }^{75}$. En otros casos simplemente se abandonaba la formación en busca del dinero requerido para mantener un determinado nivel de consumo (Conde, 1999: 40 y ss). Esta situación representaba un cambio con respecto a las actitudes manifestadas por la juventud de la generación anterior, sobre todo la perteneciente a las clases obreras urbanas, que en 1982 afirmaban concebir el trabajo como una manera de ayudar a la familia, adquiriendo así las responsabilidades propias del mundo adulto (Beltrán, 1984: 200-201). Los jóvenes de 1999 valoran bastante menos, como se ve, todos los aspectos del trabajo vinculados al logro económico y social (Andrés Orizo, 1999: 58). Lo que comenzaban a valorar realmente era todo lo relacionado con el universo del consumo.

En Portugal la situación laboral de los jóvenes de esta generación se caracteriza por menores niveles de desempleo que en España (en el año 2000 el 14\% de los jóvenes estaba desempleado, lo que suponía 1/3 del desempleo total), pero elevados índices de precariedad laboral (Pais, 2005; INE, 2001; Smithson et al: 1998; Capucha, 1998).

Esta situación de inestabilidad y de precariedad laboral, en la que los jóvenes prolongan su escolaridad y sus procesos de formación, transitan entre empleos diversos, subempleos o incluso el desempleo, retrasa su incorporación a la vida adulta (Pais, 2005; Alves, 1998). Así, en 1996 el 80\% de los jóvenes portugueses entre 20 y 24 años, y el 52\% de los que tenían entre 25 y 29 años, todavía convivía con sus padres (Pappákamail, 2005: 45).

Todo ello hacía que la cultura del trabajo de la juventud de esta generación se erosionase gradualmente, al no poder construir una identidad laboral sólida, hacíéndose más instrumental, al asociarse con aspectos tales como el ganar dinero o tener una buena relación con los compañeros de trabajo (Pais, 2005 y 1999; Veira y Muñoz, 2004: 56). Al mismo tiempo, cobraba cada vez más importancia el universo del ocio y del consumo, tal como se podía observar en una investigación cualitativa realizada en 2002 entre un grupo de jóvenes portugueses entre 16 y 27 años pertenecientes a distintos niveles educativos. Muchos de ellos oponían la seriedad, la responsabilidad y las exigencias de la vida laboral al ambiente sociable, autónomo y alegre de los momentos de ocio, subrayando la creciente distancia y separación entre estos dos mundos de vida, y también entre las generaciones que los encarnaban (Pappákamail, 2005: 53-54).

\footnotetext{
Según la encuesta del CIS de 1997, un 10\% de los jóvenes entre 15 y 29 años trabajaban y estudiaban al mismo tiempo (Conde, 1999: 40). No obstante, una encuesta posterior, la de 1999, rebajaba esa cifra al 6\% para la población juvenil comprendida entre 15 y 24 años (Elzo, 1999: 165).
} 


\section{El consumo y el ocio como forma de celebración y de realización personal y colectiva}

El consumo emerge de este modo como una de las más importantes fuentes de identidad juvenil, tal como mostraban las encuestas de finales del pasado siglo y de comienzos de éste, en las que los jóvenes españoles se definían ante todo como consumidores (González-Anleo Sánchez, 2010: 104; Elzo, 2006: 75; López Ruíz, 2006: 345 y ss; González-Anleo, 1999: 177; González Blasco, 1999: 252; CIS, $1997)^{76}$. Para la juventud de esta generación, en efecto, el consumo se había convertido en la principal forma de expresión y de realización personal, mientras que el trabajo adquiría un carácter cada vez más instrumental (Conde, 1999: 91 y ss). Así, los jóvenes de finales de los 90 y de los primeros años del presente siglo valoraban el tiempo dedicado al ocio, y por tanto también al consumo, entre las cosas más importantes de su vida, por delante incluso de los estudios, y después únicamente de la familia, la salud, el trabajo o el dinero; dinero necesario, por otra parte, para invertir en el tiempo dedicado al consumo y al ocio (González-Anleo Sánchez, 2010: 14-15; Andrés Orizo, 1999: 58; Laespada-Salzar, 1999: 360). Tendencia que se acentúa al final de la primera década del presente siglo, cuando el tiempo libre y el ocio igualan en valoración al trabajo, y amplían su distancia con respecto a la formación y a los estudios, nada menos que en 10 puntos (Muy importantes para el $37 \%$ de los jóvenes, frente al $47 \%$ que consideraban como muy importante el ocio y el tiempo libre) (González-Anleo Sánchez, 2010: 14-15). La cultura del ocio, del tiempo libre y del consumo arraigaba así en los jóvenes de todos los estratos sociales, y especialmente en el de los más elevados, por disponer de un mayor poder adquisitivo (Elzo, 2006: 99; González-Anleo, 1999: 177).

En este contexto, se asiste a una creciente separación entre los espacios y los tiempos dedicados a la educación, al trabajo y al consumo. Separación que es menos el fruto del rechazo, que de la escisión entre estos mundos de vida. Así, a los momentos monótonos de la semana ocupados en el estudio y en el trabajo, le suceden los largos fines de semana de fiesta y de celebración ritualizada (Comas, 2003: 60 y ss; Conde, 1999: 91 y ss), en el que los jóvenes salen para "desconectar de la rutina cotidiana" (así lo manifestaba el 86\% de los encuestados en 2006) (Muñoz Carrión, 2010: 89). El consumo y el ocio otorgan, pues, a los jóvenes la oportuni-

76 En efecto, el porcentaje de los jóvenes que se definen a sí mismos como consumidores no ha dejado de aumentar a lo largo de este periodo. En 1997 el 39\% de los jóvenes entre 15 y 29 afirmaban que la juventud era muy consumidora, un 51\% que era bastante consumidora y sólo un $8 \%$ de estos jóvenes consideraba que era poco consumidora (Citado en Conde, 1999: 86). Dos años más tarde, en 1999, la cifra de jóvenes entre 15 y 24 años que se definían a sí mismos como consumidores se había elevado por primera vez al 46,4\% (Elzo, 1999: 177); 6 años después- en 2005- este porcentaje era ya del 59,8\%, (Elzo, 2006: 75). 
dad de liberarse de las constricciones que imponen las esferas de la educación y del trabajo, llenando la vida con nuevos sentidos (Shir-Wise, 2018: 8 y ss).

La noche es precisamente el escenario por antonomasia de esta celebración gozosa; el momento en el que la juventud se siente más libre; cuando se apropia de su tiempo para hacer algo diferente (Ramos y Benedicto, 2016: 355; Pallarés y Feixa, 2015: 31 y ss; Funes, 2008: 139; González Blasco, 1999: 227). Por eso, la mayoría de los jóvenes asocian ese momento del día con una forma de vivir "especial y propia" (González-Anleo Sánchez, 2010: 246; Funes, 2008: 139). A ese tiempo de la noche y del fin de semana le corresponde el espacio de la calle. Si bien existen también otros espacios y otros tiempos en los que los jóvenes recrean sus propios mundos de vida; espacios más privados, como los de sus habitaciones, decoradas y conformadas a su gusto y medida, a donde pueden retirarse en cualquier momento del día (Feixa, 2014: 133).

Se produce así una cesura entre los tiempos y los espacios de ocio festivo, consumista y relacional, y aquellos otros mucho más rutinizados, racionalizados y normativizados pertenecientes al mundo de la educación y del trabajo (Ramos y Benedicto, 2016: 356-357). En otras palabras, la celebración festiva y consumista invita a una fusión comunitaria alegre, autónoma y libre, mientras que la vida productiva y educativa exige que se asuman más responsabilidades que limitan esa autonomía. Por ello, frente a esta realidad, la esfera del ocio consumista promete liberación, ya no de nada ni de nadie, ni tampoco a cambio de nada; sino simplemente liberarse para obtener más liberación sin incorporación, obligación, ni sanción.

A medida que la cultura del consumo adquiere un mayor protagonismo entre los jóvenes en detrimento de la ética del trabajo y de la cultura escolar, las transiciones entre la juventud y la edad adulta se van debilitando (Conde, 1999: 224). Dicho de otro modo, cuanto más aspiran los jóvenes a consumir, más consuman sus aspiraciones en este ámbito, y menos proyectan sus deseos en otros escenarios, como el laboral y el educativo. Estos escenarios, o bien son valorados por la utilidad instrumental que procuran, al ser, en muchos casos, el soporte material del ocio consumista; o bien porque posibilitan la relación entre los pares, entre aquellos que comparten un mismo estilo de vida. La cultura del consumo acabaría así por atravesar las otras dos culturas, la laboral y la educativa, llenándolas con su propia lógica y con su particular sentido.

En Portugal la cultura del consumo comienza a cobrar también un especial protagonismo a finales de los años 90 del pasado siglo, en relación con la prolongación del periodo escolar, y también con una integración en el mercado de trabajo cada vez más tardía y precaria (Pais, 2005; Smithson et al; 1998; Capucha, 1998). En este contexto, la socialización de la juventud se vinculará crecientemente al universo del ocio y del consumo, en busca de una identidad que ya no procuraban 
adecuadamente ni el mundo del trabajo ni el educativo. De este modo, las transiciones a la edad adulta se retrasan, y la juventud se dilata cada vez más (Almeida et al, 1998) en relación con los mundos de vida festivos y hedonistas de una sociabilidad celebrativa. Los jóvenes quieren así aprovechar al máximo un tiempo libre de preocupaciones y de responsabilidades, en comunión con sus iguales (Nilsen, 1998; Ferreira, 1993). Así lo ponían al menos de manifiesto cuando fueron preguntados (Pappámikail, 2011:219-220 y 2005: 45). Para ello, disponían de unos recursos financieros, que si no les posibilitaban llevar una vida totalmente independiente, al menos les permitían vivir autónomamente en comunión con sus pares (Singly, 2005: 115 y ss). Esta situación, de autonomía con dependencia, caracteriza sobre todo a los grupos sociales más favorecidos; en los menos favorecidos la autonomía y la libertad se reducen por la falta de independencia financiera (Guerreiro e Abrantes, 2003).

Esta creciente importancia de la sociabilidad juvenil vinculada al ocio y al consumo, significaba también, tal como sucedía en España, que los tiempos y los espacios juveniles más hedonistas y festivos adquirían un carácter propio, con su particular temporalidad (la noche), sus propios escenarios (los de la calle), y sus imágenes y símbolos (moda, música, tecnología). Bailar y escuchar música mientras se bebe y se convive con los pares, son las principales dimensiones que animan este universo juvenil, mucho más hedonista y celebrativo que contestatario (Pappámikail, 2011: 220 y ss). Todo lo cual implica, asimismo, una determinada manera de concebir y de vivir el tiempo.

\section{Vivir el presente sin aguardar el futuro}

La orientación temporal de la juventud de esta generación se articula fundamentalmente sobre el eje del presente. Así era al menos la percepción mayoritaria de los jóvenes españoles encuestados a finales de los años 90 y en los primeros años de la presente centuria (Muñoz Carrión, 2010: 72-73; González-Anleo Sánchez, 2010: 104; Elzo, 2006: 75; González-Blasco, 1999: 251). En efecto, 3 de cada 4 respondieron en 2005 afirmativamente a la pregunta que se les venía haciendo regularmente a las distintas generaciones de jóvenes desde los años 60; a saber, "el futuro es tan incierto que lo mejor que se puede hacer es vivir al día" (Muñoz Carrión, 2010: 72-73). Para lo cual había que contar con el dinero suficiente para gastarlo casi inmediatamente (Conde, 1999: 22 y ss; 46). Un dinero para invertir en los largos fines de semana, buscando vivir intensamente, al margen de los tiempos rutinarios del trabajo y del estudio, en un tiempo juvenil propio (Muñoz Carrión, 2010: 86-87; Comas, 2003: 60 y ss; Conde, 1999: 91 y ss). Por otra parte, tampoco el trabajo y la educación tienen ya la misma capacidad para articular otras temporalidades que no sean las del presente (Carmo et al, 2014). En efecto, tal como se 
ha mostrado anteriormente, estos universos son cada vez más instrumentales, al estar cada vez menos vinculados con la promoción y el estatus, que necesariamente implican proyecciones de futuro (Funes, 2008: 27; González-Anleo, 1999: 170). Todo lo cual empuja a vivir en una temporalidad corta pero intensa; en "presentes perpetuos" (Featherstone, 2000: 204); en momentos que parecen encerrar en un instante lo eterno (Bauman, 2007a: 52). La eternidad de una juventud que no ve rentable sacrificarse hoy a la espera de un mañana; un mañana de contornos difusos, que es mejor ir aplazando, porque ya llegará. En vez de sacrificio, pues, una moratoria (Cuzzocrea, 2018); un mientras tanto, que se resuelve en un deseo de ir aprovechando el momento presente de una juventud que se tiene y que se goza (Ramos, 2008: 123).

Esta temporalidad presentista era también compartida por los jóvenes portugueses (Pappámikail, 2005: 52). Algunos de ellos, entrevistados en 2002, manifestaron una orientación hacia el futuro poco planificada, en la que apostaban más por una reformulación constante de los planes de vida. Las respuestas más comunes a la pregunta sobre cuáles eran los planes de futuro, fueron: "vivir el presente", "prefiero no pensar a largo plazo" (Pappákamail, 2005: 52). El futuro deja de ser así algo planificado, para convertirse en una especie de presente ficticio desde el que "la incertidumbre y la imprevisibilidad del presente es desterrada", en virtud de sus múltiples posibilidades (Pais, 2003b: 123 y ss).

Quizás por esa razón, porque la juventud se sumerge en un presente abierto e intenso en posibilidades de gozarlo y de recrearlo (Pais, 1995), el 90\% de los jóvenes portugueses de entre 15 y 24 años, encuestados en 1995 por el ICS, consideraba que la vida era una agradable aventura, y no una preocupación tras otra (así lo afirmaba el 70\%). Y por esa misma razón, acaso también, una mayoría de ellos (el 87\%) manifestase tener confianza en el futuro, a pesar de vivir volcados en el presente.

En suma, para la juventud de esta generación, el tiempo está más vinculado con las vivencias que con las experiencias. Mientras que estas últimas se acumulan, gradual y progresivamente, a lo largo de la vida, las vivencias son el producto de distintos momentos, más o menos intensos y episódicos, en los que se busca condensar los múltiples deseos de expresión y de realización personal. Por ello, parece que no hay tiempo para tantas oportunidades que se brindan al sujeto para vivir intensamente (Rosa, 2016: 162 y ss). 


\section{Cuadro 6. Generación 1975-1985}

\begin{tabular}{|l|l|l|}
\hline & \multicolumn{1}{|c|}{ Valores } & \multicolumn{1}{|c|}{ Actitudes } \\
\hline \multirow{2}{*}{ Educación } & $\begin{array}{l}\text { Mayor importancia de los valores } \\
\text { instrumentales: títulos académicos, } \\
\text { sociabilidad entre iguales, sobre todo } \\
\text { en las clases bajas y medias-bajas. En } \\
\text { las medias altas, sigue valorándose la } \\
\text { educación en relación con el estatus } \\
\text { yla profesión. }\end{array}$ & $\begin{array}{l}\text { Clases bajas y medias-bajas: Estu- } \\
\text { diar para conseguir un título. Inte- } \\
\text { rás favorables a la liberación que a } \\
\text { la integración. } \\
\text { Clases medias-altas: Estudiar para } \\
\text { conseguir un buen trabajo. Repro- } \\
\text { ducir o mejorar la posición social. } \\
\text { A medio camino entre la liberación } \\
\text { y la integración. }\end{array}$ \\
\hline Trabajo & $\begin{array}{l}\text { Individualistas, hedonistas e } \\
\text { instrumentales. }\end{array}$ & $\begin{array}{l}\text { Ganar dinero para consumir, tra- } \\
\text { bajar en lo que a uno le gusta. Más } \\
\text { favorables a la liberación. }\end{array}$ \\
\hline Consumo & $\begin{array}{l}\text { Consumistas, vinculados al ocio y a } \\
\text { la sociabilidad entre pares. }\end{array}$ & $\begin{array}{l}\text { Consumir, divertirse, relacionarse. } \\
\text { Orientadas a la liberación. }\end{array}$ \\
\hline Tiempo & Presentistas. & $\begin{array}{l}\text { Incertidumbre, vivir el día a día, } \\
\text { posibilistas. }\end{array}$ \\
\hline
\end{tabular}

\section{Conclusión}

Después de haber descrito y analizado las actitudes y los valores de 3 generaciones de jóvenes españoles y portugueses en relación con los mundos del trabajo, la educación y el consumo, se puede concluir lo siguiente.

La primera generación- la de los nacidos en el periodo 1935/1945- es la que muestra una mayor valoración de la educación y del trabajo, valoración que se vincula, en la mayoría de los casos, con la reproducción de sus condiciones sociales más que con aspiraciones de movilidad. Por ello, es una generación que se mira aún en el espejo del pasado, en el que se proyecta la imagen de una familia todavía tradicional y jerárquica. De todos modos, hacia finales de los años 60 comienza a advertirse una mayor orientación hacia el futuro impulsada por el desarrollismo.

Los jóvenes de esta generación empiezan también a apreciar el ocio y el tiempo libre, aunque sólo sea como recreo y reposo para resarcirse de aquel otro tiempo dominante, que es el productivo. 
Se trata de la generación con una mayor conciencia institucional, tal como se manifiesta en su respeto por los valores vinculados a la autoridad y a la jerarquía, y por una mayor orientación a la integración que a la liberación.

La segunda generación- la de la etapa 1955/1965- integra por primera vez las 3 culturas, siendo la del consumo la que comienza a ejercer una mayor influencia en las otras dos, sobre todo en los jóvenes nacidos en los años 60. Jóvenes que protagonizarán la transición entre los valores materialistas y los postmaterialistas (Inglehart, 1990). De todos modos, hay ciertos indicios de que este proceso comienza primero en España, a principios de los años 80, y más tarde en Portugal, a partir de mediados de los 90. De esta forma, hasta principios de la década de los 80 las culturas de la educación y del trabajo mantenían todavía un significado vinculado al estatus y al logro, sin que se opusiesen la una a la otra, pues la aceptación de una cultura implicaba normalmente el rechazo de la otra, interviniendo en muchos casos factores de clase. Sin embargo, a partir de esta fecha, ambas culturas comienzan a adquirir un carácter más instrumental, por su incapacidad para atender a sus objetivos proclamados, merced a la precariedad y a la falta de expectativas laborales. En este contexto comienzan a ser mediadas por los valores del consumo, hecho al que también contribuye la prolongación de la edad escolar. Simultáneamente, se observa un cambio en las concepciones del tiempo, imponiéndose crecientemente los valores del presente. Un presente vinculado a las actitudes hedonistas de una juventud que quiere vivir su vida cada vez más intensamente.

Toda esta situación prefigura los valores dominantes en la siguiente generación, la de los jóvenes nacidos en el periodo 1975-1985. En ella se impone definitivamente la cultura del consumo sobre las otras dos culturas, rompiendo el equilibrio, ya seriamente resquebrajado en la juventud que había nacido en los años 60 . En efecto, debido a la débil integración que procuran las esferas de la educación y del trabajo, cada vez menos vinculadas a los valores del logro y del estatus, y al auge del universo del consumo, con el que se identifican mayoritariamente los jóvenes, ambas culturas serán penetradas por la del consumo, adquiriendo una dimensión esencialmente instrumental. Dimensión que se relaciona fundamentalmente con los ingresos y la realización personal, en el caso del trabajo; y con las redes de amistad entre pares que comparten un mismo estilo de vida, en el de la educación.

Como consecuencia de todo ello, se produce una cesura entre las tres culturas analizadas. Cesura que se escenifica en la oposición entre el tiempo hedonista y expresivo del consumo, y el más rutinizado, normativizado y racionalizado del mundo productivo y educativo, cada vez más vacío de sentido. Esta creciente escisión entre la esfera institucional y la relacional; entre la que apela más a la incorporación y la que lo hace sobre todo a la liberación, se pone de manifiesto en el deseo de la juventud de vivir al margen de las ataduras institucionales, en comunión 
inmediata con sus iguales. Y se materializa en la manera que tienen los jóvenes de habitar los espacios y de vivir el tiempo. Un tiempo con un significado propio, que tratan de aprovechar intensamente sin preocuparse demasiado por el mañana.

La erosión de los valores institucionales vinculados a la intregración, y la consolidación de aquellos otros más relacionados con la liberación conlleva, asimismo, la pérdida de sentido de las dimensiones más jerárquicas y disciplinarias basadas en la autoridad. Ahora bien, este declive de la autoridad, que puede observarse en distintos escenarios de la sociedad, no ha hecho desaparecer, como luego se verá, otras formas de control, tal como puede apreciarse en diferentes ámbitos, y particularmente en el escolar. 



\section{CAPÍTULO IV \\ LA EROSIÓN DE LA AUTORIDAD Y LAS NUEVAS FORMAS DE CONTROL}

El problema de la educación en el mundo moderno se centra en el hecho de que, por su propia naturaleza, no puede renunciar a la autoridad ni a la tradición, y aun así debe desarrollarse en un mundo que ya no se estructura gracias a la autoridad ni se mantiene unido gracias a la tradición (Arendt, 2003b: 298).

\section{INTRODUCCIÓN}

Para comprender adecuadamente el descrédito de la autoridad en los diferentes escenarios de las sociedades actuales, será preciso considerar, en primer lugar, qué significado ha tenido este concepto en la tradición occidental, para entender después las razones de su progresivo declive en la Época Moderna. A todo ello estará dedicada la primera parte de este capítulo.

En la segunda, se analizarán los distintos ámbitos sociales en los que la autoridad goza de poco prestigio. Mostrando como este desprestigio ha ido acompañado en todos estos ámbitos, pero particularmente en el educativo, que se toma como ejemplo, de la emergencia de otros principios que apelan a la participación, a la autonomía y a la liberación de los sujetos, pero que sin embargo suponen la instauración de otras formas de control.

\subsection{LA AUTORIDAD Y LA TRADICIÓN EN EL MUNDO PREMODERNO}

El concepto de autoridad estuvo íntimamente unido al de tradición en el mundo romano antiguo, la civilización que hizo de ambos conceptos una de sus principales señas de identidad. Los griegos, que tantas cosas por otra parte legaron a los romanos, desconocían sin embargo el sentido que aquellos atribuyeron al término autorictas. Tal es así, que el historiador griego Dión Casio, cuando estaba escribiendo su historia de Roma, no encontró ninguna palabra en lengua griega que hiciese justicia a la romana autorictas (Arendt, 2003b: 164-65). 
Qué sentido tenía, pues, para los romanos la palabra autorictas, y por qué estaba tan estrechamente unida a la tradición.

En el mundo romano la autoridad se diferenciaba claramente del poder, porque la primera comportaba legitimidad para quien o quienes la detentaban, mientras que el poder iba asociado al uso de la fuerza ${ }^{77}$. El ejercicio de la autoridad implicaba también unas relaciones esencialmente jerárquicas y desigualitarias; jerarquía y desigualdad que no se cuestionaban, al ser consideradas legítimas por quienes participaban en ellas. Por ello, la autoridad no conllevaba el uso de la violencia. Pero tampoco se basaba en el diálogo, pues quienes la reconocían aceptaban previamente los principios y las normas que la sustentaban (Kojève, 2005: 36 y ss; Arendt, 2003b: 147).

La autorictas romana, así concebida, estaba estrechamente unida a la tradición; tradición que comenzaba con la fundación de Roma- ab urbe condita-, hecho originario del que derivaban su sentido todos los acontecimientos posteriores, al remitirse a aquel origen (Revault D’allonnes, 2008: 73). No obstante, esta tradición no se petrificaba en el pasado, sino que actuaba desde allí, tratando de mejorar el presente y el futuro. De este modo, otorgaba estabilidad al mundo, pero también lo renovaba cuando éste atravesaba por momentos de crisis. Las instituciones y las personas que asumían dicha tradición, educaban en ella a los más jóvenes, investidos de la autoridad que aquella les confería (Neraudeau, 1984: 398-99).

Después de la caída de Roma, la Iglesia Cristiana asumió la autoridad, aunque lo hizo, en parte, en nombre de otra tradición, la vinculada a la muerte y resurrección de Cristo (Arendt, 2003b: 199). En este contexto, la autoridad pasó a ser entendida como servicio.

A partir de la Edad Media este concepto de autoridad y de tradición irá declinando progresivamente con la emergencia de un Novus Ordo Seclorum que extraerá su legitimidad de principios inmanentes.

\subsection{EL DECLIVE DE LA AUTORIDAD Y DE LA TRADICIÓN EN EL PENSAMIENTO EDUCATIVO MODERNO}

La autoridad y la tradición, tal como fueron entendidas en el mundo premoderno, comenzaron a declinar en los siglos XVI y XVII, en medio de una serie de acontecimientos que dieron origen a la Época Moderna. Nos referimos, en el campo político, a la creación de los Estados Absolutos; en la esfera religiosa, a la Reforma, y en el ámbito del pensamiento, a la filosofía cartesiana y a la ciencia moderna.

77 De hecho, la raíz del término autorictas, augere -aumentar-, sugiere precisamente que la autoridad le otorgaba al poder una mayor dignidad, y por tanto también una mayor aceptación. 
El Estado Absoluto, al impulsar las conductas y las normas de la civilidad cortesana (Elías, 1993a: 115 y ss), favoreció la creación de un programa educativo de carácter humanista y universalista, orientado a civilizar a la infancia, sobre todo la perteneciente a la nobleza y a la burguesía. Un programa que se remitía todavía a la tradición, integrada por las formas de vida aristocráticas-cortesanas y por la cultura greco-latina, en la que los adultos, con la autoridad que aquella tradición les confería, debían de educar a los más jóvenes (Durkheim, 1992). Y sin embargo esta corriente portaba ya en su seno ciertos elementos que prefiguraban la cultura moderna, y que suponían un cuestionamiento de la tradición y de la autoridad. El protagonismo sin precedentes que adquirían los que habían de ser educados, en virtud de una creencia casi infinita en la bondad y en la perfectibilidad de la naturaleza humana, se situaba en esta dimensión. Como también lo estaba su consecuencia más inmediata; a saber, que el educador había de conducir a aquellas naturalezas, alentándolas suavemente, apelando sobre todo a la razón, común a infantes y adultos, con el ánimo de despertar en los primeros todas sus potencialidades (Garin, 1987: 145 y 78).

Desde esta perspectiva, el peso de la tradición y el de la autoridad de aquellos que actuaban y hablaban en su nombre, fue aligerándose, a medida que cobraban una mayor importancia quienes habían de recibirla conforme a sus particulares naturalezas e intereses. Se inició así un camino que habían de recorrer mucho más tarde pedagogos de la talla de Rousseau o de Pestalozzi, que cimentaron el pensamiento educativo moderno (Huizinga, 1987: 328).

La ciencia y la filosofía cartesiana colaboraron también en el descrédito de la autoridad tradicional, al proponer otro concepto de verdad ajustado a criterios científicos y racionales. La experimentación y la racionalidad de una mente introspectiva puesta a prueba en la confrontación consigo misma, se convirtieron en el principal criterio para admitir dicha verdad (Arendt, 1998: 301 y ss). Las tradiciones y las creencias que no se ajustasen a ese nuevo paradigma quedaban excluidas de aquella noción de verdad, no pudiendo ser el fundamento de ninguna autoridad. El pensamiento científico y el filosófico habían así expropiado el concepto de verdad del ámbito del sentido común, del mundo que tenían en común todos los hombres, y en el que los adultos tenían la responsabilidad de introducir gradualmente a los más jóvenes, por medio de la autoridad de la que aquellos estaban investidos. La nueva verdad ya no estaba sustentada, sin embargo, por los guardianes de la tradición, se relacionaba ante todo con un proceso lógico al alcance de cualquier sujeto racional, por poco iniciado que estuviese.

En una dirección parecida actuó el protestantismo. Dicha corriente religiosa creó, como se sabe, un nuevo ethos que elevó el trabajo a principal medio de salvación (Weber, 1998: 162 y ss). Con arreglo a esta nueva mentalidad, la finalidad de 
la educación ya no será introducir en una determinada tradición a los más jóvenes, bajo la autoridad y la orientación de los adultos. Una tradición de carácter cristiano, aristocrático e improductivo. Antes bien, la educación estaría encaminada a partir de ahora a formar en la fe, en la administración y en el buen gobierno, y también en el modo obtener los bienes materiales para el adecuado sustento del pueblo (Lutero, 1961a y b).

Los pedagogos reformistas, y en particular Comenius (1592-1670), el principal de todos ellos, se propondrán este objetivo, profundamente imbuidos del espíritu cartesiano (Comenius, 1976: Prólogo XX) y del de la ciencia Moderna. "Para educar a la infancia"- escribió- bastará con disponer "del tiempo, los objetos y el método" (Comenius, 1976: 51-52). Un método racional, ya que racionales son también los seres humanos y la propia naturaleza. De ella habrá que tomar, pues, "el arte de aprender y enseñar todas las cosas" (1976: 53). Con una finalidad principalmente material y utilitaria. Las escuelas no serán así otra cosa que "talleres destinados a los trabajos". Talleres en los que el maestro "hace ver con facilidad" al discípulo "la aplicación que en la vida común cotidiana tiene todo lo que le enseña" (Comenius, 1976: 80 y ss; 116).

La preocupación de los pedagogos humanistas por socializar a la juventud en normas y reglas civilizadas, por medio de la autoridad del maestro, cedía aquí ante la enorme importancia concedida a la razón del que aprende, por muy inmaduro que éste fuese. Importancia con la que estaban de acuerdo los humanistas, aunque en su caso esa importancia se mitigase por la necesidad de introducir a la infancia en el mundo de sus mayores, para lo cual había que contar con la autoridad de éstos. Esta preocupación estará ausente de la pedagogía reformista, para la que la razón- común a adultos e infantes- era modelo y guía. "No hay que guiar con voces, cárcel o azotes a la criatura racional- escribe Comenius-, sino con la razón" (1976: 23). La confianza depositada en la racionalidad humana era, en efecto, tan grande, y la sospecha del mundo externo tan importante, que se desaconsejaba toda disciplina que no procediese de la voluntad misma del sujeto. No hay, pues, que obligar por "externa urbanidad" -dice Comenius-, sino auto-obligarse para reprimir la "disposición interna y externa de nuestras pasiones" (Citado en Capitán Díaz, 1984: 486-487).

La pedagogía reformista cuestionó así la fuente anterior de la autoridad, que se irá desplazando progresivamente del mundo de la tradición, representada por los adultos, al de la naturaleza y al de la ciencia, y también al de la racionalidad de los propios sujetos que aprenden. "No se debe enseñar nada por la mera autoridad, sino que todo debe exponerse mediante la demostración sensual y racional", escribió Comenius (1976: 87). Los pedagogos de la reforma cuestionaron también la autoridad al establecer que la finalidad del saber ya no estaba en empaparse de 
la tradición que la legitimaba; de aquel "fárrago de palabras, frases, sentencias y opiniones tomadas de los autores", que eran la medida del ser humano culto y civilizado, "sino (en) abrir el entendimiento (a) las cosas" (Comenius, 1976: 85).

La erosión de la autoridad tradicional no se consumó, sin embargo, en un breve espacio de tiempo. Su declive fue acompañado de aquel otro que experimentó el proyecto civilizatorio moderno (Elias, 1993a). Dicho proyecto implicaba la intención de reformar al sujeto para introducirlo en la colectividad, despertando a un tiempo su conciencia social e individual (Dubet, 2006: 44); el deseo de ser y la necesidad de pertenecer. La civilidad humanista representó la primera etapa de este proceso, ya que aspiraba a construir sujetos racionales y autónomos, a través de su inmersión en la cultura civilizada, bajo la atenta mirada de los adultos. Aunque para ello fijase la atención en una naturaleza infantil, considerada esencialmente racional y buena, se proponía someterla a aquel programa civilizador, para su efectiva educación y liberación. En esta medida, todavía precisaba apelar a la tradición y a la autoridad. Esta apelación fue cada vez menos necesaria, como antes se ha mostrado, en la pedagogía de la Reforma, mucho más centrada en el individuo como sujeto de razón, que en la tradición, rechazada por ser fuente de falsedad y mera imposición.

No obstante, este modelo de tradición vinculado al mundo de la civilidad aristocrática siguió perviviendo en autores como John Locke (1632-1704). Su pensamiento estaba bastante en consonancia con la mentalidad de la burguesía de su época, y también con la de la aristocracia, especialmente a partir del momento en el que ésta comenzó a tejer lazos matrimoniales con aquella (Stone, 1990: 175).

Por un lado Locke continuó afirmando la primacía de la naturaleza infantil, esencialmente racional y buena, considerando que la maldad era únicamente obra del mundo (Locke, 1982: 223-224). Y creyendo también que dicha naturaleza sólo podría ser conducida viendo "en qué sentido se inclina la estructura natural de su espíritu" (Locke, 1982: 176 y 281). Por medio siempre de métodos racionales (Locke, 1982: 192). Todo lo cual otorgaba un mayor protagonismo a la infancia con respecto a la edad adulta.

Si éstos, los adultos, y particularmente los padres, tenían alguna autoridad conferida, era sólo de modo transitorio y limitado, mientras los hijos no tuviesen la facultad de razonar por ellos mismos (Locke, 2006: 80). Pues "una cosa- escribió Locke- es el deber de honrar, respetar, agradecer y asistir a los padres, y otra requerir de los hijos obediencia y sumisión absolutas" (2006: 87). Tal sumisión sería contraria a los seres humanos, que por condición natural son libres e iguales (Renaut, 2002: 221). Y si bien -afirma Locke- "los niños no nacen en este estado de igualdad...a él están destinados", una vez alcancen la edad de la razón (Locke, 2006: 78). En conclusión, escribe Locke: 
La libertad natural y la sujeción a los padres son cosas compatibles y están las dos fundadas en el mismo principio. Un niño es libre en virtud de que su padre lo es; y es gobernado por el entendimiento del padre hasta que alcanza a poseer la capacidad de entender por sí mismo (...). Dejarlo a rienda suelta, sin cortapisa alguna a su libertad, antes de que posea esa razón que pueda guiarlo, no es concederle su privilegio natural de ser libre, sino arrojarlo entre las bestias y abandonarlo a un estado tan miserable y tan inferior al hombre como el de aquéllas (2006: 82 y 84).

Este hecho, y no otro, justifica la autoridad que los padres ejercen sobre los hijos, más por "privilegio de los hijos y por deber de los padres que (por) una prerrogativa del poder paternal". Por ello, este "poder de mando termina cuando termina la minoría de edad" (Locke, 2006: 87 y 89). La autoridad que aquí se invoca es, pues, en muchos aspectos ya plenamente moderna.

Y sin embargo hay también en su pensamiento aún elementos tradicionales que se manifiestan en una firme voluntad de educar y de socializar a la infancia en la civilidad cristiana y aristocrática, identificada con la alta cultura. Desde este punto de vista, son los adultos los que, provistos de la necesaria autoridad, tendrán la responsabilidad de introducir gradualmente a la infancia en el mundo, frenando sus impulsos naturales y borrando también sus imperfecciones, que son la huella del pecado original (Rénaut, 2002: 261).

De este modo, en el pensamiento educativo de Locke conviven aquellas dos dimensiones constitutivas de la civilidad. Por una parte, la intención de educar al caballero, inculcando "hábitos y buenas costumbres". Por la otra, la de instruir al infante, para que "siga solamente lo que su razón le dicta" (Locke, 1982: 54-55 y 281). Desde una perspectiva, se trata de formar al futuro adulto mediante el ejemplo y el trato con sus mayores (Locke, 1982: 103); desde la otra, la finalidad es despertar todas las potencialidades naturales de la infancia. Pero una tarea no puede completarse sin la otra. Es más, la primera cobra más importancia, si cabe, porque "sin virtud, sin la ciencia del mundo, sin la urbanidad- afirma Locke- en ninguna parte de la tierra podrá encontrarse el hombre cabal y digno de estima" (1982: 167). Dicho de otro modo, toda conciencia autónoma y racional ha de ser, necesariamente, la conciencia de la persona civilizada.

Este equilibrio entre la esfera subjetiva y la mundana se acabará quebrando en favor de la primera en la pedagogía rousseauniana, todo lo cual acabará erosionando la dea de autoridad.

La obra de Jean-Jacques Rousseau (1712-1778) emergió en el contexto social de la nueva sensibilidad burguesa vinculada a una concepción de la familia articulada alrededor de los esposos y de los hijos. Sobre estos últimos se focalizará crecientemente la atención, procurándoles una educación apropiada a su edad, al 
margen de los espacios de sociabilidad del mundo adulto (Stone, 1990: 219; Ariès, 1987: 529 y ss; Shorter, 1977: 279-280). La burguesía será, precisamente, la más receptiva a sus obras, particularmente las que se popularizaron a partir de comienzos del siglo XIX (Cook, 2004: 29-30; Robertson, 1994: 461; Stone, 1990: 256).

La pedagogía rousseauniana, tal como aparece en su principal obra educativa, el Emilio (Rousseau, 2002), marca el inicio definitivo de un modo de pensar la educación que es ya decididamente moderno. En ella cobra un especial protagonismo la infancia, a la que se pretende apartar de un mundo que se considera el origen de casi todos los males ${ }^{78}$. "Todo está bien al salir de las manos del autor de las cosas: todo degenera entre las manos del hombre", escribió en una de sus frases más célebres (Rousseau, 2002: 37). El mundo, así concebido, representaba, pues, para él el pasado que había que borrar, para construir un ser humano nuevo a partir de una naturaleza primigenia, esencialmente buena y con enormes posibilidades: "observad la naturaleza- dijo- y seguid la ruta que os marca. Ella ejercita continuamente a los niños" (Rousseau, 2002: 55).

Mientras que Locke pretendía formar al ser humano adulto sin renunciar a la infancia; Rousseau se propone educar a ésta sin pensar en aquél. "Hay que considerar al hombre en el hombre, y al niño en el niño", afirmó. La meta es, pues, la infancia misma: "dejad que la infancia madure en los niños" (Rousseau, 2002: 104 y 126). Al adulto no le corresponde, por lo tanto, ni ordenar, ni dirigir la educación del infante. No tiene autoridad ni capacidad para ello. "Raramente os toca proponerle lo que debe aprender -escribió Rousseau-; es a él a quien corresponde desearlo, buscarlo, hallarlo" (2002: 263). La infancia misma es, en efecto, quien debe orientarse, guiada por su propias necesidades e inclinaciones naturales, alejada del contacto con los adultos; aprendiendo únicamente de su experiencia en estrecho contacto con las cosas de la naturaleza. "Acordaos- afirma Rousseau- de que, en todo, vuestras lecciones deben estar más en hechos que en palabras; porque los niños olvidan fácilmente lo que han dicho y lo que se les dice, pero no lo que han hecho ni lo que se les hace" (Rousseau, 2002: 135).

El pasado, con todo su acervo social, cultural y simbólico, queda por tanto completamente desprestigiado, y con él la autoridad que se legitimaba por su vinculación con esa tradición anterior, en nombre de la cual los adultos se dirigían a los más jóvenes. En su lugar, emerge una naturaleza infantil plena de bondad y de potencialidades, que no reconoce más fuente de verdad que la que procede de su propia experiencia práctica en interacción con su entorno natural más inmediato.

Rousseau está pensando en el mundo de la Corte, con todo su boato y ornamento, presidido por una sociabilidad densa y llena de rituales que reprimirían los sentimientos (Elias, 1993b: 153). 
El pensamiento de Rousseau dejó una profunda herencia, que fue recibida por las más diversas corrientes ideológicas, desde las liberales hasta las socialistas y anarquistas, y también por movimientos pedagógicos como los de la Escuela Nueva y la Escuela comprensiva, e incluso por las órdenes religiosas (Luzuriaga, 1994; Manacorda, 1987; Bowen, 1985 III; Dietrich, 1976; Dommaget, 1972). Con justicia se puede decir que sentó las bases definitivas de la pedagogía moderna, para la que es una referencia indiscutible.

Uno de los más destacados representantes de dicha pedagogía fue el filósofo y pedagogo Norteamericano John Dewey (1859-1952). Dewey quería integrar su propuesta educativa en el contexto de la sociedad democrática e industrial (Dewey, 1995: 107). Para ello propuso un programa pedagógico que era deudor en muchos aspectos de las ideas rousseaunianas. En efecto, al igual que Rousseau, él también hizo de la infancia la principal protagonista de la tarea educativa. Una tarea que, dijo, "debe empezar con un estudio profundo de las capacidades, intereses y hábitos del niño" (Dewey, 1908: 4). Y lo mismo que aquél, concibió el aprendizaje como una actividad fundamentalmente práctica, en la que el propio sujeto descubre sus propios intereses y capacidades (Dewey, 1995: 138 y 233; 1908: 7). Por lo que consideró también que el pasado, con todas sus tradiciones, no debía ser tenido en cuenta en el proceso educativo. "Mantener vivo el presente- afirmó- es la función de la materia educativa". Porque, en efecto, si toda "educación es una constante reorganización o reconstrucción de la experiencia”, ¿para qué contar con un conocimiento previo, si éste se construye cada vez que uno se interesa por lo que hace cuando está haciéndolo? (Dewey, 1995: 73).

¿De qué sirven entonces las jerarquías, si nadie realmente está en una posición superior por lo que a la enseñanza y al aprendizaje se refiere? ¿Para qué hacer, entonces, diferencias entre las edades, cuando "la infancia, la juventud y la vida adulta, se hallan en el mismo nivel educativo, en el sentido de que lo que realmente se aprende en todos y cada uno de los estadios de la experiencia constituye el valor de esa experiencia” (Dewey, 1995: 73. Cursivas del original). Nadie está autorizado, pues, para imponer nada desde fuera, sea éste padre o maestro (Dewey, 1995: 97-98). La única disciplina posible es la que nace de la propia voluntad del sujeto, cuando éste se interesa por lo que está haciendo (Dewey, 1995: 116). La autoridad debe quedar, pues, al margen de la actividad educativa.

El pensamiento educativo de Dewey tuvo un gran impacto en algunas de las más importantes corrientes educativas progresistas, y en especial en el movimiento de la Escuela Nueva (Bowen, 1985 III: 529). Pero esta influencia no sólo fue ideológica, sino también práctica, pues varias de las reformas educativas llevadas a cabo por los países occidentales después de la Segunda Guerra Mundial, tuvieron una fuente fundamental de inspiración en su obra. 
Esa influencia no fue menor en el caso del sociólogo francés Émile Durkheim (1858-1917). Durkheim pretendía, al igual que Dewey, crear un sistema educativo a la medida de la moderna sociedad democrática e industrial. Sin embargo, a diferencia de él, su objetivo no era convertir a la infancia en la principal protagonista de su propio proceso de aprendizaje, sino tratar de que ésta tomase conciencia de su pertenencia social, para construirse de una forma autónoma y libre. Su preocupación era fundamentalmente de carácter socio-moral. Se había impuesto, en efecto, la inmensa tarea de reemplazar la vieja moral, vinculada al mundo premoderno, por otra más ajustada a la sociedad democrática e industrial. "Antiguos deberesescribió- habían perdido su fuerza de imposición, sin que se viesen aun claramente y con mirada segura cuáles son nuestros nuevos deberes". Esta nueva moral debía "despertar la fe en un ideal común", que vinculase estrechamente a los miembros de la sociedad (Durkheim, 2002: 99-100). La escuela pública sería la encargada de propagar esta nueva moral entre los miembros más jóvenes de la comunidad, para que éstos la sintiesen como propia, como la condición imprescindible para llegar a ser sujetos racionales, iguales y autónomos (Durkheim, 2002: 107 y 217).

Ahora bien, esta tarea no podía emprenderse con el sólo concurso de una pedagogía centrada básicamente en el alumno. Se requería de alguien provisto de la suficiente legitimidad para comunicar esa moral a la infancia y a la juventud de una forma racional (Durkheim, 2002: 71). Ese alguien no podía ser otro que el docente. Era él quien, como representante de la sociedad, tenía que sentir "la autoridad que debía comunicar"; Él era quien, en efecto, debía creer "en su cometido y en la grandeza de su tarea" (Durkheim, 2002: 132). Y era él quien, asimismo, tenía que hacer ver a sus discípulos que la autoridad a la que se someten, y en nombre de la que él habla, no era el fruto de ningún poder arbitrario, sino que emanaba de una realidad superior, que a todos obliga porque a todos libera; una realidad que no era otra que la sociedad, que por ello debe ser comprendida y sentida como propia (Lukes, 1984: 126). En palabras de Durkheim, "el individuo se somete a la sociedad, y esta sumisión es la condición de su liberación” (Durkheim, 2000: 96).

El proyecto educativo durkheimiano significaba, así, la perfecta conciliación entre la dimensión institucional y la individual. La que exigía incorporación, y por tanto el reconocimiento de una determinada autoridad institucional, y la que, a través de esa incorporación, hacía posible la construcción de una identidad más autónoma y libre, menos dependiente de los lazos comunitarios. En él se aunaban, pues, la conciencia social e institucional, por una parte, y la autoconciencia, por la otra, en cuanto interiorización de las obligaciones colectivas. Este proyecto, así concebido, se adecuaba perfectamente a las condiciones de la sociedad democrática e industrial. Una sociedad que promovía la integración, y que proclamaba al mismo tiempo la movilidad para los que se sentían llamados a competir por los mejores puestos de la colectividad. Una integración y una movilidad que suponían 
la interiorización de la ética del trabajo, como camino para lograr la autonomía, la igualdad y la justicia social (Lukes, 1984: 155).

Este proyecto tenía, pues, dos caras; la una más sacrificial, porque implicaba la sumisión a determinados imperativos institucionales; la otra más liberadora, ya que por medio de aquella sumisión los sujetos podían construirse más libre y autónomamente. Ambas caras componían también una determinada representación del tiempo, puesto que los sacrificios de cada día se hacían pensando en las gratificaciones del mañana (Bauman, 2007a: 98).

Este equilibrio entre la esfera subjetiva y la institucional, que legitimaba el ejercicio de la autoridad, fue parte esencial del ideario de la escuela republicana (Lukes, 1984: 77), y como tal representaba la definitiva culminación del programa civilizador occidental. Su vigencia se mantuvo incólume desde el final de la Segunda Guerra Mundial hasta los años 60, momento a partir del cual comenzó a declinar en un ambiente de desconfianza institucional. Una desconfianza motivada por la crisis del modelo meritocrático, aquejado de la falta de correspondencia entre las cualificaciones académicas y los puestos laborales, pero alentada también por las corrientes intelectuales vinculadas a la sociología crítica y a la pedagogía libertaria, que emergieron con gran fuerza en esta época.

\subsection{LA AUTORIDAD COMO DOMINACIÓN: LA SOCIOLOGÍA CRÍTICA Y LA PEDAgOGÍA LIBERTARIA}

A partir de finales de los años 60, en el ambiente contracultural y antiinstitucional de la época (Tort, 2009: 280; Heath y Potter, 2005: 204-205; Le Goff, 2002; Pardo, 2000; Ferry y Rénaut, 1985), pero también en el contexto del agotamiento del modelo escolar meritocrático, emergió una crítica exacerbada a la autoridad, protagonizada, en su mayoría, por una serie de autores pertenecientes a las corrientes intelectuales vinculadas a la sociología crítica y la pedagogía libertaria.

Del mismo modo que una parte de la pedagogía moderna, particularmente la de raíz rousseauniana, había atacado la tradición y la autoridad que la legitimaba, para reivindicar la construcción de un sujeto libre de cualquier atadura comunitaria. Así también la pedagogía libertaria y la sociología crítica vieron en las instituciones modernas, y en particular en las educativas, otras tantas esferas de autoridad que obstaculizaban la libre expresión de los sujetos. Bien porque reprimian sus naturalezas, únicas e incomparables, tal como afirmaban los defensores de la pedagogía libertaria (Neill, 1997; Illich, 1973). O bien porque, tal como creía la sociología crítica, construían un orden disciplinario que controlaba a los individuos, configurando una nueva subjetividad normativizada (Foucault, 1999). Estas insti- 
tuciones eran, además, según esta perspectiva sociológica, auténticos aparatos de dominación de clase, que ocultaban la desigualdad, presentándola como natural, cuando no era sino el producto de esa misma estructura desigualitaria (Bourdieu y Passeron, 2001).

Todos estos autores acabaron ejerciendo una gran influencia en el ambiente intelectual y social de la época, en el que predominaba un clima poco favorable a las instituciones (Hattam-Smyth, 2014; Urraco-Solanilla, 2013; Tort, 2009; Hobson, 2001; Sommerville, 1982: 219).

Como consecuencia de todo ello se fueron escindiendo aquellas dos dimensiones, la institucional y la subjetiva, que habían cimentado el proyecto civilizador moderno. La integración institucional dejó así de ser vista como parte de un proceso encaminado a la construcción libre y autónoma de los sujetos, para ser comprendida únicamente como una estructura autoritaria destinada a su mera dominación. Los pedagogos libertarios lo afirmaron sin ambages. "Creo- dijo uno de ellos- que es un error imponer algo por autoridad” (Neill, 1997: 105). Desde la sociología crítica la mayor profundidad de análisis estuvo acompañada también de una abierta sospecha hacia las instituciones como fuentes de dominación. "Las Luces, que han descubierto las libertades inventaron también las disciplinas", escribió Foucault (1999: 322). "Toda acción pedagógica es objetivamente una violencia simbólica en tanto que imposición, por un poder arbitrario, de una arbitrariedad cultural", afirmaron Bourdieu y Passeron (2001: 19).

Había, pues, que liberar a los sujetos de tan pesadas cadenas. Los pedagogos libertarios abogaron por devolverlos a su más esencial naturaleza, en conformidad con sus intereses y sus capacidades naturales, en comunión con sus iguales (Neill, 1997; Illich, 1973). Los sociólogos consideraron, más implícita que explícitamente, que esta libertad sólo se alcanzaría en una comunidad igualitaria y libre, sin poderes ni controles, ni tampoco diferencias de clase, en la que cada individuo pudiese expresar su subjetividad racionalmente, sin intermediaciones de ningún género (Bourdieu-Passeron, 2001; Foucault, 1999).

De este modo se fue creando, entre finales de los años 60 y la década de los 70 , un clima ideológico poco favorable a la autoridad, cuyo ejercicio se equiparó con la opresión institucional y la consiguiente anulación del sujeto.

No obstante, este descrédito de la autoridad no respondía únicamente al clima intelectual e ideológico al que se acaba de hacer referencia. Estaba también enraizado en la propia dinámica de las sociedades modernas. Una dinámica que había modificado el papel de las instituciones en distintas esferas sociales, de tal manera que su estructura y su funcionamiento, así como las normas que las legitimaban, ya no se vinculaban a la jerarquía y a la autoridad, tal como había ocurrido en la 
época precedente. Una jerarquía y una autoridad en la que, por otra parte, tampoco se reconocían ya los sujetos.

\subsection{LOS UNIVERSOS SOCIALES DEL DECLIVE DE LA AUTORIDAD}

El proceso de erosión de la autoridad, que viene gestándose desde hace ya varias décadas, tiene, tal como se ha mostrado, varias vertientes. Una de ellas se enraíza ideológicamente en el propio pensamiento educativo moderno, y también en aquél otro que, siendo crítico con él, era también su heredero. La otra vertiente se relaciona con la propia dinámica de las sociedades modernas, especialmente a partir finales de los años 60 del pasado siglo. Una dinámica caracterizada por una serie de cambios en distintas esferas, tales como la educativa, la laboral, la familiar y la del consumo, que ya no necesitan recurrir a la disciplina y a la autoridad para su regular funcionamiento, más bien podría decirse que se legitiman incluso frente a ella (Lasch, 1999: 193 y ss). En todos estos contextos, como se mostrará seguidamente, la autoridad, al menos en su forma tradicional y racional-legal (Weber, 1993: 170 y ss), carece, por ello, de bases legítimas en las que sustentarse, al no encontrar ya reflejo ni en los discursos institucionales ni en las creencias de los sujetos.

Por lo que respecta a la autoridad tradicional, ha perdido ya todo su sentido en unas sociedades, como las modernas, que se construyeron contra la tradición (Arendt, 2003b: 298). Contra la tradición, en efecto, ha emergido la rama principal del discurso educativo moderno. Y contra ella se han desarrollado también los principales órdenes que articulan las sociedades modernas, tales como el educativo, el laboral, el familiar y el del consumo. Si bien en una primera etapa de la modernidad la mayoría de estos órdenes todavía integraban elementos tradicionales que eran funcionales para la propia dinámica de las sociedades modernas (Beck y Beck-Gernsheim, 2001: 45 y ss; Lasch, 1999: 193 y ss), posteriormente, especialmente después de finales de los años 60, esta misma dinámica los hizo disfuncionales, tal como sucedió en los ámbitos de la educación, del trabajo y de la familia.

Tampoco la autoridad racional-legal goza ya del mismo prestigio. Este tipo de autoridad, que fue consustancial a las grandes estructuras institucionales burocráticas del mundo moderno (Weber, 1993: 173 y ss), no guarda ya mucha relación con los actuales universos institucionales, cada vez más ligeros y livianos, e interesados en trasladar crecientes responsabilidades a los sujetos (Bauman, 2010: 265 y 2006b: 79; Sennett, 2001: 115 y ss). Sujetos a los que se invoca apelando a su autonomía y a su iniciativa personal, para que se impliquen activamente en los distintos escenarios en los que participan (Bauman y Tester, 2002: 142-43). Una invocación que no resulta demasiado refractaria para muchos de ellos, en unas so- 
ciedades, como las de la modernidad tardía, cada vez más individualizadas (Beck y Beck-Gernsheim, 2003). Únicamente la fuerza individual del líder carismático parece gozar de un cierto predicamento. Un líder que se presenta como orientador y activador de los sujetos, y que anuncia el mensaje de la innovación, maldiciendo todo lo que recuerde al pasado, por cercano que éste sea. Este liderazgo ya no descansa, pues, en el carisma vinculado a la santidad, el heroísmo o la ejemplaridad de la persona que lo ejerce (Weber, 1993: 172 y 193 y ss), sino en la capacidad para captar el signo de los nuevos tiempos, mostrando a los demás el camino que han de seguir si quieren mantenerse siempre activos y comprometidos; si quieren ser los únicos artífices de sus vidas.

En lo que sigue, se mostrará el declive de la autoridad en diferentes ámbitos, desde el punto de vista de las dos dimensiones que la han articulado a lo largo del tiempo; a saber, la basada en la ideología, a la que apelan, para legitimarse, quienes ocupan posiciones de mando; y aquella otra relacionada con la creencia, que vincula a los dominados con los que detentan la autoridad, en virtud de su adhesión a los principios ideológicos que legitiman su posición dominante (Weber, 1993: 170). El declive de la autoridad en las sociedades actuales estaría precisamente relacionado con la erosión de estas dos dimensiones, ya que ni las instituciones se legitiman en base a ella, ni los sujetos creen ya en la autoridad como principio legítimo. Sin embargo, este declive no ha supuesto la desaparición de la dominación, sino su reaparición bajo otras formas que apelan a principios más subjetivos, y más en consonancia también con las creencias de las gentes. Principios y creencias que tienen un particular reflejo en el ámbito educativo.

\subsubsection{La crisis del sistema de autoridad meritocrático}

La idea de autoridad ha desaparecido prácticamente del ámbito educativo. Ni los poderes públicos, ni las propias instituciones académicas, que han asumido un discurso psicopedagógico claramente refractario a este concepto, legitiman su intervención apelando a este principio. Pero tampoco los jóvenes, cada vez más críticos con los aspectos más jerárquicos y disciplinarios de dichas instituciones, encontraban ya sentido alguno en la idea de autoridad.

Los poderes públicos, que en la etapa posterior a la Segunda Guerra Mundial habían impulsado el proyecto meritocrático durkheimiano, que conjugaba la igualdad y la libertad con la autoridad y la jerarquía institucional, han optado por alentar otro tipo de proyecto, que finalmente ha erosionado las bases sobre las que se asentaba la autoridad. Este nuevo proyecto era la respuesta a la crisis del modelo educativo republicano, una crisis que comenzó a ser bien palpable a partir de los años 70. En este contexto, la educación fue perdiendo gradualmente su capacidad 
para impulsar el crecimiento económico y para distribuir posiciones sociales de acuerdo con los principios de mérito y capacidad. Todo ello generó una auténtica conciencia de crisis (Coombs, 1985: 29 y ss), que desembocó en numerosas críticas, desde uno y otro lado del espectro político. Aunque con diferentes argumentos, todas estas críticas coincidían en cuestionar el programa educativo moderno, por su incapacidad para atender eficientemente a todas sus promesas (Le Goff, 2002: 98; Bowen, 1985 III: 676).

La reacción que tuvieron muchos de los gobiernos ante esta situación, fue reformar la educación, replanteando el programa educativo moderno en casi todos sus términos (Prats-Reventós, 2005: 17; Terren, 1999: 215-216; Rodríguez, 1988; Raynaud, 1983: 118). Se propusieron así una serie de medidas, legitimadas por su vinculación con el imaginario educativo moderno. Entre ellas estaban la redefinición de los saberes, para orientarlos en un sentido más instrumental y utilitario, en relación con los nuevos escenarios empresariales y laborales, extremadamente flexibles y cambiantes (OCDE, 2000: 34 y 1998: 25-39; Comisión de las Comunidades Europeas, 1993: 130). Y en relación también con las pedagogías constructivistas, focalizadas en el alumnado, al que se pretendía guiar y motivar, facilitando su aprendizaje a través de su propia experiencia práctica (Torres Santomé, 2008: 165; Laval, 2004: 92; Le Goff, 1999: 61-62).

En este contexto, los profesores dejaban de ser, como había querido Durkheim (2002: 132), los representantes de una comunidad moral que les confería autoridad, y en nombre de la cual se dirigían al alumnado. Dicha comunidad, basada en principios de orden meritocrático, ya no legitimaba a las instituciones públicas, y tampoco podía legitimar ya a los enseñantes.

Pero la deslegitimación de la autoridad no se relacionaba únicamente con unas instituciones públicas que ya no la invocaban. Se vinculaba, asimismo, con las creencias de los jóvenes, cuyas actitudes y valores eran cada vez más contrarios a este principio. En efecto, la mayoría de ellos apreciaba cada vez menos todas aquellas dimensiones de los estudios relacionadas con el estatus social, la cultura o la obligación moral y social (Funes, 2008: 23; González-Anleo Sánchez, 2005: 116; González-Anleo, 1999: 170), vinculadas con la vertiente más meritocrática, disciplinaria y jerárquica de la educación, con la que eran especialmente críticos. Valorando mucho más, sin embargo, aquellos otros aspectos vinculados con las relaciones más igualitarias y horizontales que mantenían con sus pares (GonzálezAnleo Sánchez, 2010: 60-61 y 2006: 124-125; González-Anleo, 1999: 163 y ss).

Esta situación de descrédito de la autoridad no era, sin embargo, privativa del ámbito escolar. En el mundo laboral se había impuesto desde los años 80 del siglo pasado una nueva ética del trabajo, impulsada principalmente por las instituciones políticas y los expertos en gestión empresarial, que era también abiertamente 
crítica con la idea de autoridad. Como críticos se mostraban también los jóvenes, que mantenían una actitud cada vez más instrumental y hedonista con respecto al trabajo.

\subsubsection{La ética y la cultura del trabajo postfordistas}

La actual ética del trabajo, que ha emergido gradualmente a partir de los años 80 de la pasada centuria con la pretensión de legitimar el modelo laboral y productivo postfordista, ha sido especialmente refractaria a la noción de autoridad (Boltanski y Chiapello, 2002: 115; Sennett, 2001: 115). Este modelo laboral, caracterizado por una mayor precariedad y por carreras laborales cada vez más flexibles e inciertas, reclamaba una gestión de la fuerza de trabajo más movilizadora, toda vez que las apelaciones a la anterior ética del trabajo, con sus discursos jerárquicos y meritocráticos, ya no tenían demasiado sentido ni para los empresarios ni para los trabajadores (Boltanski y Chiapello, 2002: 124-125).

Con las viejas herramientas motivacionales en desuso- afirmaban los expertos en management, principales portavoces de la nueva ética del trabajoes fundamental que la gente crea en la importancia de su trabajo, sobre todo cuando han desaparecido otras certezas y garantías (...) El orgullo suele motivar más que el escalafón tradicional o el sistema del ascenso (Moss Kanter, 1999: 70-71).

En este contexto, de declive de la carrera laboral meritocrática, se cuestionaban las estructuras burocráticas fordistas, basadas en líneas verticales de mando. Dichas estructuras resultaban ahora disfuncionales para las organizaciones productivas postfordistas, por lo que se pretendía reemplazarlas por otras menos burocráticas y jerárquicas, más flexibles y participativas (Fernández Rodriguez, 2007: 223 y ss). Era tal la obsesión por difuminar cualquier símbolo de jerarquía, que se llegaba a proponer que se suprimiese en los distintos escenarios laborales todo elemento que lo representase, "desde el tamaño del despacho al grosor de las alfombras" (Moss Kanter, 1999: 51).

Las invocaciones de los portavoces de la ética de trabajo postfordista a que se abandonasen las líneas de autoridad de viejo cuño (Fernández Rodriguez, 2007: 256), no respondían únicamente sin embargo a la intención de crear estructuras más funcionales para el nuevo modelo productivo. Se explicaban también por la necesidad de reencantar el trabajo en conformidad con los valores sociales imperantes, más individualistas y democráticos, justo en el momento en el que esta actividad podía perder su encanto anterior, debido a la creciente precariedad e inestabilidad laboral creada por el sistema productivo postfordista (Gorz, 2000). Con este propósito, los portavoces de la nueva ética del trabajo han elaborado un 
discurso que incorpora muchas de las ideas que habían articulado la ideología moderna del trabajo (Durán Vázquez, 2011: 321 y ss). Así, del mismo modo que en el ámbito educativo el discurso contrario a la autoridad se nutría del pensamiento educativo moderno, asumiendo también su propia crítica, la nueva ética del trabajo integra, asimismo, las ideología moderna del trabajo, y también la crítica realizada a dicha ideología por la contracultura, para censurar las estructuras laborales fordistas por su carácter burocrático, jerárquico y autoritario (Boltanski y Chiapello, 2002). E incluso alienante, tal como sostienen algunos de los representantes de la nueva ética del trabajo (Sérieyx, 1994: 312-313). "La era del trabajador anónimo se ha acabado- dice rotundamente uno de ellos-. Esa era pesada del trabajador casi autómata de la cadena de producción en una factoría Ford (...) Esa era ha muerto" (Peters, 2002: 46). Otros hablan abiertamente de "desalienar" el trabajo, "de forma tal que cada acto laboral sea la expresión de la voluntad y del deseo del que lo efectúa" (Aktouf, 1999: 546).

Ambos discursos, por tanto, el educativo y el laboral, se alimentan del mismo universo cultural en el que se había desarrollado la ideología educativa moderna y la moderna ética del trabajo, integrando también sus propias críticas (Le Goff, 2002: 123).

Los representantes de la nueva ética del trabajo, integrados en la literatura del management, pretenden de este modo superar las viejas estructuras jerárquicas, propias del modelo laboral fordista, para pasar a otro tipo de organización más horizontal y cooperativa, orientada a prestar un determinado servicio al cliente:

Se trataría- se dice desde esta perspectiva- de pasar de una concepción de la organización (empresa, administración, hospital, ayuntamiento) vivida como un espacio de relaciones de fuerzas entre dirigentes y dirigidos, a una nueva concepción que define la organización como un conjunto de elementos en interacción orientados hacia un objetivo: el servicio al cliente (Orgogozo, 1991: 23).

De la "moral de sujeción" se transitaría así a una activa "moral de cooperación libremente aceptada", cuando todos comprendan la meta común a la que se dirigen (Landier, 1992: 89). Una meta que "no consiste en el ascenso constante y el aumento automático de sueldo, sino en el interés por una misión y en compartir la gloria y el éxito" (Moss, 1999: 51). Para lo cual será necesario contar con alguien que anime y señale el camino a los que trabajan con un mismo objetivo. Alguien que ya no se legitimará, pues, por la posición de autoridad que ocupe en la estructura organizativa, sino por su capacidad para orientar y guiar a los que trabajan con una misma misión en un mismo equipo (Aktouf, 1999: 547 y ss). En suma, en vez de estructuras de mando y obediencia, lo que se necesitarán serán, pues, líderes (Fernández Rodriguez, 2007: 262-263; Boltansky y Chiapello, 2002: 141). Personas que orienten y guíen a sus empleados (Crozier, 1995: 65), 
comprometiéndolos en el proyecto común al que todos están llamados (Landier, 1992: 89), servir al cliente en un escenario en constante cambio (Sérieyx, 1994: 95). Este discurso, que apela al liderazgo y a la orientación, ha penetrado tanto en el mundo empresarial como en las diferentes instituciones político-administrativas relacionadas con el ámbito laboral (Martín y Serrano, 2014; Artiaga et al 2014b: 412 y ss).

No obstante, el cuestionamiento de la jerarquía y de la autoridad no sólo está relacionado con la actual ética del trabajo, se relaciona también con las actitudes y los valores de la juventud. En efecto, en un contexto de precariedad laboral, de prolongación de la edad escolar y de predominio de la cultura del consumo, la actitud de los jóvenes ante el trabajo se ha hecho cada vez más instrumental, expresiva y hedonista, y por tanto también mucho más alejada de autoridades y de jerarquías. Este hecho comenzaba ya a advertirse desde mediados de los años 80 del pasado siglo, tanto en la juventud española como en la portuguesa, tal como se ha mostrado en el tercer capítulo de la tercera parte de la presente obra. A partir de ese momento, dicha juventud empezaba a mostrar unas actitudes y unos valores ajenos a las ideas de sacrificio y de postergación de la gratificación, que comportaban la aceptación de autoridades y jerarquías. Por el contrario, el trabajo adquiría para ellos un carácter crecientemente instrumental, en relación con los recursos que proporcionaba para participar en el ocio consumista (González-Anleo Sánchez, 2010; Pais, 2005 y 1999; Andrés Orizo, 1999; Callejo, 1986). O, de modo más positivo, se percibía como un medio para el goce y la realización personal (Funes, 2008). En cualquier caso, ambas actitudes implicaban la no aceptación de demasiadas imposiciones, porque lo que se pretendía obtener, o bien estaba fuera del trabajo, o era el fruto de una actividad en la que uno esperaba disfrutar y realizarse todos los días.

En suma, tanto desde la perspectiva de la ética del trabajo como de la cultura laboral, y particularmente la de los jóvenes, la autoridad se había ido vaciando de sentido. En efecto, a los gestores empresariales y a las instituciones políticas ya no les servía para legitimar las nuevas relaciones laborales. Y la juventud no estaba dispuesta a someterse a un orden que ya no les prometía grandes beneficios futuros. Lo que querían era aprovechar su juventud consumiendo y divirtiéndose en compañía de sus pares (Ramos y Benedicto, 2016; Pallarés y Feixa, 2015; Pappákamail, 2005; Comas, 2003; Cabral y Pais, 1998). Sobre todo cuando no podían consumar sus aspiraciones de trabajar en aquello que más les gustaba (Muñoz Carrión, 2010: 83; Funes, 2008: 27). En todo caso, se trataba de no hipotecar el hoy pensando en el mañana (Ramos, 2008; Pais, 2003b). Y una manera de hacerlo era, como se ha dicho, disfrutar del ocio y del consumo al lado de los iguales. 


\subsubsection{El mundo del consumo. Persuasión y realización personal entre iguales}

La cultura del consumo fue adquiriendo un protagonismo cada vez mayor entre la juventud del mundo occidental, particularmente a partir de los años 60 del pasado siglo (Bocock, 1995: 47 y ss). Aunque los países del sur de Europa, como España y Portugal, experimentaron este proceso con un poco más de retraso, siguieron la misma senda que habían trazado anteriormente las sociedades occidentales (González-Anleo Sánchez, 2014; Pais, 1998 y 1996: 207 y ss). Dicha cultura fue alentada tanto por el discurso publicitario (Ewen, 1983), como por las actitudes y los comportamientos de los jóvenes, cada vez más vinculados a este estilo de vida (Frank, 2011; Savage, 2007; Heath y Potter, 2005).

Un estilo de vida (Chaney, 2003) que iba asociado a los valores de la autonomía y la realización personal, y que, por ello, se oponía abiertamente a todo lo que recordase a jerarquía y autoridad (Frank, 2011; Heath y Potter, 2005; Pappámikail, 2005: 50-51; Featherstone, 2000). Afirmándose, por el contrario, en experiencias mucho más vinculadas a los ritos de liberación, más expresivos e individualizados, que celebraban ante todo la salida del orden institucional. Experiencias que suponían la negación de aquellas otras más relacionadas con la integración institucional, que implicaban la asunción de algún tipo de jerarquía normativa (Bell, 1977). Los mensajes publicitarios no hacían más que reactivar todas estas experiencias a través de las imágenes que proyectaban (Frank, 2011; Featherstone, 2000).

Algo parecido sucedía con el universo de la familia, guiada por actitudes y por valores cada vez menos vinculados a la jerarquía y la autoridad.

\subsubsection{De la familia jerárquica a la democrática}

La familia occidental experimentó una profunda transformación a partir de la segunda mitad del siglo XX. Esta transformación conllevó el establecimiento de unas relaciones cada vez más democráticas e igualitarias, tanto entre los esposos, como entre los padres y los hijos (Singly, 2016 y 2007; Beck y Beck-Gernsheim, 2001).

Los imperativos vinculados a la reproducción y a la movilidad social, que en la familia de la primera modernidad todavía conllevaban la presencia de una cierta autoridad, representada sobre todo por la figura del padre, fueron cediendo gradualmente en favor de una relaciones más orientadas a la convivencia y a los afectos, en el contexto de unas estructuras familiares más horizontales, flexibles y negociadoras (Singly, 2016: 164-165; Beck y Beck-Gernsheim, 2003: 172 y 2001: 45-46; Meil, 1999: 11; Harris, 1986: 286 y ss). 
Esta nueva realidad, común a las sociedades occidentales, se advertía también, aunque con un mayor retraso, tanto en Portugal como en España desde los años 80 de la pasada centuria. En ambos países se iban consolidando gradualmente unas relaciones paterno-filiales más consensuales y menos jerárquicas (González-Anleo, 1999: 148; Pais, 1998: 378), lo que significaba que tanto jóvenes como adultos apreciaban cada vez menos los valores vinculados a la autoridad y a la obediencia (EVS, 1998 y 2008).

De este modo, tal como se ha mostrado anteriormente, la autoridad se fue erosionando en los diferentes ámbitos sociales analizados anteriormente, de forma que ni las instituciones justifican su acción en base a ella, ni los individuos le reconocen demasiado sentido.

Ahora bien, la erosión de la autoridad no ha ido acompañada de un crecimiento paralelo de la autonomía y de la libertad de los sujetos. Si por ello se entiende una mayor confianza y seguridad para elegir su propio destino, sin estar sometido a una serie de imponderables que escapan al control de uno mismo. Si en la etapa anterior de la modernidad las instituciones asumían esta incertidumbre, imponiendo a cambio sus órdenes jerárquicos y disciplinarios (Foucault, 1999), en el momento actual las jerarquías y las disciplinas ya no están tan presentes ni son tan invocadas, pero los individuos tienen que enfrentarse constantemente a nuevas situaciones que tienen que gestionar ellos mismos (Bauman, 2009: 155 y ss; 2006a: 31 y ss). De este modo, si bien el nuevo orden ya no apela como el anterior a la autoridad y a la jerarquía, institucionalmente establecidas, no deja por ello de controlar a los individuos, cuya falta de confianza y de seguridad para manejar sus vidas es el precio a pagar por la autonomía y la liberación prometidas (Ehrenberg, 1998: 147 y ss). Una confianza y una seguridad que pretenden restaurar sus supuestos liberadores, eregidos en nuevos guias que apelan constantemente a los sujetos para que busquen en su interior su propia liberación, consiguiendo ser ellos mismos.

Todo ello puede observarse en los más diferentes escenarios sociales, y particularmente en el educativo, tal como se mostrará en el siguiente epígrafe.

\subsection{DE LA AUTORIDAD AL CONTROL. LIDERAR Y ORIENTAR PARA ENSEÑAR A APRENDER}

Las instituciones educativas de la presente etapa de la modernidad ya no pueden legitimarse en base a principios de orden jerárquico y meritocrático, tal como había sucedido en la época anterior, en la que la aceptación de dicho orden conllevaba, para algunos, futuras recompensas en forma desarrollo personal y de movilidad social. Estas recompensas parecen ahora mucho más inciertas. Por ello, en 
un contexto social en el que la autoridad ya no goza de demasiado predicamento, tal como se ha visto anteriormente, dichas instituciones deben legitimarse en base a otros principios más acordes con sus nuevos objetivos y con las creencias de las gentes.

En este escenario de crisis del sistema educativo meritocrático y de su necesidad de reconfiguración apelando a otro orden de legitimaciones, es en el que han surgido con fuerza en los últimos años los discursos centrados en la orientación y el liderazgo. Discursos que han sido promovidos en su mayoría por las disciplinas psicológicas y pedagógicas (Varela, 1992), claras herederas del pensamiento educativo moderno, y a cuya difusión han contribuido también algunas de las principales instituciones políticas, tanto nacionales como internacionales. La intención de estos discursos es favorecer la eficaz integración y el progreso de los individuos dentro de la institución escolar, promoviendo su socialización en la escuela, antes que por la escuela (Gauchet, 2002: 120). Aunando así el logro escolar y el reconocimiento individual; el éxito académico y el desarrollo de cada personalidad (Singly, 2016: 144 y ss). Aunque focalizando más la atención en el sujeto, para que pueda revelar su auténtico yo, logrando construirse libremente dentro del orden institucional.

Desde este punto de vista, los discursos psicológicos y pedagógicos vinculados a la orientación y al liderazgo se corresponden con un momento en el que los principios sobre los que se había asentado el proceso de civilización, a saber, la autoconciencia del sujeto revelada por medio de su pertenencia institucional, se escinden, puesto que para despertar dicha autoconciencia, para desvelar su verdadera naturaleza, ya no se considera necesario someterla a la densidad normativa de ningún orden institucional (Singly, 2016: 130; Béjar, 2010: 342; Dubet, 2006: 43-44). En otras palabras, el individuo ya no tiene que someterse a la sociedad, como quería Durkheim, uno de los principales inspiradores del programa educativo republicano, porque esta sumisión ya no es la condición para su liberación (Durkheim, 2000: 96). Dicha liberación quiere lograrse ahora, como se dijo, a partir de su propia autoconciencia. Una autoconciencia que para manifestarse precisa de alguien que la oriente, que la guie, que la motive, pero que nunca dirija sus pasos, imponiéndole normas, o enseñándole saberes, acaso ajenos por completo a sus propios intereses. De lo que se trata, por el contrario, es de que pueda desarrollarse libremente, alcanzando así todas sus metas.

La institución escolar deja así de presentarse como una instancia disciplinaria, para constituirse en el ámbito encargado de que los sujetos puedan descubrirse, mostrarse, para así poder realizarse. La tarea de los orientadores y de los líderes no consistiría, pues, tanto en enseñar normas y saberes, como en despertar en cada uno de los alumnos el interés y la motivación por lo que hacen, promoviendo de 
este modo su aprendizaje (Bolivar, 2015). "Llevo tiempo pensando- afirma uno de los actuales gurús de la pedagogía- que empleamos nuestras mejores habilidades de liderazgo cuando tratamos con los alumnos (...) Por ejemplo, identificamos las diferentes necesidades de alumnos concretos para poder satisfacerlas y así promover su progreso" (Gerver, 2012: 117). En esta misma línea se sitúan los portavoces de la OCDE, para quienes la educación debe ser concebida como una práctica orientada a promover la personalización y la individualización del aprendizaje a través del ejercicio de un liderazgo activo y participativo por parte de los docentes (Pont, 2008 II: 25).

Es más, según sostienen los autores del Informe TALIS sobre la enseñanza y el aprendizaje, elaborado por la OCDE, los profesores que ponen a prueba su liderazgo con ideas constructivistas basadas en el aprendizaje del alumnado, son más aceptados que aquellos otros que basan su enseñanza en la transmisión directa de conocimientos (OCDE, 2009: 220). De manera parecida se manifiestan los pedagogos. Dado que la enseñanza- escriben- se orienta más al aprender que al enseñar, los profesores no precisarán ya de ningún tipo de autoridad formal para lograr este cometido (Bolivar, 2010: 13).

Este Liderazgo no sólo debe presidir las relaciones entre profesores y alumnos, sino también entre los propios docentes (Bolivar, 2011: 267; Murillo, 2006: 21). Unas relaciones que no deben inscribirse ya, por tanto, en estructuras jerarquías y burocráticas, que no harían más que obstaculizar la acción educativa. En su lugar- sostienen los pedagogos, y también algunas de las principales instituciones políticas internacionales- hay que crear organizaciones más horizontales, mucho más apropiadas para que los que comparten una misma visión de su tarea puedan relacionarse, corresponsabilizándose y comprometiéndose en la persecución de unas mismas metas (Pont, 2008: 23 y ss). En dichas organizaciones tienen que desempeñar un papel fundamental los líderes. Porque el liderazgo se pone en práctica, en efecto, de forma horizontal, a través del trabajo en equipo y la responsabilidad compartida (Bolivar, 2011: 270). Por eso los líderes- señalan los pedagogos- "no tienen autoridad posicional, su influencia deriva de la que exigen respecto de sus colegas a través de su experiencia y práctica" (Bolivar, 2011:270).

En suma, los profesionales de la educación estarían llamados a ejercer su liderazgo en todos los ámbitos en los que actúan, tanto en las relaciones con el alumnado como en las que mantienen entre ellos mismos (Bolivar, 2015). Un liderazgo que no está destinado a autorizar, sino a orientar. Con un propósito semejante; a saber, integrar a todos los individuos, para que así puedan perseguir y alcanzar todos sus objetivos académicos, en consonancia con sus intereses y sus capacidades.

Los programas de orientación cobraron fuerza, precisamente, en el sistema educativo español en el contexto de la ley General de educación de 1990 (LOGSE), 
vinculada al ideario de la escuela comprensiva (Álvarez, 2005). Como parte del desarrollo de estos programas, se crearon en todos los centros de enseñanza secundaria plazas de especialistas en psicología y pedagogía, integradas en los llamados Departamentos de Orientación (Díaz et al, 1997: 15). Dichos especialistas tenían como uno de sus principales cometidos el reconocimiento de la diversidad del alumnado, respetando su singularidad, promoviendo su desarrollo personal y fomentando sus distintas motivaciones e intereses, con el objetivo de que todos pudiesen alcanzar unos mismos objetivos académicos (Grañeras y Parra, 2009: 119; Díaz et al, 1997: 21).

Las leyes posteriores, como la LOE y la LOMCE, a pesar de su distinto cariz ideológico, han seguido considerando la orientación como un instrumento fundamental para atender a la diversidad del alumnado, favoreciendo una enseñanza adaptada a sus necesidades, capacidades e intereses. Con una misma finalidad; a saber, que todos logren alcanzar los objetivos académicos reconocidos institucionalmente (Grañeras y Parra, 2009: 119 y ss).

El discurso de la orientación integraría así dos vertientes. Por un lado, la más subjetiva, vinculada a la mentalidad individualista imperante en las sociedades occidentales, y también a los discursos críticos de la educación que se habían desarrollado durante los años 70, con su énfasis en la autonomía y la realización personal. Por el otro, aquella otra vertiente más objetiva, que se encamina a que todos los sujetos logren alcanzar las metas académicas fijadas institucionalmente (Singly, 1995).

En este contexto, la noción de Orientación se inscribe en un régimen disciplinario diferente al que había caracterizado a la escuela meritocrática. Para ésta última, la autonomía y la realización personal dependían de la integración sistémica, y dicha integración presuponía la imposición y la aceptación de un orden institucional de carácter jerárquico y meritocrático. Todo lo cual implicaba que el individuo estaba tanto más integrado cuanto más interiorizaba ese orden, incorporando las disciplinas que éste imponía como autocontroles (Dubet, 2006: 44 y ss). Las actuales instituciones académicas actúan, sin embargo, de otra manera. Quieren lograr la integración mediante el reconocimiento de la particularidad de cada sujeto (Le Goff, 1999: 53 y ss).

La Orientación presenta así un carácter un tanto paradójico. Por un lado, reconoce la autonomía y la singularidad de cada sujeto; su capacidad y su iniciativa personal para construir su propio itinerario de aprendizaje. Pero por el otro, considera que cada uno de ellos está necesitado de orientación, en virtud de su carácter todavía inmaduro e incompleto, con el fin de devolverlo a su condición autónoma original, desde la que debe poder lograr todas sus metas (Gauchet, 2002: 131). El individuo aparece así, en el contexto de este discur- 
so, con la doble condición de actor soberano y de paciente (Illouz, 2010: 237; Ehrenberg, 1998: 134 y ss, 249).

Todo ello supone un modo diferente de entender la relación académica. En efecto, ésta ya no se inscribe en un orden institucional de carácter objetivo que otorga a cada alumno una determinada identidad reconocida institucionalmente. Dicha relación tiene ahora un carácter mucho más subjetivo, pues cada individuo debe ser reconocido y valorado en su singularidad por la institución en la que se integra (Dubet, 2006: 93). Emergen así unas relaciones académicas mucho más personalizadas, en la que tienen cabida el carácter, las emociones y los sentimientos de los sujetos. Porque todos estos rasgos de la personalidad revelan una determinada forma de ser que los orientadores aconsejan tener en cuenta, con el fin de comprender las motivaciones y los intereses de cada sujeto, para poder llevar así a cada uno por el camino del éxito.

Ahora bien, una vez que los individuos han sido así liberados de sus roles institucionales, lo que queda es el modelo de la pura relación, característica de los ámbitos privados, gobernada por los sentimientos y los afectos (Giddens, 2006). Un modelo que es difícil de trasladar a un campo como el escolar, situado entre la esfera privada y la pública. En efecto, desprovista de normas públicamente reconocidas, y sin las máscaras identitarias que permiten a los individuos el trato civilizado con sus semejantes (Sennett, 2011: 326-327), la relación académica ya no tiene lugar entre actores sociales conscientes de sus particulares roles, sino entre individuos que ponen en juego legítimamente sus emociones, y que no atienden a otras obligaciones y responsabilidades que no sean las de su esfera más particular y propia. No obstante, remitidos a este ámbito, y sin otras referencias que no sean las suyas propias, los sujetos sólo pueden confiar en si mismos. Y cuando esta confianza desaparece, se inicia un proceso de búsqueda de identidad; una búsqueda para la que el sistema escolar pone a disposición de los sujetos la orientación del terapeuta.

\section{Conclusión}

En este capítulo se ha mostrado como la pérdida de sentido y de valor del concepto de autoridad en las actuales sociedades occidentales responde a diversas causas. Unas relacionadas con el propio proceso de conformación de estas mismas sociedades, que se produjo en buena medida frente a la autoridad y a la tradición que la fundamentaba (Arendt, 2003b). Otras vinculadas a las transformaciones ocurridas en las últimas décadas en diferentes escenarios sociales, como los de la familia, la educación, el trabajo y el consumo, que se legitiman en base a otros 
principios más individualistas e igualitarios, abiertamente refractarios a la jerarquía y a la autoridad.

No obstante, la erosión de la autoridad no ha significado que la dominación haya desaparecido (Lasch, 1999: 223 y ss), sino que ésta ya no se ejerce a través de un orden disciplinario basado en instituciones rígidas y jerárquicas, sino apelando a la iniciativa individual y a la propia autonomía de los sujetos, en contextos organizativos más participativos, abiertos, flexibles y horizontales, aunque también más inciertos (Deleuze, 1999). En este nuevo orden corresponde a los sujetos gestionar sus propias circunstancias, por mucho que más que crearlas las hayan heredado. Aunque ya nadie quiere reconocer ninguna herencia, y menos quienes, con el pretexto de liberar a los individuos de las pesadas cargas institucionales del pasado, no hacen más que devolverlos a su propia individualidad, desde la que prometen restaurar su independencia y su autonomía (Bauman, 2010: 215 y ss; 2007a: 98 y ss).

Ya no se necesitan, pues, personas investidas de una determinada autoridad que recuerden a los individuos cuál es su cometido institucionalmente establecido, sino de otras que los lideren y los orienten, para que de este modo tomen conciencia de que en ellos está la solución y también las posibles carencias. El discurso del liderzgo y la orientación se ha impuesto así en diferentes campos en los que las instituciones ya no pueden ni quieren legitimarse recurriendo a las normas disciplinarias del pasado, y particularmente en el educativo, tema principal del presente libro. En él, quienes lideran y orientan tratan de reactivar a los individuos desmotivados para que encuentren en sus propias inquietudes e intereses una nueva fuente de motivación desde la que puedan alcanzar determinados logros académicos. No obstante, remitidos a su propia subjetividad, los sujetos tienen cada vez más dificultades para valorarse y comprenderse fuera de sí mismos, huérfanos de otras fuentes de reconocimiento que les obliguen, pero que también les confieran un sentido más profundo a sus vidas. 


\title{
EPÍLOGO \\ ENSEÑAR PARA QUÉ, APRENDER PARA QUÉ. INCERTIDUMBRES Y PARADOJAS DE LA EDUCACIÓN EN LA SOCIEDAD ACTUAL
}

\begin{abstract}
Precisamente por el bien de lo que hay de nuevo y revolucionario en cada niño, la educación ha de ser conservadora; tiene que preservar ese elemento nuevo e introducirlo como novedad en un mundo viejo que, por muy revolucionarias que sean sus acciones, siempre es anticuado y está cerca de la ruina desde el punto de vista de la última generación (Arendt, 2003a: 296).
\end{abstract}

A lo largo de este libro hemos analizado las distintas vertientes que permiten entender la realidad educativa actual. Para ello, no hemos partido únicamente de esa misma realidad, tratando de comprenderla a partir de las propias circunstancias que la envuelven.

Hemos seguido, por el contrario, otro camino. Un camino que se ha trazado partiendo de la tradición educativa occidental. Con un doble propósito. Primero, el de contrastar dicha tradición con aquella otra que dio origen al mundo educativo moderno. Segundo, con la intención de reconstruir el proceso genealógico que ha desembocado en la manera moderna de entender la educación, que, tal como se ha mostrado a lo largo de esta obra, es el fruto de un largo proceso. Un proceso que conoció su plenitud en el periodo comprendido entre el final de la Segunda Guerra Mundial y los años 70, con el desarrollo de los sistemas educativos de masas.

A partir de ese momento se va abriendo paso otro escenario, que irá configurando el mundo de la educación tal como se conoce actualmente. Un escenario en el que confluyen diversos factores. Los relacionados con los propios sistemas educativos, que al no poder ya cumplir con las promesas que había alimentado el programa educativo moderno, se han visto en la necesidad de transformarse, legitimando dichas transformaciones a partir de un discurso emparentado con ese propio programa, pero también con aquellas corrientes que lo habían criticado abiertamente. El de los cambios experimentados por la familia, cada vez más individualista y orientada a la realización de cada uno de sus miembros, y en particular de los hijos, y cada vez menos preocupada por las transmisiones. Y, asimismo, el que tiene que ver con la socialización de la juventud. Una socialización cada vez 
menos relacionada con las trayectorias de clase, vinculadas a la idea meritocrática del logro y de la gratificación postergada. Con estas trayectorias, proyectadas hacia el futuro, ya no se identifican, en efecto, demasiado los jóvenes actualmente. Atrapados en unas realidades educativas y laborales cada vez más inciertas, y cada vez más volcados en el mundo del consumo, construyen sus biografías con un intenso deseo de realización personal en comunión con sus pares. Sin esperar, pero también sin desesperar, inmersos en una cotidianidad que, aunque incierta y con muchas sombras, procuran vivir intensamente, con el horizonte de una juventud que se percibe angosta y abierta a numerosas oportunidades de realización personal.

Todas estas circunstancias, las relacionadas con el mundo escolar, con el familiar y con el de los jóvenes, han trastocado profundamente los procesos de educación y de socialización, creando numerosas contradicciones, especialmente en el ámbito escolar, en donde concurren todas ellas.

Allí es, en efecto, donde se hace visible la voluntad que tienen los padres de procurar la mejor realización personal para sus hijos, lo que conlleva su satisfacción personal, pero también la consecución de determinados logros académicos. Allí es también a donde acuden los jóvenes para estar y disfrutar en compañía de sus iguales, concibiendo sus aspiraciones, en el caso de que las haya, más en relación con sus propios deseos personales que con metas fijadas institucionalmente. Y es allí, asimismo, en donde se integran todas estas situaciones en la situación de los propios centros académicos. Unos centros que ya no pueden cumplir con el programa meritocrático moderno, en profunda crisis, por lo que recurren a otras formas de integración legitimadas por la psicología y la pedagogía. Estas formas de integración, vinculadas al pensamiento educativo moderno, tanto en su primera versión como en aquella otra posterior más crítica, apelan constantemente a la autonomía y a la realización personal, así como al reconocimiento de la diversidad, y sin embargo tienen que ser compatibles con la pretensión de los propios centros educativos de promover una cierta homogeneidad, que haga de cada individuo un alumno como los demás.

Ahora bien, ¿ cómo conjugar estas dos dimensiones que la escuela meritocrática había integrado?; a saber, la necesidad de pertenecer para ser. En otras palabras, ¿cómo hacer posible la integración y la liberación, la diversidad y la igualdad, la pertenencia y la autonomía, la participación democrática y la integración institucional? Es aquí donde las instituciones educativas fuerzan permanentemente sus costuras.

Las fuerzan cuando quieren abrirse a las familias, para ser entidades plurales y participativas, $y$ sin embargo deben tener su propio régimen interno. Las fuerzan también cuando pretenden dirigirse a niños y a jóvenes para constituirlos a partir de un sí mismo, porque otros quieren también ser ellos mismos, y así lo quieren 
también sus padres. Y las fuerzan, en fin, porque la propia institución escolar pretende integrar a los individuos para que se conviertan en unos otros instruidos y educados, sin dejar de ser ellos mismos.

Resulta difícil enfrentarse a todas estas contradicciones y paradojas sin entrar en conflicto. El que se tiene muchas veces con los padres, y cotidianamente con el alumnado. O el que se produce, cada vez con mayor frecuencia, con las instituciones políticas, que exigen una cosa y la otra. Que la escuela siga siendo meritocrática cuando ya no puede serlo; que procure el logro académico de la mayoría del alumnado, sin dejar por ello de atender a cada sujeto ${ }^{79}$.

En medio de todas estas contradicciones actúan los docentes, sin apenas autoridad institucional para resolverlas. No la tienen, porque ya nadie los autoriza. Ni las instituciones políticas, que para responder a la crisis del sistema meritocrático se proponen cambiarlo todo, según el modelo de la adaptación permanente a una realidad que se presenta como constantemente cambiante. Legitimando dicho cambio según el discurso de la psicología y de la pedagogía, y también según el de los portavoces de la nueva ética del trabajo. No hay que enseñar, pues, lo que ya está caduco, y que además caduca permanentemente, se dice. Se trata entonces de aprender a aprender. El profesor es, pues, un guía y un facilitador, para lo cual no debe situarse ya en una posición jerárquica superior. El protagonismo del aprendizaje corresponde, entonces, al alumno.

Tampoco se sienten autorizados los profesores por los padres que, preocupados por la completa realización de sus hijos, los perciben como el obstáculo para lograr, lo que sin duda de otro modo sus hijos lograrían.

Y tampoco lo están por el alumnado, cada vez más alejado de la cultura del logro meritocrático. Una cultura que poco les dice a quienes se identifican principalmente con la del ocio y el consumo, en la que se expresan, personal y libremente, en comunión con sus pares; configurando así una identidad que se opone a cualquier intento de imposición institucional.

Esta falta de autoridad docente ya no puede ser compensada por las instituciones académicas, que por otra parte tampoco tienen voluntad de hacerlo. Su fuente tradicional de autoridad, poseer determinados saberes, es cada vez menos reconocida institucionalmente. En su lugar, sólo se reconoce su condición de guías

\footnotetext{
79 De ahí, la obsesión por los distintos informes y rankings académicos, y en particular el PISA, una y otra vez invocados para decir que se ha mejorado un poco, o que se ha empeorado, pero que, en todo caso, hay que seguir mejorando, reformando y reformulando, porque nunca se está suficientemente preparado para lo que hay que estar preparado, que es estar continuamente preparándose. He aquí la interminable paradoja.
} 
y de orientadores; una especie de coachings que asesoran e incentivan al alumnado, verdadero protagonista de su aprendizaje.

Todas las circunstancias hasta aquí señaladas configuran el universo educativo actual, complejo y contradictorio. Por ello, para analizarlo y para comprenderlo, hemos querido alejarnos primeramente de él, del presente que lo encierra en sus propias circunstancias y contradicciones, para poder después acercarnos, y ver estas mismas circunstancias desde una perspectiva más amplia, y acaso también más nueva. El resultado es el que se ha mostrado a lo largo de este libro, que ahora concluye.

No obstante, antes de concluir queremos hacer una serie de reflexiones a partir de lo que ha sido descrito y analizado, con la intención de clarificar un poco este panorama. Un panorama en el que se escuchan muchas voces, algunas de ellas críticas, otras que se presentan continuamente como innovadoras, aunque en la mayoría de los casos poco tienen de ello.

La primera de estas reflexiones nos obliga a volver de nuevo la vista atrás, e interrogarnos sobre lo que se ha entendido por educación en nuestra tradición occidental premoderna. Se trataría de ver de este modo qué es lo que hemos perdido en lo que ya nos resulta extraño, para, desde este extrañamiento, observar más claramente la particularidad de nuestras propias concepciones educativas.

Desde el punto de vista de esa tradición, ya olvidada, existía una clara diferencia entre educación e instrucción; diferencia que hoy aparece como borrosa y no demasiado comprendida.

Educar significaba, en efecto, en este contexto, empaparse de un determinado ideal de vida de la mano de los adultos, que eran quienes mejor lo conocían y lo apreciaban; y quienes, además, se proponían como modelo para transmitirlo. Bajo su dirección se trataba, pues, de integrar gradualmente a la infancia y a la juventud en este estilo de vida, observando y siguiendo el ejemplo que los adultos le ofrecían.

Educar implicaba de este modo transmitir. Y para transmitir había que convivir; había que estar con y entre los otros. Conviviendo se adquirían, en efecto, toda una serie de creencias y de prácticas; de maneras de ser, de pensar y de sentir que sólo podían ser interiorizadas y apreciadas de esta forma (Durkheim, 1985: 35 y ss). Dichas creencias y dichas prácticas se transformaban así en habitus, formas naturales de actuar, de comprender y de juzgar (Bourdieu, 2006: 170-171; 477 y ss; 2007: 85 y ss).

La instrucción, por el contrario, consistía, en la mayoría de los casos, en la adquisición de una serie de habilidades y de conocimientos técnicos, normalmente 
necesarios para el desempeño de determinados oficios. Como tal, tenía una consideración bastante menos importante. No obstante, en no pocas ocasiones, las personas instruidas eran también las mejor educadas. Lo que sólo sucedía cuando la instrucción iba asociada a un particular universo educativo que le otorgaba sentido. Fuera de este universo la instrucción tenía, como se ha dicho, un carácter más bien secundario. De ahí, el escaso prestigio que tuvo la enseñanza escolar en la mayoría de las sociedades preindustriales, como también lo tuvo el oficio de maestro, que entre los romanos podía desempeñar un esclavo bien instruido.

Todo esto comenzó a cambiar mucho más tarde, cuando la nobleza, vinculada a las Monarquías Absolutas, precisó de la instrucción para incorporarse a los puestos de la administración del Estado. Y aun así, Locke podía decir que prefería la educación a la instrucción, pues sin ella- afirmaba- ningún caballero podía considerarse digno de estima (1982: 167). Y todavía mucho después Tocqueville se mostraba escéptico con respecto a las potencialidades que los modernos atribuían a la instrucción frente al poder de la educación. "Aún estoy más lejos de creer- escribió-, como muchos en Europa, que baste con enseñar a los hombres a leer y a escribir para convertirlos sin más en verdaderos ciudadanos. La verdadera instrucción -concluyó- nace de la experiencia" (Tocqueville, 1993 II: 287-88).

Mientras que la educación estaba directa e íntimamente vinculada a la convivencia inter homines, la instrucción conllevaba normalmente el contacto con las cosas. Todo lo cual implicaba una actividad práctica y mental; hacer y razonar, lógica e instrumentalmente.

Cuando la razón comenzó a considerarse una facultad humana, natural y universal, y por ello inherente a la estructura de la mente humana, y no algo derivado de su condición social (Arendt, 1998: 310-311), se creyó también que cualquier persona, con independencia de su experiencia mundana, podía ser instruida si se empleaba el método racional más adecuado, y si se la situaba también en el mejor de los escenarios, aquel en el que se suprimiesen todas las diferencias sociales, conservando únicamente las naturales, que hacían a todos los seres humanos iguales y racionales. Cuando esto no pudiese así lograrse, se consideraba que era la sociedad, con todas sus desigualdades, que hacían a unos capaces y a otros incapaces, la causante de todo ello. Esta fue la dirección que siguió una rama importante y principal del pensamiento educativo moderno, de la que somos en buena medida sus herederos. Todo lo cual nos ha llevado a confundir la instrucción con la educación, haciendo que se hable indistintamente de una cosa y de la otra.

Y sin embargo, tal como se ha visto, la diferencia estaba clara para la tradición educativa premoderna, particularmente la que se originó en el mundo clásico antiguo. Lo que los individuos pertenecientes a esta tradición sabían, en efecto, era que la instrucción, sin la debida convivencia mundana, por medio de 
la cual se interiorizan obras, pensamientos y sentimientos, no permitía que unas personas se entendiesen con las otras, como sí se entendían las que eran cultas y educadas; porque, aun pudiendo no estar de acuerdo, sabían lo que su educación valía ${ }^{80}$. Como podían saber, asimismo, lo que valía su instrucción, si estaba de acuerdo con ese modelo educativo. Se trataba, en suma, de una relación de medios y fines.

Por este motivo, acaso, la escuela actual, a pesar de que se propone instruir y educar, instruye poco y apenas educa, porque no tiene un modelo educativo firme y claro al que remitirse. Modelo que aún tenía la escuela de la primera modernidad, y por eso no se enfrentó al mismo problema.

Este modelo era el de la sociedad industrial, jerárquica y meritocrática. Una sociedad en la que tenían sentido las trayectorias de clase vinculadas a la movilidad o a la reproducción social, y en la que las jerarquías y las autoridades que imponían las distintas instituciones sociales se aceptaban como parte del peaje que había que pagar para mantenerse o ir avanzando. Este era el mensaje que una buena parte de las generaciones de este periodo quisieron transmitir a las otras. $\mathrm{Y}$ si muchos no aceptaban recibirlo en la escuela, porque para ellos era una corta estación de paso, lo recibían en la familia y en el mundo del trabajo.

Este escenario es el que precisamente más ha cambiado, especialmente desde mediados de los años 70 del pasado siglo. A partir de ese momento, las instituciones que antes transmitían y socializaban se encontraron con muchas dificultades para hacerlo en los mismos términos, y en particular la escuela. Por esa razón ésta ha pretendido reinventarse. Ahora bien, esta reinvención, legitimada por la psicología y la pedagogía, verdaderas herederas del pensamiento educativo moderno, incluso de aquellas corrientes que lo habían criticado, es en realidad un reencantamiento. Un intento de reencantar el ámbito escolar, otorgándole nuevos significados, cuando precisamente ya no hay muchas razones para el encantamiento. Por este motivo, este discurso apenas puede generar entusiasmo entre los desencantados. Y no puede hacerlo porque, habiendo vaciado la institución escolar de su función anterior, no se ha puesto en su lugar más que la incertidumbre y el riesgo, haciendo de todo ello la principal justificación de lo que ha de enseñarse y de lo que tiene que aprenderse. No se trata, pues, ya de transmitir determinados conocimientos. De lo que se trataría, por el contrario, es de desarrollar determinadas actitudes para enfrentarse al cambio. Al cambio que rodea a los mundos del trabajo y del consumo, que son tomados como modelo y como meta.

Esta idea de la educación y de la cultura estaba enraizada en la tradición romana antigua, para la que una persona culta era la que sabía elegir a las personas con quien relacionarse, y también las ideas y las cosas (Arendt, 2003c: 345). 
Si la escuela ya no puede ni quiere transmitir, tampoco lo hace la familia. En un contexto en el que le resulta cada vez más difícil compatibilizar las funciones productivas y las reproductivas, se ve obligada a externalizar cada vez más estas últimas en beneficio de las primeras. Se convierte así en una unidad supeditada al mundo de la producción y del consumo. Como tal, permanece vinculada a las distintas inseguridades que generan estos mercados. Se organiza, además, de una forma convivencial y flexible, individualista e igualitarista, orientándose al reconocimiento individual de cada uno de sus miembros. Poco tiene ya, por tanto, que transmitir que no sea procurar la seguridad material y afectiva, sobre todo la de los hijos, razón por la cual es cada vez más apreciada y valorada por éstos.

A estas socializaciones y a estas transmisiones son también cada vez menos receptivos los jóvenes. Vinculados a sus propios espacios de socialización, articulados alrededor del ocio y del consumo, reivindican una identidad personalista, expresiva y comunitaria, y por eso mismo también opuesta a las autoridades y a las jerarquías institucionales.

Por todo ello; porque las principales instituciones de socialización poco trasmiten y socializan, al no tener ya un modelo claro al que remitirse, poco pueden también educar.

Porque la educación conlleva inevitablemente la transmisión de una determinada tradición de una generación a la otra, a través de su encuentro en los diferentes espacios de socialización. Sin este encuentro entre lo viejo y lo nuevo no hay transmisión educativa posible. No hay oportunidad de enseñar a los que aún no saben lo que deben saber para orientarse, sin perderse, en lo que será su propio mundo. La educación no es en este sentido necesariamente reproductiva, sino que puede ser creadora de algo nuevo (Arendt, 2003a: 295 y ss). Ahora bien, no se trata de la novedad que rápidamente se vuelve vieja para querer ser otra vez nueva. No es, en definitiva, la sagrada innovación que invocan los gurús de nuestras sociedades. Es aquella otra que nace de la experiencia previa de quienes han transmitido lo viejo, a cuya luz sólo lo que viene puede ser nuevo. Y puede serlo no a pesar, sino precisamente porque "se desprende de todo lo habido" (Zambrano, 1992: 14).

No hay innovación, pues, sin una previa transmisión, para lo cual hay que contar también con medios eficaces para llevarla a cabo. Para ello se requiere confianza en lo que se transmite. Y también un cierto arraigo, tanto por parte de los que transmiten como de los que aprenden.

En un mundo, como el actual, dominado por la producción y el consumo, esta confianza y este arraigo es el que precisamente falta en las instituciones encargadas de socializar, de educar y de instruir. 
De él carece la escuela, porque ya no confía en nada sólido que transmitir. Es más, con la mirada puesta fijamente en el mundo tecnológico, laboral y productivo, hace de lo voluble y cambiante su razón de ser (Bauman, 2007b: 32). Carente de esta confianza tampoco se siente muy obligada a obligar, únicamente a orientar. Por ello, se legitima cada vez más como un espacio horizontal, abierto a la participación y a la comunicación de todo el mundo, profesores, padres y alumnos; un espacio concebido más en función de quienes aprenden que de los que enseñan.

Tampoco la familia tiene ya la confianza y el arraigo necesarios para realizar esta tarea, huérfana como está de un modelo social al que vincularse. Sólo los afectos y la preocupación sin límites por la liberación de un yo, al que se percibe lleno de potencialidades, parecen vincular seriamente a sus miembros (Gergen, 1997: 230). Razones que no parecen suficientes para educar, al tener como principal referencia y medida al sujeto mismo, y no al mundo en el que necesariamente éste tendrá que integrarse.

Por todas estas razones, los jóvenes tampoco tienen demasiados motivos para confiar y arraigar, al no haber instituciones en las que se reconozcan que les den confianza y arraigo, obligándolos también en alguna medida. Tampoco contribuyen demasiado a todo ello aquellos universos, como los del ocio y el consumo, en los que se integran, y que confieren sentido a sus vidas. Si bien les permiten establecer relaciones y vivir nuevas experiencias, a través de las que revitalizan permanentemente una juventud con temores, pero también abierta a nuevas aventuras personales y comunitarias.

La juventud habita así en sus propios tiempos y en sus particulares espacios, sin demasido contacto con los adultos. Ahora bien, esta separación entre las generaciones no conduce ya a la rebeldía, porque los adultos apenas presionan a los más jóvenes tratando de inculcarles unos valores que, por otra parte, tampoco son ya tan diferentes a los suyos. Quizás por este motivo no existen en nuestras sociedades aquellos rituales subversivos de juventud que se dieron en el pasado, y que los adultos aceptaban, sabiendo ellos, y también los jóvenes, que su destino final no podía ser otro que su integración en el mundo adulto. Estos ritos de paso juveniles han desaparecido, porque ya no hay nada hacia donde transitar; no hay juventud que aprovechar, cuando ésta se estira cada vez más, ni tampoco meta a la que dirigirse, que no sea la que marca la propia juventud. Tampoco hay ya demasiadas razones para la confrontación ideológica.

Lo que se observa, por tanto, no es oposición, sino ante todo distancia y separación. Una separación que muchas veces conduce a la sospecha, y otras al alboroto, cuando la juventud percibe la intromisión de los adultos en sus propios mundos de vida. En otras ocasiones, son los propios jóvenes los que piden que se 
les escuche, y no tanto que se les comprenda, porque en realidad ya no quieren ser comprendidos. Para una cosa y para la otra están los orientadores y los terapeutas. Ahora bien, si la única promesa de dicha orientación es la liberación, no se sabe muy bien de qué, por qué y para qué, los jóvenes preferirán la que experimentan cada día en sus propios universos, al lado de sus colegas. 



\section{BIBLIOGRAFÍA}

Ago, R. (1996). Jóvenes nobles en la época del Absolutismo: autoritarismo paterno y libertad. En G. Levi.; J.C Schmitt (dirs.). Historia de los jóvenes (Vol. I) (pp. 305353). Madrid: Taurus.

Aktouf, O. (1999). Le management entre tradition et renouvellement. Montreal: Gaë$\tan$ Morin.

Alaluf, M.; Stroobants, M. (1994). ¿Moviliza la competencia al obrero? Revista Europea de Formación Profesional, 1, pp. 46-55.

Alberdi, I. (1999). La nueva familia española. Madrid: Taurus.

Alexander, J.C. (2000). La reduction critique de Bourdieu. París: Editions du Cerf.

Alexander, J.C.; Smith, Ph. (1998). Sociologie culturelle ou sociologie de la culture? Un programme fort pour donner à la sociologie son second soufflé. Sociologie et sociétés, vol. 30, 1, pp. 107-116.

Alexandre-Bidon, D.; Lett, D. (1997). Les enfants au Moyen âge, V-XV siècles. Poitiers: Hachette.

Alonso, L. E. (2009). Prácticas económicas y economía de las prácticas. Crítica del postmodernismo liberal. Madrid: Los Libros de la Catarata.

Alonso, L. E. (2005). La era del consumo. Madrid: SXXI.

Althusser, L. (1974). La filosofía como arma de la revolución. México: SXXI.

Álvarez González, M. (2005). Los modelos de orientación en España. Presente y futuro. Revista Española de Orientación y Psicopedagogía. Vol. 16, 1, pp. 147-162.

Álvarez-Uría, F. (2000). Capitalismo y subjetividad. La teoría política y social de Michel Foucault. En P. López Álvarez.; J. Muñoz (2000). La impaciencia de la libertad. Michel Foucault y lo político (pp. 85-107). Madrid: Biblioteca Nueva.

Alves, N. (1998). Escola e trabalho: atitudes, projectos e trajectórias. En M. Villaverde Cabral.; J. Machado Pais (orgs.). Jovens Portugueses de Hoje (pp. 53-133). Oeiras: Celta Editora.

Amelang, J.S. (1986). La formación de una clase dirigente: Barcelona 1490-1714. Madrid: Ariel.

Anderson, M. (1988). Aproximación a la historia de la familia occidental, 1500-1914. Madrid: SXXI. 
Andrade, S.; Tolfo, S.; Dellagnelo, E. (2012). Sentidos do trabalho e racionalidades instrumental e substantiva: interfaces entre a administração e a psicología. Revista de Administração Contemporânea, 16 (2), pp. 200-216.

Andrade, M. (1989). A juventude portuguesa: situaçoes, problemas e aspiraçoes. O trabalho, o emprego, a profissâo. Vol III. Lisboa: ICS.

Andrés Orizo, F. (2001). Sistema de valores en la España de los 90. Madrid: CIS.

Andrés Orizo, F. (1999). Jóvenes: Sociedad e instituciones. En J. Elzo (coord.). Jóvenes españoles 99 (pp. 53-120). Madrid: Fundación SM.

Andrés Orizo, F. (1989). Fuerza de personalidad y liderazgo. En P. González Blasco, P. (dir.). Jóvenes españoles 89 (pp. 145-205). Madrid: SM.

Andrés Orizo, F. (1985). El papel de la familia. En F. Orizo (coord.). Juventud española 1984 (pp. 123-189). Madrid: SM.

Andrés Orizo, F. (1983). España, entre la apatía y el cambio social. Madrid: Mapfre.

Arendt, H. (2003a). La crisis en la educación. En H. Arendt: Entre el pasado y el futuro (pp. 269-345). Barcelona: Paidós.

Arendt, H. (2003b). ¿Qué es la autoridad? En H. Arendt: Entre el pasado y el futuro (pp. 145-225). Barcelona. Paidós.

Arendt, H (2003c). La crisis en la cultura. Su significado político y social. En H. Arendt: Entre el pasado y el futuro (pp. 303-345). Barcelona. Paidós.

Arendt, H. (1999). Labor, trabajo, acción. En H. Arendt: De la historia a la acción (pp. 89-107). Barcelona: Paidós.

Arendt, H. (1998). La condición humana. Barcelona. Paidós.

Ariès, Ph. (1987). El niño y la vida familiar en el Antiguo Régimen. Madrid. Taurus.

Ariès, Ph. (1979). L’enfant et la rue, de la ville à l’anti-ville. Urbi, n², pp. III-XIV.

Aristóteles (2004). Política. Madrid. Técnos.

Aristóteles (2000). Retórica. Madrid. Alianza editorial.

Artiaga Leiras, A.; Tovar Martinez, F.J.; Fernández Rodriguez, C.J. (2014a). Mercado de Trabajo y protección social en España. En C.J. Fernández Rodríguez; A. Serrano Pascual: El paradigma de la flexiguridad en las políticas de empleo españolas: un análisis cualitativo (pp. 81-134). Madrid: CIS.

Aritiaga Leiras, A; Martín Martín, M.; Serrano Pascual, A (2014b). Qué significa la orientación: Producción política del desempleado. En CJ. Fernández Rodríguez.; A. Serrano Pascual: El paradigma de la flexiguridad en las políticas de empleo española (pp 411-448). Madrid: CIS.

Augustijn, C. (1990). Erasmo de Rótterdam. Bacelona: Crítica. 
Ayuso Sánchez, L. (2010). Juventud y familia en los comienzos del siglo XXI. En J. González-Anleo.; P. González-Blasco (coords.). Jóvenes españoles 2010 (pp. 115-174). Madrid: SM.

Bacon, F. (1975). Instauratio Magna. Novum Organum. Nueva Atlántida. México: Porrúa.

Bakunin. M. (1979). La instrucción integral. Madrid: SXXI.

Ball, S.J. (2001b). Presentación de Michel Foucault. En S.J. BalL: Foucault y la educación. Disciplinas y saber (pp. 5-12). Madrid: Morata.

Baudelot, CH.; Establet, R. (1975). La escuela capitalista en Francia. Madrid: SXXI.

Bauman, Z. (2010). Mundo de consumo. Barcelona: Paidós.

Bauman, Z. (2007a). Vida de consumo. Madrid: FCE.

Bauman, Z. (2007b). Los retos de la educación en la modernidad líquida. Barcelona: Gedisa.

Bauman, Z. (2006a). Modernidad líquida. Madrid: FCE.

Bauman, Z. (2006b). Vida líquida. Barcelona: Paidós.

Bauman, Z. y Tester, K. (2002). La ambivalencia de la modernidad y otras conversaciones. Barcelona: Paidós.

Bauman, Z. (2000). Trabajo, consumismo y nuevos pobres. Barcelona: Gedisa.

Becchi, E. (1998a). L'antiquité. En: E. Becchi.; D. Julia: Histoire de l’enfant en occident (Vol I) (pp. 43-73). París. Éditions du Seuil.

Becchi, E. (1998b). Le Moyen Âge. En: E. Becchi.; D. Julia: Histoire de leenfant en occi$\operatorname{dent}(\mathrm{Vol}$ I) (pp. 109-141). París. Éditions du Seuil.

Becchi, E. (1998c). Humanisme et Reinessance. En: E. Becchi.; D. Julia: Histoire de l'enfant en occident (Vol I) (pp. 171-210). París. Éditions du Seuil.

Beck, U. (2006). La sociedad del riesgo. Barcelona: Paidós.

Beck, U.; Beck-Gernsheim, E. (2003). La individualización. El individualismo institucionalizado y sus consecuencias sociales y políticas. Barcelona: Paidós.

Beck, U.; Beck-Gernsheim, E. (2001). El normal caos del amor. Barcelona: Paidós.

Béjar, H. (2011). Cultura psicoterapéutica y autoayuda. El código psicológico-positivo. Papers, 96/2, pp. 341-360.

Bell, D. (1977). Las contradicciones culturales del capitalismo. Madrid: Alianza Editorial.

Beltrán Villalba, M. (1984). La subcultura juvenil. En M: Beltrán Villalba et al. (1984). Informe sociológico sobre la juventud española 1960/82 (pp. 175-204). Madrid: Fundación SM.

Bendix, R. (1974). Estado nacional y ciudadanía. Buenos Aires: Amorrortu. 
Benedicto, J. (dir.) (2016). Informe Juventud en España 2016. Madrid: Instituto de la Juventud.

Bernstein, B. (1989). Clases, códigos y control. Madrid: Akal.

Bocock, R. (1995). El consumo. Madrid: Talasa.

Bolívar, A. (2015). El liderazgo pedagógico en una comunidad que aprende. Padres y maestros, 361, pp. 23-27.

Bolívar, A. (2011). Aprender a liderar líderes: Competencias para un liderazgo directivo que promueva el liderazgo docente. Educar, 47 (2), pp. 253-275.

Bolívar, A. (2010). El liderazgo educativo y su papel en la mejora: Una revisión actual de sus posibilidades y limitaciones. Psicoperspectivas, 9 (2), pp. 9-33.

Bolivar, A. (2008). El discurso de las competencias en España: educación básica y educación superior. Revista de Docencia Universitaria, 2, pp. 1-23.

Boltanski, L.; Chiapello, È. (2002). El nuevo espíritu del capitalismo. Madrid: Akal.

Bonner, S.F. (1984). La educación en la Roma Antigua. Barcelona: Herder.

Bourdieu, P. (2010). El sentido social del gusto. Elementos para una sociología de la cultura. Buenos Aires: SXXI.

Bourdieu, P. (2008). Capital cultural, escuela y espacio social. Madrid: SXXI.

Bourdieu, P. (2006). La distinción. Criterios y bases sociales del gusto. Madrid: Taurus.

Bourdieu, P. (2007). El sentido práctico. Madrid: SXXI.

Bourdieu, P.; Passeron, J.C. (2001). La reproducción. Elementos para una teoría del sistema de enseñanza. Madrid: Editorial Popular.

Bourdieu, P.; Passeron, J-C. (1973). Los herederos. Los estudiantes y la cultura. Buenos Aires: Labor.

Bowen, J. (1985). Historia de la educación occidental (Vols. II-III). Barcelona: Herder.

Bowen, J. (1976). Historia de la educación occidental (Vol. I). Barcelona: Herder.

Bowles, S.; Gintis, H. (1998). La instrucción escolar en la américa capitalista. Madrid: SXXI.

Buckingham, D. (2013). La infancia materialista. Crecer en un mundo consumista. Madrid: Morata.

Burckhardt, J. (2004). La cultura del Renacimiento en Italia. Madrid: Akal.

Caballero, M.; Baigorri, A. (2018). Glocalising the theory of generations: The case of Spain. Time \& Society 0(0) pp. 1-25.

Cabet, E. (1985). Viaje por Icaria. En M. Vico Monteoliva.; J. Rubio Carracedo: Escritos sobre educación (vol. I) (pp. 85-156). Málaga: Universidad de Málaga.

Cabral, M., Pais, J.M. (coords.) (1998). Jovens Portugueses de Hoje. Oeiras: Celta. 
Cabrera Montoya, B. (1986). Limitaciones del análisis de Marx sobre la legislación fabril en el Capital. Discusión a propósito de su valoración sobre cláusulas educacionales. Revista de Educación, 281, pp. 213-224.

Campanella, T. (1985). La ciudad del sol. Madrid: FCE.

Campo Urbano, S.; Rodríguez Brioso. M. (2002). La gran transformación de la familia española en la segunda mitad del siglo XX. REIS, 100/02, pp. 103-165.

Campo Urbano, S. (1982). La evolución de la familia española en el siglo XX. Madrid. Alianza Universidad.

Capitan Díaz, A. (1984). Historia del pensamiento pedagógico en Europa (2vols.). Madrid: Dykinson.

Capucha, L. (1998). Pobreza, exclusão social e marginalidades. En J.L. Viegas.; A. Firmino da Costa (orgs.). Portugal, que Modernidade? (pp. 209-242). Oeiras: Celta Editora.

Carmo, R.; Cantante, F.; Almaida, N. (2014). Time projections: Youth and precarious employment. Time \& Society, Vol. 23 (3), pp. 337-357.

Castiglione, B. (1994). El cortesano. Madrid: Cátedra.

Castilla Vallejo, J.L. (1999a). Análisis del poder en Michel Foucault. Consecuencias para la sociología de la educación. Santa Cruz de Tenerife: Universidad de La Laguna.

Castilla Vallejo, J.L. (1999b). ¿Qué hay de Foucault en los análisis foucaultianos de la sociología de la educación? Témpora. Segunda época. Vol. 2, pp. 275-308.

Chaney, D. (2003). Estilos de vida. Madrid: Talasa.

Cicerón (1959). Los oficios. Madrid: Espasa Calpe.

CIS (1997). Juventud y entorno familiar. Madrid: INJUVE.

CIS (1994). Encuesta sobre vida de familia. Estudio 2087.

Coleman, J.S. (1961). The adolescent society: the social life of the teenager and its impact on education. Oxford: Free Press of Glencoe.

Comas Arnau, D (coord.). (2003). Jóvenes y estilos de vida. Madrid: Injuve

Comas Arnau, D. (2000). Agobio y normalidad. Una mirada crítica sobre el sector “ocio juvenil" en la España actual. Estudios de Juventud, 50, pp. 9-22.

Comenius, J.A. (1976). Didáctica Magna. México: Porrúa.

Comisión de las Comunidades Europeas (1993). Libro Blanco. Crecimiento competitividad y empleo. Retos y pistas para entrar en el siglo XXI. Bruselas: Oficina de publicaciones Oficiales de las Comunidades Europeas.

Conde, F. (1999). Los hijos de la desregulación. Jóvenes, usos y abusos en los consumos de drogas. Madrid: CREFAT. 
Condorcet (2000). Cinco memorias sobre la instrucción pública y otros escritos. Madrid: Morata.

Coombs, Ph. (1985). La crisis mundial en la educación. Perspectivas actuales. Madrid: Santillana.

Cook, D. (2004). The commodification of Childhood. The Children's clothing industry and the rise of the child consumer. Duke: Univesity Press.

Crozier, M. (1995). L’entreprise à l'écoute. París: Éditions du Seuil.

Crouzet-Pavan, É. (1996). Una flor del mal: los jóvenes en la Italia medieval (siglos XIII al XV). En G. Levi.; J-C. Schmitt (dir.). Historia de los jóvenes (Vol I). (pp. 217-267). Madrid: Taurus.

Cuzzocrea, V. (2018). Moratorium or waithood? Forms of time-taking and the changing shape of youth. Time \& Society, 0(0), pp. 1-20.

Deleuze, G. (1999). Conversaciones. Valencia: Pre-Textos.

Della Casa, G. (2003). Galateo. Madrid: Cátedra.

De Lora, C. (1965). Juventud española actual. Madrid: Ediciones y Publicaciones españolas.

De Miguel, A. (coord.) (2000). Dos generaciones de jóvenes 1960-1998. Madrid: Ministerio de trabajo y Asuntos Sociales.

De Miguel, A. (1992). La sociedad española 1992-1993. Madrid: Alianza Editorial.

Del Valle, A. (1994). Vida cotidiana y relaciones personales. En J. Elzo (dir.). (1994). Jóvenes españoles 94 (pp. 89-139). Madrid: SM.

Demoustier, A.; Julia, D. (1997). Prefacio a la edición de la Ratio Studiorum. París: Belin.

Dewey, J. (1995). Democracia y educación. Madrid: Morata.

Dewey, J. (1915). La escuela y la sociedad. Madrid: Librería Francisco Beltrán.

Dewey, J. (1908). Mi credo pedagógico. Santiago de Chile: Revista de la Asociación de Educación Nacional de Santiago de Chile.

Díaz Allué, M.; Carballo Santaolalla, R.; Fernández Díaz, M.J.; García Nieto, N. (1997). Orientación en educación secundaria. Situación actual y prospectiva. Revista de Investigación Educativa, Vol. 15, n 2, pp 9-84.

Dietrich, Th. (1976). Pedagogía socialista. Salamanca: Sígueme.

Dommaget, M. (1972). Los grandes socialistas y la educación. De Platón a Lenin. Madrid: Fragua.

Dubet, F. (2006). El declive de la institución. Profesiones, sujetos e individuos ante la reforma del Estado. Barcelona: Gedisa. 
Duque, E. (2007). Os jovens e a religiâo na sociedade actual. Comportamentos, crenças, atitudes e valores no distrito de Braga. Braga: Instituto Português da Juventude.

Durán Vázquez, J.F.; Duque, E. (2018). Trayectorias y actitudes generacionales. Temporalidades y actitudes ante la educación, el trabajo y el consumo de tres generaciones de jóvenes españoles y portugueses. Sociologia, problemas e práticas, 87, pp. 9-28.

Durán Vázquez, J.F. (2015). Los discursos críticos de la educación, el programa educativo moderno y el nuevo espíritu de la educación. Intersticios: Revista Sociológica de Pensamiento Crítico, Vol. 9 (2), pp. 283-301.

Durán Vázquez, J.F. (2012). La educación y la esfera pública: Del proyecto colectivo a las incertidumbres del individualismo mercantilista y democrático. Nómadas, Vol I, 35, pp. 41-66.

Durán Vázquez, J.F. (2011). La metamorfosis de la ética del trabajo. Constitución, crisis y reconfiguración de la ética del trabajo en la modernidad tardía. Santiago de Compostela: Andavira.

Durán Vázquez, J.F. (2008). La educación moral durkheimiana y la crisis de la esfera educativa en el mundo tardo-moderno. Nómadas, 17, pp. 207-220.

Durán Vázquez, J.F. (2006). La construcción social del concepto moderno de trabajo. Nómadas, 13/1, pp. 219-236.

Durkheim, É (2002). La educación moral. Madrid: Morata.

Durkheim, É (2000). Sociología y filosofía. Buenos Aires: Miño y Dávila.

Durkheim, É. (1995a). La división del trabajo social. Madrid: Akal.

Durkheim, É. (1995b). El suicidio. Madrid: Akal.

Durkheim, É. (1992). Historia de la educación y de las doctrinas pedagógicas. La evolución pedagógica en Francia. Madrid: La Piqueta.

Durkheim, É. (1985). Las reglas del método sociológico. Madrid: Akal.

Ehrenberg, A. (1998). La fatigue dêtre soi. París. Edile Jacob.

Elias, N. (1993a). El proceso de civilización. Madrid: FCE.

Elias, N. (1993b). La sociedad cortesana. Madrid: FCE.

Elzo, J.; Castiñeira, Á. (dirs.). (2012). Valores blandos en tiempos duros: la sociedad catalana en la Encuesta Europea de Valores. Barcelona: Proteus.

Elzo, J. (2006). Valores e identidades de los jóvenes. En P. González Blasco. (dir.). Jóvenes españoles 2005 (pp. 3-110). Madrid: SM.

Elzo, J. (2004). Tipología y socialización de las familias españolas. Arbor CLXXVIII, 702, pp. 205-229. 
Elzo, J. (1999). Reflexiones finales. En J. Elzo (coord.). Jóvenes españoles 99 (pp. 401 433). Madrid: Fundación SM.

Enkvist, I. (2000). La educación en peligro. La pedagogía progresista y el declive de nuestro sistema educativo. Madrid: Unisón Producciones.

Erasmo de Rotterdam (2005). Coloquios familiares. Barcelona: Anthropos.

Erasmo de Rotterdam (1985). De la urbanidad en las maneras de los niños. Madrid: Artegraf.

Erasmo de Rotterdam (1964). De cómo los niños han de ser precozmente iniciados en la piedad y en las buenas letras. En Erasmo: Obras escogidas (pp. 927-962). Madrid: Aguilar.

EVS (1990) www.europeanvaluesstudy.eu/page/survey-1990.html. Acceso11/01/2018

EVS (2008) www.europeanvaluesstudy.eu/page/survey-2008.html. Acceso 11/11/2018.

Ewen, S. (1983). Consciences sous influence. Publicité et genèse de la societé de consommation. París: Aubier.

Featherstone, M. (2000). Cultura de consumo y postmodernismo. Buenos Aires: Amorrortu.

Feixa, C. (2014). De la Generación@ a la \#Generación. La juventud en la era digital. Barcelona: Ned Ediciones.

Fernández Enguita M. (2001). Educar en tiempos inciertos. Madrid: Morata.

Fernández Enguita, M. (1990). La cara oculta de la escuela. Educación y trabajo en el capitalismo. Madrid: SXXI.

Fernández Rodriguez, C. (2007). El discurso del management: tiempo y narración. Madrid: CIS.

Ferrer i Guardia, F. (1978). La escuela moderna. Póstuma explicación y alcance de la enseñanza racionalista. Barcelona: Tusquets.

Ferreira, P.A. (1993). Valores dos jovens portugueses nos anos 80. Lisboa: Instituto de Ciências Sociais/Instituto da Juventude.

Ferry, L.; Rénaut, A. (1985). La pensé 68. Essai sur l’anti-humanisme contemporain. París: Gallimard.

Figueiredo, A., Silva, C.; Ferreira, V. (1999). Jovens em Portugal: Análise Longitudinal de Fontes Estatísticas (1960-1997). Estudos sobre Juventude, n³. Oeiras: Obervatório Permanente da Juventude Portuguesa. Celta Editora. Secretaria de Estado da Juventude.

Flandrin, J.L. (1979). Orígenes de la familia moderna. Barcelona: Crítica.

Foucault, M. (2009). Las palabras y las cosas. Madrid: SXXI.

Foucault, M. (1999). Vigilar y castigar. Barcelona: Círculo de Lectores. 
Foucault, M. (1986). Por qué hay que estudiar el poder: la cuestión del sujeto. En VV.AA: Materiales de sociología critica (pp. 25-36). Madrid: La Piqueta.

Fourier, Ch. (1989). El nuevo mundo industrial y societario. México: FCE.

Frank, Th. (2011). La conquista de lo cool. El negocio de la cultura y de la contracultura y el nacimiento del consumismo moderno. Madrid: Alpha Decay.

Funes, $M^{\mathrm{a}}$ J. (2008). Cultura, política y sociedad. En Injuve: Informe Juventud en España 2008. (Vol. 4). Madrid: Injuve.

Gabbard, D.; Stuchul, D. (2001). “Ivan Illich”. En J. Palmer (ed.) (2001). Fifty Modern Thinkers on Education (pp. 181-188). New York: Routledge.

Gaitán, L.; Libel, M. (2011). Ciudadanía y derechos de participación de los niños. Madrid: Síntesis.

Gaitán, L. (1999). El espacio social de la infancia. Los niños en el Estado de Bienestar. Madrid: Consejería de Sanidad y Servicios Sociales de la Comunidad de Madrid.

García Ferrando, M. (1984a). Situación laboral de la juventud española. En M. Beltrán Villalba et al. (1984). Informe sociológico sobre la juventud española 1960/82 (pp. 23-53). Madrid: Fundación SM.

García Ferrando, M. (1984b). La situación de estudios de los jóvenes españoles. En M. Beltrán Villalba et al: Informe sociológico sobre la juventud española 1960/82 (pp. 55-76). Madrid: Fundación SM.

Garin, E. (1998). L'image de l’enfant dans la pédagogie du XV siécle. En Becchi, E y Julia, D: Histoire de l’enfant en occident (Vol I). (pp. 247-293). París: Éditions du Seuil.

Garin, E. (1987). La Educación en Europa 1400-1600. Barcelona: Grijalbo.

Gauchet, M. (2002). La démocratie contre elle-même. París: Gallimard.

Génelot, D. (1992). Manager dans la complexité. París: Insep éditions.

Genovesi, A. (1785). Lecciones de comercio, o bien de economía civil (3 Vols). Madrid: Edición de la viuda de Ibarra, hijos y compañía.

Gergen, K. (1997). El yo saturado. Dilemas de la identidad en el mundo contemporáneo. Barcelona: Paidós.

Gerver, R. (2012). Crear hoy la escuela del mañana. La educación y el futuro de nuestros hijos. Madrid: SM.

Giddens, A. (2007). Sociología. Madrid: Alianza Editorial.

Giddens, A. (2006). La transformación de la intimidad. Sexualidad, amor y erotismo en las sociedades modernas. Madrid: Cátedra.

Giddens, A. (2005). Un mundo desbocado. Los efectos de la globalización en nuestras vidas. Madrid: Taurus. 
Gimeno Sacristán, J. (2008). Diez tesis sobre la aparente utilidad de las competencias en educación. En J. Gimeno Sacristán: Educar por competencias ¿Qué hay de nuevo? (pp. 15-58). Madrid: Morata.

Giroux, H. (1985a). Teorías de la reproducción y la resistencia en la nueva sociología de la educación: un análisis crítico. Cuadernos políticos. México: Era, pp. 36-65.

Giroux, H. (1985b). La educación pública y el discurso de la crisis, el poder y el futuro. Revista de Educación, 283, pp. 5-24.

Gobernado Arribas, R. (1988). La construcción del sistema educativo meritocrático. Revista española de pedagogía, 180, pp. 306-317.

González Anleo, J. (1999). Familias y escuela en la socialización de los jóvenes españoles. En J. Elzo (coord.). Jóvenes españoles 99 (pp. 121-182). Madrid: SM.

Gonzalez-Anleo, J. (1984). Los jóvenes españoles y la familia. En M. Beltrán Villalba et al: Informe sociológico sobre la juventud española 1960/82 (pp. 77-116). Madrid: Fundación SM.

Gonzalez-Anleo, J. (1981). Los hijos: cómo ven a los padres. Madrid: Jardiel Poncela.

González-Anleo Sánchez, J.M. (2014). Consumidores consumidos. Juventud y cultura consumista. Madrid: Khaf.

González-Anleo Sánchez, J.M. (2010). Los valores de los jóvenes y su integración socio-política. En J. González-Anleo.; P. González Blasco. (coords.). Jóvenes españoles 2010 (pp. 9-114). Madrid: Fundación SM.

González-Anleo Sánchez, J. M. (2006). Relaciones e integración. En P. González Blasco (dir.). Jóvenes Españoles 2005 (pp. 111-184). Madrid: Fundación SM.

González-Blasco, P. (2005). Familia y jóvenes. En P. González-Blasco (coord.) Jóvenes españoles 2005 (pp. 185-239). Madrid: Fundación S.M.

González Blasco, P. (1999). Relaciones sociales y espacios vivenciales. En J. Elzo (coord.). Jóvenes españoles 99 (pp. 183-262). Madrid: Fundación SM.

González Blasco, P. (1994). Los jóvenes y su identidad. En J. Elzo (dir.). Jóvenes españoles 94 (pp. 25-88). Madrid: SM.

González Monteagudo, J. (2007). John Dewey y la pedagogía progresista. En Trilla, J. (coord.): El legado pedagógico del siglo XX para la escuela del siglo XXI (pp. 1539). Barcelona: Graó.

Goodich, M. (1998). Une enfant sainte, une sainte des enfants: l'enfance de sainte Élisabeth de Hongrie. En E. Becchi.; D. Julia: Histoire de l'enfant en occident (Vol I). París: Éditions du Seuil.

Gorz, A. (2000). Miserias del presente, riqueza de lo posible. Buenos Aires: Paidós. 
Grañeras Pastrana, M.; Parras Laguna, A. (coords.) (2009). Orientación educativa: fundamentos teóricos, modelos institucionales y nuevas perspectivas. Madrid: CIDE.

Grignon, C.; Passeron, J-C. (1989). Lo culto y lo popular. Buenos Aires: Nueva Visión.

Guerreiro, M.; Abrantes, P. (2003). Transiçoes incertas. Os jovens perante o trabalho e a familia. Lisboa: CIES.

Gutiérrez Zuluaga, I. (1975). Hombre, Trabajo, educación en Karl Marx. Valencia: Universidad de Valencia.

Habermas, J. (1999). Problemas de legitimación en el capitalismo tardío. Madrid: Cátedra.

Habermas, J. (1993). El discurso filosófico de la modernidad. Madrid: Taurus.

Habermas, J. (1982). Historia y crítica de la opinión pública. Barcelona: Gustavo Gili.

Harris, Ch. (1986). Familia y sociedad industrial. Barcelona: Península.

Hattam, R.; Smyth, J. (2014). Thinking Past Educational Disadvantage, and Theories of Reproduction. Sociology, 14, pp. 1-17.

Heath, J.; Potter, A. (2005). Rebelarse vende. El negocio de la contracultura. Madrid: Taurus.

Hobson, P. (2001). “A. S Neill”. En J.A. Palmer (ed.): Fifty Modern Thinkers on Education (pp. 1-6). New York: Routledge.

Homero (2006). Iliada. Barcelona: Gredos.

Horkheimer, M.; Adorno, Th.W. (1999). Dialéctica del Iluminismo. Barcelona: Círculo de Lectores.

Hoskin, K. (2001). Foucault a examen. El criptoteórico de la educación desenmascarado. En S.J Ball: Foucault y la educación. Disciplinas y saber (pp. 33-57). Madrid: Morata.

Huizinga, J. (1987). Erasmo (2 Vols.). Barcelona: Salvat.

ICS (1998). A Juventude Portuguesa: Situações, Problemas, Aspirações. Lisboa: ICS.

ICS (1987). A Juventude Portuguesa. Situações, Problemas e Aspirações. Lisboa: ICS.

Igelmo Zaldivar, J. (2012). Las teorías de la desescolarización; cuarenta años de perspectiva histórica. Social and Education History, 1(1), pp. 2857.

Illich, I. (1973). La sociedad desescolarizada. Barcelona: Barral.

Illouz, E. (2012). Por qué duele el amor. Una explicación sociológica. Madrid: Katz.

Illouz, E. (2010). La salvación del alma moderna. Terapia, emociones y la cultura de la autoayuda. Madrid: Katz.

INE - Instituto Nacional de Estatística (1960). X Recenseamento Geral da População, 1960. Tomo III, Vol. 2º Lisboa: INE. 
INE - Instituto Nacional de Estatística (2001). Censos 2001. Resultados Definitivos. XIV Recenseamento Geral da População. Lisboa: INE.

Inglehart, R. (1990). Cambio cultural en las sociedades Industriales avanzadas. Madrid: CIS.

Injuve (2014) http://www.injuve.es/observatorio/demografía-e-información-general informe-de-la-juventud-en-españa-2014. Acceso 29-03-2016.

Injuve (1975). III encuesta Nacional a la Juventud. Madrid: Injuve.

Jacobson, L. (2004). Raising Consumers: Children and the American Mass Market in the Early Twentieh Century. Nueva York: Columbia University Press.

Jaeger, W. (1996). Paideia. Madrid: FCE.

Jencks, Ch. (1973). Inequality in Retrospect. Harvard Educational Review, 43, pp. 138-164.

Jencks, Ch. et al (1972). Inequality: A Reassessment of the Effect of Family and Schooling in America. Nueva York: Basic Books.

Julia, D. (1998). Lenfance aux débuts de l'époque moderne. En E. Bechi.; D. Julia: Histoire de l'enfant en occident (Vol I) (pp. 303-360). París. Éditions du Seuil.

Julia, D. (1989a). L'institution du citoyen. L'instruction publique et éducation nationale dans les projets de la péridode révolutionnaire (1789-1795). En M.F. Lévy (dir.). Lenfant, la famille et la révolution française. París: Institut de l'enfance et de la famille.

Julia, D. (1989b). Léducation révolutionnaire: fille de sparte ou heritière des lumières. En M.F. Lévy (dir.). Lenfant, la famille et la révolution française. París: Institut de l'enfance et de la famille.

Julia, D (1981). Les trois couleurs du tableau noir. La Révolution. Paris: Bélin.

Jurado Guerrero, T. ; Echaves, A. (2016). La situación social de los jóvenes. Trayectorias educativas y relación con el mundo del trabajo. En J. Benedicto (dir.). (2016). Informe Juventud en España 2016 (pp. 57-188). Madrid: Instituto de la Juventud.

Kojève, A. (2005). La noción de autoridad. Buenos Aires: Nueva Visión.

Klaspich-Zuber, Ch. (1998). L'enfant, la mémoire et la mort dans l'italie des XIV et XV Siècles. En Becchi, E y Julia, D: Histoire de l'enfant en occident (Vol I) (pp. 214246). París. Éditions du Seuil.

Laespada, T.; Salazar, L. (1999). Las actividades no formalizadas de los jóvenes. En J. Elzo (coord.). Jóvenes españoles 99 (pp. 355-400). Madrid: Fundación SM.

Landier, H. (1992). Hacia la empresa inteligente. Bilbao: Deusto.

Lash, C. (1999). La cultura del narcisismo. Barcelona: Andrés Bello. 
Lash, C (1984). Refugio en un mundo despiadado. La familia: ¿santuario o institución asediada? Barcelona: Gedisa.

Laval, Ch. (2004). La escuela no es una empresa. El ataque neoliberal a la enseñanza pública. Barcelona: Paidós.

Leccardi, C.; Feixa, C. (2011). El concepto de generación en las teorías sobre la juventud, 34, pp. 11-32.

Le Goff, J-P. (2002). La démocratie post-totalitaire. París. La Découverte.

Le Goff, J-P. (1999). La barbarie douce. La modernisation aveugle des enterprises et de lécole. París: La Découverte.

Le Roy Ladurie, E. (1975). Montaillou, village occitan de 1294 à 1234. París: Gallimard. Lett, D (1997). L’enfant des miracles. París: Aubier.

Levi, G.; Schmitt, J.C. (dirs). (1996). Historia de los jóvenes (Vo I) Madrid: Taurus.

Lima, L.; Pacheco, J.; Esteves, M.; Canário, R. (2006). A Educação em Portugal (19862006). Alguns contributos de investigação. Sociedade Portuguesa de Ciências da Educação.

Lima, L.; Janela Afonso, A. (2002). Reformas da educação pública. Democratização, Modernização, neoliberalismo. Porto: Ediçôes Afrontamento.

Lipovestky, G. (2007). La felicidad paradójica. Ensayo sobre la sociedad del hiperconsumo. Madrid. Anagrama.

Lipovetsky, G. (2003). Metamorfosis de la cultura liberal. Ética, medios de comunicación, empresa. Barcelona: Anagrama.

Lipovetsky, G. (1994). El crepúsculo del deber. La ética indolora de los nuevos tiempos democráticos. Barcelona: Anagrama.

Lipovestky, G. (1987). La era del vacío. Ensayos sobre el individualismo contemporáneo. Barcelona: Anagrama.

Locke, J. (2006). Segundo Tratado sobre el Gobierno Civil. Madrid: Alianza Editorial.

Locke, J. (1982). Pensamientos acerca de la educación. Madrid: Humanitas.

López Ruíz, J. (2006). Ocio y tiempo libre. En P. González Blasco (dir.). Jóvenes españoles 2005 (pp. 345-402). Madrid: SM.

Lukes, S. (1984). Émile Durkheim. Su vida y su obra. Madrid: SXXI.

Lutero, M (1961a). Aux magistrats de toutes les villes allemandes pour les inviter à ouvrir et à entretenir des écoles chrétiennes. En M. Lutero: Euvres (Tomo IV) (pp. 95-118). Genève: Labor et Fides.

Lutero, M (1961b). Une prédication sur le devoir d'envoyer les enfants à lécole. En M. Lutero: Euvres (Tomo IV) (pp. 159-197). Genève: Labor et Fides.

Luzuriaga, L. (1994). Historia de la educación y de la pedagogía. Buenos Aires: Losada. 
Manacorda, M. (1987). Historia de la Educación (Vol. II). México: SXXI.

Manacorda, M. (1972). Los grandes socialistas y la educación. De Platón a Lenin. Madrid: Fragua.

Manacorda, M. (1969). Marx y la pedagogía moderna. Barcelona: Oikos-Tau.

Mannheim, K. (1990). Le problème des génerations. París: Natham.

Margulis, M., Urresti, M. (1996). La juventud es más que una palabra. En M. Margulis: La juventud es más que una palabra: ensayos sobre cultura y juventud (pp. 1330). Buenos Aires: Biblos.

Marrou, H.I. (1985). Historia de la educación en la Antigüedad. Madrid: Akal.

Marshall, T.H.; Bottomore, T. (1998). Ciudadanía y clase social. Madrid: Alianza Editorial.

Martín Criado, E. (2010). La escuela sin funciones. Crítica de la sociología de la educación crítica. Barcelona: Bellaterra.

Martín Criado, E. (2003). Una crítica de la sociología de la educación crítica. Anduli, 2, pp. 9-27.

Martín Criado, E. (1998). Producir la juventud. Crítica de la sociología de la juventud. Madrid: Itsmo.

Martín Escudero, M. (1994). Estudio y trabajo. En M. Martín Serrano. (dir.). Historia de los cambios de mentalidades de los jóvenes entre 1960-1990 (pp. 129-169). Madrid: Injuve.

Martín Serrano, M.; Velarde Hermida, O. (coords). (2001). Informe Juventud en España 2000. Madrid: Injuve.

Martín Serrano, M. (1994). Tres visiones del mundo, para cuatro generaciones de jóvenes. En M. Martín Serrano. (dir.). Historia de los cambios de mentalidades de los jóvenes entre 1960-1990 (pp. 17-54). Madrid: Injuve.

Marx, K. (2001). Manuscritos de economía y filosofía. Madrid: Alianza Editorial.

Marx, K. (1999). El Capital. Madrid: FCE.

Marx, K. (1984). La ideología alemana. Universidad de Valencia.

Marx, K (1981a). Manifiesto del partido comunista. En: K. Marx y F. Engels: Obras escogidas. Moscú: Progreso.

Marx, K (1981b). Instrucciones sobre diversos problemas a los delegados del Consejo Central Provisional. En K. Marx y F. Engels: Obras escogidas. Moscú: Progreso.

Marx, K.; Engels, F. (1978). Textos sobre educación y enseñanza. Madrid: Alberto Corazón.

Marx, K. (1971). Critica al Programa de Gotha. Guadalajara: Intergraf. 
Mead, M. (1971). Cultura y compromiso. Estudio sobre la ruptura generacional. Buenos Aires: Granica.

Mead, M. (1962). Educación y cultura. Buenos Aires: Paidós.

Megías Valenzuela, E. (coord.) (2003). Hijos y padres: comunicación y conflictos. Madrid: FAD.

Meil Landwerlin, G. (2006). Padres e hijos en la España actual. Barcelona: Fundación La Caixa.

Meil Landwerlin, G. (1999). La postmodernización de la familia en España. Madrid: Acento.

Miguelez, F.; Prieto, C. (1999) (coords.). Las relaciones de empleo en España. Madrid: SXXI.

Monnier, R. (1990). Lécole du citoyen. En M.F. Lévy (dir.). L'enfant, la famille et la révolution française. París: Institut de l'enfance et de la famille.

Montesquieu (1972). Del espíritu de las leyes. Madrid: Tecnos.

Moreno, A. (2002). El mito de la ruptura generacional de los jóvenes españoles. Revista de estudios de la Juventud, 58, pp. 1-16.

Morgenstern de Finkel, S. (1987). Crisis de acumulación y respuesta educativa de la "nueva derecha”. Revista de Educación, 283, pp. 63-78.

Moss Kanter, R. (1999). Las nuevas fronteras del management. Barcelona: Paidós.

Moya, C. (1984). Señas de Leviatán. Estado nacional y sociedad industrial: España 1936-1980. Madrid: Alianza Editorial.

Muñoz Carrión, A. (2010). El tiempo subjetivo de los jóvenes: hacia un régimen de la inmediatez. En J.C. Mingote.; M. Requena. (eds.). El malestar de los jóvenes: contextos, raíces y experiencias (pp. 67-98). Madrid: Ediciones Díaz de Santos.

Muñoz Carrión, A. (1994). Aspiraciones y objetivos existenciales. En M. Serrano (dir.) (1994). Historia de los cambios de mentalidades de los jóvenes entre 1960-1990 (pp. 207-220). Madrid: Injuve.

Murillo Torrecilla, F.J. (2006). Una Dirección Escolar para el Cambio: del Liderazgo Transformacional al Liderazgo Distribuido. REICE, Vol. 4, 4, pp. 11-24.

Neill, A.S. (1997). Summerhill. Un punto de vista radical sobre la educación de los niños. Madrid: FCE.

Neraudau, J-P. (1998) L'enfant dans la culture romaine. En: E. Becchi.; D. Julia: Histoire de l'enfant en occident (Vol I). París: Editions du Seuil.

Neraudau, J-P. (1984). Être enfant à Rome. París: Les Belles Lettres.

Neraudeau, J-P. (1979). La Jeunesse dans la litterature et les institutions. París: Les Belles Lettres. 
Nilsen, A. (1998). Jovens para sempre? Uma perspectiva da individualização centrada nos trajectos de vida. Sociologia, Problemas e Práticas, 27, pp. 59-78.

Nubiola, J.; Sierra, B. (2001). La recepción de Dewey en España y Latinoamérica. Utopía y Praxis Latinoamericana, 13, pp. 107-119.

Nunes, A.S. (1968). População Universitária portuguesa: análise preliminar. Análise Social, 22-24, pp. 295-385.

OCDE (2009). TALIS (Estudio internacional sobre la enseñanza y el aprendizaje. Informe español 2009). Madrid: Ministerio de Educación, Cultura y Deporte.

OCDE (2000). Societé du savoir et gestions des connaissances, enseignement et compétences. París: OCDE.

OCDE (1998). Lécole à la page. Formation continue et perfectionnement professionnel des enseignantes. París: OCDE.

OCDE (1992). Écoles et entreprises: Un nouveau partenariat. París: OCDE.

OCDE (1991). Escuelas y calidad de la enseñanza. Madrid: MEC.

Orgogozo, I. (1991). Les paradoxes du management. París : Les éditions d’organisation.

Ortega y Gasset, J. (1961). El tema de nuestro tiempo. Madrid: Revista de Occidente.

Ortega, F. (eds.) (1993). Sociología de la educación. Barcelona: Barcanova.

Owen, R. (1985). El libro del nuevo mundo moral. En M. Vico Monteoliva.; J. Rubio Carracedo: Escritos sobre educación (vol. I) (pp. 171-280). Málaga: Universidad de Málaga.

Ozouf, M. (1992). La republique des instituteurs. París: Gallimard.

Ozouf, M. (1984). Lécole de la France. Essais sur la Révolution, l’utopie et l'enseignement. París: Gallimard.

Pais, J.M. (2009). A Juventude como fase de vida: dos ritos de passagem aos ritos de impasse. Saúde e Sociedade. Vol. 18, (3), 371-381.

Pais, J.M. (2005). Ganchos, tachos e biscates: jovens, trabalho e futuro. Âmbar: Porto.

Pais, J.M. (2003a). Culturas juvenis. Lisboa: Imprensa Nacional-Casa da Moeda.

Pais, J.M. (2003b). The Multiple Faces of the Future in the Labyrinth of Life. Journal of Youth Studies, Vol. 6, 2, pp. 115-126.

Pais, J.M. (1999). Geraçôes e valores na sociedade portuguesa contemporánea. Lisboa: SEJ/ICS.

Pais, J.M. (coord.). (1998). Gerações e Valores na Sociedade Portuguesa Contemporânea. Lisboa: ICS.

Pais. J.M. (1996). Pesquisa bibliográfica sobre jovens portugueses (1985-1995). Sociologia, Problemas e Praticas, 21, pp. 225-245. 
Pais, J.M. (1989). Juventude Portuguesa. Situações, Problemas, Aspirações - A Convivialidade e a Relação com os Outros. Lisboa: Instituto da Juventude e Instituto de Ciências Sociais da Universidade de Lisboa.

Pallarés Gómez, J.; Feixa Pampols, C. (2015). Espacios e itinerarios para el ocio juvenil nocturno. Revista de estudios de Juventud, 100, pp. 23-41.

Pappámikail, L. (2011). Juventude entre a fase da vida e tempo de viver. En A. Nunes de Almeida (coord.). Historia da vida privada (Vol 4) (pp. 208-241). Lisboa: Temas \& Debates.

Pappámikail, L. (2005). Sentidos de la edad adulta: juventud y cambio social en el Portugal contemporáneo. Revista de Estudios de Juventud, 71, pp. 43-55.

Pardo, J.L. (2000). Máquinas y componendas. La filosofía política de Deleuze y Foucault. En P. López Álvarez.; J. Muñoz. (2000). La impaciencia de la libertad. Michel Foucault y lo político (pp. 23-84). Madrid: Biblioteca Nueva.

Pastor de Togneri, R. (1986). Papel e imagen de la "Juventus" en la España medieval. Revista de Educación, 281, pp. 87-97.

Pastoureau, M. (1996). Los emblemas de la juventud. Atributos y formas de representación de los jóvenes en la imagen medieval. En G. Levi.; J-C. Schmitt (dirs.). Historia de los jóvenes. (Vol I). (pp. 281-299). Madrid: Taurus.

Pérez-Díaz, V.; Rodriguez, J.C.; Sánchez Ferrer, L. (2001). La familia española ante la educación de sus hijos. Barcelona: La Caixa.

Pérez Gómez, Á. (2008) ¿Competencias o pensamiento práctico? La construcción de los significados de representación y de acción. En J. Gimeno Sacristán: Educar por competencias ¿qué hay de nuevo? (pp. 59-102). Madrid: Morata.

Pestalozzi, J.E. (1965). Cómo Gertrudis enseña a sus hijos. México: Fernández Editores.

Peters, T. (2002). La formación en la empresa del III milenio. Madrid: Nowtilus.

Piore, M.; Sabel, Ch. (1990). La segunda ruptura industrial. Madrid: Alianza Editorial.

Platón (2003). La República. Madrid: Alianza Editorial.

Plutarco (1992). La educación de los hijos. Obras morales y de costumbres (Vol I) Madrid: Gredos.

Pollard, S. (1987). La génesis de la dirección de empresa moderna. Estudio sobre la Revolución Industrial en Gran Bretaña. Madrid: Ministerio de Trabajo y SS.

Pont, B., Nusche, D.; Moorman, H. (2008) (Eds.). Improving school leadership. Vol 2: case studies on system leadership. Paris: OCDE.

Prats, J.; Reventós, F. (dir.) (2005). Los sistemas educativos europeos ¿Crisis o transformación? Barcelona: Fundación La Caixa.

Prost, A. (1970). Histoire de l'ensegnement en France, 1800-1967. París: Armand Colin. 
Puig Rovira, J.M. (2009). Alexander S. Neill y las pedagogías antiautoritarias. En J. Trilla Bernet: El legado pedagógico del siglo XX para la escuela del siglo XXI (pp. 151-176). Barcelona: Graó.

Rabelais, F. (1971). Gargantúa y Pantagruel. Barcelona: Bruguera.

Ramirez, O.; Boli, J. (2001). La construcción de la escolarización de masas: sus orígenes europeos e institucionalización mundial. En: M. Fernández Enguita, M (coord.). Sociología de la educación (pp. 297-314). Madrid: Alianza Editorial.

Ramiro, J. (2015). De los derechos para la infancia a la ciudadanía de los niños. Estrategias de orden y control social (siglos XVIII al XXI). e-SLegal History Review, 19, pp. 1-42.

Ramos Torre, M.; Benedicto, J. (2016). El bienestar subjetivo de los jóvenes. En J. Benedicto (dir.). Informe Juventud en España 2016 (pp.275-326). Madrid: Instituto de la Juventud.

Ramos Torre, R. (2008). Los tiempos vividos. En C. Prieto.; R. Ramos: Nuevos tiempos de trabajo. Entre la flexibilidad competitiva y las relaciones de género (pp. 107178). Madrid: CIS.

Ramos Torre, R. (1982). Introducción a Durkheim: El socialismo. Madrid: Editora Nacional.

Ranciére, J. (1984). L’empire du sociologue. París: La Découverte.

Raynaud, Ph. (1983). L'esprit démocratique et la crise de l’enseignement. Le Débat, 26, pp. 113-122.

Rénaut, A. (2002). La libération des enfants. París: Hachette.

Resende, J.M. (2010). ¿A sociedade contra a escola? A socializaçao política escolar nun contexto de incerteza. Lisboa: Instituto Piaget.

Revault D’allonnes, M. (2008). El poder de los comienzos. Ensayo sobre la autoridad. Buenos Aires: Amorrortu.

Riché, P. (1995). Éducation et culture dans l'occident barbare VI-VIII siècle. París: Éditions du Seuil.

Riché, P.; Alexander-Bidón, D. (1994). L’enfance au Moyen Âge. París: Éditions du Séuil.

Rocha, E. (1977). Portugal, anos 60: crescimento económico acelerado e papel das relações com as colónias. Análise Social, XIII (51), pp. 593-617.

Robertson, P. (1994). El hogar como nido: La infancia de la clase media en la Europa del siglo XIX (pp. 444-471). En Lloyd de Mause (dir.). Historia de la infancia. Madrid, Alianza Editorial.

Rodriguez, J. (1988). « Crisis » del Estado del Bienestar y política educativa. Arbor, 514, pp. 99-120. 
Rodriguez Pascual, I. (2007). Para una sociología de la infancia: aspectos teóricos y metodológicos. Madrid: CIS.

Ropé, F.; Tanguy L. (1994). Savoirs et compétences. De l'usage de ces notions dans l'école et l'entreprise. París: L'Harmattan.

Rosa, H. (2016). Alienación y aceleración. Hacia una teoría crítica de la temporalidad en la modernidad tardía. Madrid: Katz.

Rousseau, J.J. (2003a). Sobre las ciencias y las artes. Madrid: Alianza Editorial.

Rousseau, J.J. (2003b). Sobre el origen y los fundamentos de la desigualdad entre los hombres. Madrid: Alianza Editorial.

Rousseau, J.J. (2002). Emilo o de la Educación. Madrid: Alianza Editorial.

Ruiz Berrio, J. (1970). Política escolar de España en el siglo XIX. Madrid: CIS.

Rychen, D.S.; Salganik, L.H. (eds.). (2004). Definir y seleccionar las competencias fundamentales para la vida. México: FCE.

Saffange, J.F. (1994). Alexander Sutherland Neill. Perspectives: revue trimestrielle d'éducation comparée, Vol. XXIV, 1-2, pp. 225-236.

Savage, J. (2007). Teenage: The Creation of Routh Culture. London: Randon House.

Schmidt, L. (1990). Jovens: família, dinheiro, autonomia. Análise social, XXV (108109), pp. 645-673.

Schmidt, L. (1989). A Juventude Portuguesa. Situações, Problemas, Aspirações. Vol. 7: Dinheiro e Bens Materiais. Lisboa: Instituto de Ciências Sociais da Universidade de Lisboa.

Schnapp, Alain (1996). La imagen de los jóvenes en la ciudad griega. En Levi, G.; Schmitt, J-C (dirs.). Historia de los jóvenes (Vol I) Madrid: Taurus.

Schindler, N. (1996). Los guardianes del desorden. Rituales de la cultura juvenil en los albores de la era moderna. En G. Levi.; J.C Schmitt (dirs.) Historia de los jóvenes (Vol. I) (pp. 305-353). Madrid: Taurus.

Sennett, R. (2011). El declive del hombre público. Barcelona: Anagrama.

Sennett, R. (2001). La corrosión del carácter. Las consecuencias personales del trabajo en el nuevo capitalismo. Barcelona: Anagrama.

Serrano Pascual, A. (2000). El concepto de empleabilidad en la estrategia europea de lucha contra el desempleo: una perspectiva crítica. Revista del Ministerio de Trabajo y Asuntos Sociales, 21, pp.137-149.

Sérieyx, H. (1994). El Big Bang de las organizaciones. Barcelona: Ediciones B.

Shir-Wise, M. (2018). Disciplined freedom: The productive self and conspicuous busyness in "free" time. Time \& Society, 0 (0), pp. 1-27. 
Shorter, E. (1977). Naissance de la famille moderne. XVIII-XX siècle. París: Éditions du Seuil.

Silva, P.; Pereira, M. (2012). As políticas de proteção no desemprego em Portugal. Sociologia Problemas e Práticas, 70, pp. 133-150.

Simmel, G. (2002). Cuestiones fundamentales de sociología. Barcelona: Gedisa.

Simmel, G. (2001). El individuo y la libertad. En G. Simmel: El individuo y la libertad. Ensayos de crítica de la cultura (pp. 411-424). Barcelona: Paidós.

Singly, F (2016). El yo, la pareja y la familia. Madrid: CIS.

Singly, F. de (2007). Sociologie de la famille contemporaine. París: Armand Colin.

Singly, F. (2005). Las formas de terminar y no terminar la juventud. Revista de Estudios de Juventud, 71, pp. 111-121.

Singly, F. (1995). Elias ou le romantisme éducatif. Sur les tensions dans la éducation contemporaine. Cahiers Intennationaux de Sociologie (1), 99, pp. 279-291.

Smithson, J.; Lewis, S.; Guerreiro, M. (1998). Percepções dos jovens sobre a insegurança no emprego e suas implicações no trabalho e na vida familiar. Sociologia, Problemas e Práticas, 27, pp. 97-113.

Sommerville, Ch. (1982). The rise and fall of Childhood. Beverly Hills: Sage Publications.

Starobinski, J. (1987). L'invention de la liberté. 1700-1789. Genève: Skira.

Starobinski, J. (1983). La transparencia y el obstáculo. Madrid: Taurus.

Steiner, G; Ladjali, C. (2005). Elogio de la transmisión. Maestro y alumno. Madrid: Siruela.

Stone, L. (1990). The Family, Sex and Marriage in England, 1500-1800. London: Penguin Books.

Taylor, Ch. (2006). Imaginarios sociales modernos. Barcelona: Paidós.

Taylor, Ch. (1994). La ética de la autenticidad. Barcelona: Paidós.

Terren, E. (1999). Educación y modernidad. Entre la utopía y la burocracia. Barcelona: Anthropos.

Therborn, G. (1993) Los derechos de los niños desde la constitución del concepto moderno del menor: un estudio comparado de los países occidentales. En L. Moreno (comp.). Intercambio social y desarrollo del bienestar. Madrid: CIS.

Thompson, E.P (1979). Tiempo, disciplina de trabajo y capitalismo industrial. En: E.P Thompson: Tradición, Revuelta y conciencia de clase (pp. 239-293). Barcelona: Critica.

Toharia, J.J. (1989). Los jóvenes españoles ante la familia y el matrimonio. En P. González Blasco (coord.). Jóvenes españoles 89 (pp. 209-233). Madrid: SM. 
Tocqueville (1993). La democracia en América (2 Vols.). Madrid: Alianza Editorial.

Torres Santomé, J. (2008). Obviando el debate sobre la cultura en el sistema educativo: cómo ser competentes sin conocimientos. En J. Gimeno Sacristán: Educar por competencias ¿qué hay de nuevo? (pp. 143-175). Madrid: Morata.

Tort Bardolet, A. (2009). Ivan Illich: La desescolarización o la educación sin escuela. En J. Triilla Bernet: El legado pedagógico del siglo XX para la escuela del siglo XXI (pp 271-296) Barcelona: Graó.

Urraco Solanilla, M.; Nogales Bermejo, G. (2013). Michel Foucault: el funcionamiento de la institución escolar propia de la Modernidad y sus principios rectores. Anduli, 12, pp. 153-168.

Vallés, M.S. (2000). Historia oral de la primera encuesta nacional de juventud. La peripecia humana y política. En A. De Miguel (coord.): Dos generaciones de jóvenes 1960-1998 (113-137). Madrid: Ministerio de Trabajo y Asuntos Sociales.

Varela, J. (2001). Prólogo a Ball, S.J: Foucault y la educación. Disciplinas y saber. Madrid: Morata.

Varela, J. (1992). Categorías espacio temporales y socialización escolar: del individualismo al narcisismo. Revista de Educación, 298, pp. 7-29.

Varela, J-Álvarez-Uría, F (1991). Arqueología de la escuela. Madrid, La Piqueta.

Varela, J. (1991). El triunfo de las pedagogías psicológicas. Cuadernos de Pedagogía, 198, pp. 56-58.

Varela, J. (1984). Modos de educación en la España de la Contrarreforma. Madrid: La Piqueta.

Veira, J.L.; Muñoz, C. (2004). Valores y actitudes del trabajo en Europa Occidental. RES, 4, pp. 51-66.

Velarde, O. (1994). Los valores en torno a la familia y a la sexualidad. En M. Serrano. (dir.). Historia de los cambios de mentalidades de los jóvenes entre 1960-1990 (99-126). Madrid: Injuve.

Vernant, J.P (1985) Mito y pensamiento en la Grecia Antigua. Barcelona: Ariel.

Veyne, Paul (1989). El Imperio romano. En: Ariès, P.; Duby, G: Historia de la vida privada. Madrid. Taurus.

Vincent, G. (1980). Lécole primaire française. Lyon: Presses Universitaires de Lyon.

Vovelle, M. (1985). Ideología y mentalidades. Barcelona: Ariel.

Weber, M. (1998). La ética protestante y el espíritu del capitalismo. En M. Weber: Ensayos sobre sociología de la religión (I). Madrid: Taurus.

Weber, M. (1993). Economía y sociedad. Madrid: FCE.

Willis, P. (1988). Aprendiendo a trabajar. Cómo los chicos de clase obrera consiguen trabajos de clase obrera. Madrid: Akal. 
Wyn, J. y Woodman, D. (2006). Generation, youth and social change in Australia. En Journal of Youth Studies, 9 (5), pp. 495-514.

Zambrano, M. (1992). Persona y democracia. La historia sacrificial. Madrid: Taurus.

Zárraga, J.L (2015). A los 30 años del Informe de Juventud de 1985. Investigación empírica y cuestiones teóricas. Revista de Juventud, 110, pp. 13-33.

Zweig, S. (2005). Erasmo de Rótterdam. Triunfo y tragedia de un humanista. Barcelona: Paidós. 



\section{MANTÉNGASE INFORMADO \\ DE LAS NUEVAS PUBLICACIONES}

Suscríbase gratis

al boletín informativo

www.dykinson.com

$Y$ benefíciese de nuestras ofertas semanales 